\title{
Implementation of Energy Code Controls Requirements in New Commercial Buildings
}

\author{
March 2017 \\ M Rosenberg D Jones \\ R Hart M Cooper \\ M Hatten
}




\title{
DISCLAIMER
}

This report was prepared as an account of work sponsored by an agency of the United States Government. Neither the United States Government nor any agency thereof, nor Battelle Memorial Institute, nor any of their employees, makes any warranty, express or implied, or assumes any legal liability or responsibility for the accuracy, completeness, or usefulness of any information, apparatus, product, or process disclosed, or represents that its use would not infringe privately owned rights. Reference herein to any specific commercial product, process, or service by trade name, trademark, manufacturer, or otherwise does not necessarily constitute or imply its endorsement, recommendation, or favoring by the United States Government or any agency thereof, or Battelle Memorial Institute. The views and opinions of authors expressed herein do not necessarily state or reflect those of the United States Government or any agency thereof.

\author{
PACIFIC NORTHWEST NATIONAL LABORATORY \\ operated by \\ BATTELLE \\ for the \\ UNITED STATES DEPARTMENT OF ENERGY \\ under Contract DE-AC05-76RL01830 \\ Printed in the United States of America \\ Available to DOE and DOE contractors from the \\ Office of Scientific and Technical Information. \\ P.O. Box 62, Oak Ridge, TN 37831-0062; \\ ph: (865) 576-8401 \\ fax: $(865) 576-5728$ \\ email: reports@adonis.osti.gov
}

Available to the public from the National Technical Information Service

5301 Shawnee Rd., Alexandria, VA 22312

ph: (800) 553-NTIS (6847)

email: orders@ntis.gov <http://www.ntis.gov/about/form.aspx>

Online ordering: http://www.ntis.gov

This document was printed on recycled paper.

(8/2010) 


\title{
Implementation of Energy Code Controls Requirements in New Commercial Buildings
}

\author{
M Rosenberg \\ R Hart \\ M Hatten ${ }^{1}$ \\ D Jones ${ }^{2}$ \\ M Cooper $^{2}$
}

March 2017

Prepared for

the U.S. Department of Energy

under Contract DE-AC05-76RL01830

Pacific Northwest National Laboratory

Richland, Washington 99352

\footnotetext{
${ }^{1}$ Solarc Energy Group, LLC

${ }^{2}$ Group14 Engineering, Incorporated
} 


\section{Executive Summary}

The U.S. Department of Energy Building Energy Codes Program supports the development and implementation of building energy codes and standards (DOE 2015). This support includes providing resources and tools to assist states in evaluating compliance with building energy codes. The research described in this report was conducted by Pacific Northwest National Laboratory (PNNL) and expands on previous work in this area.

The objective of the current research is to evaluate the degree to which high-impact energy code controls requirements are properly designed, commissioned, and implemented in new buildings and how well they provide energy cost savings. This study used a three-step process: (1) interviews of commissioning agents; (2) field audits of a sample of commercial buildings to determine how well control measures are being designed, commissioned and correctly implemented; and (3) analysis of the information gathered. The results will be valuable to code developers, energy planners, designers, building owners, and building officials.

\section{Controls Requirements in Energy Codes}

Most state energy codes are based on model codes; either ANSI/ASHRAE/IES ${ }^{1} 90.1$ (Standard 90.1) or the International Code Council (ICC) International Energy Conservation Code (IECC). Since 2004, about $30 \%$ of all new requirements have been related to building controls. These control requirements can be difficult to implement and verification is beyond the expertise of most building code officials, yet the assumption is that they are implemented and working correctly.

Commercial energy codes specify component efficiencies such as the R-value of insulation, maximum lighting power, and air conditioner efficiency. In addition, the code also includes requirements applicable to building control. Most apply to building heating, ventilation, and air-conditioning (HVAC) and lighting systems. PNNL reviewed the most recent editions of Standard 90.1 (90.1-2013) and the IECC (2015) and identified 90 individual requirements related to building controls (ASHRAE 2013, ICC 2015). The 90 requirements were grouped into 51 "measures" containing related requirements. Appendix A lists the 51 control measures and their related requirements.

A team of six experts ranked the 51 measures. The experts were all knowledgeable in both building controls and energy code requirements. They independently provided scores for each measure on a 1 to 5 scale (with 5 being the highest) for the following criteria: applicability in buildings, energy impact of noncompliance, and likelihood of non-compliance.

Based on the measure rankings, the 14 most impactful measures were selected for evaluation, with 10 HVAC measures: (1) controls for thermostat deadband, (2) economizer, (3) variable air volume box minimum, 4) off hour temperature setback, (5) outdoor air dampers, (6) supply air temperature reset, (7) zone isolation, (8) demand controlled ventilation, (9) fan static pressure reset, and (10) optimum start; and four lighting measures: (1) occupancy sensors, (2) daylighting, (3) exterior lighting controls, and (4) lighting time switches. Those measures and their abbreviations used throughout this report are listed in

\footnotetext{
${ }^{1}$ American National Standards Institute/American Society of Heating, Refrigerating, and Air Conditioning Engineers/Illuminating Engineering Society
} 
Table 5. Details of the associated requirements are provided in Appendix A.

Both Standard 90.1 and the IECC regulate the design and construction of buildings, but not the ongoing operation of those buildings. The energy code compliance process typically ends once a jurisdiction issues a certificate of occupancy. Controls however, could be considered operational, presenting what could be construed as a conflict. To address this, many controls requirements are expressed as capabilities instead of operational instructions; however, in other cases, the requirements are expressed as operational instructions. The research described in this report assumes that at least at the time of inspection, the system must be configured to operate as specified in the code. Therefore compliance is evaluated from three perspectives: 1 ) how well the requirement is included in design documents (design), 2) the capability of the installed components to achieve the code described controls sequence (capability), and 3) how the building controls are configured (configuration).

\section{Project Approach}

Once the 14 most impactful controls requirements were identified, a three-step approach was taken to determine the degree to which these requirements are designed, commissioned and correctly implemented in new buildings. The three steps, Commissioning Agent Surveys, Field Assessments, and Results Analysis, are described below.

Commissioning Agent Surveys. As building commissioning is required in both model energy codes and commissioning verifies proper control operation, 10 experienced commissioning agents were surveyed to better understand the relationship of commissioning to energy code controls requirements. The surveys covered the commissioning agents' responsibilities in verifying code compliance, their activities related to design review and testing, and their judgment about the quality of design specifications and controls implementation.

Field Assessments. To assess actual design and operation of the impactful lighting and HVAC system controls requirements, onsite audits and design document evaluations of newly constructed nonresidential buildings were conducted in six states representing three climate zones. Twenty-four buildings in the Pacific Northwest and Mountain regions, ranging in size from 10,300 to 242,500 $\mathrm{ft}^{2}$ with a median size of 70,000 $\mathrm{ft}^{2}$ were evaluated. They included office, medical, retail, and educational occupancies. Details are included in Table 5. The field assessors were asked to score each applicable control measure in each building for each of the three compliance perspectives previously described: design, capability, and configuration. The field assessment evaluated these buildings as close to occupancy as possible so that observed field conditions approximate their state at the time a certificate of occupancy was granted.

Results Analysis. Once the scoring of measures by building was completed the results were analyzed to determine the statistical validity of findings in the sample. Analysis addressed group results for HVAC, lighting, and overall measures, and differences in scores from the perspective of design, capability, and actual configuration. Commissioning agent opinions about measure compliance were compared with actual field results. 


\section{Results}

\section{Commissioning Agent Survey Results}

Six of ten commissioning agents interviewed did not feel that verifying code compliance was implicitly part of the scope of their work, and half of them indicated that they did not review the design for nor test functionality of energy code-required measures. None of the commissioning agents thought design documents always adequately specified controls requirements.

Commissioning agents were familiar with most of the control measures and gave fairly high grades to questions about the actual final configuration of the individual measures. They reported a substantial improvement from initial to final testing indicating that commissioning has a positive impact on control requirement compliance. They estimated that $88 \%$ of the 14 high-impact control strategies are capable of operating in compliance with code requirements and $79 \%$ are configured that way at the completion of commissioning. However based on other responses about scope of commissioning services, inadequacy of design documents, and limited functional testing, that estimate may be unrealistic. Figure ES1 summarizes the responses to the specific questions about the 14 high-impact code requirements. Measure specific responses are included in Section 3.2.2.

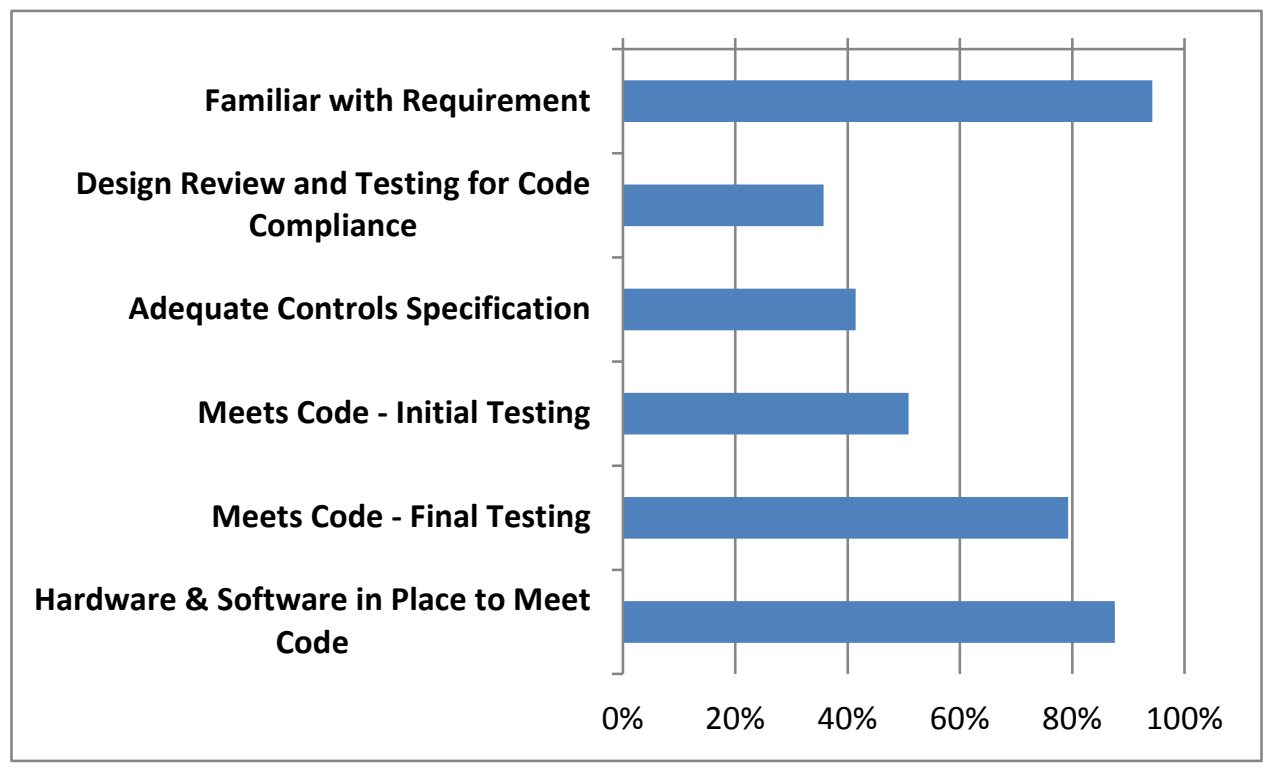

Figure ES1. Commissioning Agent Responses - Combined for all Measures

\section{Field Assessment Results}

Based on design document review and field assessment, each of the 14 high-impact control measures were scored for design, capability, and configuration with regard to how they match the code requirements. A score of zero indicated complete non-compliance and a score of 10 was fully compliant or exceeded compliance. Scoring between those two extremes was dependent on the particular measure and is described in Section 4.1. 
Overall compliance findings are summarized in Figure ES2. The capability of HVAC controls are slightly more code compliant than that of lighting. However, design and actual operating conditions associated with lighting controls tend to be slightly more compliant than HVAC. Overall, capability of controls scored highest indicating the potential to intervene with operating buildings to improve compliance (and reduce energy use). Overall, design and configuration score at about the same level. On a measure-by-measure basis, $60 \%$ were compliant, $40 \%$ were partially non-compliant, and $12 \%$ were not compliant.

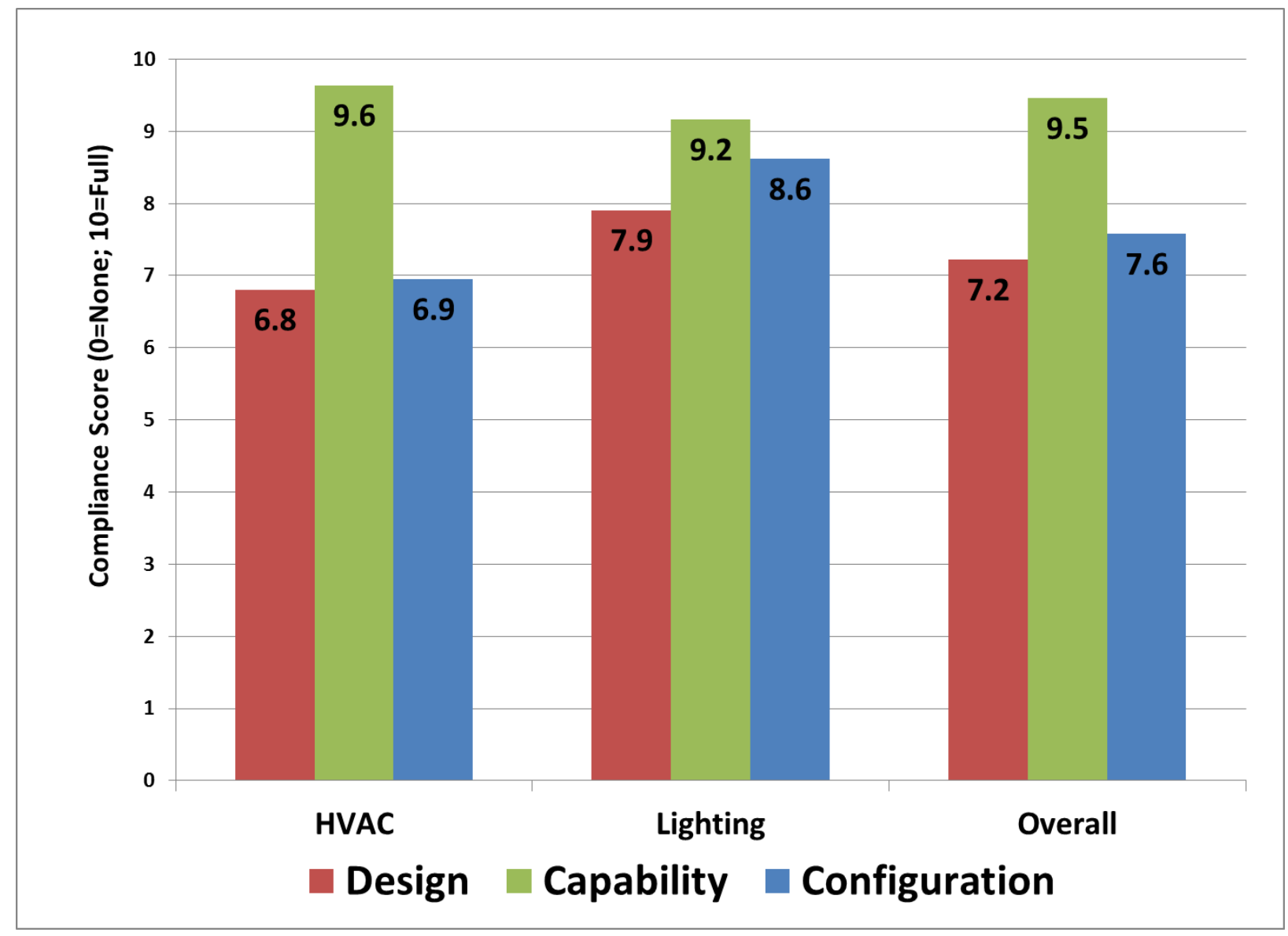

Figure ES2. Average Scores by Control Type and Perspective

\section{Analysis of Field Results}

The differences between scores for measures based on the three perspectives are shown in Figure ES2. When all control measures are included the design and configuration perspective scores were found to be significantly equivalent. The difference between capability and the other perspectives was found to be significantly different when the entire measure group is considered.

The measures exhibiting the poorest design compliance are (1) optimal start, (2) automatic dampers, (3) thermostat deadband, and (4) thermostatic setback. Measures with the poorest configuration include (1) optimal start, (2) automatic dampers, 3) thermostat setback, and (4) daylighting controls. These measure score differences were all found to be statistically significant. All measures showed good 
capability (8.4 or greater). Demand controlled ventilation was complied with for all three perspectives in every building where applicable.

While the field work focused on comparison of scores for design, capability, and configuration of control measures, also of interest is the energy cost impact of the variation between how these buildings are being operated and the code specifications. To determine that, results from related research were used to develop a rough indicator of overall lost energy cost savings (Rosenberg et al. 2016, Fernandez et al. 2012). Final configuration scores were used to develop lost energy savings estimates. Details of how the previous research was used to assign lost cost savings is discussed in Section 5.4, including a number of caveats that need to be considered when using these results. Annual lost cost savings were calculated on a per measure basis, a per building basis, for the entire sample, and per thousand square feet of conditioned floor area. Table ES1 summarizes the lost energy cost savings by measure category. Lost cost savings for each of the 14 measures are presented in Section 5.4.1.

Table ES1. Summary of Lost Energy Cost Savings

\begin{tabular}{|c|c|c|c|}
\hline Measure Category & $\begin{array}{c}\text { Lost Savings Total } \\
\text { Sample (\$/yr) }\end{array}$ & $\begin{array}{l}\text { Lost Savings per } \\
\text { Building (\$/yr) }\end{array}$ & $\begin{array}{c}\text { Lost Savings } \\
\left.\text { (\$/thousand } \mathbf{f t}^{2}-\mathbf{y r}\right)\end{array}$ \\
\hline HVAC & $\$ 288,588$ & $\$ 12,025$ & $\$ 161$ \\
\hline Lighting & $\$ 13,684$ & $\$ 570$ & $\$ 8$ \\
\hline Overall & $\$ 302,272$ & $\$ 12,595$ & $\$ 168$ \\
\hline
\end{tabular}

Based on compliance scores, we previously identified the measures that exhibit the poorest compliance for design, capability, and configuration to help focus efforts for training, education, outreach, etc., where it can do the most good. However, even more important in determining where to commit these resources is the lost energy cost savings associated with sub-standard compliance. Those measures with the highest lost energy cost savings are (1) automatic dampers, (2) thermostat setback, (3) simultaneous heating and cooling, (4) economizer integration, and (5) optimal start.

The potential recovered lost energy cost savings through better compliance with the 14 impactful control measures is substantial at $\$ 168 /$ thousand $\mathrm{ft}^{2}$-yr, or $\$ 2,122 /$ thousand $\mathrm{ft}^{2}$ over the life of the control measures. To put that into perspective, the nationally weighted average energy cost for new buildings constructed to Standard 90.1-2010 (similar to the base code under which most of these buildings were constructed) is approximately $\$ 1,420 /$ thousand $\mathrm{ft}^{2}$-yr, (Zhang et al. 2014). This indicates that approximately $12 \%$ of total building energy cost could be saved through better compliance with these measures.

Although the sample size is relatively small (24 buildings) there are a number of statistically valid inferences that can be made from the results of the current research. The major conclusions are summarized here with the detailed results presented in Sections 4.0 and 5.0.

- Overall, controls as implemented have the capability to meet energy codes specifications with an average score of 9.5 out of 10; however, actual configuration has an average score of only 7.6 with only $50 \%$ achieving fully compliant configuration.

- For the five measures where commissioning had at least marginally significant impact, the result was always an improvement in energy savings; however, the sample size was too small to verify the impact of commissioning on most measures. 
- The study found several measures to have significantly lower scores than the whole group and several that had a higher impact on lost energy cost.

- On an individual control measure basis, most measures had a capability compliance score significantly higher than both scores based on design details and actual configuration.

- On an individual control measure basis, five measures had a configured condition that was significantly higher than the design score. 


\section{Acknowledgments}

This report was prepared by Pacific Northwest National Laboratory (PNNL) for the U.S. Department of Energy (DOE) Building Energy Codes Program. The authors would like to thank the following people:

- David Cohan at DOE for providing insight

- Bing Liu, Manager, Building Energy Codes Program, PNNL

Michael Rosenberg

Pacific Northwest National Laboratory 



\section{Acronyms and Abbreviations}

$\begin{array}{ll}\text { AHU } & \text { air handling unit } \\ \text { ANSI } & \text { American National Standards Institute } \\ \text { ASHRAE } & \text { American Society of Heating, Refrigerating and Air-Conditioning Engineers } \\ \text { AHJ } & \text { Authority Having Jurisdiction } \\ \text { BECP } & \text { Building Energy Codes Program } \\ \text { Cx } & \text { commissioning } \\ \text { CxA } & \text { commissioning agent } \\ \text { DCV } & \text { demand controlled ventilation } \\ \text { DDC } & \text { direct digital control } \\ \text { DOAS } & \text { dedicated outdoor air system } \\ \text { DOE } & \text { U.S. Department of Energy } \\ \text { DX } & \text { direct expansion } \\ \text { F } & \text { Fahrenheit } \\ \text { HP } & \text { heat pump } \\ \text { HVAC } & \text { heating, ventilation, and air conditioning } \\ \text { ICC } & \text { International Code Council } \\ \text { IES } & \text { Illuminating Engineering Society } \\ \text { IECC } & \text { International Energy Conservation Code } \\ \text { LEED } & \text { Leadership in Energy and Environmental Design } \\ \text { MTN } & \text { mountain } \\ \text { PNNL } & \text { Pacific Northwest National Laboratory } \\ \text { PNW } & \text { Pacific Northwest } \\ \text { SHGC } & \text { solar heat gain coefficient } \\ \text { VAV } & \text { variable air volume } \\ \text { VRF } & \text { variable refrigerant flow } \\ \text { WSHP } & \text { water source heat pump } \\ & \\ \text { DE } & \end{array}$




\section{Contents}

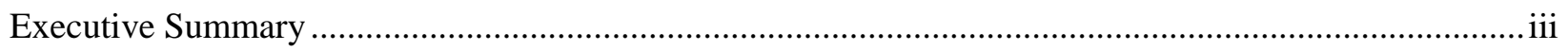

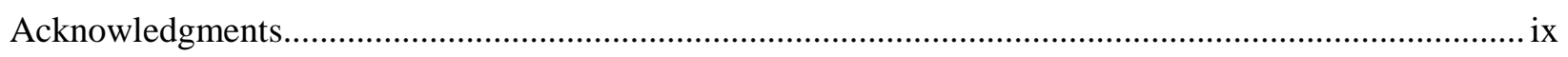

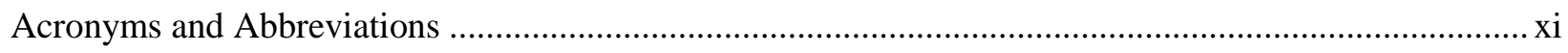

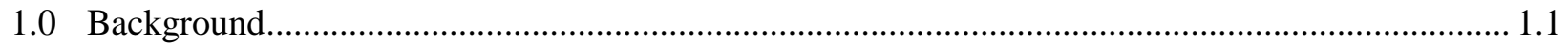

1.1 Controls Requirements in Energy Codes .................................................................... 1.1

1.1.1 Design Requirements versus Operational Requirements .......................................... 1.2

1.2 Commissioning Requirements in Energy Codes ................................................................ 1.3

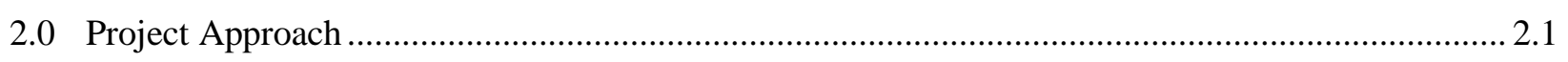

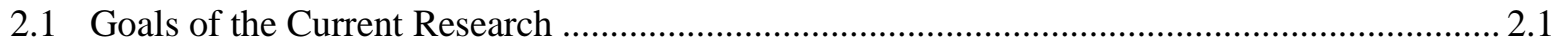

2.2 Fundamental Approach and Scope................................................................................ 2.1

2.2.1 Identification of High-Impact Controls Requirements.............................................. 2.1

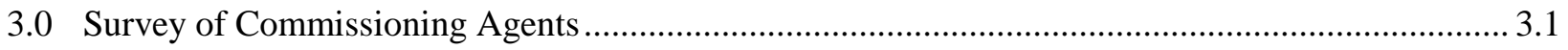

3.1 Recruitment of Commissioning Agents ........................................................................... 3.1

3.2 Results of Survey of Commissioning Agents................................................................... 3.1

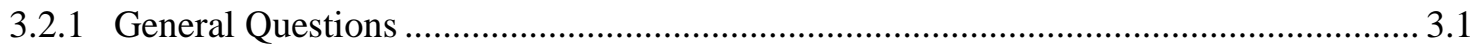

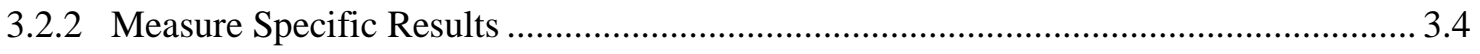

3.2.3 Individual Measure Results and Comments ................................................................ 3.6

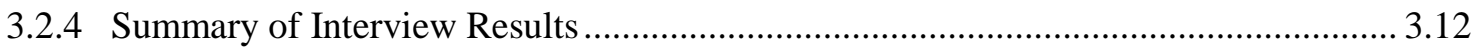

4.0 Field Assessment of Implementation of Controls Requirements …............................................. 4.1

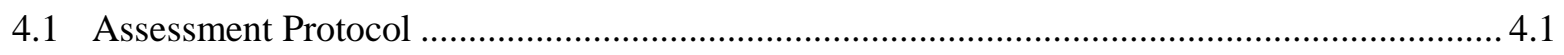

Measure 1: Set Point Overlap Restriction ........................................................................... 4.2

Measure 2: Economizer Integration and High Limit............................................................. 4.2

Measure 3: Off-Hour Automatic Setback Control .............................................................. 4.3

Measure 4: Limits on Simultaneous Heating and Cooling..................................................... 4.3

Measure 5: Automatic Outdoor Air Dampers ........................................................................... 4.3

Measure 6: Supply Air Temperature Reset ..................................................................... 4.3

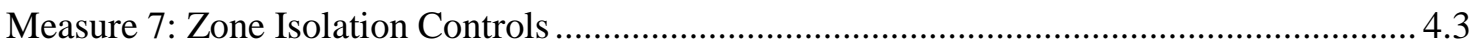

Measure 8: Demand Controlled Ventilation ............................................................................ 4.4

Measure 9: Fan Static Pressure Reset............................................................................. 4.4

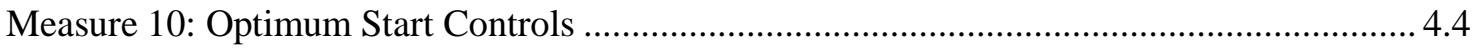

Measure 11: Occupant-Based Interior Light Controls ............................................................... 4.4

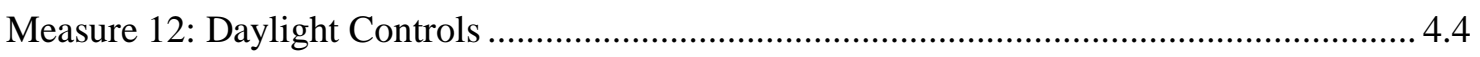

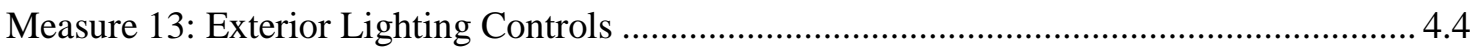

Measure 14: Timer-Based Interior Lighting Controls............................................................ 4.4

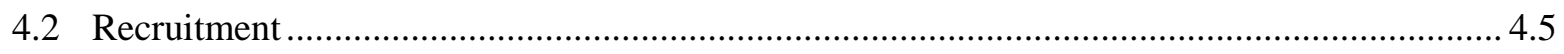

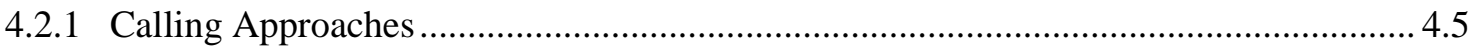




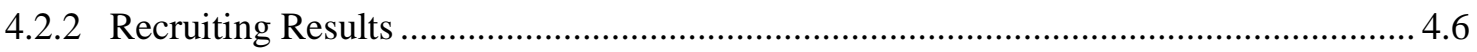

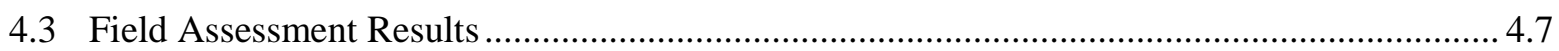

4.3.1 Individual Building Field Results................................................................................... 4.11

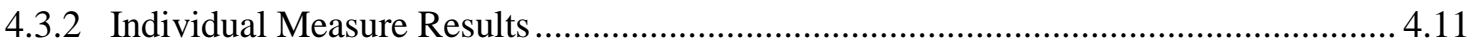

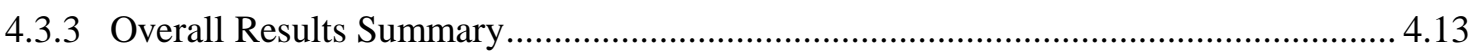

5.0 Analysis of Results and Impact of Controls Implementation ........................................................ 5.1

5.1 Overall Performance of Energy Saving Controls ................................................................ 5.1

5.1.1 Overall Controls Energy Code Compliance............................................................... 5.2

5.1.2 Statistical Validation of Compliance Results ................................................................ 5.3

5.1.3 Code Compliance of Control Measures ..................................................................... 5.4

5.1.4 Measure-by-Measure Compliance Discussion ............................................................. 5.5

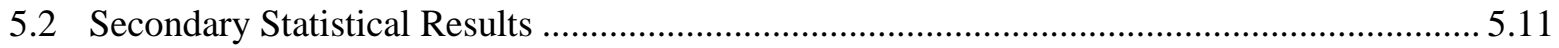

5.2.1 Relationships of Perspectives and Time Lag............................................................ 5.11

5.2.2 Overall Relationship between Perspectives ................................................................. 5.12

5.2.3 Control Measures Compliance Variation by Perspective.............................................. 5.13

5.2.4 The Impact of Time Lag on Configured Results....................................................... 5.14

5.2.5 Geographic Impact on Compliance Scores ............................................................. 5.14

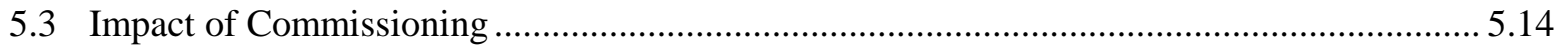

5.3.1 Overall Impact of Lighting and HVAC Commissioning …...................................... 5.14

5.3.2 Measure Level Impact of Commissioning .............................................................. 5.15

5.3.3 Commissioning Agent Opinion Comparison ............................................................ 5.15

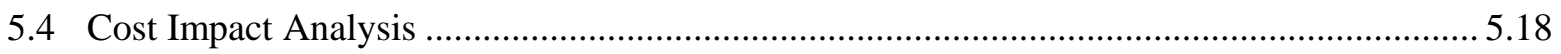

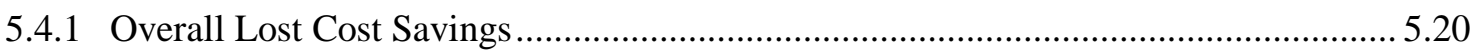

5.4.2 Control Measure Impact on Lost Cost Savings............................................................ 5.21

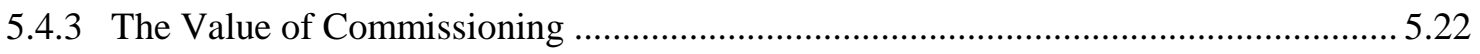

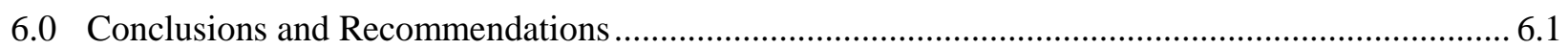

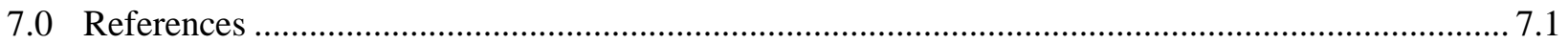

Appendix A Controls Requirements in ASHRAE Standard 90.1-2013 and the 2015 IECC................... A.1

Appendix B Commissioning Agent Interview Responses ...................................................................... 1

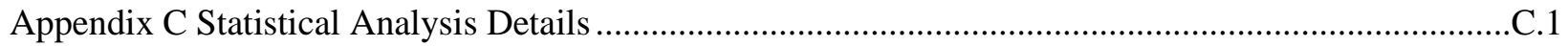





\section{Figures}

Figure 1. Commissioning Agent Responses to Questions 1 through 4 ................................................... 3.3

Figure 2. Question 5 - Greatest Impediments to Successful Implementation of Code-Required

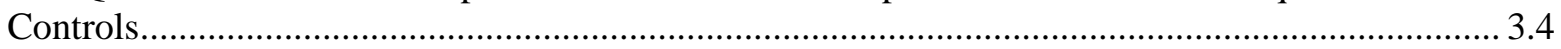

Figure 3. Commissioning Agent Responses - Combined for all Measures............................................. 3.6

Figure 4. Commissioning Agent Responses to Measure Specific Questions ......................................... 3.11

Figure 5. Average Compliance Score by Building ............................................................................ 4.11

Figure 6. Average Compliance Score by Measure......................................................................... 4.12

Figure 7. Average Compliance Scores by Control Type and Perspective ............................................ 4.13

Figure 8. HVAC Compliance Score Distribution ............................................................................... 4.15

Figure 9. Lighting Compliance Score Distribution............................................................................. 4.16

Figure 10. Overall Compliance Score Distribution.............................................................................. 4.17

Figure 11. Field Observations by Compliance Category - By Control Type and Perspective.................. 5.2

Figure 12. Partial Score Distribution, Excluding Absent (score =0) and Full Compliant (score = 10)

Figure 13. Comparison of Commissioning Agent Opinion to Field Conditions 



\section{Tables}

Table 1. Control Measures in Standard 90.1-2013 and the 2015 IECC.................................................. 1.2

Table 2. Code Control Measure Scores and Ranking ........................................................................ 2.2

Table 3. Distribution of Buildings Successfully Recruited..................................................................... 4.6

Table 4. Summary of Successfully Recruited Buildings ........................................................................ 4.6

Table 5. Abbreviations for Control Measures.................................................................................... 4.8

Table 6. Compliance Scores for all Measures and Buildings ................................................................. 4.9

Table 7. Meaning of p-value and Levels of Significance and Certainty .................................................. 5.4

Table 8. Measure Compliance Scores and Statistical Significance ${ }^{\dagger}$..................................................... 5.5

Table 9. Difference in Perspective Average Compliance Scores............................................................ 5.12

Table 10. Overall Commissioning Impact, Kruskal-Wallis Multiple Comparison Test ${ }^{\dagger}$........................ 5.15

Table 11. Annual Lost Energy Cost Savings and Source ................................................................ 5.19

Table 12. Lost Energy Cost Savings Overall and by Building ........................................................... 5.21

Table 13. Lost Energy Cost Savings by Measure ….............................................................................. 5.22 


\subsection{Background}

The U.S. Department of Energy (DOE) Building Energy Codes Program (BECP) supports the development and implementation of building energy codes and standards (DOE 2015). This includes providing technical assistance to states to implement building energy codes, including increasing and verifying compliance to ensure consumer benefits. When commercial energy code compliance is improved, businesses save money on energy bills that can be invested in other business activities or job generation. One key area in which BECP has worked over the past several years is providing resources and tools to assist states in evaluating compliance with building energy codes. The research described in this report was conducted by Pacific Northwest National Laboratory (PNNL) and expands on previous work in this area.

Most state energy codes in the United States are based on one of two national model codes: ANSI/ASHRAE/IES ${ }^{1} 90.1$ (Standard 90.1) or the International Energy Conservation Code (IECC). Since 2004, covering the last four cycles of Standard 90.1 updates, about $30 \%$ of all new requirements have been related to building controls. These requirements can be difficult to implement and verification is beyond the expertise of almost any building code official, yet the assumption in studies that measure the savings from energy codes is that they are implemented and working correctly (PNNL 2010). This study used a three-step process to evaluate the degree to which high-impact controls requirements included in commercial energy codes are realizing their savings potential. The first step involved interviewing commissioning agents to get a better understanding of their activities as they relate to energy coderequired controls measures. The second step involved field audits of a sample of commercial buildings to determine whether the code-required control measures are being designed, commissioned, and correctly implemented and functioning in new buildings. The third step involved analysis of the significance of the results. The results of these activities will be valuable to building owners and tenants, business owners, code developers, energy planners, designers, and building officials.

\subsection{Controls Requirements in Energy Codes}

Commercial energy codes specify component efficiencies such as the R-value of insulation, maximum lighting power, boiler thermal efficiency, and air conditioner energy efficiency ratio. In addition to component efficiency requirements, the code also includes requirements applicable to building control and the components necessary to achieve the specified control. Most of these control requirements apply to building heating, ventilation, and air conditioning (HVAC) and lighting systems. For example, commercial energy codes require that thermostatic controls include a deadband, or offset, between the heating and cooling setpoints so zones do not quickly switch between heating and cooling, thus wasting energy. Another common example is exterior lighting that requires controls to prevent the lights from being energized during the day.

PNNL reviewed the most recent editions of Standard 90.1 (90.1-2013) and the IECC (2015) and identified 90 individual requirements related to building controls (ASHRAE 2013, ICC 2015). Next, the 90 requirements were grouped into 51 "measures" containing related requirements. For example, the economizer control measure includes requirements for economizer high limit control, economizer control signal, economizer impact on heating, and economizer integration with mechanical cooling. These four requirements were grouped into a single measure called "economizer integration and high limit control."

\footnotetext{
${ }^{1}$ American National Standards Institute/American Society of Heating, Refrigerating, and Air Conditioning Engineers/Illuminating Engineering Society
} 
Table 1 lists the 51 control measures in Standard 90.1-2013 and the 2015 IECC. Table A.1 in Appendix A lists both the 51 measures and the 90 associated requirements.

Table 1. Control Measures in Standard 90.1-2013 and the 2015 IECC

\begin{tabular}{l|l}
\hline $\begin{array}{l}\text { Five degree thermostat deadband and setpoint overlap } \\
\text { prevention }\end{array}$ & Snow melt system control \\
\hline Occupant-based interior lighting controls & Heat-pump supplemental heat lockout \\
\hline Economizer integration and high limit controls & Kitchen demand ventilation controls \\
\hline $\begin{array}{l}\text { Off-hour automatic temperature setback and system } \\
\text { shutoff with manual override }\end{array}$ & Variable-flow hydronic system controls \\
\hline Limits on simultaneous heating and cooling - airside & Energy recovery economizer bypass \\
\hline $\begin{array}{l}\text { Variable air volume (VAV) dynamic ventilation } \\
\text { optimization }\end{array}$ & $\begin{array}{l}\text { Parking garage carbon monoxide control of ventilation } \\
\text { fans }\end{array}$ \\
\hline Automatic outdoor air damper controls & SWH restroom outlet maximum temperature controls \\
\hline Supply air temperature reset - reheat systems & Elevator standby lighting and ventilation controls \\
\hline $\begin{array}{l}\text { Daylighting controls implemented correctly when } \\
\text { required }\end{array}$ & Limits on simultaneous heating and cooling - water-side \\
\hline Fan variable airflow control & Refrigeration system condenser controls \\
\hline Zone isolation controls & Boiler temperature reset \\
\hline Demand controlled ventilation & Parking garage lighting controls \\
\hline One thermostat or other temperature controller per zone & Laboratory exhaust hood flow control \\
\hline Exterior lighting controls & Refrigeration system compressor controls \\
\hline Fan static pressure reset controls & HW and CW temperature reset controls \\
\hline Occupant-based receptacle control & Walk-in cooler and freezer controls \\
\hline Timer-based interior lighting controls & Heat rejection fan variable-flow controls \\
\hline Open door lockout of HVAC & Refrigerated display case controls \\
\hline Dual setpoint or manual mode thermostat & SWH pressure booster pump control \\
\hline Vestibule heating controls & Air curtain controls for velocity and maximum velocity \\
\hline Optimum start controls & WLHP loop flow controls \\
\hline SWH storage temperature controls & WLHP loop temperature deadband controls \\
\hline Economizer heating impact limitation & Control of dynamic glazing \\
\hline SWH circulation loop controls & WLHP loop heat rejection controls \\
\hline Humidity control limitations & Escalator and moving walkway demand control \\
\hline Fractional HP fan motor speed controls & \\
\hline & \\
\hline
\end{tabular}

\subsubsection{Design Requirements versus Operational Requirements}

Both Standard 90.1 and the IECC regulate the design and construction of buildings, but not building operation; the energy code compliance process typically ends once a jurisdiction issues a certificate of occupancy. Controls, however, could be considered operational, presenting what could be construed as a conflict. To address this, many controls requirements are expressed as capabilities instead of operational instructions. For example, Standard 90.1 includes a requirement that “... stair and elevator shaft vents shall be equipped with motorized dampers that are capable of being automatically closed during normal building operation and are interlocked to open as required by fire and smoke detection systems." However, some requirements appear to present operational instructions. For example, Standard 90.1 contains this requirement for elevators: “... when stopped and unoccupied with doors closed for over 15 minutes, cab interior lighting and ventilation shall be de-energized until required for operation.”

There are two ways to interpret whether these types of requirements comply with the code. The first is that the building complies with the requirement if it includes all the hardware and software necessary to implement the control regardless of whether or not it performs the specified operation. Using the stair and shaft vent example above, if the building included automatic dampers on the vents and the controls 
included a mode that would keep them closed during occupancy, and opened them as required for emergency, the system would comply even if the control system was configured to keep the vents open during occupied hours. The second is that at least at the time of inspection, the system must be configured to operate as specified with the dampers closed during occupancy. Changes included in the 2016 edition of Standard 90.1 clarify that controls must be both capable of and configured to the requirements in the standard. ${ }^{1}$ This study evaluates compliance from three perspectives: (1) how well the requirement is included in design documents (Design), (2) the capability of the installed components to achieve the code described controls sequence (Capability), and (3) how the building controls are actually configured at the time of field inspection (Configuration).

\subsection{Commissioning Requirements in Energy Codes}

Commissioning is an activity intended to verify that the building systems match the owner's requirements and design intent, including energy code requirements if they are specified in the design. Some commissioning requirements are included in the energy codes, especially related to lighting and HVAC control sequences. The comparison of commissioning requirements in Standard 90.1-2013 and the 2015 IECC is summarized below:

- The IECC is much more explicit in how commissioning is to be reported (a preliminary and final report) and how the code official is to be notified.

- Both Standard 90.1 and the IECC have very similar requirements for lighting controls including functional testing covering timers, occupancy sensors, and daylight responsive controls. Both require documentation that the lighting controls specifically meet the energy code requirements.

- For HVAC controls, the IECC requires that for buildings with cooling capacity $\geq 40$ tons or total heating and hot water capacity $\geq 600 \mathrm{MBH},{ }^{2}$ the registered design professional is to designate what and how equipment shall be tested; however, there is no specific requirement that all energy coderequired controls be included. Standard 90.1 requires that all control systems be tested and requires detailed instructions for commissioning when buildings are larger than 50,000 square feet; however, there is no specific list of items to test or any reference to specific energy code control requirements.

- Neither the IECC nor Standard 90.1 requires that the commissioning agent be independent from the design team, nor that commissioning occur concurrently with the design phase of the building. Green rating systems including Leadership in Energy and Environmental Design (LEED) often give additional credit for including commissioning during the design phase (USGBC 2014). This can allow the commissioning agent to review control sequences for energy efficiency or code compliance if that is part of their scope.

\footnotetext{
${ }^{1}$ Addendum AV to Standard 90.1-2013 added the phrase "and be configured to" after the phrase "capable of" where appropriate throughout the Standard.

${ }^{2} \mathrm{An} \mathrm{MBH}$ is $1000 \mathrm{BTU} / \mathrm{hr}$.
} 


\subsection{Project Approach}

\subsection{Goals of the Current Research}

Because of the complexity of control requirements and the ambiguity surrounding what exactly is required, many compliance studies have also tended to ignore them. For codes to progress toward net zero energy new construction by 2030 - which has been a stated goal of many stakeholders in the buildings industry - those requirements will need to be properly implemented (ASHRAE 2008, Architecture 2030 2011). The objective of the current research is to evaluate the degree to which high-impact controls requirements included in commercial energy codes are properly designed, commissioned and implemented in new buildings. Where the evaluation shows less-than-acceptable rates of implementation, recommendations are provided on strategies that will help improve compliance to achieve the maximum savings.

\subsection{Fundamental Approach and Scope}

The approach to determining the degree to which high-impact controls requirements included in commercial energy codes are designed, commissioned and correctly implemented in new buildings involved the following steps.

- Identification of high-impact controls requirements

- Survey of commissioning agents

- Field assessment of the implementation of control requirements

- Analysis of results

\subsubsection{Identification of High-Impact Controls Requirements}

To identify the most impactful of the 51 controls measures, a team of six experts was engaged to rank them. The experts were all knowledgeable in both building controls and energy code requirements. They independently provided scores for each measure on a one-to-five scale (with 5 being the highest) for each of the following criteria.

- Applicability in buildings: How common is this requirement found in the new construction building stock?

- Energy impact of no compliance: Rating of potential negative energy impact (lost savings) if the measure is not complied with.

- Likelihood of non-compliance: Where the measure is required, how likely is it to be incorrectly implemented or not implemented at all?

Table 2 shows the sum of the scores for each measure from each category and ranks the measures based on the scores from highest to lowest. Given limited project resources, it was determined that the top 14 ranked measures could be evaluated in the field. However, four of the measures were eliminated from consideration because they were only introduced into the codes during the most recent publication (2015 IECC or Standard 90.1-2013). Since only seven states have adopted one of those new versions, most newly constructed buildings verified in the field will have been built under a previous edition of the code (DOE 2016). After eliminating those four measures, the next four in the ranking were added. The 14 measures selected for the current study are highlighted in Table 2. 
Table 2. Code Control Measure Scores and Ranking

\begin{tabular}{|c|c|c|c|c|c|}
\hline & \multirow[b]{2}{*}{ Control Measure } & \multicolumn{3}{|c|}{ Sum of Six Raters' Scoring } & \multirow[b]{2}{*}{$\begin{array}{l}\text { Total } \\
\text { Score }\end{array}$} \\
\hline & & $\begin{array}{c}\text { Energy Impact } \\
\text { of Non- } \\
\text { Compliance } \\
\end{array}$ & $\begin{array}{c}\text { Likelihood of } \\
\text { Non- } \\
\text { Compliance } \\
\end{array}$ & $\begin{array}{l}\text { Applicability } \\
\text { in Buildings }\end{array}$ & \\
\hline 1 & $5^{\circ}$ thermostat deadband/setpoint overlap prevention* & 19 & 22 & 30 & 71 \\
\hline 2 & Occupant-based interior lighting controls* & 24 & 16 & 29 & 69 \\
\hline 3 & Economizer integration and high limit controls* & 23 & 17 & 26 & 66 \\
\hline 4 & Off-hour auto temp setback and shutoff with override* & 20 & 15 & 30 & 65 \\
\hline 5 & Automatic outdoor air damper controls* & 19 & 18 & 27 & 64 \\
\hline 6 & VAV dynamic ventilation optimization** & 19 & 24 & 21 & 64 \\
\hline 7 & Limits on simultaneous heating and cooling - airside* & 23 & 19 & 22 & 64 \\
\hline 8 & Supply air temperature reset - reheat systems* & 22 & 20 & 21 & 63 \\
\hline 9 & Daylighting controls implemented when required* & 19 & 23 & 21 & 63 \\
\hline 10 & Fan variable airflow control** & 22 & 17 & 22 & 61 \\
\hline 11 & Demand controlled ventilation* & 20 & 17 & 22 & 59 \\
\hline 12 & Zone isolation controls* & 17 & 19 & 23 & 59 \\
\hline 13 & Exterior lighting controls* & 16 & 15 & 27 & 58 \\
\hline 14 & Timer-based interior lighting controls* & 19 & 13 & 25 & 57 \\
\hline 15 & Occupant-based receptacle control* & 13 & 20 & 24 & 57 \\
\hline 16 & Fan static pressure reset controls & 17 & 18 & 22 & 57 \\
\hline 17 & Open door lockout of HVAC** & 17 & 21 & 18 & 56 \\
\hline 18 & Optimum start controls* & 12 & 17 & 26 & 55 \\
\hline 19 & Vestibule heating controls** & 13 & 22 & 20 & 55 \\
\hline 20 & Dual setpoint or manual mode thermostat & 16 & 15 & 24 & 55 \\
\hline 21 & One thermostat or other controller per zone & 15 & 10 & 29 & 54 \\
\hline 22 & SWH storage temperature controls & 13 & 15 & 25 & 53 \\
\hline 23 & Economizer heating impact limitation & 18 & 13 & 21 & 52 \\
\hline 24 & SWH circulation loop controls & 12 & 16 & 22 & 50 \\
\hline 25 & Snow melt system control & 23 & 18 & 8 & 49 \\
\hline 26 & Fractional HP fan motor speed controls & 14 & 16 & 19 & 49 \\
\hline 27 & Humidity control limitations & 18 & 16 & 15 & 49 \\
\hline 28 & Variable flow hydronic system controls & 16 & 14 & 18 & 48 \\
\hline 29 & Kitchen demand ventilation controls & 20 & 17 & 11 & 48 \\
\hline 30 & Heat pump supplemental heat lockout & 18 & 17 & 13 & 48 \\
\hline 31 & Energy recovery economizer bypass & 15 & 13 & 19 & 47 \\
\hline 32 & SWH restroom outlet maximum temperature controls & 8 & 12 & 26 & 46 \\
\hline 33 & Parking garage CO control of ventilation fans & 20 & 15 & 11 & 46 \\
\hline 34 & $\begin{array}{l}\text { Limit on simultaneous heating and cooling - water- } \\
\text { side }\end{array}$ & 19 & 12 & 14 & 45 \\
\hline 35 & Elevator standby lighting and ventilation controls & 12 & 16 & 17 & 45 \\
\hline 36 & Laboratory exhaust hood flow control & 21 & 13 & 9 & 43 \\
\hline 37 & Parking garage lighting controls & 17 & 14 & 12 & 43 \\
\hline 38 & Boiler temperature reset & 13 & 11 & 19 & 43 \\
\hline 39 & Refrigeration system condenser controls & 19 & 14 & 10 & 43 \\
\hline 40 & HW and CW temperature reset controls & 14 & 10 & 18 & 42 \\
\hline 41 & Refrigeration system compressor controls & 18 & 14 & 10 & 42 \\
\hline 42 & Heat rejection fan variable flow controls & 13 & 13 & 15 & 41 \\
\hline 43 & Walk-in cooler and freezer controls & 18 & 14 & 9 & 41 \\
\hline 44 & $\begin{array}{l}\text { Air curtain controls for velocity and maximum } \\
\text { velocity }\end{array}$ & 12 & 18 & 10 & 40 \\
\hline 45 & SWH pressure booster pump control & 13 & 13 & 14 & 40 \\
\hline 46 & Refrigerated display case controls & 17 & 14 & 9 & 40 \\
\hline 47 & WLHP loop flow controls & 15 & 15 & 9 & 39 \\
\hline 48 & WLHP loop temperature deadband controls & 15 & 12 & 9 & 36 \\
\hline 49 & WLHP loop heat rejection controls & 13 & 13 & 9 & 35 \\
\hline 50 & Control of dynamic glazing & 13 & 14 & 8 & 35 \\
\hline 51 & Escalator and moving walkway demand control & 10 & 14 & 10 & 34 \\
\hline
\end{tabular}




\subsection{Survey of Commissioning Agents}

One of the most important roles of commissioning agents is to ensure that building controls are installed and operating per the project design intent. Thus, they are in a very good position to assess the inclusion and performance of code-required controls in new buildings. PNNL contracted with Group 14 Engineering to conduct ten telephone interviews with commissioning agents to determine the relationship of the commissioning process to code compliance, and the extent of compliance with the 14 selected measures. To glean this information, a series of questions described in Section 3.2 were posed to each of the commissioning agents.

\subsection{Recruitment of Commissioning Agents}

The following guidelines were provided to Group 14 Engineering for recruitment of the ten commissioning agents to participate in the survey:

- No more than one commissioning agent employed by the contracting firm shall be interviewed and that person shall not have direct involvement in this interview process.

- Commissioning agents from a variety of geographic areas within the United States are preferred.

- Commissioning agents working almost exclusively on high performance or green buildings should be avoided.

- Commissioning agents should have commissioned a minimum of 30 non-residential buildings.

Ten interviews were conducted between March $14^{\text {th }}$ and $24^{\text {th }}$, 2016, with commissioning agents located in Colorado, Washington, California, Florida, Arizona, Texas, Kentucky, and Ontario, Canada. Commissioning agents indicated experience commissioning between 30 and 1,000 buildings each, with an average of 215 buildings commissioned.

\subsection{Results of Survey of Commissioning Agents}

The following sections summarize the results of the surveys. Complete responses can be found in Appendix B.

\subsubsection{General Questions}

1. As a commissioning agent, is energy code compliance verification included in your scope or do you limit compliance verification to complying with the contract documents; leaving code compliance to the design professional and Authority Having Jurisdiction?

Six of the ten interviewees answered that energy code compliance was not part of their scope. Of the four that answered yes, two were from Washington and one each from California and Austin, Texas; all of which have codes that include more detailed commissioning and document submission requirements than either of the model codes. 
2. Does the scope of work for your commissioning services typically include the following:

- Design review of lighting and HVAC system for compliance with energy codes,

- Design review of lighting and HVAC controls plans and specifications for compliance with energy codes,

- Lighting and HVAC controls submittal review, including sequence of operation, for compliance with energy codes,

- Functional testing of building controls, including verification of proper implementation of energy code-required controls,

- Controls data trend analysis after occupancy to verify proper functioning of energy coderequired controls.

Five of the ten interviewees indicated that they reviewed the design of the lighting and HVAC systems, the lighting and HVAC controls plans and specifications, and the contractor's submittals including sequence of operations for compliance with energy codes. Three of ten (from Washington and California) perform functional testing and trend analysis to verify proper code compliance.

3. In your opinion, do construction documents typically provide sufficient information for successful implementation of controls for HVAC and lighting systems?

None of the interviewees answered yes to this question. Six responded negatively and four indicated mixed findings depending on the designer or the measure in question. Four noted a lack of proper control sequences or setpoints as omissions. They pointed out that factory-provided control sequences are typically not submitted to the commissioning agent for review.

4. In your opinion, do control contractors generally meet all control sequence requirements specified in the construction documents?

Two respondents indicated yes and two indicated no. The others offered mixed responses. Three of the remaining six indicated that the contractor will "eventually get it right" when held to the task by the commissioning agent. The final three found that it depends on the contractor and the measure.

5. Approximately what percent of the time do you find control contractors include these measures in their installation if not required by the construction documents?

Responses ranged from $0 \%$ (three respondents) to 90\% (two respondents). Two respondents indicated $10 \%$ and one each for $50 \%, 60 \%$, and $65 \%$.

6. In your opinion, what are the greatest impediments to, or necessary additions for, successful implementation of code-required controls?

The following summarizes the responses received:

- Six of ten responses identified a need for better training of design engineers.

- Three respondents indicated the code was too complicated or changed too often.

- Two respondents mentioned lack of well-defined control sequences. 
- Owners desire a simple building.

- Lack of clear design intent.

- Improper training of Authorities Having Jurisdiction.

- Lack of clear delineation of responsibilities between mechanical engineer and commissioning agent.

- $\quad$ Lack of team coordination meetings.

- Lack of testing, training and certification for installers.

Figure 1 summarizes the responses to questions 1 through 4, and Figure 2 summarizes the response to question 5.

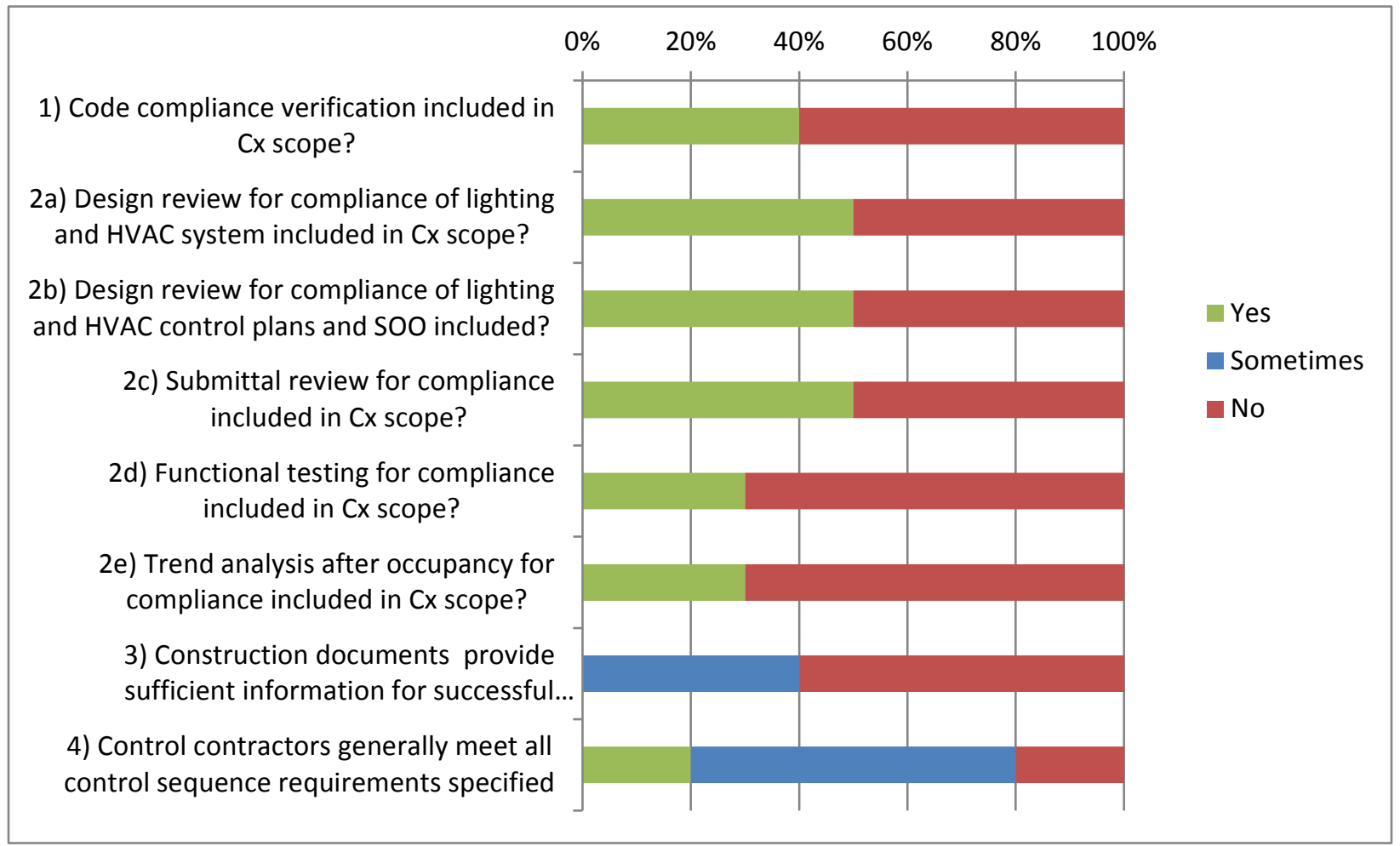

Figure 1. Commissioning Agent Responses to Questions 1 through 4 


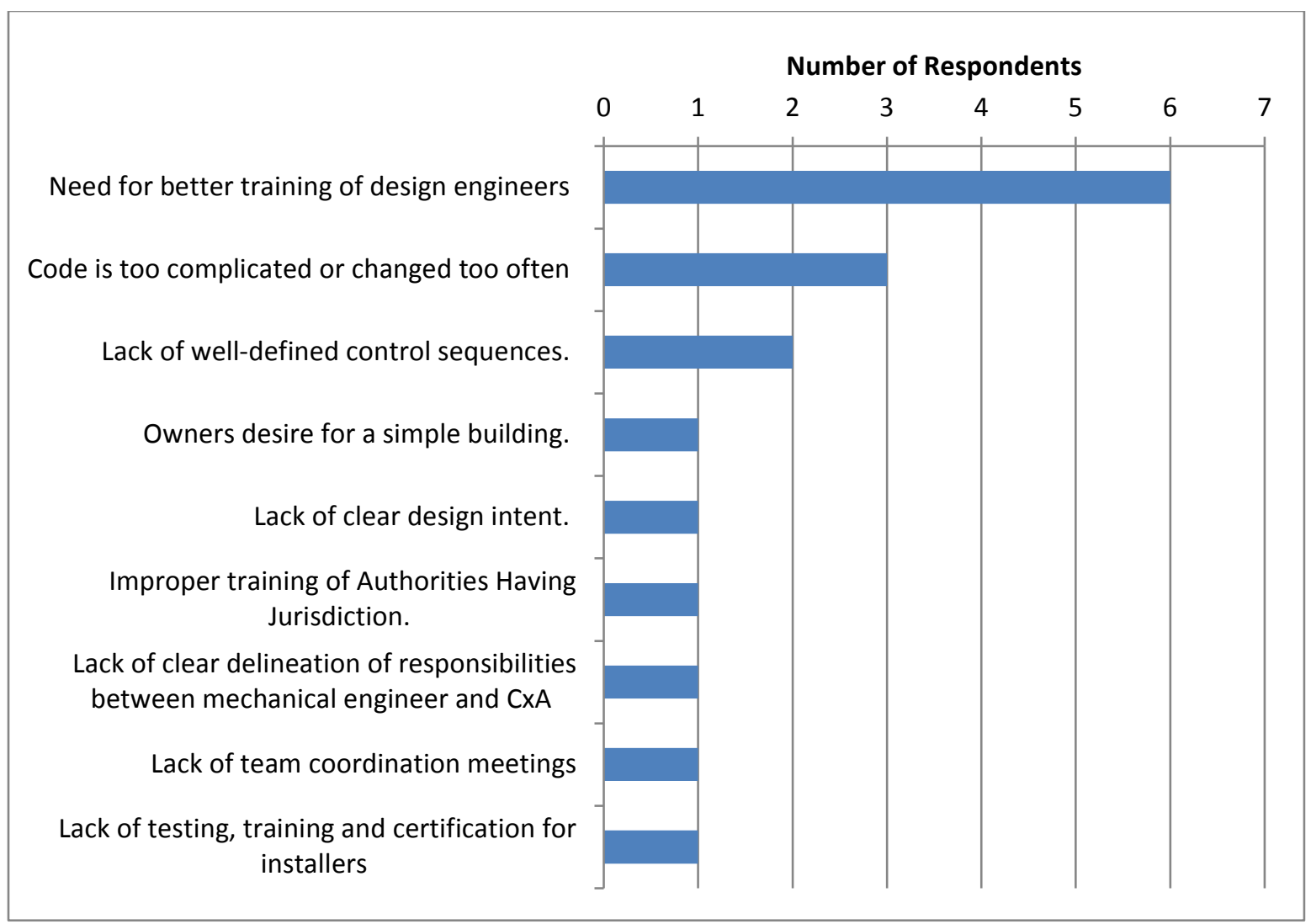

Figure 2. Question 5 - Greatest Impediments to Successful Implementation of Code-Required Controls

\subsubsection{Measure Specific Results}

\subsubsection{Summary of Measure Specific Results}

The following set of questions was asked for each of the 14 impactful code measures previously identified. Responses for all measures are summarized below each question. Figure 3 shows the combined responses to questions one through six graphically.

1. Are you familiar with the requirement?

Eight out of ten commissioning agents were familiar with all 14 controls measures. One was familiar with 12 of 14 and one with only 8 of 14 .

2. Do you perform design review and testing for code compliance?

Interviewees indicated that they commissioned the measures for code compliance an average of 36\% of the time. Responses ranged from 30\% to 50\%, depending on the code requirement. Responses were consistent with the initial general questions. 
3. How well do construction documents specify sequence?

Interviewees indicated an average of $41 \%$ of code-required control strategies have the adequate controls specification required for implementation. Adequate specifications by control strategy varied from an average of $10 \%$ for daylighting controls to $80 \%$ for off-hour setback controls.

4. What percent of the time do you find the measure meeting the code requirements on the first pass of functional testing?

Interviewees indicated an average of 51\% of code-required control strategies were operating as required at the first round of functional testing. Limits on simultaneous heating and cooling was the most problematic at $10 \%$ and zone isolation the least at $76 \%$. The commissioning agents noted that they do not review VAV box schedules to verify a minimum airflow setting at $30 \%$ or lower of the maximum airflow setpoint for each VAV box.

5. What percent of the time do you find the measure meeting code or requirements at the completion of commissioning?

Interviewees indicated an average of $79 \%$ of code-required control strategies were operating as required by code at the conclusion of commissioning. Limits on simultaneous heating and cooling remained the most problematic at $10 \%$ and off-hour setback the least problematic with $98 \%$ compliance. The $5^{\circ} \mathrm{F}$ thermostat deadband requirement compliance rate was low at $56 \%$; owners often feel a $5^{\circ} \mathrm{F}$ thermostat deadband is too wide.

6. If the measure is not operating as required by code, what percentage of buildings have necessary hardware \& software to meet code?

Interviewees indicated an average of $88 \%$ of code-required control strategies had the necessary equipment and software to meet codes. Interviewees struggled to answer this question consistently; three were unable to provide meaningful responses, so the $88 \%$ may be an overestimate.

7. What are the common deficiencies associated with each measure?

Responses are included in the measure specific discussion in the next section.

8. What can be done to help ensure each measure is correctly implemented?

Responses are included in the measure-specific discussion in the next section. 


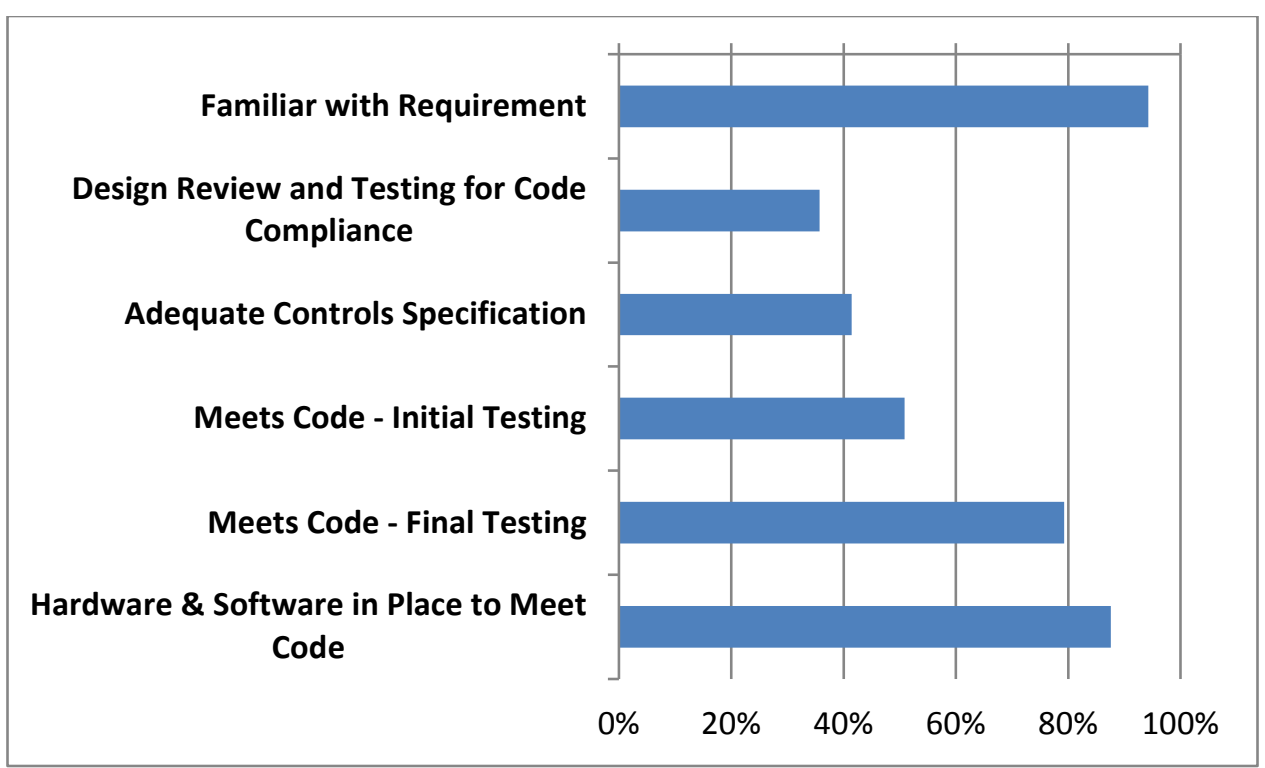

Figure 3. Commissioning Agent Responses - Combined for all Measures

\subsubsection{Individual Measure Results and Comments}

This section provides measure-specific highlights and a summary of responses to the questions raised in the previous sections. A graphical representation of the answers is found in Figure 4. More detailed responses can be found in Appendix B.

1. Five-degree thermostat deadband and setpoint overlap prevention

Construction documents often do not specify $5^{\circ} \mathrm{F}$ deadband. Owners generally feel the deadband is too wide; commissioning agents will not override the owner's wish. The code wording, "shall be capable of a deadband of at least $5^{\circ} \mathrm{F}$," does not mean it must be set at $5^{\circ} \mathrm{F}$. In Florida, it's always set at $6^{\circ} \mathrm{F}$ due to reheating concerns.

Familiar with Requirement $90 \%$

Design Review and Testing for Code Compliance $\quad 30 \%$

Adequate Controls Specification 30\%

Meets Code - Initial Testing $\quad 46 \%$

Meets Code - Final Testing $\quad 56 \%$

Hardware \& Software in Place to Meet Code $\quad 93 \%$

\section{Occupant-based interior lighting controls}

Construction documents do not adequately specify lighting controls including setpoints, occupancy sensor types, and circuits controlled. Lighting contractors often do not respond to lighting control issues.

Familiar with Requirement

Design Review and Testing for Code Compliance

Adequate Controls Specification

Meets Code - Initial Testing

Meets Code - Final Testing

Hardware \& Software in Place to Meet Code
$90 \%$

$40 \%$

$20 \%$

$49 \%$

$84 \%$

$86 \%$ 


\section{Economizer integration and high limit controls}

Very well understood strategy. Most common deficiencies are poor programming, inoperable dampers or dampers that do not move to correct position, and calibration of humidity sensors. Economizers often controlled by rooftop unit controller, requiring factory technician to program.

$\begin{array}{ll}\text { Familiar with Requirement } & 100 \% \\ \text { Design Review and Testing for Code Compliance } & 40 \% \\ \text { Adequate Controls Specification } & 50 \% \\ \text { Meets Code - Initial Testing } & 46 \% \\ \text { Meets Code - Final Testing } & 73 \% \\ \text { Hardware \& Software in Place to Meet Code } & 95 \%\end{array}$

4. Off-hour automatic temperature setback and system shutoff

Very well understood strategy. Most common deficiencies are poor programming, night override buttons not enabled, outside air dampers open during morning warm-up, and failure of mechanical design engineer to specify time schedule. If schedule is not provided, it doesn't get programmed.

$\begin{array}{ll}\text { Familiar with Requirement } & 100 \% \\ \text { Design Review and Testing for Code Compliance } & 40 \% \\ \text { Adequate Controls Specification } & 80 \% \\ \text { Meets Code - Initial Testing } & 62 \% \\ \text { Meets Code - Final Testing } & 91 \% \\ \text { Hardware \& Software in Place to Meet Code } & 98 \%\end{array}$

5. Limits on simultaneous heating and cooling - airside

Poorly understood strategy. Everyone understands not heating and cooling simultaneously, but strategy is really about operating VAV boxes at no more than $30 \%$ of design flow during reheating, which is listed as an expectation. When interviewer pressed on 30\% limit, no one indicated they checked the design VAV box schedule for the limit or addresses it in functional testing.

$\begin{array}{ll}\text { Familiar with Requirement } & 100 \% \\ \text { Design Review and Testing for Code Compliance } & 0 \% \\ \text { Adequate Controls Specification } & 60 \% \\ \text { Meets Code - Initial Testing } & 10 \% \\ \text { Meets Code - Final Testing } & 10 \% \\ \text { Hardware \& Software in Place to Meet Code } & 96 \%\end{array}$

6. Automatic outdoor air damper controls

Well-understood strategy. Most common deficiencies are poor programming, inoperable dampers or failed actuator.

Familiar with Requirement $\quad 90 \%$

Design Review and Testing for Code Compliance $\quad 30 \%$

Adequate Controls Specification $\quad 50 \%$

Meets Code - Initial Testing $\quad 68 \%$

Meets Code - Final Testing $\quad 87 \%$

Hardware \& Software in Place to Meet Code $\quad 81 \%$ 


\section{Supply air temperature reset - reheat systems}

Well-known strategy, but code is vague on control strategy. Detailed sequences are typically missing in the construction documents and it's a very complex strategy which significantly affects reheating, economizer operation, and fan energy. The strategy needs to be addressed and specified in detail.

$\begin{array}{ll}\text { Familiar with Requirement } & 90 \% \\ \text { Design Review and Testing for Code Compliance } & 40 \% \\ \text { Adequate Controls Specification } & 20 \% \\ \text { Meets Code - Initial Testing } & 50 \% \\ \text { Meets Code - Final Testing } & 92 \% \\ \text { Hardware \& Software in Place to Meet Code } & 91 \%\end{array}$

\section{Daylighting controls implemented correctly when required}

Well-understood strategy, but construction documents do not adequately specify lighting controls $90 \%$ of the time according to the interviewees. Daylighting designer is likely the only person who knows the illumination levels designed for each space. Some doubt as to whether the daylighting system was simulated for optimal glass properties, luminaire selection and location, and sensor placement. Common deficiencies include sensor location, inappropriate sensors, integration with proprietary control components, and lack of setpoints. Lighting contractors often do not respond to lighting control issues. Daylighting code requirements have become very complex.

$\begin{array}{ll}\text { Familiar with Requirement } & 100 \% \\ \text { Design Review and Testing for Code Compliance } & 40 \% \\ \text { Adequate Controls Specification } & 10 \% \\ \text { Meets Code - Initial Testing } & 45 \% \\ \text { Meets Code - Final Testing } & 83 \% \\ \text { Hardware \& Software in Place to Meet Code } & 80 \%\end{array}$

\section{Zone isolation controls}

Well-understood strategy. Several commissioning agents commented on the large maximum zone size of 25,000 $\mathrm{ft}^{2}$. Common deficiencies include dampers not installed and lack of programming. Design reviews were cited as a way to verify compliance with the requirement.

Familiar with Requirement $\quad 90 \%$

Design Review and Testing for Code Compliance $\quad 30 \%$

Adequate Controls Specification $\quad 70 \%$

Meets Code - Initial Testing $\quad 76 \%$

Meets Code - Final Testing $\quad 96 \%$

Hardware \& Software in Place to Meet Code $\quad 73 \%$

\section{Demand controlled ventilation (DCV)}

A common strategy, but not well understood by designers. Commissioning agents from Washington and California noted good success with DCV, which they attribute to focused education of mechanical engineers and contractors in their states. Everyone else struggles with inadequate design and poor performance at initial functional testing. Common deficiencies include inadequate design specifications, 
poor programming, $\mathrm{CO}_{2}$ sensor calibration, sensor location, inoperable dampers, and poor airflow measurement at the rooftop unit. Systems may hit 91\% compliance at completion of Cx.

Familiar with Requirement $\quad 100 \%$

Design Review and Testing for Code Compliance $\quad 30 \%$

Adequate Controls Specification $\quad 40 \%$

Meets Code - Initial Testing $\quad 56 \%$

Meets Code - Final Testing $\quad 91 \%$

Hardware \& Software in Place to Meet Code $\quad 79 \%$

\section{Exterior lighting controls}

Well-understood strategy. Most common deficiencies are lack of or poor controls specification, programming, wiring problems, photo sensor location, and overlooking it all together.

Familiar with Requirement $\quad 90 \%$

Design Review and Testing for Code Compliance $\quad 50 \%$

Adequate Controls Specification $\quad 40 \%$

Meets Code - Initial Testing $\quad 55 \%$

Meets Code - Final Testing $\quad 87 \%$

Hardware \& Software in Place to Meet Code $\quad 86 \%$

\section{Fan static pressure reset controls}

Well-understood strategy. Most common deficiencies are poor or missing design sequences, programming, and sensor location. Successful implementation requires coordination between test and balance contractor and controls technician to balance system for operation at lowest possible duct static pressure. Control sequence is complex, requiring polling of all VAV boxes. Owner and maintenance personnel are sometimes resistant to this strategy due to its complexity.

Familiar with Requirement $\quad 100 \%$

Design Review and Testing for Code Compliance $\quad 30 \%$

Adequate Controls Specification 30\%

Meets Code - Initial Testing $\quad 55 \%$

Meets Code - Final Testing $\quad 92 \%$

Hardware \& Software in Place to Meet Code $\quad 94 \%$

\section{Timer-based interior lighting controls}

Well-understood strategy. Most common problems are poor zoning, coordination on scheduling, lack of consistent circuit naming from design through commissioning, and wiring.

Familiar with Requirement $\quad 80 \%$

Design Review and Testing for Code Compliance $\quad 30 \%$

Adequate Controls Specification $\quad 40 \%$

Meets Code - Initial Testing $\quad 58 \%$

Meets Code - Final Testing $\quad 90 \%$

Hardware \& Software in Place to Meet Code $\quad 84 \%$ 


\section{Optimum start controls}

Well-understood strategy. Most common deficiencies are poor programming, sensor location, links to weather stations, and lack of follow-up with trending to verify proper functioning. Optimum start control is typically provided by the controls contractor using their own algorithm. The building automation system must learn and adjust parameters after occupancy to dial in optimum operation. Trending after occupancy is required to verify performance.

Familiar with Requirement

Design Review and Testing for Code Compliance

Adequate Controls Specification

Meets Code - Initial Testing

Meets Code - Final Testing

Hardware \& Software in Place to Meet Code
$100 \%$

$40 \%$

$40 \%$

$36 \%$

$78 \%$

$90 \%$ 


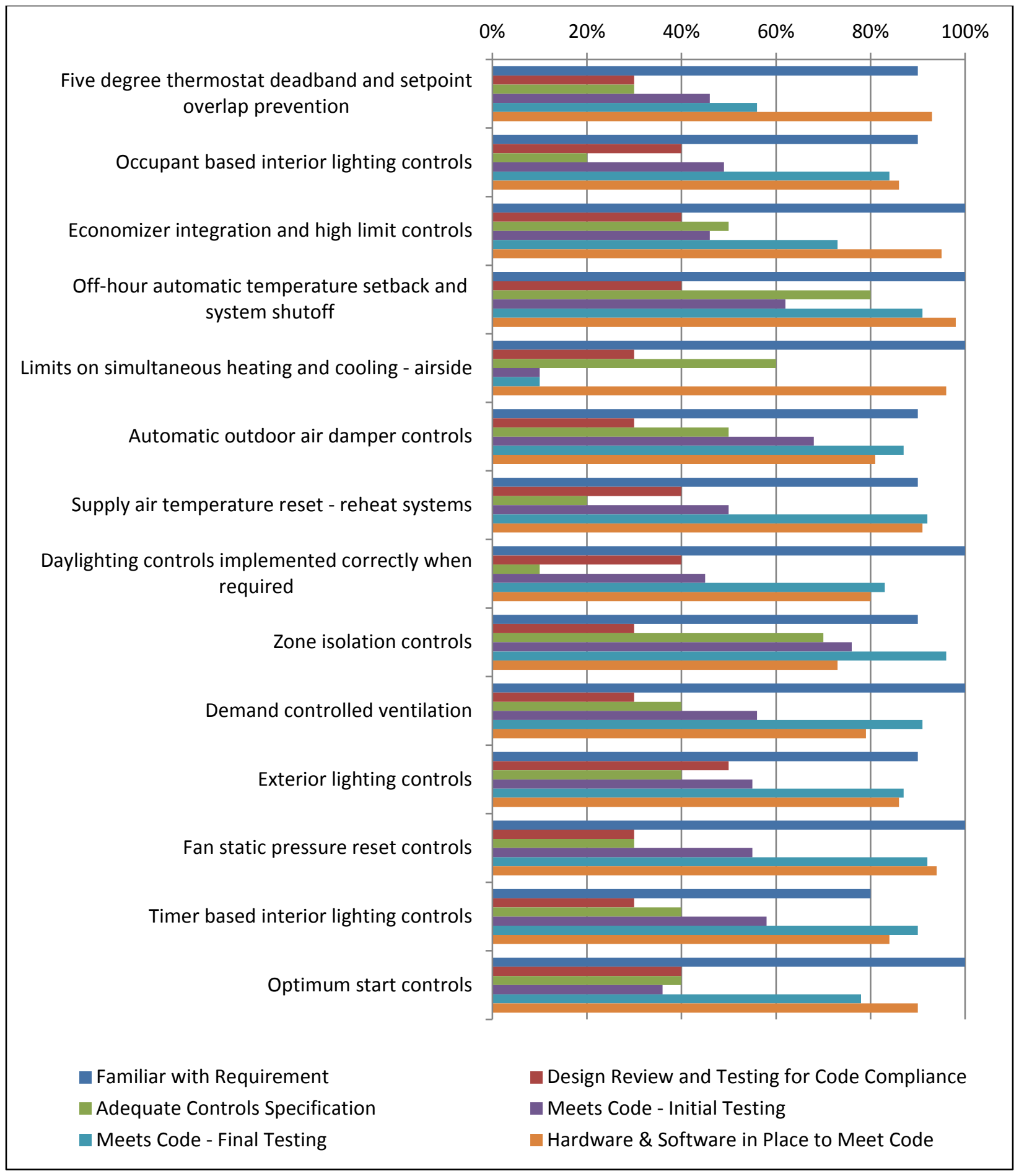

Figure 4. Commissioning Agent Responses to Measure Specific Questions 


\subsubsection{Summary of Interview Results}

The survey of commissioning agents was conducted to help answer the question: To what degree are high-impact controls requirements correctly implemented in new buildings? The overall answers to this question are:

Commissioning agents estimate that $79 \%$ of the 14 high-impact control strategies are operating in compliance with code requirements at the completion of commissioning. The average range of compliance by strategy is from $10 \%$ to $96 \%$. These quantitative questions were asked with specific reference to code compliance and represent the commissioning agent's opinion of the degree of compliance with the codes. However, the reported code strategy compliance rate may be inflated, considering the following factors.

1. Only four of the 10 commissioning agents interviewed regard code compliance verification to be in their scope of services. Three of these four practice in Washington or California which have their own state energy codes and where the commissioning agent is required to be involved in code compliance (CEC 2015; Washington State 2014). When asked about verifying code compliance via design review, control sequence review, submittal review, functional testing, or trend analysis, no more than 50\% responded yes. For all 14 measures, the percentage of commissioning agents that indicated they tested the measure for compliance was lower than the percentage that met code during final testing. Given the low percentage checking compliance by any means, the reported 79\% compliance estimate is likely unrealistic.

2. Eight of ten commissioning agents were familiar with all 14 control strategies, one commissioning agent was familiar with 12 of 14, and one commissioning agent was only familiar with 8 of 14. All 10 commissioning agents review construction documents and contractor control submittals for functional and commissionable control. Most commissioning agents indicated that code compliance is the responsibility of the design engineer and that the commissioning agent's responsibility is to verify contractor compliance with the construction documents.

3. The interviews identified deviations from code compliance in the following areas:

- All ten commissioning agents allow deviation in the $5^{\circ} \mathrm{F}$ thermostat deadband requirement, depending on the owner's preference, typically down to $4^{\circ} \mathrm{F}$. The commissioning agent is the owner's representative and generally complies with the owner's instructions.

- None of the commissioning agents indicated they reviewed the VAV box schedule in the construction documents for compliance with the maximum 30\% VAV box airflow setpoint in reheating, a requirement of the limits on simultaneous heating and cooling strategy.

- The commissioning agents indicated that the code requirements and resulting control sequences for supply air temperature reset and demand ventilation control are often vague and can take different approaches for code compliance. Commissioning agents indicate verification of compliance with specified control sequences; however, not all those sequences will produce the expected energy savings.

- Lighting control strategies generally score lower in code compliance; daylighting system and controls design is often noted as being poor.

- Optimum Start Control scores low in code compliance. 
4. Commissioning agents indicated an average of only $41 \%$ of the 14 high-impact control strategies had adequate controls specifications.

Based on the above information, actual code compliance is likely a good deal less than the $79 \%$ figure reported. 


\subsection{Field Assessment of Implementation of Controls Requirements}

To assess actual design and operation of the 14 impactful lighting and HVAC system controls requirements from the most recent model code requirements, PNNL contracted with Solarc Energy Group to perform onsite audits and design document evaluations of newly constructed non-residential buildings in several states and climate zones. The intent was to evaluate these buildings within one year of occupancy so that observed field conditions approximate their state at the time a certificate of occupancy was granted. Up to two years after occupancy was allowed given that recruitment was identified as a major hurdle in a previous study (Rosenberg et al. 2016). The contractor was asked to determine the following for each building:

\section{General Building Questions}

1. Code the building was constructed under

2. Date the certificate of occupancy was granted

3. Occupancy type of the building

4. Conditioned floor area associated with each occupancy type

5. Whether the building was commissioned

6. Whether the building qualified for any beyond code energy incentive program such as LEED certification or utility or tax incentives

\section{Questions for Each of the 14 Controls Requirements}

1. From review of the controls documents including specifications and sequence of operations, was the system specified to correctly to meet the code? If not, what was missing?

2. Was this control requirement commissioned? Is there a commissioning report documenting this?

3. Does the building include all the required equipment, sensors, hardware, and software to implement the control requirement? In other words, is the building capable of achieving the operations described in the code? If not, what is missing?

4. Are the controls configured to actually achieve the operations described in the code? If not, how does it vary?

\subsection{Assessment Protocol}

Design reviews and field visits were conducted on twenty-four (24) newly constructed buildings in seven states across the Western United States from June through September 2016. Compliance for each applicable measure was scored from three perspectives - design, configuration and capability. A scoring approach for each measure was developed, as described below. The same scoring approach was applied to each perspective, to result in a score between zero and ten for each perspective. Zero indicates complete 
non-compliance and ten indicates full compliance. The scores for each perspective were determined using different source information, as follows:

- Design perspective scoring was based on a review of the design documents for each building to verify complete inclusion of code related requirements.

- Configuration perspective scoring was based on the actual equipment and operating conditions documented during a site visit to each building.

- Capability perspective scoring was based on a review by the field auditors of the potential of the control systems to be easily adjusted through setpoint or schedule modification to maximize code compliance. In other words, could the existing equipment and programming at the site be adjusted to comply with the setpoints or operation required in code language without the need for reprogramming or additional equipment or devices?

- Several measures were broken into separate requirements and a portion of the ten points were awarded for compliance with each. For example the occupancy sensor measure has a requirement that the sensor needs to de-energize lights when no one is present. There are also requirements that the delay before lights go out can be no longer than 30 minutes and the lights cannot all be turned on automatically when an occupant enters. The point allocation for this and other measures is described in the next section.

\section{Measure 1: Set Point Overlap Restriction}

Scoring was based on the actual deadband in the direct digital control (DDC) system or thermostat. If there was no deadband, zero points were assigned. A deadband of $5^{\circ} \mathrm{F}$ or more earned all ten points. Points were assigned linearly between the maximum and minimum for systems with a specified deadband between $0^{\circ}$ and $5^{\circ} \mathrm{F}$ ( 1 point per each half of a degree). All modern thermostats and DDC systems are capable of providing the required deadband so capability was given a ten for all buildings.

\section{Measure 2: Economizer Integration and High Limit}

Scoring was broken up into five points for economizer presence and five points for miscellaneous controls associated with economizer function.

Economizer presence. For systems with no economizer capability when economizers were required, zero points were assigned. Five points were assigned for systems with $100 \%$ of cooling being able to be met by the economizer, and points were assigned linearly in between the maximum and minimum based on the percentage of cooling met (one point for each 20\%).

Miscellaneous controls. One point was added if the economizer control signal (i.e., drybulb or enthalpy) was code compliant. Another two points were assigned for the economizer high limit set point. For dry-bulb temperature control, a setpoint of $75^{\circ} \mathrm{F}$ earned both points while a setpoint of $70^{\circ} \mathrm{F}$ or no specification of high limit setpoint earned zero points. Scores for systems with setpoints in between $70^{\circ} \mathrm{F}$ and $75^{\circ} \mathrm{F}$ were assigned linearly (one point per $0.4^{\circ} \mathrm{F}$ ). Integrated economizer cooling and relief air damper each earned an additional point, subject to applicable requirements for simple and complex 
HVAC systems. For most buildings, scoring was based on meeting the climate zone specific control signal requirement (outside air dry-bulb temperature for all climate zones addressed in this research effort). In some cases, economizers used control technology that exceeded the basic code requirements, i.e., electronic enthalpy control or dual temperature control. In these cases, points were awarded on equivalence to the minimum dry-bulb temperature controls.

\section{Measure 3: Off-Hour Automatic Setback Control}

Scoring was broken up with a maximum of eight points being assigned for specified off-hour deadband greater than or equal to $30^{\circ} \mathrm{F}$. Points were assigned linearly from zero to eight for systems with a deadband between $0^{\circ} \mathrm{F}$ and $30^{\circ} \mathrm{F}$ (one point for each $3.75^{\circ} \mathrm{F}$ ). Two additional points were assigned for thermostats or other controls with seven-day programming and manual override ability.

\section{Measure 4: Limits on Simultaneous Heating and Cooling}

Scoring was broken up into five points for both heating and cooling minimum flow ratios for VAV terminal units. Boxes with a minimum flow rate of $30 \%$ or less were given the full five points and constant volume boxes were assigned zero points. Boxes with minimums between $30 \%$ and $100 \%$ were assigned points linearly (one point for each 14\%).

\section{Measure 5: Automatic Outdoor Air Dampers}

Up to five points were assigned for each of the following requirements: unoccupied period lockout of outside air and outside air lockout during morning warm-up. Zero points were given if there was no automatic damper or no lockout.

\section{Measure 6: Supply Air Temperature Reset}

Scoring was based on the difference between the reset sequence high and low limits. Systems with a delta of $5^{\circ} \mathrm{F}$ were assigned ten points. If there is no sequence specified or the delta is $0^{\circ} \mathrm{F}$., then zero points were given. Points were assigned linearly for limit deltas between zero and five ( 2 points for each degree).

\section{Measure 7: Zone Isolation Controls}

Scoring was based on the percentage of the total applicable square footage that has effective zone isolation controls. Effective zone isolation control accounted for the percentage of total unoccupied air flow that was eliminated. For example, if installed zone isolation dampers eliminated $50 \%$ of the required air flow in areas where they were installed, applicable points would be reduced by $50 \%$. A maximum of 10 points was available. For a case without any required shutoff control, zero points were assigned. For a measure with zone isolation control in $100 \%$ of the floor area required but only reduced unoccupied period flow to $50 \%$ of the occupied period flow, the compliance score was 5 points (10 points maximum x 50\%). 


\section{Measure 8: Demand Controlled Ventilation}

Scoring was based on the percentage of the total applicable square footage that has DCV. If there was no DCV in areas where it was required, zero points were assigned. If there was DCV in all areas where required, then ten points were assigned.

\section{Measure 9: Fan Static Pressure Reset}

Scoring was based on the difference between the reset sequence high and low limits. Ten points were assigned if the difference between the limits was greater than or equal to 0.5 inch w.c., and zero points were assigned if the difference was 0.0 inch w.c. or not specified at all ( 2 points per 0.1 inch w.c.). One point was deducted if the duct static pressure sensor location was not specified or was located at the fan discharge. An additional point was deducted if the reset sequence control signal was not based on the terminal unit calling for the most air.

\section{Measure 10: Optimum Start Controls}

Scoring was based on the percent of system airflow with optimum start controls when required. 100\% coverage received 10 points and $0 \%$ coverage received no points with one point awarded for each $10 \%$ between $0 \%$ and $100 \%$.

\section{Measure 11: Occupant-Based Interior Light Controls}

Scoring was broken up into eight points for the required installation of controls and one point each for both vacancy sensing control and time delay control for occupancy sensors.

\section{Measure 12: Daylight Controls}

Scoring was based on the percentage of area in daylight zones that had compliant daylighting controls (either manual or automatic as required). A maximum of eight points were assigned if $100 \%$ of the required area had daylight controls. An additional two points were assigned if there were daylight dimming controls (stepped or continuous dimming) and if the minimum output fraction for the controls met the requirement (35\% in the 2012 IECC).

\section{Measure 13: Exterior Lighting Controls}

Scoring was based on the percentage of connected load equipped with code-compliant controls. Ten points were assigned if the entire load was equipped with controls. Zero points were assigned if none of the load was controlled. Points were assigned linearly for percentages between zero and 100 (one point for each $10 \%)$.

\section{Measure 14: Timer-Based Interior Lighting Controls}

Scoring was based on the percentage of connected load with timer-based controls with a maximum of seven points for $100 \%$ of the load being controlled. An additional point was added for each of the 
following controls requirements that were met: occupant override switches provided, seven-day programming capability, and holiday programming capability.

\subsection{Recruitment}

For the most part, building recruitment was left to the contractor with the following guidelines provided:

1. Buildings must be newly constructed with occupancy occurring within the past 24 months, preferably within the past 12 months.

2. Buildings must cover at least three different climate zones.

3. Building location must be sufficiently distributed to result in their being located in significantly different energy code compliance cultures.

4. Target of 15 observations for each measure. Go to at least 25 buildings to try to obtain this number.

5. Recruiting protocol should avoid a non-representative sample of high performance or green buildings.

6. No more than five candidate buildings shall be less than $10,000 \mathrm{ft}^{2}$.

\subsubsection{Calling Approaches}

Building recruitment used a combination of warm call and cold call techniques. The cold call approach involved internet searches of public databases for jurisdictions in and around Phoenix, AZ; Tucson, AZ; Las Vegas, NV; and Denver, CO. The search focused on Building Permit Applications and Certificates of Occupancy in public databases for issuing agencies (primarily municipalities) that are available via the internet. Well over 100 potential projects were extracted and reviewed as potential candidate buildings. Additional research was required to determine the current status of the building and to identify potential contacts, usually the project architect, the general contractor, or the building's marketing director.

Out of the 100 permits that were researched, only 20 met all of the criteria and only a single building was successfully recruited. This $5 \%$ cold call recruiting success rate is similar to a previous study which reported a 7\% success rate (Rosenberg et al. 2016).

The warm call approach involved email, telephone, and personal communications with selected industry contacts known to Solarc. Typical communication involved asking whether that individual or their firm had worked on any building that had been constructed in the past 12-24 months and permitted under the current set of energy codes. For projects that fit both criteria, efforts were made to contact a building owner representative to determine potential interest in participating in the project. Contact was made to every building owner regardless of the size, occupancy type, or energy efficiency features.

Outreach was made to approximately 50 contacts (typically architects, engineers, facility managers, or utility staff) who identified candidate buildings. A total of 23 buildings were recruited for a success rate of just over $20 \%$. Despite familiar contacts for the warm call approach, building representatives were 
often challenged to see the immediate benefit to their organization and most initially declined to participate. As an encouragement, Solarc committed to providing building-specific recommendations including a tune-up checklist for each building.

\subsubsection{Recruiting Results}

Twenty-four buildings in the Pacific Northwest and Mountain regions, ranging in size from 10,300 to $242,500 \mathrm{ft}^{2}$ with a median size of $70,000 \mathrm{ft}^{2}$ were evaluated. They included office, medical, retail, and educational occupancies. Of the total number of subject buildings recruited, warm call techniques were responsible for $96 \%$ (23 out of 24) of the scheduled participating buildings. As has been the case in previous compliance efforts, recruiting proved to be extremely challenging. Table 3 shows the distribution of successfully recruited buildings by state and climate zone, and Table 4 lists the buildings, their locations, climate zones, occupancy types, sizes, and HVAC system types. To maintain anonymity, the buildings are given pseudonyms for this report.

Table 3. Distribution of Buildings Successfully Recruited

\begin{tabular}{lcc}
\hline Location (State) & Climate Zone & No. of Buildings \\
\hline Colorado & 5B & 1 \\
Idaho & 5B & 3 \\
Oregon & 4C & 4 \\
Utah & 5B & 6 \\
Washington & 4C & 2 \\
Washington & 5B & 4 \\
Wyoming & 6B & 4 \\
\hline Total & & $\mathbf{2 4}$ \\
\hline
\end{tabular}

Table 4. Summary of Successfully Recruited Buildings

\begin{tabular}{llcccl}
\hline $\begin{array}{c}\text { Building } \\
\text { Pseudonym }\end{array}$ & \multicolumn{1}{c}{ Location } & $\begin{array}{c}\text { Climat } \\
\text { e Zone }\end{array}$ & $\begin{array}{c}\text { Occupancy } \\
\text { Type }\end{array}$ & $\begin{array}{c}\text { Area } \\
\mathbf{f t}^{2}\end{array}$ & \multicolumn{1}{c}{ HVAC Systems } \\
\hline Office Building A & Kennewick, WA & 5B & Office & 14,195 & $\begin{array}{l}\text { Dedicated Outdoor Air System } \\
\text { (DOAS), Split System direct } \\
\text { expansion (DX) }\end{array}$ \\
\hline Office Building B & Richland, WA & 5B & Office & 24,000 & $\begin{array}{l}\text { VAV Air Handling Unit (AHU), } \\
\text { Split System DX }\end{array}$ \\
\hline Office Building C & Beaverton, OR & 4C & Office & 19,000 & $\begin{array}{l}\text { Variable Refrigerant Flow (VRF), } \\
\text { DOAS }\end{array}$ \\
\hline Fitness Building A & Portland, OR & 4C & Fitness & 10,300 & VRF, DOAS, Hydronic Radiant \\
\hline Dormitory A & Seattle, WA & 4C & Dormitory & 113,195 & $\begin{array}{l}\text { DOAS, VAV AHU, Electric } \\
\text { Resistance }\end{array}$ \\
\hline Dormitory B & Seattle, WA & 4C & Dormitory & 219,910 & DOAS, VAV, Electric Resistance \\
\hline Retail A & Boise, ID & 5B & Retail & 16,250 & $\begin{array}{l}\text { Packaged Gas Furnace, Ductless } \\
\text { Split System }\end{array}$ \\
\hline
\end{tabular}




\begin{tabular}{|c|c|c|c|c|c|}
\hline $\begin{array}{c}\text { Building } \\
\text { Pseudonym }\end{array}$ & Location & $\begin{array}{l}\text { Climat } \\
\text { e Zone }\end{array}$ & $\begin{array}{l}\text { Occupancy } \\
\text { Type }\end{array}$ & $\begin{array}{c}\text { Area } \\
\mathbf{f t}^{2}\end{array}$ & HVAC Systems \\
\hline Retail B & $\begin{array}{l}\text { Salt Lake City, } \\
\text { UT }\end{array}$ & $5 \mathrm{~B}$ & Supermarket & 124,000 & $\begin{array}{l}\text { Packaged Gas Furnace, Ductless } \\
\text { Split System }\end{array}$ \\
\hline Medical Office A & Kennewick, WA & $5 B$ & $\begin{array}{l}\text { Medical } \\
\text { Office } \\
\text { Building }\end{array}$ & 13,000 & $\begin{array}{l}\text { Packaged Heat Pump, Packaged Gas } \\
\text { Furnace }\end{array}$ \\
\hline Hospital A & Taylorsville, UT & $5 B$ & Hospital & 10,500 & VRF, DOAS \\
\hline Medical Office B & Spokane, WA & $5 B$ & $\begin{array}{l}\text { Medical } \\
\text { Office } \\
\text { Building }\end{array}$ & 15,000 & $\begin{array}{l}\text { Packaged Gas Furnace, Ductless } \\
\text { Split System }\end{array}$ \\
\hline K-12 Education A & Twin Falls, ID & 5B & $\begin{array}{c}\mathrm{K}-12 \\
\text { Education }\end{array}$ & 70,700 & $\begin{array}{l}\text { Water Source Heat Pump (WSHP), } \\
\text { Packaged Gas Furnace, Energy } \\
\text { Recovery Ventilator (ERV) }\end{array}$ \\
\hline Office D & $\begin{array}{l}\text { West Valley City, } \\
\text { UT }\end{array}$ & $5 B$ & Office & 83,000 & $\begin{array}{l}\text { VRF, DOAS, Gas Unit Heaters, } \\
\text { Radiant Panels, Evaporative Cooling }\end{array}$ \\
\hline Hospital B & $\begin{array}{l}\text { Salt Lake City, } \\
\text { UT }\end{array}$ & 5B & Hospital & 242,470 & VAV AHU, Chiller, Boiler \\
\hline K-12 Education B & Casper, WY & $6 \mathrm{~B}$ & $\begin{array}{c}\text { K-12 } \\
\text { Education }\end{array}$ & 83,400 & VAV AHU, Chiller, Boiler \\
\hline K-12 Education C & Casper, WY & $6 \mathrm{~B}$ & $\begin{array}{c}\mathrm{K}-12 \\
\text { Education }\end{array}$ & 100,000 & $\begin{array}{l}\text { Single-Zone AHU, VAV AHU, 3- } \\
\text { Deck Multizone, Chiller, Boiler }\end{array}$ \\
\hline Medical Office C & Denver, CO & 5B & $\begin{array}{l}\text { Medical } \\
\text { Office } \\
\text { Building }\end{array}$ & 46,000 & Packaged VAV AHU \\
\hline $\begin{array}{l}\text { Higher Education } \\
\text { A }\end{array}$ & Laramie, WY & 6B & $\begin{array}{l}\text { Higher } \\
\text { Education }\end{array}$ & 107,000 & VAV AHU \\
\hline Multipurpose A & Roseburg, OR & $4 \mathrm{C}$ & Multipurpose & 16,230 & VRF, DOAS \\
\hline $\begin{array}{l}\text { Higher Education } \\
\text { B }\end{array}$ & Ogden, UT & 5B & $\begin{array}{c}\text { Higher } \\
\text { Education }\end{array}$ & 189,500 & VRF, VAV DOAS, Boiler, Chiller \\
\hline K-12 Education D & Eugene, OR & $4 \mathrm{C}$ & $\begin{array}{c}\text { K-12 } \\
\text { Education }\end{array}$ & 97,000 & Fan Coils, Boiler, Chiller \\
\hline K-12 Education E & Dugway, UT & 5B & $\begin{array}{c}\text { K-12 } \\
\text { Education }\end{array}$ & 72,000 & $\begin{array}{l}\text { Ground Source Heat Pump, Makeup } \\
\text { Air Unit with Evaporative Cooling, } \\
\text { Split System DX }\end{array}$ \\
\hline K-12 Education F & Twin Falls, ID & 5B & $\begin{array}{c}\text { K-12 } \\
\text { Education }\end{array}$ & 67,800 & WSHP, Packaged Gas Furnace, ERV \\
\hline K-12 Education G & Casper, WY & 6B & $\begin{array}{c}\text { K-12 } \\
\text { Education }\end{array}$ & 42,000 & VAV AHU, Chiller, Boiler \\
\hline
\end{tabular}

\subsection{Field Assessment Results}

The following sections summarize the results of the field assessment. Results are shown for each measure and each building and summarized by control type - lighting or HVAC. In the sections that follow, the measures are given the abbreviations shown in Table 5. Table 6 provides the raw compliance scores for each measure in each building for design, capability, and configuration. The results by measure and building are discussed in the sections that follow. 
Table 5. Abbreviations for Control Measures

\begin{tabular}{ccl}
\hline No. & Abbreviation & \multicolumn{1}{c}{ Control Measure Description } \\
\hline 1 & TstatDdBnd & Five degree thermostat deadband and setpoint overlap prevention \\
\hline 2 & EconoInt & Economizer integration and/or high limit controls \\
\hline 3 & TstatSetbk & Off-hour automatic temperature setback and system shutoff with manual override \\
\hline 4 & SimultHtCl & Limits on simultaneous heating and cooling - airside \\
\hline 5 & AutoDamp & Automatic outdoor air damper controls \\
\hline 6 & SAT-Reset & Supply air temperature reset - reheat systems \\
\hline 7 & ZoneIso & Zone isolation controls \\
\hline 8 & DCV & Demand controlled ventilation \\
\hline 9 & SP-Reset & Fan static pressure reset controls \\
\hline 10 & OptStart & Optimum start controls \\
\hline 11 & OccSenLtg & Occupant-based interior lighting controls \\
\hline 12 & DayLtgCtl & Daylighting controls implemented correctly when required \\
\hline 13 & ExtLtgCtl & Exterior lighting controls \\
\hline 14 & IntLtgCtl & Occupant-based interior lighting controls \\
\hline
\end{tabular}


Table 6. Compliance Scores for all Measures and Buildings

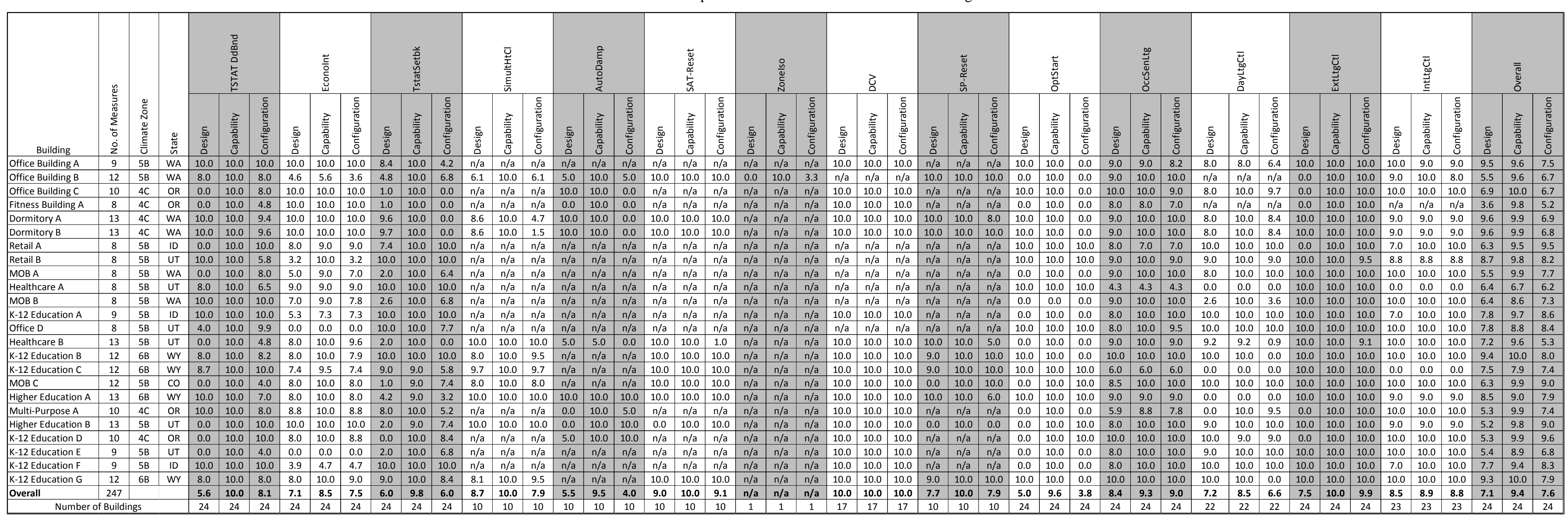





\subsubsection{Individual Building Field Results}

Figure 5 shows average compliance (design, capability, and actual configuration) for all measures by building. Significant variability in design and configuration compliance is seen across the subject building population. Overall design compliance scores range from a low of 3.6 to a high of 9.6. Likewise, configuration scores range from a low of 5.2 to a high of 9.6. Capability scores are much more clustered around higher overall compliance, ranging from a low score of 7.0 to a high score of 10.0.

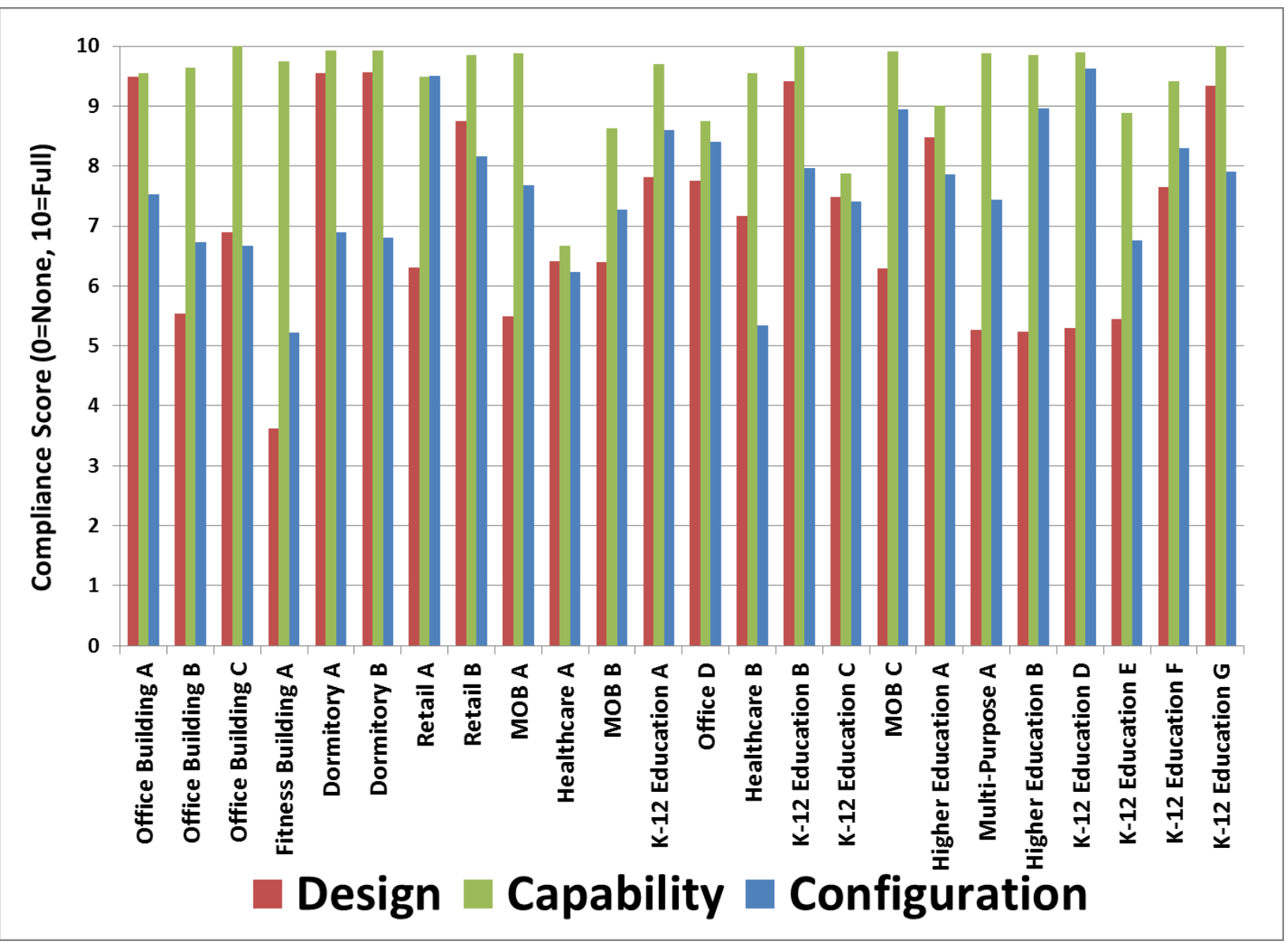

Figure 5. Average Compliance Score by Building

\subsubsection{Individual Measure Results}

Figure 6 shows average compliance score (design, capability, and actual configuration) by measure. All measures were applicable to at least ten buildings except zone isolation which was only a requirement in one of the buildings. The measures exhibiting the poorest design compliance are (1) optimal start, (2) automatic dampers, (3) thermostat deadband, and (4) thermostat setback. Those with the poorest configuration include (1) optimal start, (2) automatic dampers, (3) thermostat setback, and (4) daylighting control. Zone isolation also scored poorly on both design and implementation, but since there was only a single data point conclusions cannot be drawn. All measures showed capability 
greater than 8.4. Demand controlled ventilation was complied with for all three perspectives in every building where applicable. However, in many case (6 out of 15 applicable buildings) compliance with DCV was via an exception to the requirement.

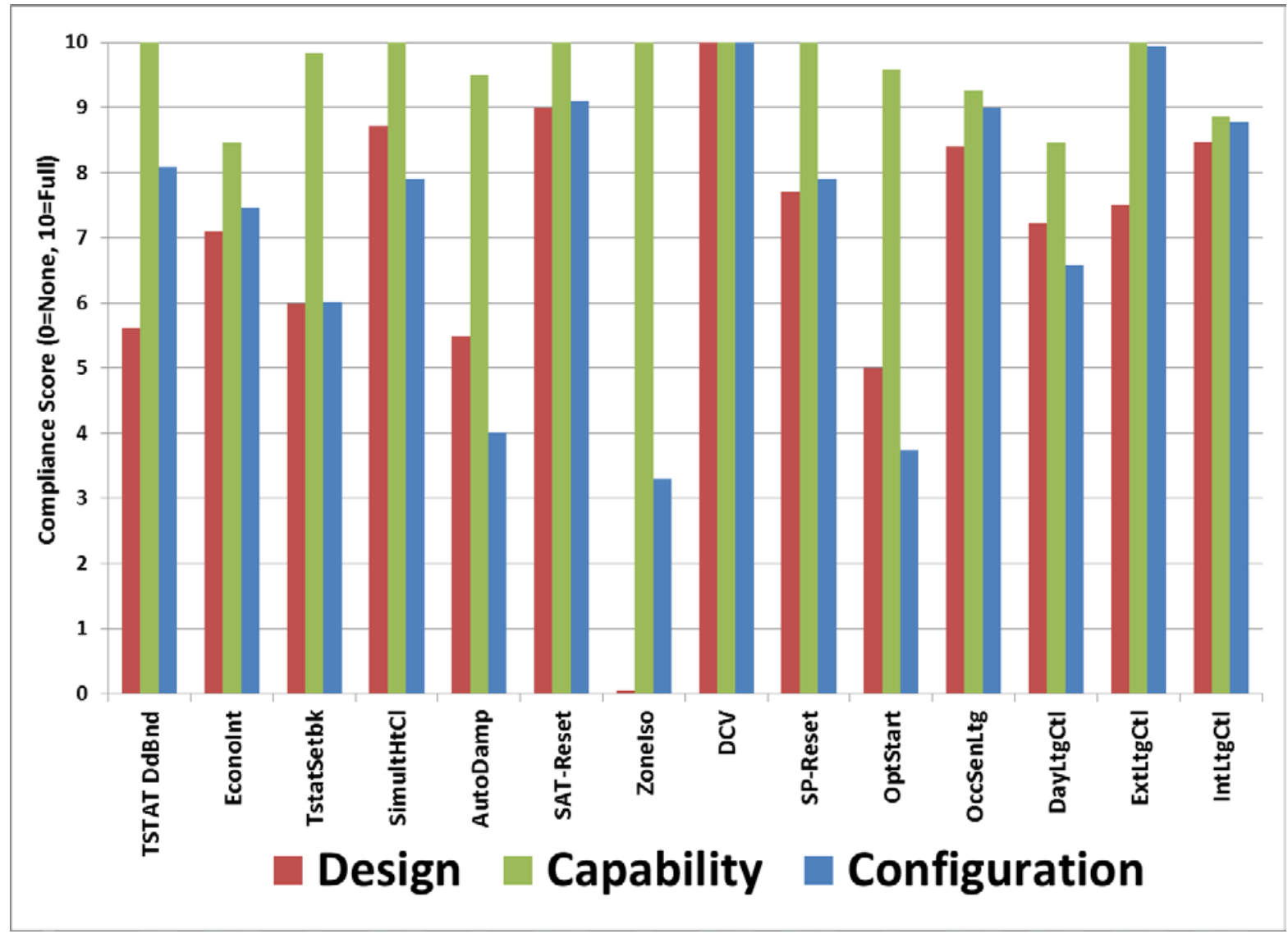

Figure 6. Average Compliance Score by Measure 


\subsubsection{Overall Results Summary}

The average measure scores are summarized in Figure 7 by control type (HVAC, lighting, overall) and perspective (design, capability, and configuration). The capability of HVAC controls are somewhat more code compliant than that of lighting. However, design and actual operating conditions associated with lighting controls tend to be more compliant than HVAC. Overall, capability of controls scores highest indicating the potential to intervene with operating buildings to improve compliance (and reduce energy use). Overall, design and configuration score at about the same level.

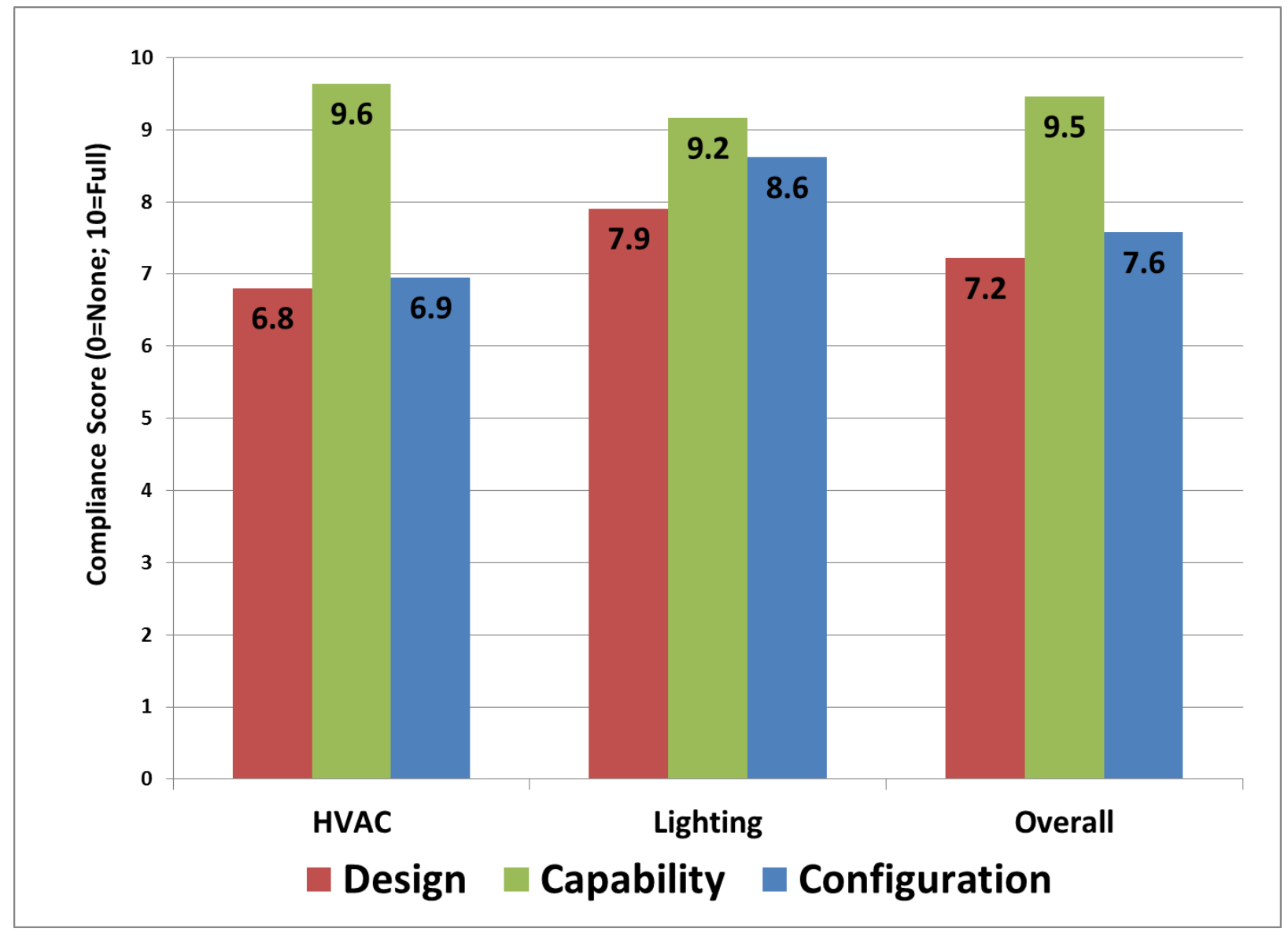

Figure 7. Average Compliance Scores by Control Type and Perspective 


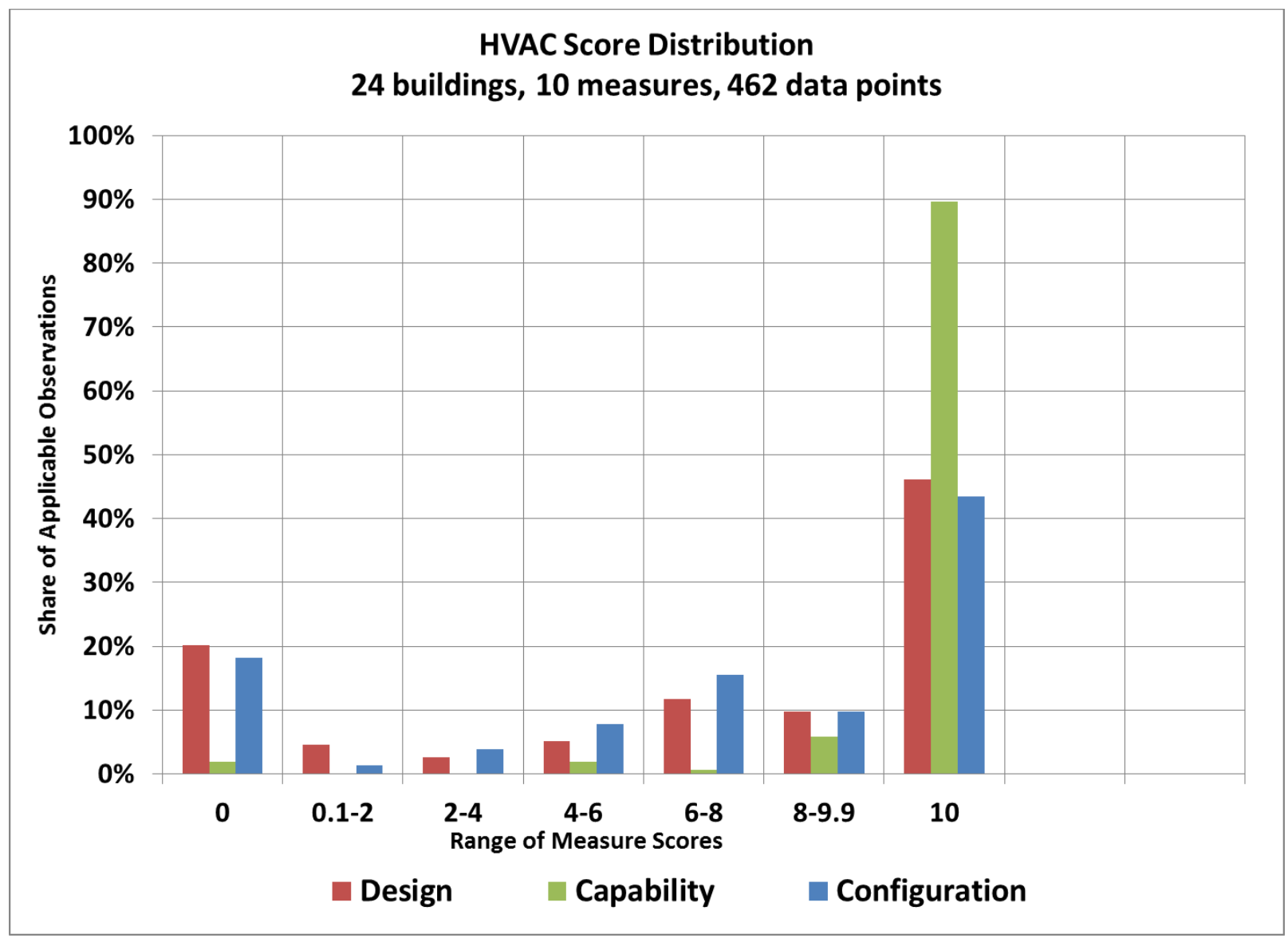

Figure 8 shows the distribution of HVAC compliance scores (design, capability, and actual configuration) for the total population sample. About $60 \%$ of the evaluated compliance data-points were scored at or above code requirements. Most non-compliant data-points exhibit some degree of compliance. About $13 \%$ of the evaluated compliance data-points exhibit no compliance. 


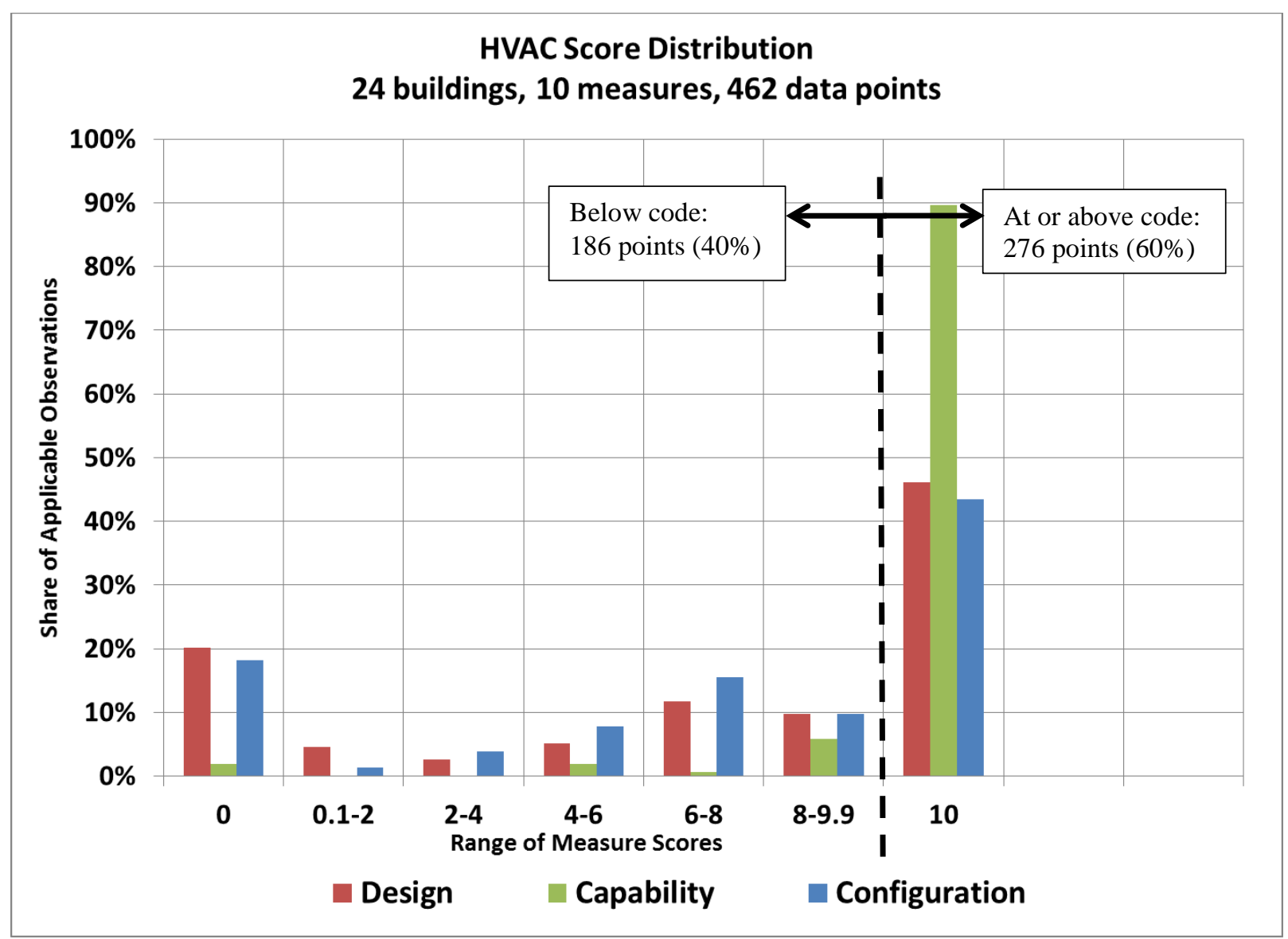

Figure 8. HVAC Compliance Score Distribution 
Figure 9 shows a distribution of lighting compliance scores (design, capability, and actual configuration) for the total population sample. About $61 \%$ of the evaluated compliance data-points were scored at or above code requirements. Most non-compliant data-points exhibit some degree of compliance. About $9 \%$ of the evaluated compliance data points exhibit no compliance.

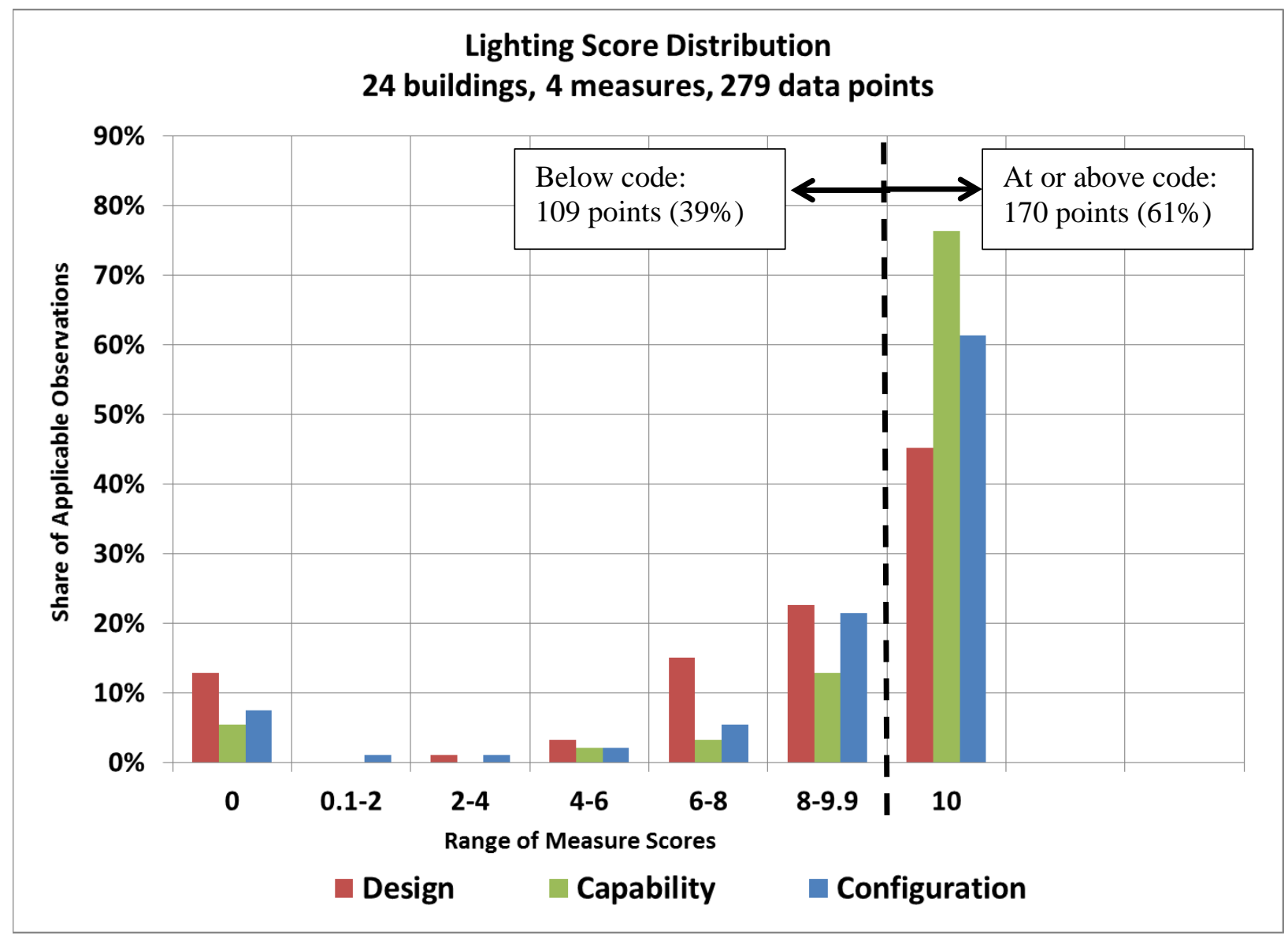

Figure 9. Lighting Compliance Score Distribution 
Figure 10 shows the overall distribution of compliance scores (design, capability, and actual configuration) for the total population sample. Approximately $60 \%$ of the evaluated code requirements were deemed compliant. About $12 \%$ of the evaluated compliance data-points exhibit no compliance. This distribution is generally similar for both HVAC and lighting.

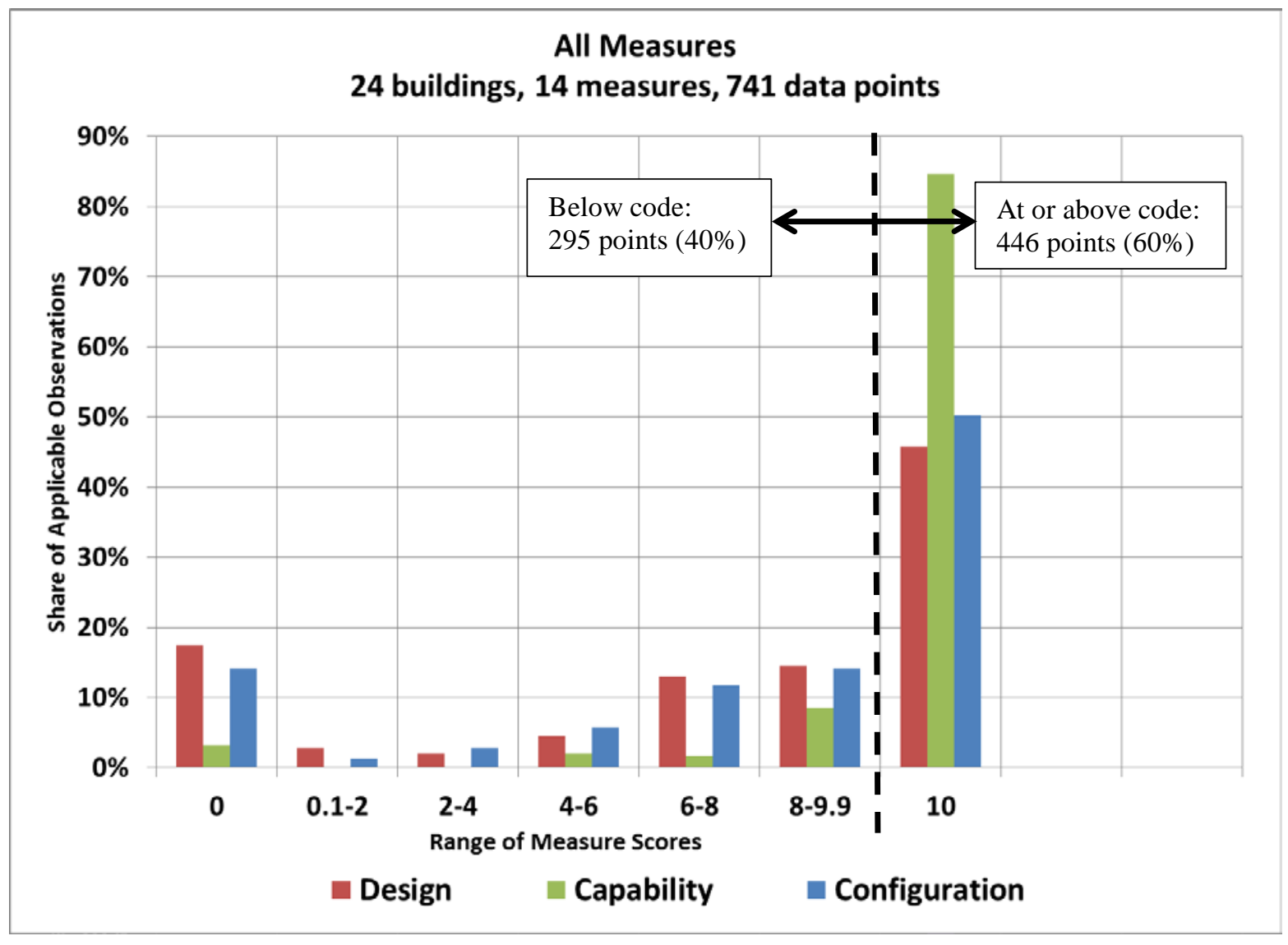

Figure 10. Overall Compliance Score Distribution 


\subsection{Analysis of Results and Impact of Controls Implementation}

The commissioning survey and field results were analyzed with the intention of answering the following questions:

1. Overall, how well are controls implemented as required by energy codes?

2. Is there a relationship between design and configuration? Is design a good predictor of quality of configuration?

3. Does the length of time between occupancy and field verification impact the results?

4. Is commissioning impactful? Does commissioning result in configuration at least as good as the design?

5. How do commissioning agent opinions of controls compliance compare with actual field compliance?

6. Which measures have low compliance?

7. On an individual control measure basis, are there differences between correct design, installed capability and actual configuration?

8. Are there regional differences in control performance?

9. What is the overall present value of lost cost savings per $1,000 \mathrm{ft}^{2}$ when controls are not operating as specified in the code?

10. Which measures are responsible for most lost cost savings?

11. What impact does commissioning have on reducing lost savings?

\subsection{Overall Performance of Energy Saving Controls}

The first step in reviewing the overall performance was to compare binary to analog compliance scoring results. In Figure 11, the percentage of field observations by measure and building is shown grouped by compliance category for each control type and perspective. This brings the results of all perspectives and control types shown in Figure 8, Figure 9 and Figure 10 onto one graph. In a binary scoring system, non-compliant results include both “Absent” items, representing complete noncompliance (characterized by a score of zero), and "Partial” items, representing partial compliance (characterized by scores between 0 and 10). Compliant results in a binary scoring system are shown by the green bars: "Full” represents full compliance (characterized by a score of ten). The yellow diamonds show the average score, as previously seen in Figure 7. In a binary scoring system, the top of the green bar represents percent compliance. In an analog scoring system, the yellow diamond represents percent compliance by score. The analog approach results in a much higher assessment of compliance and is much more representative of actual savings achieved by the energy code. 


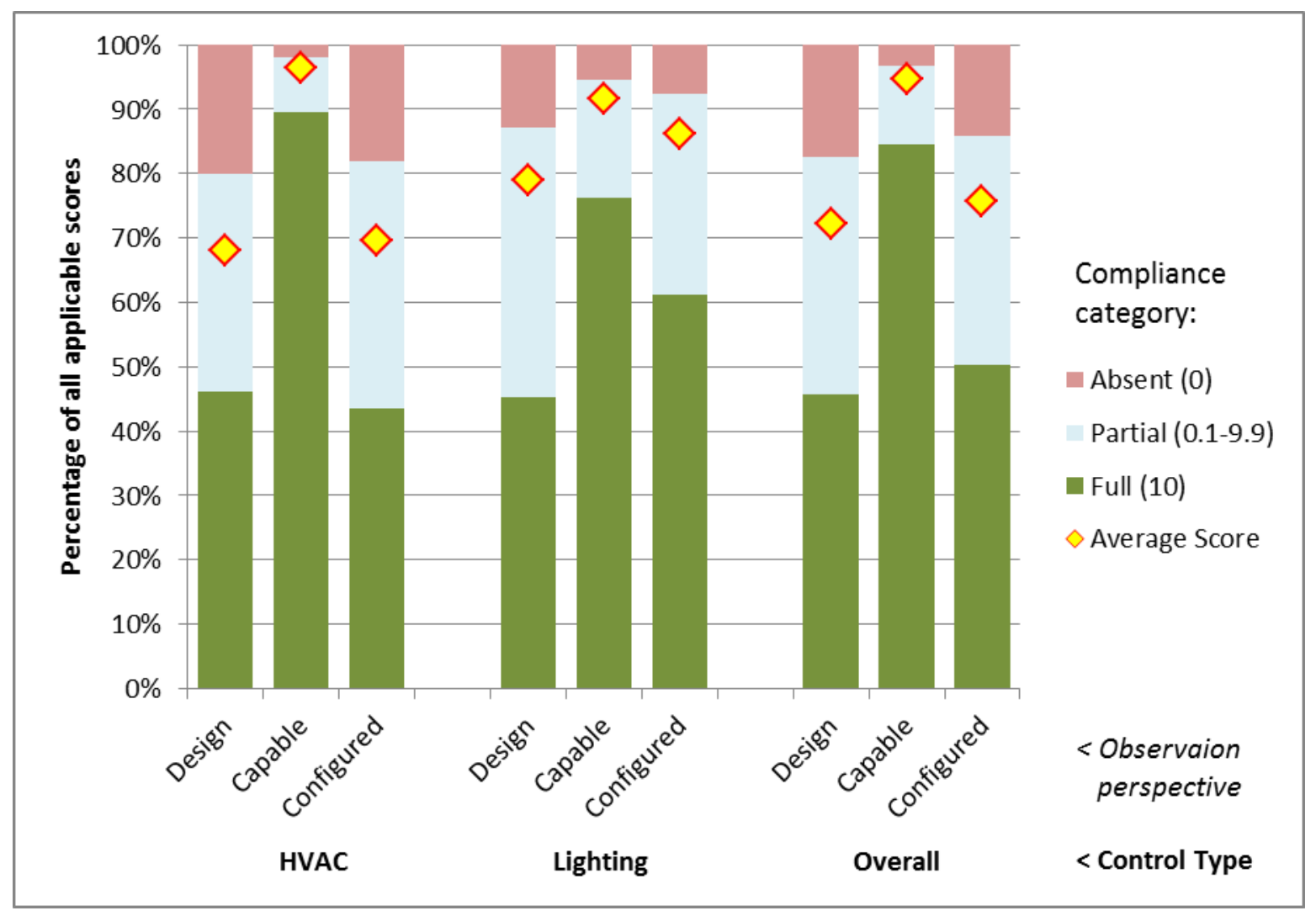

Figure 11. Field Observations by Compliance Category - By Control Type and Perspective

\subsubsection{Overall Controls Energy Code Compliance}

There were 247 field observations of total applicable measures, including 154 for HVAC controls and 93 for lighting controls. The partial scores are fairly widely spread, as shown in Figure 12, although more partial scores are in the high end of the range, lifting the average measure score and expected savings to a higher level. The partial scores shown here cover the distribution of the "partial” category in Figure 11 and results for Absent and Fully compliant scores are not shown in this figure. 


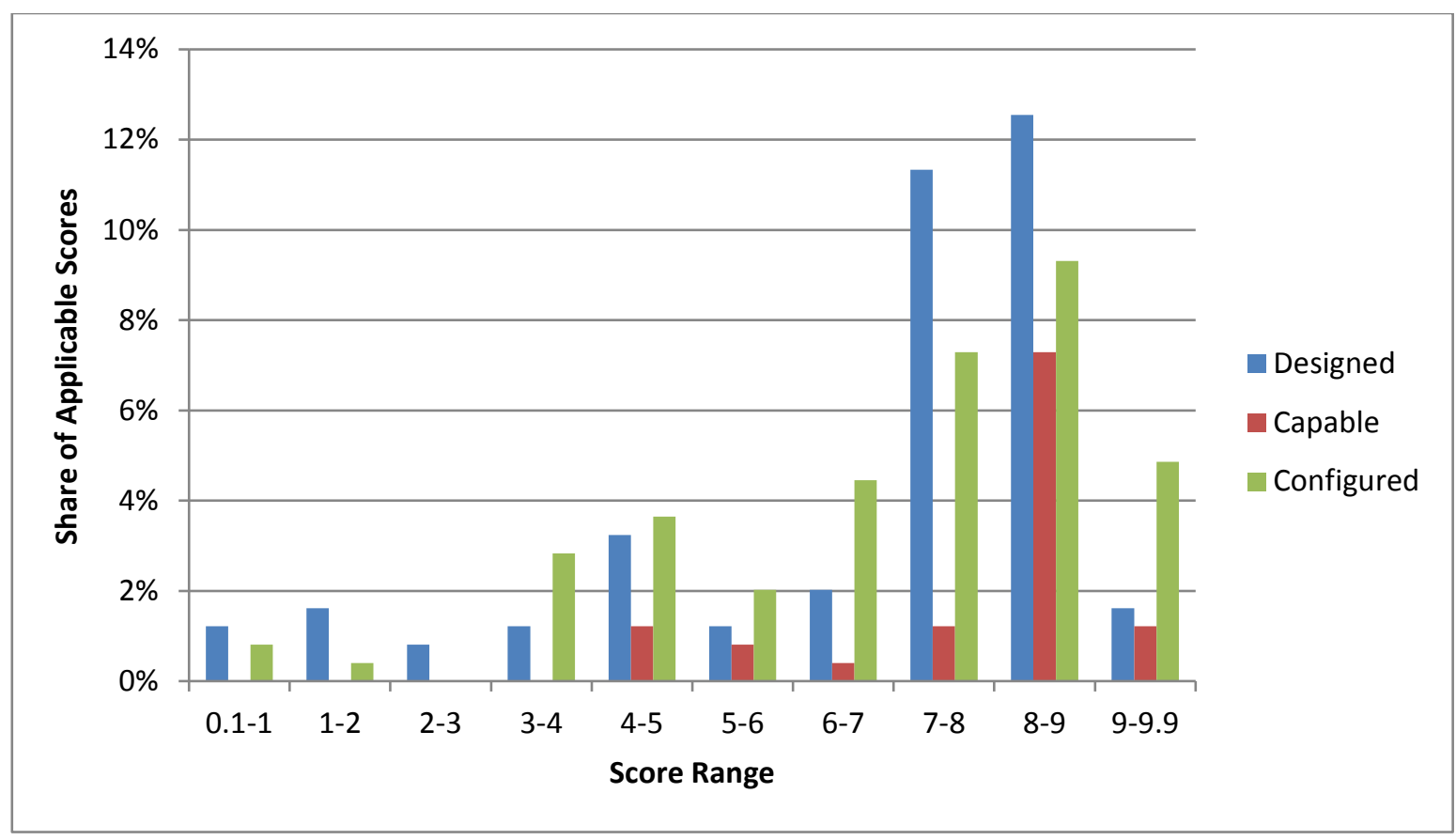

Figure 12. Partial Score Distribution, Excluding Absent (score $=0)$ and Full Compliant (score $=10)$

\subsubsection{Statistical Validation of Compliance Results}

Several statistical analyses were conducted to determine whether the pilot results could be reliably used as the basis for program actions. Highly significant results are presented in the body of the report, with secondary results and explanations included in Appendix C. The field survey collected score data for 14 measures in 24 buildings. Many of the measures only applied in some of the buildings; consequently, measure by measure data sometimes resulted in relatively small samples; therefore, it is important to know which results are likely to be repeated in a larger sample and which are inconclusive. Statistical analysis can account for the combination of sample size collected and the average differences in results for different measures or groups of measures. Where statistical analysis shows a high level of significance based on the data collected, it is reasonable to assume that the current results and conclusions are representative of what would be seen in a larger population of buildings. When the level of significance is moderate or marginal, the results should not be assumed to apply more broadly. For example, thermostat setback is shown to have low configured compliance with a high level of significance. This indicates that it would be reasonable to use the current results as a basis for actions targeted at improving compliance. On the other hand, while exterior lighting controls could be improved in some locations, the statistical results were not even marginally significant, meaning they should not be used to guide program efforts.

Because the samples in general are skewed to the high and low score and do not have a normal distribution, a robust non-parametric paired Mann-Whitney U test (aka Wilcoxon rank sum test) was used rather than a simple parametric t-test (Mann and Whitney 1947). The test calculates an estimate of the p-value or probability of the null hypothesis. The p-value indicates the level of significance, as shown in Table 7. Some may choose a standard p-value as a constant limit for significance; however, given the relative small sample size, differentiating the levels of significance and certainty relative to the tested hypothesis can be helpful to understanding the relative impact of results. Again, highly 
significant findings can be acted on immediately, while marginally significant findings may warrant further research.

Table 7. Meaning of p-value and Levels of Significance and Certainty

\begin{tabular}{llllcc}
\hline \multicolumn{1}{c}{ p-value } & Indicator & Tag & Significance & $\begin{array}{c}\text { Probability } \\
\text { of error }\end{array}$ & $\begin{array}{c}\text { Certainty of } \\
\text { conclusion }\end{array}$ \\
\hline $\mathrm{p}<0.001$ & Bold & $* * *$ & Highly significant difference & $0.1 \%$ & $99.9 \%$ \\
$0.001 \leq \mathrm{p}<0.01$ & Bold & $* *$ & Significant difference & $1 \%$ & $99 \%$ \\
$0.01 \leq \mathrm{p}<0.05$ & Bold Ital & $*$ & $5 \%$ & $95 \%$ \\
$0.05 \leq \mathrm{p}<0.1$ & Normal & $\cdot$ & Moderately significant difference & $10 \%$ & $90 \%$ \\
$0.1 \leq \mathrm{p}<0.2$ & Norm Ital & $\sim$ & Marginally significant difference & $20 \%$ & $80 \%$ \\
$0.2 \leq \mathrm{p}$ & Grey & & No significant difference & $>20 \%$ & Not \\
\hline
\end{tabular}

When comparing scores based on more than two factors, a multiple comparison test after Kruskal-Wallis was conducted (Siegel and Castellan 1988). Rather than giving a p-value directly, this test simply shows true or false (meaningful difference or no meaningful difference) at an input pvalue. Incremental runs are conducted to locate a relative significance level. The Kruskal-Wallis test is non-parametric and suitable for skewed (non-normal distribution) data like the score results in this control field study.

\subsubsection{Code Compliance of Control Measures}

Understanding which control measures are not in full compliance with code helps focus the development of code user's manuals, designer or code official training materials, and contractor or industry education programs. Table 8 shows the scores by measure for the final configuration perspective. The minimum, average and maximum scores are shown, along with the number of field observations.

To validate that the measure scores overall are indeed different from a fully compliant application, each measure was compared to the DCV measure that had 17 observations, all of which were fully compliant with the energy code. Most of the control measures investigated are shown to be significantly lower than the perfect scoring DCV measure. The exceptions found not significantly different from full compliance were exterior lighting control, zone isolation (only a single site), and supply air temperature reset. 
Table 8. Measure Compliance Scores and Statistical Significance ${ }^{\dagger}$

\begin{tabular}{lcccccc}
\hline & \multicolumn{3}{c}{ Configuration Perspective Scores } & \multirow{2}{*}{$\begin{array}{c}\text { Observa- } \\
\text { tions }\end{array}$} & $\begin{array}{c}\text { P-value vs. DCV } \\
\text { (perfect compliance) }\end{array}$ & $\begin{array}{c}\text { Signif- } \\
\text { icance }\end{array}$ \\
\cline { 2 - 3 } HVAC Measures: & Minimum & Average & Maximum & & & \\
TstatDdBnd & 4.00 & $\mathbf{8 . 0 9}$ & 10.00 & 24 & $\mathbf{0 . 0 0 1 9}$ & $* *$ \\
EconoInt & 0.00 & $\mathbf{7 . 4 6}$ & 10.00 & 24 & $\mathbf{0 . 0 0 1 9}$ & $* *$ \\
TstatSetbk & 0.00 & $\mathbf{6 . 0 2}$ & 10.00 & 24 & $\mathbf{0 . 0 0 0 5}$ & $* * *$ \\
SimultHtCl & 1.50 & $\mathbf{7 . 9 1}$ & 10.00 & 10 & $\mathbf{0 . 0 1 7 8}$ & $*$ \\
AutoDamp & 0.00 & $\mathbf{4 . 0 0}$ & 10.00 & 10 & $\mathbf{0 . 0 1 3 1}$ & $*$ \\
SAT-Reset & 1.00 & 9.10 & 10.00 & 10 & 0.50000 & \\
ZoneIso & 3.30 & 3.30 & 3.30 & 1 & N/A & \\
DCV & 10.00 & 10.00 & 10.00 & 17 & N/A & \\
SP-Reset & 0.00 & 7.90 & 10.00 & 10 & 0.0502 & $*$ \\
OptStart & 0.00 & $\mathbf{3 . 7 5}$ & 10.00 & 24 & $\mathbf{0 . 0 0 0 3}$ & $* * *$ \\
Lighting Measures: & & & & & & $*$ \\
OccSenLtg & 4.33 & $\mathbf{9 . 0 0}$ & 10.00 & 24 & $\mathbf{0 . 0 1 0 8}$ & $*$ \\
DayLtgCtl & 0.00 & $\mathbf{6 . 5 9}$ & 10.00 & 22 & $\mathbf{0 . 0 0 1 8}$ & $*$ \\
ExtLtgCtl & 9.05 & 9.94 & 10.00 & 24 & 0.5000 & $*$ \\
IntLtgCtl & 0.00 & $\mathbf{8 . 7 7}$ & 10.00 & 23 & $\mathbf{0 . 0 1 3 1}$ \\
\hline
\end{tabular}

$\dagger$ Formatting and tags to indicate significance level are shown in Table 7.

\subsubsection{Measure-by-Measure Compliance Discussion}

This section discusses measure-level code compliance; it is ordered from least compliant to most compliant measure using the configuration scores as they most directly impact building energy use. Recommendations for market intervention that may improve compliance are provided for the seven least compliant measures.

\subsubsection{Occupied Period Temperature Deadband Control (TstatDdBnd)}

Occupied period temperature deadband control requirements are being met to some degree in all subject buildings. The statistical analysis showed these results to be highly significant. Interestingly, specific requirements associated with this requirement are commonly not included in design documents. (The measure is the second least compliant measure for design.) The primary compliance deficiency relates building to systems falling short of the required $5^{\circ} \mathrm{F}$ deadband. Many subject buildings were noted to have $4^{\circ} \mathrm{F}$ deadbands $\left(70^{\circ} \mathrm{F}\right.$ heating setpoint and $74^{\circ} \mathrm{F}$ cooling setpoint). For buildings where deadband was less than required, the cooling setpoint was typically less than $75^{\circ} \mathrm{F}$. This was reported to be due to comfort needs of the occupants.

Due to this perception on the part of building operators, this measure may be difficult to ultimately achieve full compliance. Nonetheless, setpoints in all observed control systems are easily and straightforwardly adjusted. Thus the capability to achieve compliance exists in all subject buildings. 


\subsubsection{Economizer Control Integration (Econolnt)}

Economizer control was the fifth least compliant control measure. The statistical analysis showed these results to be highly significant. Primary reasons were twofold—secondary requirements associated with economizer high limit control set at $75^{\circ} \mathrm{F}$ were typically not in compliance, and a number of small cooling systems were installed without economizer capacity despite code requirements. General recommendations to improve economizer control compliance are listed below. This measure was not implemented at all in 2 out of 24 buildings where it was required.

Follow-up market recommendation:

- Require Improved Economizer Transition Control. Use of comparative control strategies that compare return air and outside air conditions generally ensure optimized economizer control. Such comparative control sequences remove the speculation about the optimal outside air high limit setpoint. Future codes should consider requiring controls capable of this strategy rather than single setpoint outside air temperature (or enthalpy).

- Ongoing Market Outreach to the HVAC Design and Construction Community. It appears there remains some confusion regarding the minimum cooling capacities that are exempt from economizer requirements with simple HVAC systems. This has been a moving target (downward) in recent code iterations. Continued communication to market players in the small HVAC construction community will increase awareness of the current requirements, and is likely to reduce the number of small systems that are not being installed with economizers.

\subsubsection{Unoccupied Period Zone Temperature Setpoints (TstatSetbk)}

Unoccupied period temperature setback was the third least compliant control measure. The statistical analysis showed these results to be highly significant. Primary reasons were twofold - a number of buildings operated the HVAC system continuously in a non-compliant manner (see discussion above) and the typical unoccupied period temperature setpoints did not achieve the code-mandated $30^{\circ} \mathrm{F}$ temperature deadband. Many operators and occupants are not comfortable with these "aggressive" setpoints ( $55^{\circ} \mathrm{F}$ for heating and $85^{\circ} \mathrm{F}$ for cooling). Most building operators standardized on unoccupied period setpoints around $60^{\circ} \mathrm{F}$ and unoccupied period cooling setpoints around $80^{\circ} \mathrm{F}$, resulting in a deadband of closer to $20^{\circ} \mathrm{F}$. Much of the savings potential for unoccupied period setback is being achieved with this level of unoccupied period control though it is important to note that this measure was not implemented at all in 5 out of 24 buildings where it was required. Note that two different implementation strategies were found: (1) situations where the fan went to a cycling mode during the unoccupied period, and less than the required setback was maintained, and (2) situations where the fan runs continuously and is not turned off. As discussed in the cost impact section, the latter case has a much higher lost savings impact. For future control compliance studies, these two cases should be separated.

Follow-up market recommendation:

- Recommendations listed under Optimal Start for market engagement also apply for this measure. The main way to improve compliance is to get unoccupied period control implemented in a larger percentage of buildings where it is applicable. 


\subsubsection{Simultaneous Heating and Cooling Limit Controls (SimultHtCl)}

Simultaneous heating and cooling control exhibited a fairly high degree of non-compliance. The statistical analysis showed these results to be significant. There were a few VAV systems where minimum air flow setpoints in terminal units have been modified significantly from the design schedules. In some cases, modification was significant and led to excessive energy use. This appears to be an issue that resides with building operators with digital control systems where minimum air flow setpoints are easily changed. It is also possible that the scheduled minimum flow setpoints were never implemented. Six out of ten surveyed commissioning agents indicated that they do not check minimum flows for adherence to design documents. Improved understanding of the functionality of minimum air flow setpoints within VAV systems is needed on the part of the building operators. Of the ten buildings in which this measure was required, only three showed full compliance and the remaining seven showed partial compliance.

Follow-up market recommendation:

Market outreach and education. Market outreach and education as discussed for several of the other measures is anticipated to ultimately reduce the amount of inappropriate operator setpoint modifications associated with individual cases of measure non-compliance.

\subsubsection{Automatic Outside Air Damper Controls (AutoDamp)}

Automatic outside air damper control was the second least compliant control measure. The statistical analysis showed these results to be significant. Primary reasons for non-compliance were twofold - (1) a number of buildings operated the HVAC system continuously in a non-compliant manner (see discussion above) and (2) many systems do not keep dampers closed during morning HVAC start-up period. This measure was not implemented at all in 5 out of 10 buildings where it was required.

Follow-up market recommendations:

- Recommendations listed under Optimal Start for market engagement also apply for this measure. The main action needed to improve compliance is to get unoccupied period control implemented in a larger percentage of buildings where it is applicable.

- $\quad$ Outreach to the HVAC design and control community. This may be useful in getting more detailed specification of morning start-up period lockout of outside air ventilation. This could include training, education, and example sequences that the control industry rates as "best practice.”

\subsubsection{Supply Air Temperature Reset Control (SAT-Reset)}

Supply air temperature reset control was essentially fully compliant on systems where required; however, statistical analysis did not find the mean score difference significant. In the only noncompliant building, the capability of the control sequence was programmed but the minimum and maximum reset setpoint limits had been modified by the building operators so that reset was not occurring. On all other buildings reset was programmed and configured so it was functioning well. Some modest education and training may address the limited non-compliance issue associated with 
this measure. In general, we do not see a need for significant market intervention to improve compliance with this measure.

\subsubsection{Zone Isolation Damper Control (Zonelso)}

Zone isolation damper control requirements were applicable to only a single building so no conclusions can be drawn. Future code compliance study efforts may want to focus on collecting data for this measure to determine whether a significant savings opportunity exists.

\subsubsection{Demand Controlled Ventilation (DCV)}

Demand controlled ventilation exhibited full compliance across 15 buildings where this measure was determined to be applicable. In six of these buildings, compliance was achieved via a codeallowed exception. Two common exceptions were use of a heat recovery ventilation system or use of multi-zone systems installed with digital controls. Interestingly, numerous additional buildings were equipped with functional DCV even where it was not required by the occupant density and air flow thresholds listed in the code. This measure appears to be well established in the HVAC control market and can be considered as common practice in new construction.

\subsubsection{Static Pressure Reset Controls (SP-Reset)}

Static pressure reset control exhibited a fairly high degree of non-compliance; however, the mean score difference was only marginally significant. Primary reasons were twofold: (1) a number of applicable systems did not even implement the control sequence correctly (even when specified), and (2) minimum and maximum reset setpoints are often adjusted by operators to effectively eliminate reset from occurring. Recommendations include potential market outreach to HVAC designers, commissioning agents, and building operators. Of the ten buildings in which this measure was required, six showed full compliance and only in one was it not implemented at all.

Follow-up market recommendations:

- Publish "Best Practices" manual for reset controls. Active recommissioning efforts across the country are assembling a significant data-set of empirical results associated with optimizing pressure reset controls in VAV systems. This information should be assembled into a focused Best Practices manual, somewhat analogous to the larger scope effort published by the California Energy Commission as the Advanced VAV Design Guide (CEC 2003). Such a manual would address techniques for establishing appropriate setpoints, discuss the energy impact of minimum pressure setpoints with a reset sequence, and identify troubleshooting and persistence practices.

- Overall outreach to the HVAC design, commissioning, and building operations communities. Providing the type of information listed above may be useful in achieving improved compliance. Commissioning of reset sequences should adopt an optimization approach rather than an approach that just verifies design intent. Designers need to clearly identify setpoint optimization requirements in both the control specifications and the testing and balancing specification sections. Building operators need to understand that effective static pressure reset can have a significant impact on electric bills, and is an important contributor to overall efficient HVAC operation for buildings that have VAV systems. 


\subsubsection{Optimal Start (OptStart)}

Optimal start control exhibits the lowest configuration compliance score of all evaluated measures and the statistical analysis showed these results to be highly significant. Non-compliance is typically due to one of two issues - HVAC system controls not including this capability at all or lack of activation of embedded optimal start algorithms within installed digital control systems. In a few instances, simple HVAC control systems were not able to effectively implement optimal start. This measure was not implemented at all in 15 out of 24 buildings where it was required.

Follow-up market recommendation:

- Engage commissioning and building operations community to provide training and education about occupied/unoccupied HVAC control. There is a significant and persistent belief in the building operations community that stopping and starting HVAC systems results in increased energy costs. In several of the subject buildings, this reasoning was offered as the underlying reason for continuous operation. Poor experiences in achieving effective building warm-up in the past has also created a perception among building operators that optimal start just doesn't work. Education and training have the potential to improve awareness and code-effective operation associated with both of these issues.

\subsubsection{Occupancy Sensor Lighting Control (OccSenLtg)}

Occupancy sensor installations were observed to be reasonably compliant across the sample building population. The mean score results were statistically significant. Compliance where occupancy sensors were required was excellent with most interior lighting fixtures now being equipped with occupancy sensors that are functional. In cases where a degree of non-compliance was noted, it almost always was associated with sensors that were not set up as vacancy sensors, or "manual on" control (in spaces where the codes designate this mode of control). Vacancy sensing control mode results when a sensor is set up in a "manual on-auto off" mode of operation. Many lighting designs did not specifically call out the fixtures where this was required. Some of these sensors ended up installed in an "auto on-auto off" mode of operation. All sensors observed have the capability to be reconfigured in the field to function in vacancy sensor mode. This measure was required in all 24 buildings and was perfectly compliant in 13 of them.

While the energy impact is minimal, it is recommended that some outreach be considered to the lighting design community to encourage a higher level of uniform detail to be delivered in lighting designs. The most complete lighting designs reviewed as part of this effort were excellent, and contained complete detailed information on all code requirements. The least compliant designs lacked most of the corresponding detail seen in the best documents. This was particularly true of the vacancy sensing requirement.

\subsubsection{Daylighting Controls (DayLtgCtl)}

Daylighting controls exhibits the fourth lowest configuration score of all evaluated measures. These results were found highly significant by the statistical analysis. This is typically due to partial or complete elimination of the required daylighting control scope of work from the project. This is occasionally represented as missing design information that carries forward into the construction, but 
is often a change made during construction. Another reason for poor compliance relates to lack of fully functional daylighting controls. This appears to be a deficiency resident in the construction and commissioning industries. It was common to see installed daylighting control components that did not work or worked at a sub-optimal level. This measure was not implemented at all in 5 out of 22 buildings where it was required.

Follow-up Market recommendations:

- Document daylighting zones in the architectural drawings. Work with code enforcement agencies to provide training and resources to make sure this is occurring appropriately. Many documents identified some but not all of the code-required daylighting zones.

- Document setpoint and control sequence on architectural drawings. Include detailed setpoint and control sequence information in the lighting control specifications, directly on the lighting drawings or, at a minimum, as required information to be submitted prior to equipment ordering. These include but are not limited to: (1) type of lighting control per daylight zone (stepped or dimming control), (2) maintained illuminance setpoint, (3) control points list, and (4) control sequences of operation. Daylighting controls are as complex as many HVAC control sequences. The design and pre-construction submittals should therefore include the same level of information as typically required for HVAC controls.

- Improve Authority Having Jurisdiction review and approval during permitting. Several projects simply did not include required daylighting controls in the design documents. This lack of coderequired scope of work should be flagged during plan review. Additional training and review resources should be considered for agencies having responsibility for review of permit documents. A special emphasis needs to be placed on daylighting control information.

\subsubsection{Exterior Lighting Control (ExtLtgCtl)}

Exterior lighting control requirements were essentially fully compliant across the sample building population. The mean score difference was not found to be significant. Buildings employed either photocell-based control or astronomical timeclocks as compliant control technology. In two instances, a minor amount of the exterior lighting load (wattage) was observed to be exhibiting non-functional control. This was the result of "broken" control components. As seen in the metrics reported in Section 5 , this amounted to $2 \%$ of the total connected and controlled exterior lighting load. In general, we do not see a need for significant market intervention to improve compliance with this measure.

\subsubsection{Automatic Interior Lighting Control (IntLtgCtl)}

Automatic interior lighting control compliance can be met by occupancy sensors, timer controls, or a combination of both. For this project, occupancy sensor controls were evaluated separately, so compliance for this measure translated to the degree to which central timer controls were installed to satisfy automatic control of light fixtures that were not installed with occupancy sensors (and were required by code to be controlled). For the most part, subject buildings installed effective and operational timeclock controls. The mean score was found to be statistically significant. In the few buildings that did not achieve compliance, the primary reason was the complete lack of central 
timeclock system installation. (Even in these buildings, selected fixtures were equipped with occupancy sensors). In these cases, lack of timeclock control appears to be an experience-based owner preference. This seems to be a minority of buildings with the majority of buildings exhibiting impressive compliance. Of the 23 buildings in which this measure was required, 14 showed full compliance and only in two was it not implemented at all.

\subsection{Secondary Statistical Results}

As a pilot study, the sample was not large enough to reach robust conclusions in several areas. The results, even with a lower level of statistical power, can indicate where future work can be focused, especially in training for control systems design or inspection. The detailed analysis for these results is included in Appendix $\mathrm{C}$, with a high level summary in this section.

\subsubsection{Relationships of Perspectives and Time Lag}

Interesting questions can be resolved by comparing the scores of design, capability, and configuration. There is also some impact of time lag from occupancy to field audit. Analysis of these objectives raises several questions and possibilities for future research:

- If design and configuration scores are the same, then it may be possible to determine energy code compliance just by reviewing the plan submittal without visiting the building.

- If capability scores are significantly higher than design scores, it may indicate that product manufacturers or contractors are aware of code provisions, and provide equipment that is capable of meeting code, even if not specifically called out in design documents. Most general provisions in design documents have a general statement that installations shall meet applicable codes. A further benefit of high capability scores is that later tune-up efforts can bring a building into code compliance or that outcome based building energy management efforts have a good chance of success.

- If capability scores are significantly lower than design scores it may indicate a need for better training of controls contractors, enhanced commissioning, or both. A review of the detailed site results found that only occupancy sensor control in Retail A had a lower capability score than design.

- If configured scores are significantly lower than capability scores, it may indicate that there is not a concerted effort either in the design, installation or commissioning work to specifically call out setpoints, schedules or other subtle code requirements. There may also be cases where, due to a time lag from installation/occupancy and the field audit, building occupants or managers have changed the setpoints. Some may even argue that the code only requires capability of controls rather than proper configuration. Recent code change efforts (90.1-2016 and 2018 IECC) have added the words "configured to" where control provisions call for certain setpoints; however, these updated codes were not in effect for the buildings in this field study.

- If there is a strong impact of time lag between occupancy and the field audit, then future studies may want to more strictly manage this time lag. 


\subsubsection{Overall Relationship between Perspectives}

The overall relationship between the perspectives (design, capability, and configuration) measured is shown in Table 9 on a group basis. The group average score is shown for each perspective and the differences between perspective average scores is shown. A multiple comparison test after Kruskal-Wallis is conducted with incremental thresholds of $\mathrm{p}<0.2$ and $\mathrm{p}<0.1$ to find the significance of the differences in perspective group average scores.

As can be seen in Table 9, the overall scores at the design and configuration perspective are not significantly different for HVAC and measures as a whole. The lighting measures are different from design to configuration. The capability scores are significantly different from scores for both the design and configuration perspectives, except for lighting. This may indicate that:

- Configured compliance might be inferred on average overall or for HVAC measures based on review of design documents.

- Manufacturers and contractors are aware of code provisions not specifically called out in design documents and provide most equipment with the capability of meeting code, as the capability group scores are all higher than the design scores.

- Building controls are not configured to meet code requirements in many cases, or have been reconfigured during building occupancy after project completion. Since controls are generally capable of achieving a higher compliance score than is actually achieved, more specific design detail around setpoint requirements or contractor and building manager training may result in higher configured scores.

- Building controls can benefit from post-occupancy building tuning or recommissioning efforts aimed at improving energy efficiency of the building, since the configured scores are lower than the capability.

Table 9. Difference in Perspective Average Compliance Scores

\begin{tabular}{lcccccc}
\hline & \multicolumn{2}{c}{ Group Compliance Average Scores } & \multicolumn{3}{c}{ Perspective Differences in Scores ${ }^{\dagger}$} \\
Group & Design & Capability & Configuration & Design to & $\begin{array}{c}\text { Design to } \\
\text { Capability }\end{array}$ & Configuration \\
Configuration
\end{tabular}

$\dagger$ Boldface indicates that the difference between perspectives is at least moderately significant at $\mathrm{p}<0.1$, while a grey score difference is not significantly different, $\mathrm{p}>0.2$. 


\subsubsection{Control Measures Compliance Variation by Perspective}

Overall, the preceding analyses showed that configuration is generally better than design compliance and that configuration is lower than capability. However, individual measures may show differences from the overall trend. Understanding the perspective differences of individual measures will allow remediation activities to be better targeted. The details are analyzed further in Appendix C and high level observations are summarized below:

- Only four measures had a significant difference from the design to configured score, all of which had higher configured scores: thermostat deadband, economizer control), occupancy sensor lighting and exterior lighting control. This may indicate that contractors have a good understanding of the code requirements for these measures.

- For most measures the difference between design and capability was positive and significant. In no case was the measure capability average score below the average design score. This indicates that suppliers, contractors, and/or commissioning agents are implementing control capability when required by code, even when not explicitly included in the design.

- The drop in score from the capable to configured perspective was significant or marginally significant in all cases except supply air temperature reset, DCV, and interior lighting time control (zone isolation is excluded with only one observation). Final configuration would likely improve with more specific setpoint or sequence guidance in design documents or from commissioning agents having a clearer mandate to configure controls to match the setpoints called for in code.

\subsubsection{Using Design Compliance as a Proxy for Configured Compliance}

One of the open questions related to reducing the costs of compliance studies is whether overall compliance can be determined based on a review of design documents without field verification? This would obviously reduce the cost of commercial compliance studies. The sample is not large enough to arrive at a definite conclusion; however, the more detailed analysis in Appendix C has some indicators for future research.

Based on the analysis of this limited sample in Appendix C, it can be concluded that final configuration compliance cannot be inferred on a measure specific basis from the design perspective compliance, at least not for most control measures. It may be possible to infer overall building control compliance based on design score, but it would take a much larger sample to verify that approach for a particular mix of measures. Seeing the difference in perspective compliance can help direct training or enforcement activities where they will have the most benefit. Overall, preliminary conclusions related to using design scores as a proxy for final compliance are:

- It appears that design can be used as a proxy for configuration scores on an overall building basis given a $\pm 10 \%$ equivalence band in scores.

- Generally, there are significant, if small, increases between design and configuration scores on most measures. In no cases are reductions in score from design to configuration found to be significant. There are cases where the increases in score are not significant, so a larger sample may reveal measures that do have score decreases. 


\subsubsection{The Impact of Time Lag on Configured Results}

Configured conditions could be affected by changes made between the time the building was occupied and the audit completed. As discussed in Section 1.1.1 the energy code compliance process typically ends once a jurisdiction issues a certificate of occupancy. Therefore if judgements of compliance are to be made it needs to be determined if site assessments conducted up to two years after occupancy are a good indicator of measure condition at the time the building was first occupied. The audit lag in this study ranged from -1 month (inspected just before occupancy) to 27 months after occupancy, with a median of 4 months and an average of 7 months.

An analysis was made by dividing the buildings into groups based on lag time from occupancy to audit. Short ( $<4$ months), Medium, and Long ( $>10$ months) lag groups were established based on the time in months from occupancy to field audit. Statistical analysis detailed in Appendix C showed a marginally significant reduction in average score with increasing lag. While these results somewhat support the idea that delay in compliance evaluation should be restricted, the sample is too small to provide definite recommendations.

\subsubsection{Geographic Impact on Compliance Scores}

Different states and jurisdictions have a difference in code enforcement, design approach, construction approach, commissioning practices, energy awareness, and building operation. While a raw comparison of average compliance scores showed moderate differences from state to state, a statistical analysis showed no cases for this data set that were significantly different.

\subsection{Impact of Commissioning}

The impact of commissioning on compliance has been investigated for lighting and HVAC controls as groups and for individual measures.

\subsubsection{Overall Impact of Lighting and HVAC Commissioning}

For all the buildings, evidence of commissioning for lighting and HVAC was sought and the building flagged for commissioning by system. The impact of commissioning on configured perspective measure scores can only be evaluated for those measures that were present in both commissioned and non-commissioned buildings. Some HVAC measures were always commissioned and therefore were not included in this evaluation. There were no lighting measures that were always commissioned. The number of measures and their average configured scores are shown by group in Table 10. Statistical testing found the impact of HVAC commissioning on the measure scores was marginally significant, while the lighting commissioning was not found to have significant impact. 
Table 10. Overall Commissioning Impact, Kruskal-Wallis Multiple Comparison Test $^{\dagger}$

\begin{tabular}{lccccccl}
\hline & \multicolumn{4}{c}{ Sample Size, $\mathbf{n}$} & \multicolumn{2}{c}{ Average of Configured } & \multicolumn{2}{c}{ Pass Test } & \\
Area & No Cx & $\mathbf{C x}$ & No $\mathbf{C}$ & $\mathbf{C x}$ & Delta & $(\mathrm{p}<0.2)$ & Conclusion \\
\hline HVAC & 24 & 99 & 5.74 & 6.87 & +1.13 & TRUE & Marginally significant at $p<0.2$ \\
Lighting & 26 & 67 & 8.30 & 8.73 & +0.43 & FALSE & Difference not significant \\
\hline
\end{tabular}

${ }^{\dagger}$ Formatting to indicate significance level is shown in Table 7.

\subsubsection{Measure Level Impact of Commissioning}

A further analysis of commissioning impact was conducted at the measure level. The results are shown in Appendix C. While HVAC commissioning was found to have a significant impact overall on configured scores, only one measure (occupancy sensor lighting) showed significant impact from commissioning, while three measures (thermostat setback, automatic outside air dampers, and optimum start) have only a marginally significant impact. A larger sample size that included more buildings without commissioning would provide more insight into the impact of commissioning. It is worth noting that in all cases where there was some significance, commissioning improved the energy impact.

It may be that improved design specifications around setpoints required by code will increase the attention of commissioning agents to these measures. This is supported by the previously discussed feedback received from commissioning agents that code-required measures were not commissioned unless included in the design.

\subsubsection{Commissioning Agent Opinion Comparison}

Section 3.2 includes commissioning agents' opinions of how individual measures are implemented in the field, both from a capability and final configuration perspective. Their average opinions are compared with the actual field audit findings in Figure 13. To allow comparison, scores from 0 to 10 are converted to a compliance range of $0 \%$ to $100 \%$. Reviewing the situations where the opinion was more than $25 \%$ different from the observed field condition found the following:

- In the area of actual final configuration, commissioning agents overestimated (difference of more than 25\%) results for four measures: outdoor air damper, thermostat setback, zone isolation, and optimum start. The worst controls measures from a configuration standpoint were automatic dampers and optimal start with configured scores of $40 \%$ and $38 \%$ respectively; yet commissioning agents reported correct configuration after commissioning of $87 \%$ and $78 \%$ respectively. This indicates that either commissioning agents do not understand the correct implementation of these measures or that building operators are overriding them post-commissioning.

- In the area of actual final configuration, they underestimated (difference of more than 25\%) results for two measures: thermostat deadband and simultaneous heating and cooling. Thermostat deadband was shown to have an average configured score of 8.1, while commissioning agents put compliance down at only 56\%. Limits on simultaneous heating and cooling was shown to have an average configured score of $79 \%$, but commissioning agents put compliance down at only $10 \%$. The commissioning agent responses need to be viewed 
with some skepticism, as none of the commissioning agents indicated that they verify limits on simultaneous heating and cooling for VAV systems, so it is difficult to understand how they conclude that this measure is correctly implemented only $10 \%$ of the time. These findings indicate that most designers and contractors are correctly implementing the measure without the benefit of commissioning.

Commissioning agents had mixed responses to whether or not contractors implement controls requirements in design documents (2 yes, 2 no, 4 mixed). However field results show that when included in design, most controls measures do get implemented properly. Other observations include:

- Six of ten commissioning agents indicated a need for better energy code training of design engineers and an overall average design score of 7.2 confirms that.

- Commissioning agents estimate that $79 \%$ of the 14 high-impact control strategies are operating in compliance with code requirements at the completion of commissioning and field data supports that with an average configuration score of $76 \%$ for all measures.

- Commissioning agents estimate an average of only $41 \%$ of the 14 high-impact controls measures are specified correctly, but review of actual design documents indicates higher design compliance with an average score of $72 \%$.

The most important take away from this comparison is an indication that the impact of commissioning activity on temperature setback and HVAC scheduling needs to be greatly improved. Daylighting, optimum start, and outside air damper controls will likely also benefit from improved commissioning support that is more focused on energy code compliance. 


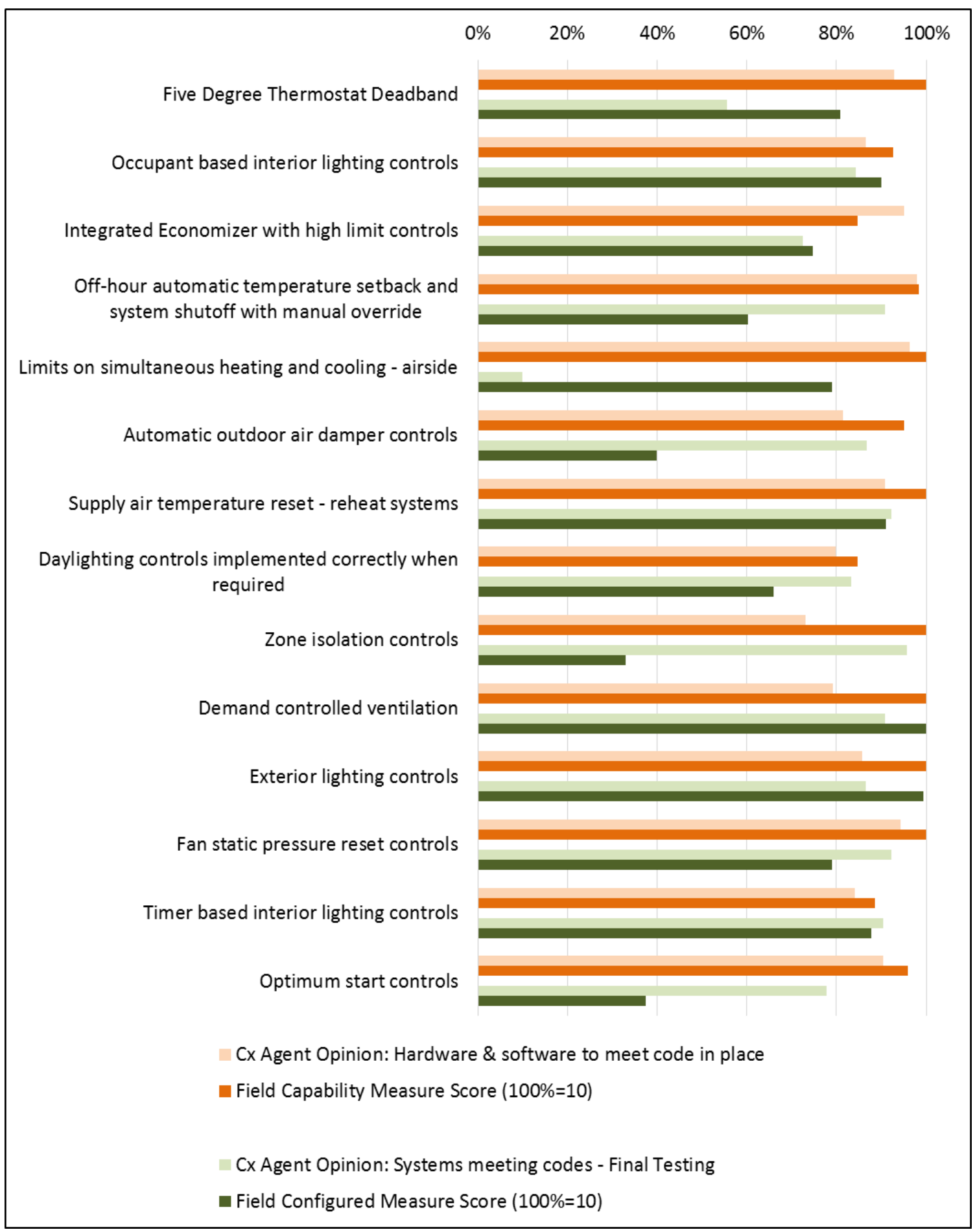

Figure 13. Comparison of Commissioning Agent Opinion to Field Conditions 


\subsection{Cost Impact Analysis}

The previous sections described the condition of 14 of the most impactful energy code-required controls in 24 newly constructed buildings. Through site inspections it was determined how each of those controls was operating compared to the requirements described in the code. The logical question to answer is: What is the energy or energy cost impact of the variation between how these buildings are being operated and the code specifications? An earlier PNNL study looking at code compliance in small office buildings included extensive simulation to develop energy cost values for each code measure based on the conditions found in the field (Rosenberg et al. 2016); however, that study only included a single climate zone and did not cover many of the 14 high-impact control requirements investigated in this research. Results from that study are used here primarily for lighting measures that do not have a large variation in savings by climate zone, with costs also used for economizer integration and thermostat setback. For the remaining measures, data from a previous study of the energy impact of retuning measures that provides useful national office building cost savings information is used (Fernandez et al. 2012). This information is calculated for all U.S. climate zones and weighted by U.S. climate zone construction to establish the unit lost cost savings used in this study. Although both sets of data are for office buildings, those savings are applied to other building types, as detailed lost savings data on medical, retail, and educational facilities was not available. While building specific costs would be more accurate, this cost impact estimate is intended to be an indicator of compliance value, not a precise estimate. Table 11 shows for each control measure the lost energy cost savings if the measure is not implemented, the metric that cost is applied to, and the source of the savings assumptions.

The lost cost savings are a rough indicator of overall lost cost savings due to the differences between the buildings' actual operation compared to the operations described in the code. Therefore, the results are based on the measure configuration compliance scores developed during the field investigation. A score of 10, indicating full compliance, received no cost penalty, while a score of 0 received a maximum cost penalty relative to the applicable building area. Scores in between were assigned a linear partial lost savings based on score. Section 4.1 describes the protocol for assigning scores for each measure.

Some of the measures used as lost energy cost data sources were not exact matches for the measures investigated in the field, but they were close and determined appropriate to provide an indicator of potential lost savings. For example, the retuning study did not have a measure for no time control, but had a measure for 4-hour daily optimum stop, assuming the system operated well into the partially occupied evening. This measure was thought to be close enough to provide the proper cost indicators. Another measure that was not exact was application of the retuning daily one-hour increase in closed outside damper operation, vs. the field measure indicating improper outside damper operation that would likely result in greater lost savings. Both of these simplifications are conservative in that the likely result is less cost savings than actually would occur. 
Table 11. Annual Lost Energy Cost Savings and Source

\begin{tabular}{|c|c|c|c|}
\hline Measure & $\begin{array}{c}\text { Lost Cost Savings } \\
\text { (\$/Unit-yr) }\end{array}$ & Unit & $\begin{array}{c}\text { Lost Savings Cost } \\
\text { Source } \\
\end{array}$ \\
\hline \multicolumn{4}{|c|}{ HVAC Measures: } \\
\hline TstatDdBnd & $\$ 62$ & Thousand $\mathrm{ft}^{2}$ & Fernandez 2012 \\
\hline EconoInt & $\$ 33$ & Cooling Ton & Rosenberg 2016 \\
\hline TstatSetbk & $\$ 176^{*}$ & Thousand $\mathrm{ft}^{2}$ & $\begin{array}{l}\text { Fernandez } 2012 \& \\
\text { Rosenberg } 2016\end{array}$ \\
\hline SimultHtCl & $\$ 106$ & Thousand $\mathrm{ft}^{2}$ & Fernandez 2012 \\
\hline AutoDamp & $\$ 544$ & Thousand cfm OA & Fernandez 2012 \\
\hline SAT_Reset & $\$ 47$ & Thousand $\mathrm{ft}^{2}$ & Fernandez 2012 \\
\hline ZoneIso & $\$ 44$ & Thousand $\mathrm{ft}^{2}$ & Fernandez 2012 \\
\hline $\mathrm{DCV}$ & $\$ 87$ & Thousand $\mathrm{ft}^{2}$ & Rosenberg 2016 \\
\hline SP_Reset & $\$ 65$ & Thousand $\mathrm{ft}^{2}$ & Fernandez 2012 \\
\hline OptStart & $\$ 31$ & Thousand $\mathrm{ft}^{2}$ & Fernandez 2012 \\
\hline \multicolumn{4}{|c|}{ Lighting Measures: } \\
\hline OccSenLtg & $\$ 43$ & Thousand $\mathrm{ft}^{2}$ & Rosenberg 2016 \\
\hline DayLtgCtl & $\$ 24$ & Thousand $\mathrm{ft}^{2}$ & Rosenberg 2016 \\
\hline ExtLtgCtl & $\$ 473$ & kW Exterior Light & Rosenberg 2016 \\
\hline IntLtgCtl & $\$ 373$ & Thousand $\mathrm{ft}^{2}$ & Rosenberg 2016 \\
\hline
\end{tabular}

*Thermostat setback lost savings assumes that fan is running continuously during unoccupied hours. If the fan cycles only as needed to meet thermal loads, lost savings is only $\$ 13 / \mathrm{kft}^{2}$.

The following caveats should be applied to review or use of the cost results, and it should be remembered that the cost analysis is intended to provide a general indicator of cost impact, not a precise projection of impact on a certain set of buildings. The following potential issues exist in the lost energy cost savings development:

- While the sample represents a good mix of building types and sizes, the sample is small and the overall sample scoring (representing code compliance) does not likely match a larger population of interest.

- Lost savings are based on office building occupancies and are not likely to match the full range of building types in the sample or in a target population. The office prototype from the tuning study is a "post-1980" office building that is different from a building meeting current codes (Fernandez et al. 2012). Because the building envelope has lower insulation, lighting power is less, and there is lower efficiency HVAC equipment in the older buildings examined in the retuning study, overall savings is expected to be less as well. Based on a reduction in energy use of code-compliant office buildings of 25\% between 2004 and 2013 (Thornton et al. 2011), the retuning study savings were discounted by $25 \%$ for the current analysis.

- While the unit cost savings data match generally to the HVAC system types in the field buildings (VAV measures were applied to VAV systems), the mix of HVAC systems in this sample is unlikely to match the mix in a target population. 
- Building loading and use for the sample set may not be similar to the simulated buildings in the cost data sources, and the distribution of building loading may not be similar to the general population of buildings.

- The scoring used in this field study is not precisely linear with cost, unlike the scoring used in the pilot methodology for compliance (Rosenberg et al. 2016). However, the endpoints are properly matched, that is a score of 0 in the field test does match the worst case lost savings, while a score of 10 indicates there were no lost savings.

Many of these issues impact the overall and average results for the field test. If the sample was larger and there was more extensive cost impact data available across both climate zones and building types, then cost impact results could be weighted to match an expected population in particular states or jurisdictions. While such weighted projections have not been made here, the compilation of lost savings results are at least intended to give an indication of what the impact of improved compliance through better design or implementation would be.

\subsubsection{Overall Lost Cost Savings}

Lost energy cost savings are shown on a building basis and for the overall sample in Table 12. The lost energy cost savings per year were developed (with caveats) as previously described for each building. These lost savings are shown per building and per thousand square foot annually. Also shown is the present value of the lost energy savings over the life of the measures, assumed to be 15 years for controls measures. To account for the time value of money, future savings are discounted using a real discount rate of 3.0\% with a factor accounting for escalation of energy prices faster than general inflation. Using a simplified method of projecting life-cycle value of savings, a uniform present value factor ${ }^{1}$ is applied to the annual savings to reflect the discounted value of savings over the measure life. This approach generally follows the methodology established by the Federal Energy Management Program for federal building energy projects (Lavappa and Kneifel 2015). This calculation demonstrates the value of lost energy cost savings assuming the current controls configuration will remain as is for 15 years which may not be the case for all measures.

\footnotetext{
${ }^{1}$ Uniform present value factors are pre-calculated factors used to project the present value of annually recurring energy costs based on measure life, current DOE discount rates and projected energy price escalation rates that are variable during the measure life, as determined by DOE’s Energy Information Administration.
} 
Table 12. Lost Energy Cost Savings Overall and by Building

\begin{tabular}{|c|c|c|c|c|}
\hline Building & Lost Savings (\$/yr) & $\begin{array}{r}\text { Building floor } \\
\text { area }\left(\mathbf{f t}^{2}\right)\end{array}$ & $\begin{array}{r}\text { Lost Savings } \\
\text { (\$/thousand } \mathbf{f t}^{2} \text {-yr) } \\
\end{array}$ & $\begin{array}{r}\text { Present Value } \\
\text { Lost Savings } \\
\left(\$ / \text { thousand } \mathbf{f t}^{2}\right) \\
\end{array}$ \\
\hline Office Building A & $\$ 637$ & 14,195 & $\$ 45$ & $\$ 565$ \\
\hline Office Building B & $\$ 10,545$ & 24,000 & $\$ 439$ & $\$ 5,541$ \\
\hline Office Building C & $\$ 4,625$ & 19,000 & $\$ 243$ & $\$ 3,069$ \\
\hline Fitness Building A & $\$ 5,657$ & 10,300 & $\$ 549$ & $\$ 6,926$ \\
\hline Dormitory A & $\$ 24,174$ & 113,195 & $\$ 214$ & $\$ 2,693$ \\
\hline Dormitory B & $\$ 45,534$ & 219,910 & $\$ 207$ & $\$ 2,611$ \\
\hline Retail A & $\$ 126$ & 16,250 & $\$ 8$ & $\$ 98$ \\
\hline Retail B & $\$ 9,789$ & 124,000 & $\$ 79$ & $\$ 996$ \\
\hline Medical Office A & $\$ 965$ & 13,000 & $\$ 74$ & $\$ 936$ \\
\hline Hospital A & $\$ 651$ & 10,500 & $\$ 62$ & $\$ 781$ \\
\hline Medical Office B & $\$ 859$ & 15,000 & $\$ 57$ & $\$ 722$ \\
\hline K-12 Education A & $\$ 4,167$ & 70,700 & $\$ 59$ & $\$ 743$ \\
\hline Office D & $\$ 3,785$ & 83,000 & $\$ 46$ & $\$ 575$ \\
\hline Hospital B & $\$ 121,144$ & 242,470 & $\$ 500$ & $\$ 6,300$ \\
\hline K-12 Education B & $\$ 7,810$ & 83,400 & $\$ 94$ & $\$ 1,181$ \\
\hline K-12 Education C & $\$ 9,180$ & 100,000 & $\$ 92$ & $\$ 1,158$ \\
\hline Medical Office C & $\$ 8,751$ & 46,000 & $\$ 190$ & $\$ 2,399$ \\
\hline Higher Education A & $\$ 9,204$ & 107,000 & $\$ 86$ & $\$ 1,085$ \\
\hline Multipurpose A & $\$ 1,874$ & 16,230 & $\$ 115$ & $\$ 1,456$ \\
\hline Higher Education B & $\$ 8,947$ & 189,500 & $\$ 47$ & $\$ 595$ \\
\hline K-12 Education D & $\$ 604$ & 97,000 & $\$ 6$ & $\$ 78$ \\
\hline K-12 Education E & $\$ 13,878$ & 72,000 & $\$ 193$ & $\$ 2,431$ \\
\hline K-12 Education F & $\$ 5,829$ & 67,800 & $\$ 86$ & $\$ 1,084$ \\
\hline K-12 Education G & $\$ 3,682$ & 42,000 & $\$ 88$ & $\$ 1,106$ \\
\hline Total & $\$ 302,272$ & $1,796,450$ & $\$ 3,573$ & $\$ 45,053$ \\
\hline Average/Building & $\$ 12,595$ & 74,852 & & \\
\hline Overall Average & & & $\$ 168$ & $\$ 2,122$ \\
\hline
\end{tabular}

\subsubsection{Control Measure Impact on Lost Cost Savings}

Lost energy cost savings are shown on a measure-by-measure basis in Table 13. The lost energy cost savings per year were developed (with caveats) as previously described for each measure. These lost savings are shown for the sample, as an average per building, per thousand square foot annually and over a 15 year life. 
Table 13. Lost Energy Cost Savings by Measure

\begin{tabular}{|c|c|c|c|c|}
\hline Measure & $\begin{array}{r}\text { Lost Savings } \\
\text { Total Sample } \\
(\$ / y r) \\
\end{array}$ & $\begin{array}{r}\text { Lost Savings } \\
\text { per Building } \\
(\$ / y r) \\
\end{array}$ & $\begin{array}{r}\text { Lost Savings } \\
(\$ / \text { thousand } \\
\left.\text { ft }^{2}-\mathbf{y r}\right) \\
\end{array}$ & $\begin{array}{r}\text { Present } \\
\text { Value Lost } \\
\text { Savings } \\
(\$ / \text { thousand } \\
\left.\mathbf{f t}^{2}\right) \\
\end{array}$ \\
\hline \multicolumn{5}{|l|}{ HVAC Measures: } \\
\hline TstatDdBnd & $\$ 21,048$ & $\$ 877$ & $\$ 11.72$ & $\$ 148$ \\
\hline EconoInt & $\$ 32,472$ & $\$ 1,353$ & $\$ 18.08$ & $\$ 228$ \\
\hline TstatSetbk & $\$ 60,114$ & $\$ 2,505$ & $\$ 33.46$ & $\$ 422$ \\
\hline SimultHtCl & $\$ 52,875$ & $\$ 2,203$ & $\$ 29.43$ & $\$ 371$ \\
\hline AutoDamp & $\$ 60,891$ & $\$ 2,537$ & $\$ 33.89$ & $\$ 427$ \\
\hline SAT_Reset & $\$ 10,311$ & $\$ 430$ & $\$ 5.74$ & $\$ 72$ \\
\hline ZoneIso & $\$ 178$ & $\$ 7$ & $\$ 0.10$ & $\$ 1$ \\
\hline DCV & $\$ 0$ & $\$ 0$ & $\$ 0.00$ & $\$ 0$ \\
\hline SP_Reset & $\$ 19,328$ & $\$ 805$ & $\$ 10.76$ & $\$ 136$ \\
\hline OptStart & $\$ 31,371$ & $\$ 1,307$ & $\$ 17.46$ & $\$ 220$ \\
\hline \multicolumn{5}{|l|}{ Lighting Measures: } \\
\hline OccSenLtg & $\$ 2,554$ & $\$ 106$ & $\$ 1.42$ & $\$ 18$ \\
\hline DayLtgCtl & $\$ 2,831$ & $\$ 118$ & $\$ 1.58$ & $\$ 20$ \\
\hline ExtLtgCtl & $\$ 805$ & $\$ 34$ & $\$ 0.45$ & $\$ 6$ \\
\hline IntLtgCtl & $\$ 7,495$ & $\$ 312$ & $\$ 4.17$ & $\$ 53$ \\
\hline \multicolumn{5}{|l|}{ Summary: } \\
\hline HVAC Measures & $\$ 288,588$ & $\$ 12,025$ & $\$ 161$ & $\$ 2,026$ \\
\hline Lighting Measures & $\$ 13,684$ & $\$ 570$ & $\$ 8$ & $\$ 96$ \\
\hline Overall & $\$ 302,272$ & $\$ 12,595$ & $\$ 168$ & $\$ 2,122$ \\
\hline
\end{tabular}

\subsubsection{The Value of Commissioning}

There is a question of whether there is value to commissioning control measures in new buildings. Prior studies have shown such benefits (Mills et al. 2004); however, a specific analysis of code-required controls has not been undertaken. While the caveats previously discussed do apply, and the results cannot be considered a definitive or exact projection of avoided lost savings due to commissioning, it is thought beneficial to look at the difference between commissioned and noncommissioned buildings.

As described in Section 5.3.2, commissioning was found to have a significant impact on the configured perspective scores of only four measures (occupancy sensor lighting, thermostat setback, automatic outside air dampers, and optimum start). Commissioning may have a significant impact on other measures as well, but the sample size was not adequate to detect that. For the four impacted measures, the analysis in Appendix $\mathrm{C}$ indicates that commissioning may provide an energy savings benefit overall of about \$103 per thousand square feet per year or \$1,301 on a life-cycle cost basis over 15 years. A larger sample of buildings is likely to find larger potential savings per square foot for commissioning than was found here. 


\subsection{Conclusions and Recommendations}

One of the more positive findings to come out of this project is the high average score (9.5) for the capability of the 14 high-impact control measures to achieve the code described operations. In fact, out of the 247 observations, 85\% had perfect scores for compliance capability. Configuration scores were not as high with an average score of 7.6 and only 50\% with perfectly compliant configuration. The fact that compliance scores are significantly lower shows that the ability exists to achieve additional savings in these buildings with low added cost. It also indicates that incentive programs or regulations that are based on energy outcomes could be a catalyst for improved controls configuration.

Some valuable conclusions about the impact of commissioning can be made from this study. Five of the measures had at least marginally significant impacts from commissioning and all impacts resulted in energy savings. The low significance was likely due to the small number of buildings that were not commissioned. More definitive results could be obtained from a larger sample, with more noncommissioned measures.

Most commissioning agents clearly indicated that verifying code compliance was not a part of their scope of work. Instead, their focus was on ensuring the owner's design intent was met and systems were installed and operating in accordance with design and construction documents. This indicates that if not specified correctly in design documents, code requirements may not be commissioned. The field survey found that only $46 \%$ of observations found fully compliant designs specified, and for $18 \%$ of the cases, the measure was not included in the design at all. Both model energy codes require that design documents fully demonstrate compliance with the code, but it is evident from both the commissioning agent interviews and the field study that this is not always the case. Efforts including training of designers and an emphasis on design compliance by building officials could lead to significant improvement.

As there is a high correlation between design compliance and proper configuration of controls, a focused effort on training designers on how to specify code-required controls is warranted. The upcoming ASHRAE Guideline 36-High Performance Sequences of Operation for HVAC Systems-may be of use in reducing this problem, especially if it gets elevated to a standard and is adopted by multiple controls manufacturers. Also, building officials should focus on verification of controls requirements in the design documents, as this activity is much less time intensive than field verification and is expected to improve the desired configuration compliance.

Another interesting finding is that some control measures are very often capable of meeting coderequired operations even though not specified in the design and not fully configured to meet the code. This indicates that manufacturers and controls contractors are including code-required capabilities as standard practice. As noted previously, most construction contracts include a clause that the building must meet code, therefore educating controls contractors about code requirements could be beneficial, even if designers do not always include specific configuration requirements.

The biggest failures in matching the actual field configuration of controls to code requirements were thermostat setback, optimum start, thermostat deadband, economizer controls, and daylighting. Zone isolation controls may also be an issue, but there was only one applicable instance in the study. If the potential lost savings cost impact is considered instead of lowest configuration scores, the most impactful measures are thermostat setback, automatic outside dampers, and simultaneous heating and cooling 
control. It is important to note that most of these seriously non-compliant observations occurred because of HVAC systems that were allowed to operate continuously when serving spaces that are completely unoccupied for extended periods. This appears to be a regular operational occurrence among commercial buildings, and was noted to occur in over $20 \%$ of the subject building population sample. These types of schedule adjustments are easy for building operators to make, and outreach efforts such as training or required tune-up of existing buildings could have a substantial impact on reducing this energy waste.

The potential recovered lost energy cost savings through better compliance with the 14 impactful control measures is substantial at $\$ 168$ /thousand $\mathrm{ft}^{2}$-yr, or $\$ 2,122 /$ thousand $\mathrm{ft}^{2}$ present value (discounted over the 15 year life of the control measures). To put that in perspective, nationally weighted average energy use for new buildings constructed to Standard 90.1-2010 (similar to the base code under which most of these buildings were constructed) is approximately $\$ 1,420 /$ thousand $\mathrm{ft}^{2}$-yr, (Zhang et al. 2014). This indicates that approximately $12 \%$ of total building energy cost could be saved through better compliance with these measures.

Finally, as in a previous compliance study done by PNNL, recruiting utilizing a cold call approach proved to be ineffective (Rosenberg et al. 2016). In fact, for this study, out of 24 buildings recruited only one was through the cold call approach. While the warm call approach (based on known industry contacts) was much more successful, it is not replicable in larger, more diverse studies and could tend to skew results. As suggested in Rosenberg et al. (2016) an alternative approach would be to have buildings selected for inclusion in a compliance study as part of the code enforcement process, so that the independent compliance activity carried the authority of the jurisdiction and the building information would be received directly from the code officials. 


\subsection{References}

Architecture 2030. 2011. “The 2030 Challenge.” 2030 Inc. Santa Fe, NM. http://www.architecture2030.org/2030_challenge/the_2030_challenge.

ASHRAE. 2008. ASHRAE Vision 2020: Providing tools by 2020 that enable the building community to produce market-viable NZEBs by 2030. American Society of Heating, Refrigerating and AirConditioning Engineers, Atlanta, GA.

https://www.ashrae.org/File\%20Library/docLib/Public/20080226_ashraevision2020.pdf

ASHRAE. 2013. Energy Standard for Buildings Except Low-Rise Residential Buildings. ANSI/ASHRAE/IES Standard 90.1-2013, American Society of Heating, Refrigerating, and AirConditioning Engineers, Atlanta, GA.

CEC. 2003. Advanced Variable Air Volume System Design Guide. California Energy Commission, Sacramento, CA. http://www.energy.ca.gov/2003publications/CEC-500-2003-082/CEC-500-2003-082-A11.PDF

CEC. 2015. Building Energy Efficiency Standards for Residential and Non-Residential Buildings. California Energy Commission, Sacramento, CA. http://www.energy.ca.gov/2012publications/CEC-4002012-004/CEC-400-2012-004-CMF-REV2.pdf

DOE. 2015. About Building Energy Codes. U.S. Department of Energy, Washington, D.C. https://www.energycodes.gov/about.

DOE. 2016. Building Energy Codes Program, Status of State Energy Code Adoption. Washington, D.C. http://www.energycodes.gov/adoption/states.

ICC. 2015. International Energy Conservation Code. International Code Council. 2015. Washington D.C.

Fernandez, N., S. Katipamula, W. Wang, Y. Huang, G. Liu. Energy Savings Modeling of Standard Commercial Building Retuning Measures: Large Office Buildings. PNNL-21569. Richland, Washington: Pacific Northwest National Laboratory.

Lavappa P and JD Kneifel. 2015. Energy Price Indices and Discount Factors for Life-Cycle Cost Analysis-2015: Annual Supplement to NIST Handbook 135, 2015. NISTIR 85-3273-30, National Institute of Standards and Technology, Washington, D.C. Available at http://dx.doi.org/10.6028/NIST.IR.85-3273$\underline{30 .}$.

Mann, H. B. and D.R. Whitney. 1947. On a Test of Whether one of Two Random Variables is Stochastically Larger than the Other. Ann. Math. Statist. 18 (1947), no. 1, 50-60. doi:10.1214/aoms/1177730491. http://projecteuclid.org/euclid.aoms/1177730491.

Mills E, H Friedman, T Powell, N Bourassa, D Claridge, T Haasl, and MA Piette. 2004. The CostEffectiveness of Commercial-Buildings Commissioning: A Meta-Analysis of Energy and Non-Energy Impacts in Existing Buildings and New Construction in the United States. Report 56637, Lawrence Berkeley National Laboratory, Berkeley, CA. http://evanmills.lbl.gov/pubs/pdf/cx-costs-benefits.pdf 
Rosenberg, M., R. Hart, R. Athalye, J.Zhang, W. Wang, B. Liu, 2016. An Approach to Assessing Potential Energy Cost Savings from Increased Energy Code Compliance in Commercial Buildings. PNNL-24979. Richland, Washington: Pacific Northwest National Laboratory. http://www.pnnl.gov/main/publications/external/technical_reports/PNNL-24979.pdf

Siegel, S. and N. J. Castellan. 1988. Non Parametric Statistics for the Behavioural Sciences. MacGraw Hill International., New York. pp 213-214.

Thornton B, M Rosenberg, E Richman, W Wang, Y Xie, J Zhang, H Cho, V Mendon, R Athalye, and B Liu. 2011. Achieving the 30\% Goal: Energy and Cost Savings Analysis of ASHRAE Standard 90.1-2010. PNNL-20405, Pacific Northwest National Laboratory, Richland, WA.

https://www.energycodes.gov/sites/default/files/documents/BECP_Energy_Cost_Savings_STD2010_Ma y2011_v00.pdf

USGBC. 2014. LEED V4 for Building Design and Construction. United States Green Building Council. Washington, D.C.

http://www.usgbc.org/sites/default/files/LEED\%20v4\%20BDC_10\%2001\%2014_current.pdf.

Washington State. 2014. 2012 Washington State Energy Code. International Code Council, Washington, D.C. https://fortress.wa.gov/ga/apps/SBCC/File.ashx?cid=2892 


\section{Appendix A}

Controls Requirements in ASHRAE Standard 90.1-2013 and the 2015 IECC 


\section{Appendix A}

\section{Controls Requirements in ASHRAE Standard 90.1-2013 and the 2015 IECC}

Table of controls requirements

\begin{tabular}{|c|c|c|c|c|c|c|c|}
\hline & Measure & $\begin{array}{l}\text { Std } \\
90.1- \\
2013 \\
\text { Section } \\
\text { Number }\end{array}$ & $\begin{array}{l}\text { Std } 90.1-2013 \\
\text { Section Title }\end{array}$ & Std 90.1-2013 Requirement & $\begin{array}{l}2015 \text { IECC } \\
\text { Section } \\
\text { Number }\end{array}$ & $\begin{array}{l}2015 \text { IECC } \\
\text { Section Title }\end{array}$ & 2015 IECC Requirement \\
\hline 1 & $\begin{array}{l}\text { Air curtain } \\
\text { controls for } \\
\text { velocity and } \\
\text { maximum } \\
\text { velocity }\end{array}$ & NA & NA & NA & C402.5.7 & Vestibules & $\begin{array}{l}\text { Exception } 6 \text {. Doors that have an air curtain with a } \\
\text { velocity of not less than } 6.56 \text { feet per second ( } 2 \\
\mathrm{~m} / \mathrm{s} \text { ) at the floor that have been tested in } \\
\text { accordance with ANSI/AMCA } 220 \text { and installed in } \\
\text { accordance with the manufacturer's instructions. } \\
\text { Manual or automatic controls shall be provided that } \\
\text { will operate the air curtain with the opening and } \\
\text { closing of the door. Air curtains and their controls } \\
\text { shall comply with Section C408.2.3. }\end{array}$ \\
\hline 2 & $\begin{array}{c}\text { Automatic } \\
\text { outdoor air } \\
\text { damper } \\
\text { controls }\end{array}$ & 6.4.3.4.1 & $\begin{array}{l}\text { Stair and Shaft } \\
\text { Vents }\end{array}$ & $\begin{array}{l}\text { Stair and elevator shaft vents shall be } \\
\text { equipped with motorized dampers that are } \\
\text { capable of being automatically closed during } \\
\text { normal building operation and are interlocked } \\
\text { to open as required by fire and smoke } \\
\text { detection systems. }\end{array}$ & C403.2.4.3 & $\begin{array}{l}\text { Shutoff } \\
\text { dampers. }\end{array}$ & See C403.2.4.3 below - combined. \\
\hline
\end{tabular}




\begin{tabular}{|c|c|c|c|c|c|c|c|}
\hline & Measure & $\begin{array}{l}\text { Std } \\
90.1- \\
2013 \\
\text { Section } \\
\text { Number }\end{array}$ & $\begin{array}{l}\text { Std 90.1-2013 } \\
\text { Section Title }\end{array}$ & Std 90.1-2013 Requirement & $\begin{array}{l}2015 \text { IECC } \\
\text { Section } \\
\text { Number }\end{array}$ & $\begin{array}{l}2015 \text { IECC } \\
\text { Section Title }\end{array}$ & 2015 IECC Requirement \\
\hline & $\begin{array}{l}\text { Automatic } \\
\text { outdoor air } \\
\text { damper } \\
\text { controls }\end{array}$ & 6.4 .3 .4 .2 & $\begin{array}{l}\text { Shutoff Damper } \\
\text { Controls }\end{array}$ & $\begin{array}{l}\text { All outdoor air intake and exhaust systems } \\
\text { shall be equipped with motorized dampers } \\
\text { that will automatically shut when the systems } \\
\text { or spaces served are not in use. Ventilation } \\
\text { outdoor air and exhaust/relief dampers shall } \\
\text { be capable of automatically shutting off } \\
\text { during preoccupancy building warm-up, } \\
\text { cooldown, and setback, except when } \\
\text { ventilation reduces energy costs or when } \\
\text { ventilation must be supplied to meet code } \\
\text { requirements. Exceptions: } 1 \text {. Back draft } \\
\text { gravity (non-motorized) dampers are } \\
\text { acceptable for exhaust and relief in buildings } \\
\text { less than three stories in height and for } \\
\text { ventilation air intakes and exhaust and relief } \\
\text { dampers in buildings of any height located in } \\
\text { Climate zones } 1,2 \text {, and } 3 \text {. Back draft dampers } \\
\text { for ventilation air intakes must be protected } \\
\text { from direct exposure to wind. } 2 \text {. Back draft } \\
\text { gravity (non-motorized) dampers are } \\
\text { acceptable in systems with a design outdoor } \\
\text { air intake or exhaust capacity of } 300 \text { cfm or } \\
\text { less. } 3 \text {. Dampers are not required in } \\
\text { ventilation or exhaust systems serving } \\
\text { unconditioned spaces. } 4 \text {. Dampers are not } \\
\text { required in exhaust systems serving Type } 1 \\
\text { kitchen exhaust hoods. }\end{array}$ & C403.2.4.3 & $\begin{array}{l}\text { Shutoff } \\
\text { dampers. }\end{array}$ & $\begin{array}{l}\text { Outdoor air intake and exhaust openings and } \\
\text { stairway and shaft vents shall be provided with } \\
\text { Class I motorized dampers. The dampers shall have } \\
\text { an air leakage rate not greater than } 4 \mathrm{cfm} / \mathrm{ft} 2 \text { ( } 20.3 \\
\mathrm{~L} / \mathrm{s} \cdot \mathrm{m}^{2} \text { ) of damper surface area at } 1.0 \text { inch water } \\
\text { gauge ( } 249 \mathrm{~Pa} \text { ) and shall be labeled by an approved } \\
\text { agency when tested in accordance with AMCA } 500 \mathrm{D} \\
\text { for such purpose. Outdoor air intake and exhaust } \\
\text { dampers shall be installed with automatic controls } \\
\text { configured to close when the systems or spaces } \\
\text { served are not in use or during unoccupied period } \\
\text { warm-up and setback operation, unless the systems } \\
\text { served require outdoor or exhaust air in accordance } \\
\text { with the International Mechanical Code or the } \\
\text { dampers are opened to provide intentional } \\
\text { economizer cooling. Stairway and shaft vent } \\
\text { dampers shall be installed with automatic controls } \\
\text { configured to open upon the activation of any fire } \\
\text { alarm initiating device of the building's fire alarm } \\
\text { system or the interruption of power to the damper. } \\
\text { Exception: Gravity (non-motorized) dampers shall } \\
\text { be permitted to be used as follows: } 1 . \text { In buildings } \\
\text { less than three stories in height above grade plane. } \\
2 \text {. In buildings of any height located in Climate } \\
\text { zones } 1,2 \text { or } 3.3 \text {. Where the design exhaust } \\
\text { capacity is not greater than } 300 \mathrm{cfm}(142 \mathrm{~L} / \mathrm{s}) \text {. } \\
\text { Gravity (non-motorized) dampers shall have an air } \\
\text { leakage rate not greater than } 20 \mathrm{cfm} / \mathrm{ft} 2(101.6 \mathrm{~L} / \mathrm{s} \text {. } \\
\left.\mathrm{m}^{2} \text { ) where not less than } 24 \text { inches ( } 610 \mathrm{~mm}\right) \text { in } \\
\left.\text { either dimension and } 40 \mathrm{cfm} / \mathrm{ft} 2 \text { ( } 203.2 \mathrm{~L} / \mathrm{s} \cdot \mathrm{m} \mathrm{m}^{2}\right) \\
\text { where less than } 24 \text { inches ( } 610 \mathrm{~mm}) \text { in either } \\
\text { dimension. The rate of air leakage shall be } \\
\text { determined at } 1.0 \text { inch water gauge }(249 \mathrm{~Pa}) \text { when } \\
\text { tested in accordance with AMCA } 500 \mathrm{D} \text { for such } \\
\text { purpose. The dampers shall be labeled by an } \\
\text { approved agency. }\end{array}$ \\
\hline 3 & $\begin{array}{l}\text { Boiler } \\
\text { temperature } \\
\text { reset }\end{array}$ & & & NA & C403.2.5 & $\begin{array}{l}\text { Hot water } \\
\text { boiler outdoor } \\
\text { temperature } \\
\text { setback } \\
\text { control. }\end{array}$ & $\begin{array}{l}\text { Hot water boilers that supply heat to the building } \\
\text { through one- or two-pipe heating systems shall } \\
\text { have an outdoor setback control that lowers the } \\
\text { boiler water temperature based on the outdoor } \\
\text { temperature. }\end{array}$ \\
\hline
\end{tabular}




\begin{tabular}{|c|c|c|c|c|c|c|c|}
\hline \multicolumn{2}{|c|}{ Measure } & $\begin{array}{l}\text { Std } \\
90.1- \\
2013 \\
\text { Section } \\
\text { Number }\end{array}$ & $\begin{array}{l}\text { Std 90.1-2013 } \\
\text { Section Title }\end{array}$ & Std 90.1-2013 Requirement & $\begin{array}{l}2015 \text { IECC } \\
\text { Section } \\
\text { Number }\end{array}$ & $\begin{array}{l}2015 \text { IECC } \\
\text { Section Title }\end{array}$ & 2015 IECC Requirement \\
\hline 4 & $\begin{array}{l}\text { Control of } \\
\text { dynamic } \\
\text { glazing }\end{array}$ & NA & NA & NA & C402.4.3.3 & $\begin{array}{l}\text { Dynamic } \\
\text { glazing }\end{array}$ & $\begin{array}{l}\text { Where dynamic glazing is intended to satisfy the } \\
\text { solar heat gain coefficient (SHGC) and VT } \\
\text { requirements of Table C402.4, the ratio of the } \\
\text { higher to lower labeled SHGC shall be greater than } \\
\text { or equal to } 2.4 \text {, and the dynamic glazing shall be } \\
\text { automatically controlled to modulate the amount of } \\
\text { solar gain into the space in multiple steps. Dynamic } \\
\text { glazing shall be considered separately from other } \\
\text { fenestration, and area-weighted averaging with } \\
\text { other fenestration that is not dynamic glazing shall } \\
\text { not be permitted. Exception: Dynamic glazing is not } \\
\text { required to comply with this section where both the } \\
\text { lower and higher labeled SHGC already comply with } \\
\text { the requirements of Table C402.3. }\end{array}$ \\
\hline & $\begin{array}{l}\text { Daylighting } \\
\text { controls } \\
\text { implemented } \\
\text { correctly } \\
\text { when } \\
\text { required } \\
\end{array}$ & NA & NA & NA & C402.4 & $\begin{array}{l}\text { Fenestration } \\
\text { (Prescriptive) }\end{array}$ & $\begin{array}{l}\text { Fenestration shall comply with Sections C402.4 } \\
\text { through C402.4.4 and Table C402.4. Daylight- } \\
\text { responsive controls shall comply with this section } \\
\text { and Section C405.2.3.1. }\end{array}$ \\
\hline & $\begin{array}{c}\text { Daylighting } \\
\text { controls } \\
\text { implemented } \\
\text { correctly } \\
\text { when } \\
\text { required } \\
\end{array}$ & 5.5.4.2.3 & $\begin{array}{l}\text { Minimum } \\
\text { Skylight } \\
\text { Fenestration } \\
\text { Area }\end{array}$ & $\begin{array}{l}\text { General lighting in the daylight area shall be } \\
\text { controlled as described in Section 9.4.1.1(f). }\end{array}$ & C402.4.2.1 & $\begin{array}{l}\text { Lighting } \\
\text { controls in } \\
\text { daylight zones } \\
\text { under skylights }\end{array}$ & $\begin{array}{l}\text { Daylight-responsive controls complying with Section } \\
\text { C405.2.3.1 shall be provided to control all electric } \\
\text { lights with daylight zones under skylights. }\end{array}$ \\
\hline 5 & $\begin{array}{l}\text { Daylighting } \\
\text { controls } \\
\text { implemented } \\
\text { correctly } \\
\text { when } \\
\text { required }\end{array}$ & NA & NA & NA & C402.4.1.1 & $\begin{array}{l}\text { Increased } \\
\text { vertical } \\
\text { fenestration } \\
\text { area with } \\
\text { daylight- } \\
\text { responsive } \\
\text { controls. }\end{array}$ & $\begin{array}{l}\text { In Climate zones } 1 \text { through } 6 \text {, not more than } 40 \\
\text { percent of the gross above grade wall area shall be } \\
\text { permitted to be vertical fenestration, provided all of } \\
\text { the following requirements are met: } 1 \text {. In buildings } \\
\text { not greater than two stories above grade, not less } \\
\text { than } 50 \text { percent of the net floor area is within a } \\
\text { daylight zone. } 2 \text {. In buildings three or more stories } \\
\text { above grade, not less than } 25 \text { percent of the net } \\
\text { floor area is within a daylight zone. 3. Daylight- } \\
\text { responsive controls complying with Section } \\
\text { C405.2.3.1 are installed in daylight zones. } 4 \text {. Visible } \\
\text { transmittance of vertical fenestration is not less } \\
\text { than } 1.1 \text { times SHGC. Exception: Fenestration that is } \\
\text { outside the scope of NFRC } 200 \text { is not required to } \\
\text { comply with Item } 4 \text {. }\end{array}$ \\
\hline
\end{tabular}




\begin{tabular}{|c|c|c|c|c|c|c|}
\hline Measure & $\begin{array}{l}\text { Std } \\
90.1- \\
2013 \\
\text { Section } \\
\text { Number }\end{array}$ & $\begin{array}{l}\text { Std 90.1-2013 } \\
\text { Section Title }\end{array}$ & Std 90.1-2013 Requirement & $\begin{array}{l}2015 \text { IECC } \\
\text { Section } \\
\text { Number }\end{array}$ & $\begin{array}{l}2015 \text { IECC } \\
\text { Section Title }\end{array}$ & 2015 IECC Requirement \\
\hline $\begin{array}{l}\text { Daylighting } \\
\text { controls } \\
\text { implemented } \\
\text { correctly } \\
\text { when } \\
\text { required } \\
\end{array}$ & NA & NA & NA & C402.4.1.2 & $\begin{array}{l}\text { Increased } \\
\text { skylight area } \\
\text { with daylight- } \\
\text { responsive } \\
\text { controls. }\end{array}$ & $\begin{array}{l}\text { The skylight area shall be permitted to be not more } \\
\text { than } 5 \text { percent of the roof area provided daylight- } \\
\text { responsive controls complying with Section } \\
\text { C405.2.3.1 are installed in daylight zones under } \\
\text { skylights. }\end{array}$ \\
\hline $\begin{array}{l}\text { Daylighting } \\
\text { controls } \\
\text { implemented } \\
\text { correctly } \\
\text { when } \\
\text { required }\end{array}$ & 5.5.4.2.3 & $\begin{array}{l}\text { Minimum } \\
\text { Skylight } \\
\text { Fenestration } \\
\text { Area }\end{array}$ & $\begin{array}{l}\text { Exception } 5 . \text { Enclosed spaces where the total } \\
\text { area minus the primary and secondary } \\
\text { sidelighted area(s) is less than } 2500 \mathrm{ft} 2 \text { and } \\
\text { where the lighting is controlled according to } \\
\text { sidelighting requirements described in Section } \\
\text { 9.4.1.1(e). }\end{array}$ & C402.4.2 & $\begin{array}{l}\text { Minimum } \\
\text { skylight } \\
\text { fenestration } \\
\text { area }\end{array}$ & $\begin{array}{l}\text { 5. Spaces where the total area minus the area of } \\
\text { daylight zones adjacent to vertical fenestration is } \\
\text { less than } 2,500 \text { square feet }\left(232 \mathrm{~m}^{2}\right) \text {, and where the } \\
\text { lighting is controlled according to Section C405.2.5. }\end{array}$ \\
\hline $\begin{array}{l}\text { Daylighting } \\
\text { controls } \\
\text { implemented } \\
\text { correctly } \\
\text { when } \\
\text { required }\end{array}$ & 5.5 .4 .4 .2 & $\begin{array}{l}\text { SHGC of } \\
\text { Skylights }\end{array}$ & $\begin{array}{l}\text { Exception } 1 \text { (c) They have all general lighting } \\
\text { in the daylight area under skylights controlled } \\
\text { by multilevel photocontrols in accordance } \\
\text { with Section 9.4.1.1(f). }\end{array}$ & C402.4.3.1 & $\begin{array}{l}\text { Increased } \\
\text { skylight SHGC }\end{array}$ & $\begin{array}{l}\text { In Climate zones } 1 \text { through } 6 \text {, skylights shall be } \\
\text { permitted a maximum SHGC of } 0.60 \text { where located } \\
\text { above daylight zones provided with daylight- } \\
\text { responsive controls. }\end{array}$ \\
\hline $\begin{array}{l}\text { Daylighting } \\
\text { controls } \\
\text { implemented } \\
\text { correctly } \\
\text { when } \\
\text { required }\end{array}$ & NA & NA & NA & C402.4.3.2 & $\begin{array}{l}\text { Increased } \\
\text { skylight U- } \\
\text { factor }\end{array}$ & $\begin{array}{l}\text { Where skylights are installed above daylight zones } \\
\text { provided with daylight-responsive controls, a } \\
\text { maximum U-factor of } 0.9 \text { shall be permitted in } \\
\text { Climate zones } 1 \text { through } 3 \text { and a maximum U-factor } \\
\text { of } 0.75 \text { shall be permitted in Climate zones } 4 \\
\text { through } 8 \text {. }\end{array}$ \\
\hline
\end{tabular}




\begin{tabular}{|c|c|c|c|c|c|c|}
\hline Measure & $\begin{array}{l}\text { Std } \\
90.1- \\
2013 \\
\text { Section } \\
\text { Number }\end{array}$ & $\begin{array}{l}\text { Std } 90.1-2013 \\
\text { Section Title }\end{array}$ & Std 90.1-2013 Requirement & $\begin{array}{l}2015 \text { IECC } \\
\text { Section } \\
\text { Number }\end{array}$ & $\begin{array}{l}2015 \text { IECC } \\
\text { Section Title }\end{array}$ & 2015 IECC Requirement \\
\hline $\begin{array}{l}\text { Daylighting } \\
\text { controls } \\
\text { implemented } \\
\text { correctly } \\
\text { when } \\
\text { required }\end{array}$ & & $\begin{array}{l}\text { Interior Lighting } \\
\text { Controls }\end{array}$ & $\begin{array}{l}\text { e. Automatic daylight-responsive controls for } \\
\text { sidelighting: In any space where the } \\
\text { combined input power of all general lighting } \\
\text { completely or partially within the primary } \\
\text { sidelighted areas is } 150 \text { W or greater, the } \\
\text { general lighting in the primary sidelighted } \\
\text { areas shall be controlled by photocontrols. In } \\
\text { any space where the combined input power } \\
\text { of all general lighting completely or partially } \\
\text { within the primary and secondary sidelighted } \\
\text { areas is } 300 \text { W or greater, the general lighting } \\
\text { in the primary sidelighted areas and } \\
\text { secondary sidelighted areas shall be } \\
\text { controlled by photocontrols. The control } \\
\text { system shall have the following } \\
\text { characteristics: } 1 \text {. The calibration adjustments } \\
\text { shall be readily accessible. } 2 \text {. At minimum, } \\
\text { general lighting in the secondary sidelighted } \\
\text { area shall be controlled independently of the } \\
\text { general lighting in the primary sidelighted } \\
\text { area. } 3 \text {. The photocontrol shall reduce electric } \\
\text { lighting in response to available daylight using } \\
\text { continuous dimming or with at least one } \\
\text { control point between } 50 \% \text { and } 70 \% \text { of design } \\
\text { lighting power, a second control point } \\
\text { between } 20 \% \text { and } 40 \% \text { of design lighting } \\
\text { power or the lowest dimming level the } \\
\text { technology allows, and a third control point } \\
\text { that turns off all the controlled lighting. } \\
\text { Exceptions: The following areas are exempted } \\
\text { from Section } 9.4 .1 .1(\text { e): } 1 \text {. Primary sidelighted } \\
\text { areas where the top of any existing adjacent } \\
\text { structure is twice as high above the windows } \\
\text { as its distance away from the windows } 2 \text {. } \\
\text { Sidelighted areas where the total glazing area } \\
\text { is less than } 20 \text { ft2 } 3 \text {. Retail spaces. }\end{array}$ & C405.2.3 & $\begin{array}{l}\text { Daylight- } \\
\text { responsive } \\
\text { controls. }\end{array}$ & $\begin{array}{l}\text { Daylight-responsive controls complying with Section } \\
\text { C405.2.3.1 shall be provided to control the electric } \\
\text { lights within daylight zones in the following spaces: } \\
\text { 1. Spaces with a total of more than } 150 \text { watts of } \\
\text { general lighting within sidelight daylight zones } \\
\text { complying with Section C405.2.3.2. General lighting } \\
\text { does not include lighting that is required to have } \\
\text { specific application control in accordance with } \\
\text { Section C405.2.4. } 2 \text {. Spaces with a total of more } \\
\text { than } 150 \text { watts of general lighting within toplight } \\
\text { daylight zones complying with Section C405.2.3.3. } \\
\text { Exceptions: Daylight-responsive controls are not } \\
\text { required for the following: } 1 \text {. Spaces in health care } \\
\text { facilities where patient care is directly provided. } 2 \text {. } \\
\text { Dwelling units and sleeping units. 3. Lighting that is } \\
\text { required to have specific application control in } \\
\text { accordance with Section C405.2.4. } 4 \text {. Sidelight } \\
\text { daylight zones on the first floor above grade in } \\
\text { Group A-2 and Group M occupancies. }\end{array}$ \\
\hline
\end{tabular}




\begin{tabular}{|c|c|c|c|c|c|c|}
\hline Measure & $\begin{array}{l}\text { Std } \\
90.1- \\
2013 \\
\text { Section } \\
\text { Number }\end{array}$ & $\begin{array}{l}\text { Std 90.1-2013 } \\
\text { Section Title }\end{array}$ & Std 90.1-2013 Requirement & $\begin{array}{l}2015 \text { IECC } \\
\text { Section } \\
\text { Number }\end{array}$ & $\begin{array}{l}2015 \text { IECC } \\
\text { Section Title }\end{array}$ & 2015 IECC Requirement \\
\hline $\begin{array}{l}\text { Daylighting } \\
\text { controls } \\
\text { implemented } \\
\text { correctly } \\
\text { when } \\
\text { required }\end{array}$ & NA & NA & NA & C405.2.3.1 & $\begin{array}{l}\text { Daylight- } \\
\text { responsive } \\
\text { control } \\
\text { function. }\end{array}$ & $\begin{array}{l}\text { Where required, daylight-responsive controls shall } \\
\text { be provided within each space for control of lights } \\
\text { in that space and shall comply with all of the } \\
\text { following: } 1 \text {. Lights in toplight daylight zones in } \\
\text { accordance with Section C405.2.3.3 shall be } \\
\text { controlled independently of lights in sidelight } \\
\text { daylight zones in accordance with Section } \\
\text { C405.2.3.2. 2. Daylight-responsive controls within } \\
\text { each space shall be configured so that they can be } \\
\text { calibrated from within that space by authorized } \\
\text { personnel. } 3 \text {. Calibration mechanisms shall be } \\
\text { readily accessible. } 4 \text {. Where located in offices, } \\
\text { classrooms, laboratories and library reading rooms, } \\
\text { daylight-responsive controls shall dim lights } \\
\text { continuously from full light output to } 15 \text { percent of } \\
\text { full light output or lower. } 5 \text {. Daylight-responsive } \\
\text { controls shall be capable of a complete shutoff of all } \\
\text { controlled lights. } 6 \text {. Lights in sidelight daylight zones } \\
\text { in accordance with Section C405.2.3.2 facing } \\
\text { different cardinal orientations [i.e., within } 45 \\
\text { degrees (0.79 rad) of due north, east, south, west] } \\
\text { shall be controlled independently of each other. } \\
\text { Exception: Up to } 150 \text { watts of lighting in each space } \\
\text { is permitted to be controlled together with lighting } \\
\text { in a daylight zone facing a different cardinal } \\
\text { orientation. }\end{array}$ \\
\hline
\end{tabular}




\begin{tabular}{|c|c|c|c|c|c|c|}
\hline Measure & $\begin{array}{l}\text { Std } \\
90.1- \\
2013 \\
\text { Section } \\
\text { Number }\end{array}$ & $\begin{array}{l}\text { Std } 90.1-2013 \\
\text { Section Title }\end{array}$ & Std 90.1-2013 Requirement & $\begin{array}{l}2015 \text { IECC } \\
\text { Section } \\
\text { Number }\end{array}$ & $\begin{array}{l}2015 \text { IECC } \\
\text { Section Title }\end{array}$ & 2015 IECC Requirement \\
\hline $\begin{array}{l}\text { Daylighting } \\
\text { controls } \\
\text { implemented } \\
\text { correctly } \\
\text { when } \\
\text { required }\end{array}$ & $9.4 .1 .1 \mathrm{f}$ & $\begin{array}{l}\text { Interior Lighting } \\
\text { Controls }\end{array}$ & $\begin{array}{l}\text { f. Automatic daylight-responsive controls for } \\
\text { toplighting:In any space where the combined } \\
\text { input power for all general lighting completely } \\
\text { or partially within daylight areas under } \\
\text { skylights and daylight areas under roof } \\
\text { monitors is } 150 \text { W or greater, general lighting } \\
\text { in the daylight area shall be controlled by } \\
\text { photocontrols having the following } \\
\text { characteristics: } 1 \text {. The calibration adjustments } \\
\text { shall be readily accessible. } 2 \text {. The } \\
\text { photocontrol shall reduce electric lighting in } \\
\text { response to available daylight using } \\
\text { continuous dimming or with at least one } \\
\text { control point that is between } 50 \% \text { and } 70 \% \text { of } \\
\text { design lighting power, a second control point } \\
\text { between } 20 \% \text { and } 40 \% \text { of design lighting } \\
\text { power or the lowest dimming level the } \\
\text { technology allows, and a third control point } \\
\text { that turns off all the controlled lighting. } 3 . \\
\text { General lighting in overlapping toplighted and } \\
\text { sidelighted daylight areas shall be controlled } \\
\text { together with general lighting in the daylight } \\
\text { area under skylights or daylight areas under } \\
\text { roof monitors. Exceptions: The following } \\
\text { areas are exempted from Section } 9.4 .1 .1(f): 1 . \\
\text { Daylight areas under skylights where it is } \\
\text { documented that existing adjacent structures } \\
\text { or natural objects block direct sunlight for } \\
\text { more than } 1500 \text { daytime hours per year } \\
\text { between } 8 \text { a.m. and } 4 \text { p.m. } 2 \text {. Daylight areas } \\
\text { where the skylight visual transmittance is less } \\
\text { than } 0.43 . \text { In each space within buildings in } \\
\text { climate zone } 8 \text { where the input power of the } \\
\text { general lighting within daylight areas is less } \\
\text { than } 200 \text { W. }\end{array}$ & C405.2.3 & $\begin{array}{l}\text { Daylight- } \\
\text { responsive } \\
\text { controls. }\end{array}$ & $\begin{array}{l}\text { Daylight-responsive controls complying with Section } \\
\text { C405.2.3.1 shall be provided to control the electric } \\
\text { lights within daylight zones in the following spaces: } \\
\text { 1. Spaces with a total of more than } 150 \text { watts of } \\
\text { general lighting within sidelight daylight zones } \\
\text { complying with Section C405.2.3.2. General lighting } \\
\text { does not include lighting that is required to have } \\
\text { specific application control in accordance with } \\
\text { Section C405.2.4. } 2 \text {. Spaces with a total of more } \\
\text { than } 150 \text { watts of general lighting within toplight } \\
\text { daylight zones complying with Section C405.2.3.3. } \\
\text { Exceptions: Daylight-responsive controls are not } \\
\text { required for the following: } 1 \text {. Spaces in health care } \\
\text { facilities where patient care is directly provided. } 2 \text {. } \\
\text { Dwelling units and sleeping units. 3. Lighting that is } \\
\text { required to have specific application control in } \\
\text { accordance with Section C405.2.4. } 4 \text {. Sidelight } \\
\text { daylight zones on the first floor above grade in } \\
\text { Group A-2 and Group M occupancies. }\end{array}$ \\
\hline
\end{tabular}




\begin{tabular}{|c|c|c|c|c|c|c|c|}
\hline & Measure & $\begin{array}{l}\text { Std } \\
90.1- \\
2013 \\
\text { Section } \\
\text { Number }\end{array}$ & $\begin{array}{l}\text { Std 90.1-2013 } \\
\text { Section Title }\end{array}$ & Std 90.1-2013 Requirement & $\begin{array}{l}2015 \text { IECC } \\
\text { Section } \\
\text { Number }\end{array}$ & $\begin{array}{l}2015 \text { IECC } \\
\text { Section Title }\end{array}$ & 2015 IECC Requirement \\
\hline & $\begin{array}{l}\text { Daylighting } \\
\text { controls } \\
\text { implemented } \\
\text { correctly } \\
\text { when } \\
\text { required }\end{array}$ & & & NA & C405.2.3.1 & $\begin{array}{l}\text { Daylight- } \\
\text { responsive } \\
\text { control } \\
\text { function. }\end{array}$ & $\begin{array}{l}\text { Where required, daylight-responsive controls shall } \\
\text { be provided within each space for control of lights } \\
\text { in that space and shall comply with all of the } \\
\text { following: } 1 \text {. Lights in toplight daylight zones in } \\
\text { accordance with Section C405.2.3.3 shall be } \\
\text { controlled independently of lights in sidelight } \\
\text { daylight zones in accordance with Section } \\
\text { C405.2.3.2. 2. Daylight-responsive controls within } \\
\text { each space shall be configured so that they can be } \\
\text { calibrated from within that space by authorized } \\
\text { personnel. 3. Calibration mechanisms shall be } \\
\text { readily accessible. } 4 \text {. Where located in offices, } \\
\text { classrooms, laboratories and library reading rooms, } \\
\text { daylight-responsive controls shall dim lights } \\
\text { continuously from full light output to } 15 \text { percent of } \\
\text { full light output or lower. } 5 \text {. Daylight-responsive } \\
\text { controls shall be capable of a complete shutoff of all } \\
\text { controlled lights. 6. Lights in sidelight daylight zones } \\
\text { in accordance with Section C405.2.3.2 facing } \\
\text { different cardinal orientations [i.e., within } 45 \\
\text { degrees (0.79 rad) of due north, east, south, west] } \\
\text { shall be controlled independently of each other. } \\
\text { Exception: Up to } 150 \text { watts of lighting in each space } \\
\text { is permitted to be controlled together with lighting } \\
\text { in a daylight zone facing a different cardinal } \\
\text { orientation. }\end{array}$ \\
\hline 6 & $\begin{array}{l}\text { Demand } \\
\text { controlled } \\
\text { ventilation }\end{array}$ & $6.3 .2 q$ & Criteria & $\begin{array}{l}\text { q. The system shall comply with the demand } \\
\text { control ventilation requirements in Section } \\
\text { 6.4.3.8. }\end{array}$ & NA & NA & NA \\
\hline
\end{tabular}




\begin{tabular}{|c|c|c|c|c|c|c|c|}
\hline \multicolumn{2}{|c|}{ Measure } & $\begin{array}{l}\text { Std } \\
90.1- \\
2013 \\
\text { Section } \\
\text { Number } \\
\end{array}$ & $\begin{array}{l}\text { Std 90.1-2013 } \\
\text { Section Title }\end{array}$ & Std 90.1-2013 Requirement & $\begin{array}{l}2015 \text { IECC } \\
\text { Section } \\
\text { Number }\end{array}$ & $\begin{array}{l}2015 \text { IECC } \\
\text { Section Title }\end{array}$ & 2015 IECC Requirement \\
\hline & $\begin{array}{l}\text { Demand } \\
\text { controlled } \\
\text { ventilation }\end{array}$ & 6.4 .3 .8 & $\begin{array}{l}\text { Ventilation } \\
\text { Controls for } \\
\text { High-Occupancy } \\
\text { Areas }\end{array}$ & $\begin{array}{l}\text { Demand control ventilation (DCV) is required } \\
\text { for spaces larger than } 500 \mathrm{ft} 2 \text { and with a } \\
\text { design occupancy for ventilation of greater } \\
\text { than }{ }^{3} 25 \text { people per } 1000 \mathrm{ft} 2 \text { of floor area and } \\
\text { served by systems with one or more of the } \\
\text { following: a. Air-side economizer b. Automatic } \\
\text { modulating control of outdoor air damper c. } \\
\text { Design outdoor airflow greater than } 3000 \\
\text { cfm. Exceptions: } 1 \text {. Systems with the exhaust } \\
\text { air energy recovery complying with Section } \\
6.5 .6 .1 .2 \text {. Multiple-zone systems without } \\
\text { direct digital control (DDC) of individual zones } \\
\text { communicating with a central control panel } 3 . \\
\text { Systems with a design outdoor airflow less } \\
\text { than } 750 \text { cfm } 4 \text {. Spaces where }>75 \% \text { of the } \\
\text { space design outdoor airflow is required for } \\
\text { makeup air that is exhausted from the space } \\
\text { or transfer air that is required for makeup air } \\
\text { that is exhausted from other space(s) } 5 \text {. } \\
\text { Spaces with one of the following occupancy } \\
\text { categories as defined in ASHRAE Standard } \\
62.1 \text { correctional cells, daycare sickrooms, } \\
\text { science labs, barbers, beauty and nail salons, } \\
\text { and bowling alley seating. }\end{array}$ & C403.2.6.1 & $\begin{array}{l}\text { Demand } \\
\text { controlled } \\
\text { ventilation }\end{array}$ & $\begin{array}{l}\text { DCV shall be provided for spaces larger than } 500 \\
\text { square feet }\left(46.5 \mathrm{~m}^{2}\right) \text { and with an average occupant } \\
\text { load of } 25 \text { people per } 1,000 \text { square feet }\left(93 \mathrm{~m}^{2}\right) \text { of } \\
\text { floor area (as established in Table } 403.3 \text { of the } \\
\text { International Mechanical Code) and served by } \\
\text { systems with one or more of the following: } 1 \text {. An } \\
\text { air-side economizer. } 2 \text {. Automatic modulating } \\
\text { control of the outdoor air damper. } 3 \text {. A design } \\
\text { outdoor airflow greater than } 3,000 \mathrm{cfm}(1416 \mathrm{~L} / \mathrm{s}) \text {. } \\
\text { Exception: Demand control ventilation is not } \\
\text { required for systems and spaces as follows: } 1 \text {. } \\
\text { Systems with energy recovery complying with } \\
\text { Section C403.2.7. } 2 \text {. Multiple-zone systems without } \\
\text { DDC of individual zones communicating with a } \\
\text { central control panel. } 3 \text {. Systems with a design } \\
\text { outdoor airflow less than } 1,200 \text { cfm ( } 566 \mathrm{~L} / \mathrm{s}) .4 \text {. } \\
\text { Spaces where the supply airflow rate minus any } \\
\text { makeup or outgoing transfer air requirement is less } \\
\text { than } 1,200 \mathrm{cfm}(566 \mathrm{~L} / \mathrm{s}) .5 \text {. Ventilation provided for } \\
\text { process loads only. }\end{array}$ \\
\hline \multirow[b]{2}{*}{7} & $\begin{array}{l}\text { Economizer } \\
\text { integration } \\
\text { and high limit } \\
\text { controls }\end{array}$ & 6.5.1.1.2 & Control Signal & $\begin{array}{l}\text { Economizer dampers shall be capable of being } \\
\text { sequenced with the mechanical cooling } \\
\text { equipment and shall not be controlled by only } \\
\text { mixed-air temperature. Exception: The use of } \\
\text { mixed-air temperature limit control shall be } \\
\text { permitted for systems controlled from space } \\
\text { temperature (such as single-zone systems). }\end{array}$ & C403.3.3.2 & Control signal. & $\begin{array}{l}\text { Economizer dampers shall be capable of being } \\
\text { sequenced with the mechanical cooling equipment } \\
\text { and shall not be controlled by only mixed-air } \\
\text { temperature. Exception: The use of mixed-air } \\
\text { temperature limit control shall be permitted for } \\
\text { systems controlled from space temperature (such } \\
\text { as single-zone systems). }\end{array}$ \\
\hline & $\begin{array}{l}\text { Economizer } \\
\text { integration } \\
\text { and high limit } \\
\text { controls }\end{array}$ & 6.5.1.1.3 & $\begin{array}{l}\text { High-Limit } \\
\text { Shutoff }\end{array}$ & $\begin{array}{l}\text { All air economizers shall be capable of } \\
\text { automatically reducing outdoor air intake to } \\
\text { the design minimum outdoor air quantity } \\
\text { when outdoor air intake will no longer reduce } \\
\text { cooling energy usage. High-limit shutoff } \\
\text { control types and associated setpoints for } \\
\text { specific climate zones shall be chosen from } \\
\text { Table 6.5.1.1.3. }\end{array}$ & C403.3.3.3 & $\begin{array}{l}\text { High-limit } \\
\text { shutoff. }\end{array}$ & $\begin{array}{l}\text { Air economizers shall be capable of automatically } \\
\text { reducing outdoor air intake to the design minimum } \\
\text { outdoor air quantity when outdoor air intake will no } \\
\text { longer reduce cooling energy usage. High-limit } \\
\text { shutoff control types for specific climates shall be } \\
\text { chosen from Table C403.3.3.3. High-limit shutoff } \\
\text { control settings for these control types shall be } \\
\text { those specified in Table C403.3.3.3. }\end{array}$ \\
\hline
\end{tabular}




\begin{tabular}{|c|c|c|c|c|c|c|}
\hline Measure & $\begin{array}{l}\text { Std } \\
90.1- \\
2013 \\
\text { Section } \\
\text { Number }\end{array}$ & $\begin{array}{l}\text { Std 90.1-2013 } \\
\text { Section Title }\end{array}$ & Std 90.1-2013 Requirement & $\begin{array}{l}2015 \text { IECC } \\
\text { Section } \\
\text { Number }\end{array}$ & $\begin{array}{l}2015 \text { IECC } \\
\text { Section Title }\end{array}$ & 2015 IECC Requirement \\
\hline $\begin{array}{l}\text { Economizer } \\
\text { integration } \\
\text { and high limit } \\
\text { controls }\end{array}$ & 6.5 .1 .3 & $\begin{array}{l}\text { Integrated } \\
\text { Economizer } \\
\text { Control }\end{array}$ & $\begin{array}{l}\text { Economizer systems shall be integrated with } \\
\text { the mechanical cooling system and be } \\
\text { capable of providing partial cooling even } \\
\text { when additional mechanical cooling is } \\
\text { required to meet the remainder of the cooling } \\
\text { load. Controls shall not false load the } \\
\text { mechanical cooling systems by limiting or } \\
\text { disabling the economizer or by any other } \\
\text { means, such as hot gas bypass, except at the } \\
\text { lowest stage of mechanical cooling. Units that } \\
\text { include an air economizer shall comply with } \\
\text { the following: a. Unit controls shall have the } \\
\text { mechanical cooling capacity control } \\
\text { interlocked with the air economizer controls } \\
\text { such that the outdoor air damper is at the } \\
100 \% \text { open position when mechanical cooling } \\
\text { is on, and the outdoor air damper does not } \\
\text { begin to close to prevent coil freezing due to } \\
\text { minimum compressor run time until the } \\
\text { leaving air temperature is less than } 45^{\circ} \mathrm{F} \text {. b. } \\
\text { DX units that control the capacity of the } \\
\text { mechanical cooling directly based on } \\
\text { occupied space temperature shall have a } \\
\text { minimum of two stages of mechanical cooling } \\
\text { capacity per the following effective dates: } \\
{ }^{3} 75,000 \text { Btu/h Rated Capacity-Effective } \\
1 / 1 / 2014^{3} 65,000 \text { Btu/h Rated Capacity- } \\
\text { Effective } 1 / 1 / 2016 \text {. }\end{array}$ & C403.3.1 & $\begin{array}{l}\text { Integrated } \\
\text { economizer } \\
\text { control. }\end{array}$ & $\begin{array}{l}\text { Economizer systems shall be integrated with the } \\
\text { mechanical cooling system and be capable of } \\
\text { providing partial cooling even where additional } \\
\text { mechanical cooling is required to provide the } \\
\text { remainder of the cooling load. Controls shall not be } \\
\text { capable of creating a false load in the mechanical } \\
\text { cooling systems by limiting or disabling the } \\
\text { economizer or any other means, such as hot gas } \\
\text { bypass, except at the lowest stage of mechanical } \\
\text { cooling. Units that include an air economizer shall } \\
\text { comply with the following: } 1 \text {. Unit controls shall } \\
\text { have the mechanical cooling capacity control } \\
\text { interlocked with the air economizer controls such } \\
\text { that the outdoor air damper is at the } 100-\text { percent } \\
\text { open position when mechanical cooling is on and } \\
\text { the outdoor air damper does not begin to close to } \\
\text { prevent coil freezing due to minimum compressor } \\
\text { run time until the leaving air temperature is less } \\
\text { than } 45^{\circ} \mathrm{F}\left(7^{\circ} \mathrm{C}\right) \text {. } 2 \text {. Direct expansion (DX) units that } \\
\text { control } 75,000 \text { Btu/h ( } 22 \mathrm{~kW} \text { ) or greater of rated } \\
\text { capacity of the capacity of the mechanical cooling } \\
\text { directly based on occupied space temperature shall } \\
\text { have not fewer than two stages of mechanical } \\
\text { cooling capacity } 3 \text {. Other DX units, including those } \\
\text { that control space temperature by modulating the } \\
\text { airflow to the space, shall be in accordance with } \\
\text { Table } \mathrm{C} 403.3 .1 \text {. }\end{array}$ \\
\hline $\begin{array}{l}\text { Economizer } \\
\text { integration } \\
\text { and high limit } \\
\text { controls }\end{array}$ & NA & NA & NA & C403.3.1 & $\begin{array}{l}\text { Integrated } \\
\text { economizer } \\
\text { control }\end{array}$ & $\begin{array}{l}\text { Economizer systems shall be integrated with the } \\
\text { mechanical cooling system and be capable of } \\
\text { providing partial cooling even where additional } \\
\text { mechanical cooling is required to provide the } \\
\text { remainder of the cooling load. Controls shall not be } \\
\text { capable of creating a false load in the mechanical } \\
\text { cooling systems by limiting or disabling the } \\
\text { economizer or any other means, such as hot gas } \\
\text { bypass, except at the lowest stage of mechanical } \\
\text { cooling. }\end{array}$ \\
\hline
\end{tabular}




\begin{tabular}{|c|c|c|c|c|c|c|c|}
\hline & Measure & $\begin{array}{l}\text { Std } \\
90.1- \\
2013 \\
\text { Section } \\
\text { Number }\end{array}$ & $\begin{array}{l}\text { Std } 90.1-2013 \\
\text { Section Title }\end{array}$ & Std 90.1-2013 Requirement & $\begin{array}{l}2015 \text { IECC } \\
\text { Section } \\
\text { Number }\end{array}$ & $\begin{array}{l}2015 \text { IECC } \\
\text { Section Title }\end{array}$ & 2015 IECC Requirement \\
\hline 8 & $\begin{array}{l}\text { Economizer } \\
\text { heating } \\
\text { impact } \\
\text { limitation }\end{array}$ & 6.5 .1 .5 & $\begin{array}{l}\text { Economizer } \\
\text { Heating System } \\
\text { Impact }\end{array}$ & $\begin{array}{l}\text { HVAC system design and economizer controls } \\
\text { shall be such that economizer operation does } \\
\text { not increase the building heating energy use } \\
\text { during normal operation. Exceptions: } \\
\text { Economizers on VAV systems that cause zone- } \\
\text { level heating to increase due to a reduction in } \\
\text { supply air temperature. }\end{array}$ & C403.3.2 & $\begin{array}{l}\text { Economizer } \\
\text { heating system } \\
\text { impact. }\end{array}$ & $\begin{array}{l}\text { HVAC system design and economizer controls shall } \\
\text { be such that economizer operation does not } \\
\text { increase building heating energy use during normal } \\
\text { operation. Exception: Economizers on variable air } \\
\text { volume (VAV) systems that cause zone level heating } \\
\text { to increase due to a reduction in supply air } \\
\text { temperature. }\end{array}$ \\
\hline 9 & $\begin{array}{l}\text { Elevator } \\
\text { standby } \\
\text { lighting and } \\
\text { ventilation } \\
\text { controls }\end{array}$ & $\begin{array}{l}\text { 10.4.3.1, } \\
10.4 .3 .2, \\
\text { and } \\
10.4 .3 .3\end{array}$ & $\begin{array}{l}\text { Lighting and } \\
\text { Ventilation } \\
\text { Power Limitation } \\
\text { and } \\
\text { Standby Mode }\end{array}$ & $\begin{array}{l}\text { For the luminaires in each elevator cab, not } \\
\text { including signals and displays, the sum of the } \\
\text { lumens divided by the sum of the watts (as } \\
\text { described in Section 9.1.4) shall be no less } \\
\text { than } 35 \mathrm{Im} / \mathrm{W} \text {. } \\
\text { Cab ventilation fans for elevators without air } \\
\text { conditioning shall not consume over } 0.33 \\
\text { W/cfm at maximum speed. } \\
\text { When stopped and unoccupied with doors } \\
\text { closed for over } 15 \text { minutes, cab interior } \\
\text { lighting and ventilation shall be de-energized } \\
\text { until required for operation. }\end{array}$ & C405.9.1 & Elevator cabs. & $\begin{array}{l}\text { For the luminaires in each elevator cab, not } \\
\text { including signals and displays, the sum of the } \\
\text { lumens divided by the sum of the watts shall be not } \\
\text { less than } 35 \text { lumens per watt. Ventilation fans in } \\
\text { elevators that do not have their own air- } \\
\text { conditioning system shall not consume more than } \\
0.33 \text { watts/cfm at the maximum rated speed of the } \\
\text { fan. Controls shall be provided that will de-energize } \\
\text { ventilation fans and lighting systems when the } \\
\text { elevator is stopped, unoccupied and with its doors } \\
\text { closed for over } 15 \text { minutes. }\end{array}$ \\
\hline
\end{tabular}




\begin{tabular}{|c|c|c|c|c|c|c|c|}
\hline & Measure & $\begin{array}{l}\text { Std } \\
90.1- \\
2013 \\
\text { Section } \\
\text { Number }\end{array}$ & $\begin{array}{l}\text { Std 90.1-2013 } \\
\text { Section Title }\end{array}$ & Std 90.1-2013 Requirement & $\begin{array}{l}2015 \text { IECC } \\
\text { Section } \\
\text { Number }\end{array}$ & $\begin{array}{l}2015 \text { IECC } \\
\text { Section Title }\end{array}$ & 2015 IECC Requirement \\
\hline 10 & $\begin{array}{c}\text { Energy } \\
\text { recovery } \\
\text { economizer } \\
\text { bypass }\end{array}$ & 6.5 .6 .1 & $\begin{array}{l}\text { Exhaust Air } \\
\text { Energy Recovery }\end{array}$ & $\begin{array}{l}\text { Each fan system shall have an energy } \\
\text { recovery system when the system's supply } \\
\text { airflow rate exceeds the value listed in Tables } \\
6.5 .6 .1-1 \text { and } 6.5 .6 .1-2 \text {, based on the climate } \\
\text { zone and percentage of outdoor airflow rate } \\
\text { at design conditions. Table } 6.5 .6 .1-1 \text { shall be } \\
\text { used for all ventilation systems that operate } \\
\text { less than } 8000 \text { hours per year, and Table } \\
6.5 .6 .1-2 \text { shall be used for all ventilation } \\
\text { systems that operate } 8000 \text { or more hours per } \\
\text { year. Energy recovery systems required by } \\
\text { this section shall have at least } 50 \% \text { energy } \\
\text { recovery effectiveness. Fifty percent energy } \\
\text { recovery effectiveness shall mean a change in } \\
\text { the enthalpy of the outdoor air supply equal } \\
\text { to } 50 \% \text { of the difference between the outdoor } \\
\text { air and return air enthalpies at design } \\
\text { conditions. Provision shall be made to bypass } \\
\text { or control the energy recovery system to } \\
\text { permit air economizer operation as required } \\
\text { by Section } 6.5 .1 .1 \text {. Exceptions: } 1 . \text { Laboratory } \\
\text { systems meeting Section } 6.5 .7 .2 \text {. Systems } \\
\text { serving spaces that are not cooled and that } \\
\text { are heated to less than } 60^{\circ} \text { F. } 3 \text {. Systems } \\
\text { exhausting toxic, flammable, paint, or } \\
\text { corrosive fumes or dust } 4 . \text { Commercial } \\
\text { kitchen hoods used for collecting and } \\
\text { removing grease vapors and smoke } 5 \text {. Where } \\
\text { more than } 60 \% \text { of the outdoor air heating } \\
\text { energy is provided from site-recovered or site } \\
\text { solar energy } 6 . \text { Heating energy recovery in } \\
\text { Climate zones } 1 \text { and } 2 \text {. }\end{array}$ & C403.2.7 & $\begin{array}{l}\text { Energy } \\
\text { recovery } \\
\text { ventilation } \\
\text { systems. }\end{array}$ & $\begin{array}{l}\text { Where the supply airflow rate of a fan system } \\
\text { exceeds the values specified in Tables C403.2.7(1) } \\
\text { and C403.2.7(2), the system shall include an energy } \\
\text { recovery system. The energy recovery system shall } \\
\text { have the capability to provide a change in the } \\
\text { enthalpy of the outdoor air supply of not less than } \\
50 \text { percent of the difference between the outdoor } \\
\text { air and return air enthalpies, at design conditions. } \\
\text { Where an air economizer is required, the energy } \\
\text { recovery system shall include a bypass or controls } \\
\text { which permit operation of the economizer as } \\
\text { required by Section C403.3. Exception: An energy } \\
\text { recovery ventilation system shall not be required in } \\
\text { any of the following conditions: } 1 \text {. Where energy } \\
\text { recovery systems are prohibited by the } \\
\text { International Mechanical Code. } 2 \text {. Laboratory fume } \\
\text { hood systems that include at least one of the } \\
\text { following features: } 2.1 \text {. Variable-air-volume hood } \\
\text { exhaust and room supply systems capable of } \\
\text { reducing exhaust and makeup air volume to } 50 \\
\text { percent or less of design values. } 2.2 \text {. Direct makeup } \\
\text { (auxiliary) air supply equal to at least } 75 \text { percent of } \\
\text { the exhaust rate, heated not warmer than } 2^{\circ} \mathrm{F} \\
\left(1.1^{\circ} \mathrm{C}\right) \text { above room setpoint, cooled to not cooler } \\
\text { than } 3^{\circ} \mathrm{F}\left(1.7^{\circ} \mathrm{C} \text { ) below room setpoint, no }\right. \\
\text { humidification added, and no simultaneous heating } \\
\text { and cooling used for dehumidification control. } 3 \text {. } \\
\text { Systems serving spaces that are heated to less than } \\
60^{\circ} \mathrm{F}\left(15.5^{\circ} \mathrm{C}\right) \text { and are not cooled. } 4 \text {. Where more } \\
\text { than } 60 \text { percent of the outdoor heating energy is } \\
\text { provided from site-recovered or site solar energy. } 5 . \\
\text { Heating energy recovery in Climate zones } 1 \text { and } 2 . \\
6 . \text { Cooling energy recovery in Climate zones } 3 \mathrm{C}, 4 \mathrm{C} \text {, } \\
5 \mathrm{~B}, 5 \mathrm{C}, 6 \mathrm{~B}, 7 \text { and } 8.7 \text {. Systems requiring } \\
\text { dehumidification that employ energy recovery in } \\
\text { series with the cooling coil. } 8 \text {. Where the largest } \\
\text { source of air exhausted at a single location at the } \\
\text { building exterior is less than } 75 \text { percent of the } \\
\text { design outdoor air flow rate. } 9 . \text { Systems expected to } \\
\text { operate less than } 20 \text { hours per week at the outdoor } \\
\text { air percentage covered by Table C403.2.7(1). } 10 . \\
\text { Systems exhausting toxic, flammable, paint or }\end{array}$ \\
\hline
\end{tabular}




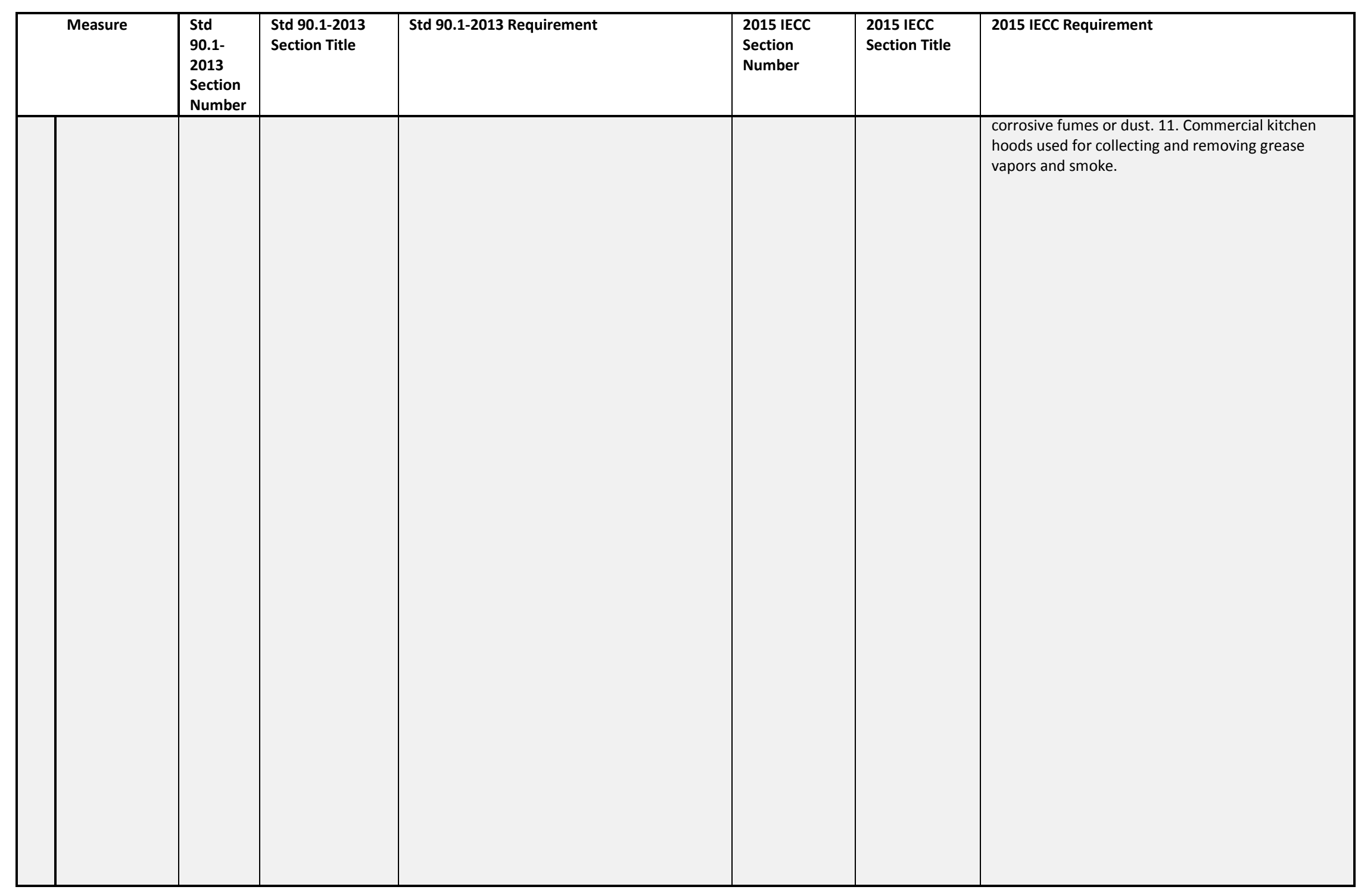




\begin{tabular}{|c|c|c|c|c|c|c|c|}
\hline & Measure & $\begin{array}{l}\text { Std } \\
90.1- \\
2013 \\
\text { Section } \\
\text { Number }\end{array}$ & $\begin{array}{l}\text { Std } 90.1-2013 \\
\text { Section Title }\end{array}$ & Std 90.1-2013 Requirement & $\begin{array}{l}2015 \text { IECC } \\
\text { Section } \\
\text { Number }\end{array}$ & $\begin{array}{l}2015 \text { IECC } \\
\text { Section Title }\end{array}$ & 2015 IECC Requirement \\
\hline 11 & $\begin{array}{l}\text { Escalator and } \\
\text { moving } \\
\text { walkway } \\
\text { demand } \\
\text { control }\end{array}$ & 10.4 .4 & $\begin{array}{l}\text { Escalators and } \\
\text { Moving Walks }\end{array}$ & $\begin{array}{l}\text { Escalators and moving walks shall } \\
\text { automatically slow to the minimum permitted } \\
\text { speed in accordance with ASME A17.1/CSA } \\
\text { B44 or applicable local code when not } \\
\text { conveying passengers. }\end{array}$ & C405.9.2 & $\begin{array}{l}\text { Escalators and } \\
\text { moving walks. }\end{array}$ & $\begin{array}{l}\text { Escalators and moving walks shall comply with } \\
\text { ASME A17.1/CSA B44 and shall have automatic } \\
\text { controls configured to reduce speed to the } \\
\text { minimum permitted speed in accordance with } \\
\text { ASME A17.1/CSA B44 or applicable local code when } \\
\text { not conveying passengers. }\end{array}$ \\
\hline 12 & $\begin{array}{l}\text { Exterior } \\
\text { lighting } \\
\text { controls }\end{array}$ & 9.4 .1 .4 & $\begin{array}{l}\text { Exterior Lighting } \\
\text { Controls }\end{array}$ & $\begin{array}{l}\text { Lighting for exterior applications not } \\
\text { exempted in Section } 9.1 \text { shall meet the } \\
\text { following requirements: a. Lighting shall be } \\
\text { controlled by a device that automatically } \\
\text { turns off the lighting when sufficient daylight } \\
\text { is available. b. All building façade and } \\
\text { landscape lighting shall be automatically shut } \\
\text { off between midnight or business closing, } \\
\text { whichever is later, and } 6 \text { a.m. or business } \\
\text { opening, whichever comes first, or between } \\
\text { times established by the authority having } \\
\text { jurisdiction. c. Lighting not specified in Section } \\
9.4 .1 .4(\text { b) and lighting for signage shall be } \\
\text { controlled by a device that automatically } \\
\text { reduces the connected lighting power by at } \\
\text { least } 30 \% \text { for at least one of the following } \\
\text { conditions: } 1 \text {. From } 12 \text { midnight or within one } \\
\text { (1) hour of the end of business operations, } \\
\text { whichever is later, until } 6 \text { a.m. or business } \\
\text { opening, whichever is earlier } 2 \text {. During any } \\
\text { period when no activity has been detected for } \\
\text { a time of no longer than } 15 \text { minutes All time } \\
\text { switches shall be capable of retaining } \\
\text { programming and the time setting during loss } \\
\text { of power for a period of at least ten hours. } \\
\text { Exceptions: } 1 \text {. Lighting for covered vehicle } \\
\text { entrances or exits from buildings or parking } \\
\text { structures where required for safety, security, } \\
\text { or eye adaptation } 2 \text {. Lighting that is integral to } \\
\text { signage and installed in the signage by the } \\
\text { manufacturer. }\end{array}$ & C405.2.5 & $\begin{array}{l}\text { Exterior } \\
\text { lighting } \\
\text { controls. }\end{array}$ & $\begin{array}{l}\text { Lighting for exterior applications other than } \\
\text { emergency lighting that is intended to be } \\
\text { automatically off during building operation, lighting } \\
\text { specifically required to meet health and life safety } \\
\text { requirements or decorative gas lighting systems } \\
\text { shall: } 1 \text {. Be provided with a control that } \\
\text { automatically turns off the lighting as a function of } \\
\text { available daylight. } 2 \text {. Where lighting the building } \\
\text { façade or landscape, the lighting shall have controls } \\
\text { that automatically shut off the lighting as a function } \\
\text { of dawn/dusk and a set opening and closing time. } 3 \text {. } \\
\text { Where not covered in Item } 2 \text {, the lighting shall have } \\
\text { controls configured to automatically reduce the } \\
\text { connected lighting power by not less than } 30 \\
\text { percent from not later than midnight to } 6 \text { a.m., } \\
\text { from one hour after business closing to one hour } \\
\text { before business opening or during any period when } \\
\text { activity has not been detected for a time of longer } \\
\text { than } 15 \text { minutes. All time switches shall be able to } \\
\text { retain programming and the time setting during loss } \\
\text { of power for a period of at least } 10 \text { hours. } \\
\text { Exception: Lighting for covered vehicle entrances or } \\
\text { exits from buildings or parking structures where } \\
\text { required for safety, security or eye adaptation. }\end{array}$ \\
\hline
\end{tabular}




\begin{tabular}{|c|c|c|c|c|c|c|c|}
\hline & Measure & $\begin{array}{l}\text { Std } \\
90.1- \\
2013 \\
\text { Section } \\
\text { Number }\end{array}$ & $\begin{array}{l}\text { Std 90.1-2013 } \\
\text { Section Title }\end{array}$ & Std 90.1-2013 Requirement & $\begin{array}{l}2015 \text { IECC } \\
\text { Section } \\
\text { Number }\end{array}$ & $\begin{array}{l}2015 \text { IECC } \\
\text { Section Title }\end{array}$ & 2015 IECC Requirement \\
\hline & $\begin{array}{c}\text { Fan static } \\
\text { pressure reset } \\
\text { controls }\end{array}$ & 6.5 .3 .2 .2 & $\begin{array}{l}\text { VAV Static } \\
\text { Pressure Sensor } \\
\text { Location }\end{array}$ & $\begin{array}{l}\text { Static pressure sensors used to control VAV } \\
\text { fans shall be located such that the controller } \\
\text { setpoint is no greater than } 1.2 \text { in. wc If this } \\
\text { results in the sensor being located } \\
\text { downstream of major duct splits, sensors shall } \\
\text { be installed in each major branch to ensure } \\
\text { that static pressure can be maintained in } \\
\text { each. Exception: Systems complying with } \\
\text { Section 6.5.3.2. }\end{array}$ & C403.4.1.2 & $\begin{array}{l}\text { Static pressure } \\
\text { sensor } \\
\text { location. }\end{array}$ & $\begin{array}{l}\text { Static pressure sensors used to control VAV fans } \\
\text { shall be located such that the controller set point is } \\
\text { not greater than } 1.2 \text { inches w.c. ( } 299 \mathrm{~Pa}) \text {. Where } \\
\text { this results in one or more sensors being located } \\
\text { downstream of major duct splits, not less than one } \\
\text { sensor shall be located on each major branch to } \\
\text { ensure that static pressure can be maintained in } \\
\text { each branch. }\end{array}$ \\
\hline 13 & $\begin{array}{c}\text { Fan static } \\
\text { pressure reset } \\
\text { controls }\end{array}$ & 6.5 .3 .2 .3 & $\begin{array}{l}\text { VAV Setpoint } \\
\text { Reset }\end{array}$ & $\begin{array}{l}\text { VAV Setpoint Reset. For systems with DDC } \\
\text { of individual zones reporting to the central } \\
\text { control panel, } \\
\text { static pressure setpoint shall be reset based } \\
\text { on the zone } \\
\text { requiring the most pressure; i.e., the setpoint } \\
\text { is reset lower } \\
\text { until one zone damper is nearly wide open. } \\
\text { Controls shall } \\
\text { provide the following: a. Monitor zone } \\
\text { damper positions or other indicator of need } \\
\text { for static pressure b. Automatically detect } \\
\text { those zones that may be excessively driving } \\
\text { the reset logic and generate an alarm to the } \\
\text { system } \\
\text { operator c. Readily allow operator removal of } \\
\text { zone(s) from the reset } \\
\text { algorithm. }\end{array}$ & C403.4.1.3 & $\begin{array}{l}\text { Set points for } \\
\text { DDC. }\end{array}$ & $\begin{array}{l}\text { For systems with DDC of individual reporting to the } \\
\text { central control panel, the static pressure set point } \\
\text { shall be reset based on the zone requiring the most } \\
\text { pressure. In such case, the set point is reset lower } \\
\text { until one zone damper is nearly wide open. The } \\
\text { DDCs shall be capable of monitoring zone damper } \\
\text { positions or shall have an alternative method of } \\
\text { indicating the need for static pressure that is } \\
\text { capable of all of the following: } 1 \text {. Automatically } \\
\text { detecting any zone that excessively drives the reset } \\
\text { logic. } 2 \text {. Generating an alarm to the system } \\
\text { operational location. } 3 \text {. Allowing an operator to } \\
\text { readily remove one or more zones from the reset } \\
\text { algorithm. }\end{array}$ \\
\hline
\end{tabular}




\begin{tabular}{|c|c|c|c|c|c|c|c|}
\hline & Measure & $\begin{array}{l}\text { Std } \\
90.1- \\
2013 \\
\text { Section } \\
\text { Number } \\
\end{array}$ & $\begin{array}{l}\text { Std 90.1-2013 } \\
\text { Section Title }\end{array}$ & Std 90.1-2013 Requirement & $\begin{array}{l}2015 \text { IECC } \\
\text { Section } \\
\text { Number }\end{array}$ & $\begin{array}{l}2015 \text { IECC } \\
\text { Section Title }\end{array}$ & 2015 IECC Requirement \\
\hline 14 & $\begin{array}{c}\text { Fan variable } \\
\text { airflow } \\
\text { control }\end{array}$ & 6.5.3.2.1 & $\begin{array}{l}\text { Fan Airflow } \\
\text { Control }\end{array}$ & $\begin{array}{l}\text { Each cooling system listed in Table } 6.5 .3 .2 .1 \\
\text { shall be designed to vary the indoor fan } \\
\text { airflow as a function of load and shall comply } \\
\text { with the following requirements: a. DX and } \\
\text { chilled-water cooling units that control the } \\
\text { capacity of the mechanical cooling directly } \\
\text { based on space temperature shall have a } \\
\text { minimum of two stages of fan control. Low or } \\
\text { minimum speed shall not exceed } 66 \% \text { of full } \\
\text { speed. At low or minimum speed, the fan } \\
\text { system shall draw no more than } 40 \% \text { of the } \\
\text { fan power at full fan speed. Low or minimum } \\
\text { speed shall be used during periods of low } \\
\text { cooling load and ventilation only operation. b. } \\
\text { All other units, including DX cooling units and } \\
\text { chilled-water units that control the space } \\
\text { temperature by modulating the airflow to the } \\
\text { space, shall have modulating fan control. } \\
\text { Minimum speed shall not exceed } 50 \% \text { of full } \\
\text { speed. At minimum speed, the fan system } \\
\text { shall draw no more than } 30 \% \text { of the power at } \\
\text { full fan speed. Low or minimum speed shall } \\
\text { be used during periods of low cooling load } \\
\text { and ventilation only operation. c. Units that } \\
\text { include an air-side economizer to meet the } \\
\text { requirements of Section } 6.5 .1 \text { shall have a } \\
\text { minimum of two speeds of fan control during } \\
\text { economizer operation. Exceptions: } 1 \text {. } \\
\text { Modulating fan control is not required for } \\
\text { chilled-water and evaporative cooling units } \\
\text { with <1 hp fan motors if the units are not } \\
\text { used to provide ventilation air and the indoor } \\
\text { fan cycles with the load. } 2 . \text { If the volume of } \\
\text { outdoor air required to meet the ventilation } \\
\text { requirements of Standard } 62.1 \text { at low speed } \\
\text { exceeds the air that would be delivered at the } \\
\text { speed defined in Section } 6.5 .3 .2 .1(a) \text { or } \\
6.5 .3 .2 .1(\text { (b) then the minimum speed shall be } \\
\text { selected to provide the required ventilation } \\
\text { air. }\end{array}$ & C403.4.1.1 & $\begin{array}{l}\text { Fan airflow } \\
\text { control. }\end{array}$ & $\begin{array}{l}\text { Each cooling system listed in Table C403.4.1.1 shall } \\
\text { be designed to vary the indoor fan airflow as a } \\
\text { function of load and shall comply with the following } \\
\text { requirements: } 1 \text {. Direct expansion (DX) and chilled- } \\
\text { water cooling units that control the capacity of the } \\
\text { mechanical cooling directly based on space } \\
\text { temperature shall have not fewer than two stages } \\
\text { of fan control. Low or minimum speed shall not be } \\
\text { greater than } 66 \text { percent of full speed. At low or } \\
\text { minimum speed, the fan system shall draw not } \\
\text { more than } 40 \text { percent of the fan power at full fan } \\
\text { speed. Low or minimum speed shall be used during } \\
\text { periods of low cooling load and ventilation only } \\
\text { operation. } 2 \text {. Other units including DX cooling units } \\
\text { and chilled-water units that control the space } \\
\text { temperature by modulating the airflow to the space } \\
\text { shall have modulating fan control. Minimum speed } \\
\text { shall be not greater than } 50 \text { percent of full speed. At } \\
\text { minimum speed the fan system shall draw not more } \\
\text { than } 30 \text { percent of the power at full fan speed. Low } \\
\text { or minimum speed shall be used during periods of } \\
\text { low cooling load and ventilation only operation. } 3 \text {. } \\
\text { Units that include an air-side economizer in } \\
\text { accordance with Section C403.3 shall have not } \\
\text { fewer than two speeds of fan control during } \\
\text { economizer operation Exceptions: } 1 \text {. Modulating } \\
\text { fan control is not required for chilled water and } \\
\text { evaporative cooling units with fan motors of less } \\
\text { than } 1 \text { hp ( } 0.746 \text { kW) where the units are not used } \\
\text { to provide ventilation air and the indoor fan cycles } \\
\text { with the load. } 2 \text {. Where the volume of outdoor air } \\
\text { required to comply with the ventilation } \\
\text { requirements of the International Mechanical Code } \\
\text { at low speed exceeds the air that would be } \\
\text { delivered at the speed defined in Section C403.4.1, } \\
\text { the minimum speed shall be selected to provide the } \\
\text { required ventilation air. }\end{array}$ \\
\hline
\end{tabular}




\begin{tabular}{|c|c|c|c|c|c|c|c|}
\hline \multicolumn{2}{|r|}{ Measure } & $\begin{array}{l}\text { Std } \\
90.1- \\
2013 \\
\text { Section } \\
\text { Number } \\
\end{array}$ & $\begin{array}{l}\text { Std } 90.1-2013 \\
\text { Section Title }\end{array}$ & Std 90.1-2013 Requirement & $\begin{array}{l}2015 \text { IECC } \\
\text { Section } \\
\text { Number }\end{array}$ & $\begin{array}{l}2015 \text { IECC } \\
\text { Section Title }\end{array}$ & 2015 IECC Requirement \\
\hline \multirow{3}{*}{15} & $\begin{array}{c}\text { Five degree } \\
\text { thermostat } \\
\text { deadband and } \\
\text { setpoint } \\
\text { overlap } \\
\text { prevention }\end{array}$ & 6.4 .3 .1 .2 & Dead Band & $\begin{array}{l}\text { Where used to control both heating and } \\
\text { cooling, zone thermostatic controls shall be } \\
\text { capable of providing a temperature range or } \\
\text { dead band of at least } 5^{\circ} \mathrm{F} \text { within which the } \\
\text { supply of heating and cooling energy to the } \\
\text { zone is shut off or reduced to a minimum. } \\
\text { Exceptions: } 1 \text {. Thermostats that require } \\
\text { manual changeover between heating and } \\
\text { cooling modes } 2 \text {. Special occupancy or special } \\
\text { applications where wide temperature ranges } \\
\text { are not acceptable (such as retirement } \\
\text { homes, process applications, museums, some } \\
\text { areas of hospitals) and are approved by the } \\
\text { authority having jurisdiction. }\end{array}$ & C403.2.4.1.2 & Deadband & $\begin{array}{l}\text { Where used to control both heating and cooling, } \\
\text { zone thermostatic controls shall be capable of } \\
\text { providing a temperature range or deadband of at } \\
\text { least } 5^{\circ} \mathrm{F}\left(2.8^{\circ} \mathrm{C}\right) \text { within which the supply of heating } \\
\text { and cooling energy to the zone is capable of being } \\
\text { shut off or reduced to a minimum. Exceptions: } 1 . \\
\text { Thermostats requiring manual changeover between } \\
\text { heating and cooling modes. } 2 \text {. Occupancies or } \\
\text { applications requiring precision in indoor } \\
\text { temperature control as approved by the code } \\
\text { official. }\end{array}$ \\
\hline & $\begin{array}{l}\text { Five degree } \\
\text { thermostat } \\
\text { deadband } \\
\text { control and } \\
\text { setpoint } \\
\text { overlap } \\
\text { prevention }\end{array}$ & 6.4 .3 .2 & $\begin{array}{l}\text { Setpoint Overlap } \\
\text { Restriction }\end{array}$ & $\begin{array}{l}\text { Where heating and cooling to a zone are } \\
\text { controlled by separate zone thermostatic } \\
\text { controls located within the zone, means (such } \\
\text { as limit switches; mechanical stops; or, for } \\
\text { DDC systems, software programming) shall be } \\
\text { provided to prevent the heating setpoint from } \\
\text { exceeding the cooling setpoint minus any } \\
\text { applicable proportional band. }\end{array}$ & C403.2.4.1.3 & $\begin{array}{l}\text { Set point } \\
\text { overlap } \\
\text { restriction }\end{array}$ & $\begin{array}{l}\text { Where a zone has a separate heating and a } \\
\text { separate cooling thermostatic control located } \\
\text { within the zone, a limit switch, mechanical stop or } \\
\text { DDC system with software programming shall be } \\
\text { provided with the capability to prevent the heating } \\
\text { set point from exceeding the cooling set point and } \\
\text { to maintain a deadband in accordance with Section } \\
\text { C403.2.4.1.2. }\end{array}$ \\
\hline & $\begin{array}{l}\text { Five degree } \\
\text { thermostat } \\
\text { deadband } \\
\text { control and } \\
\text { setpoint } \\
\text { overlap } \\
\text { prevention }\end{array}$ & $6.3 .2 \mathrm{~g}$ & Criteria & $\begin{array}{l}\text { g. The system shall be controlled by a manual } \\
\text { changeover or dual setpoint thermostat. }\end{array}$ & NA & NA & NA \\
\hline
\end{tabular}




\begin{tabular}{|c|c|c|c|c|c|c|c|}
\hline & Measure & $\begin{array}{l}\text { Std } \\
90.1- \\
2013 \\
\text { Section } \\
\text { Number }\end{array}$ & $\begin{array}{l}\text { Std } 90.1-2013 \\
\text { Section Title }\end{array}$ & Std 90.1-2013 Requirement & $\begin{array}{l}2015 \text { IECC } \\
\text { Section } \\
\text { Number }\end{array}$ & $\begin{array}{l}2015 \text { IECC } \\
\text { Section Title }\end{array}$ & 2015 IECC Requirement \\
\hline 16 & $\begin{array}{l}\text { Fractional HP } \\
\text { fan motor } \\
\text { speed controls }\end{array}$ & 6.5 .3 .5 & $\begin{array}{l}\text { Fractional } \\
\text { Horsepower Fan } \\
\text { Motors }\end{array}$ & $\begin{array}{l}\text { Motors for fans that are } 1 / 12 \mathrm{hp} \text { or greater } \\
\text { and less than } 1 \mathrm{hp} \text { shall be electronically } \\
\text { commutated motors or shall have a minimum } \\
\text { motor efficiency of } 70 \% \text { when rated in } \\
\text { accordance with DOE } 10 \text { CFR } 431 \text {. These } \\
\text { motors shall also have the means to adjust } \\
\text { motor speed for either balancing or remote } \\
\text { control. Beltdriven fans may use sheave } \\
\text { adjustments for airflow balancing in lieu of a } \\
\text { varying motor speed. Exceptions: } 1 \text {. Motors in } \\
\text { the airstream within fan coils and terminal } \\
\text { units that operate only when providing } \\
\text { heating to the space served } 2 \text {. Motors } \\
\text { installed in space-conditioning equipment } \\
\text { certified under Section } 6.4 .13 \text {. Motors } \\
\text { covered by Table } 10.8-4 \text { or } 10.8-5 \text {. }\end{array}$ & C403.4.4.4 & $\begin{array}{l}\text { Fractional hp } \\
\text { fan motors. }\end{array}$ & $\begin{array}{l}\text { Motors for fans that are not less than } 1 / 12 \mathrm{hp} \\
(0.082 \mathrm{~kW}) \text { and less than } 1 \mathrm{hp}(0.746 \mathrm{~kW}) \text { shall be } \\
\text { electronically commutated motors or shall have a } \\
\text { minimum motor efficiency of } 70 \text { percent, rated in } \\
\text { accordance with DOE } 10 \mathrm{CFR} 431 \text {. These motors } \\
\text { shall also have the means to adjust motor speed for } \\
\text { either balancing or remote control. The use of } \\
\text { beltdriven fans to sheave adjustments for airflow } \\
\text { balancing instead of a varying motor speed shall be } \\
\text { permitted. Exceptions: The following motors are not } \\
\text { required to comply with this section: } 1 \text {. Motors in } \\
\text { the airstream within fan coils and terminal units } \\
\text { that only provide heating to the space served. } 2 \text {. } \\
\text { Motors in space-conditioning equipment that } \\
\text { comply with Section } 403.2 .3 \text { or C403.2.12. 3. } \\
\text { Motors that comply with Section C405.8. }\end{array}$ \\
\hline 17 & $\begin{array}{c}\text { Heat pump } \\
\text { supplemental } \\
\text { heat lockout }\end{array}$ & $6.3 .2 \mathrm{~h}$ & Criteria & $\begin{array}{l}\text { h. If a heat pump equipped with auxiliary } \\
\text { internal electric resistance heaters is installed, } \\
\text { controls shall be provided that prevent } \\
\text { supplemental heater operation when the } \\
\text { heating load can be met by the heat pump } \\
\text { alone during both steady-state operation and } \\
\text { setback recovery. Supplemental heater } \\
\text { operation is permitted during outdoor coil } \\
\text { defrost cycles. The heat pump must be } \\
\text { controlled by either (1) a digital or electronic } \\
\text { thermostat designed for heat-pump use that } \\
\text { energizes auxiliary heat only when the heat } \\
\text { pump has insufficient capacity to maintain } \\
\text { setpoint or to warm up the space at a } \\
\text { sufficient rate or (2) a multistage space } \\
\text { thermostat and an outdoor air thermostat } \\
\text { wired to energize auxiliary heat only on the } \\
\text { last stage of the space thermostat and when } \\
\text { outdoor air temperature is less than } 40^{\circ} \mathrm{F} \text {. }\end{array}$ & NA & NA & NA \\
\hline
\end{tabular}




\begin{tabular}{|c|c|c|c|c|c|c|c|}
\hline & Measure & $\begin{array}{l}\text { Std } \\
90.1- \\
2013 \\
\text { Section } \\
\text { Number }\end{array}$ & $\begin{array}{l}\text { Std 90.1-2013 } \\
\text { Section Title }\end{array}$ & Std 90.1-2013 Requirement & $\begin{array}{l}2015 \text { IECC } \\
\text { Section } \\
\text { Number }\end{array}$ & $\begin{array}{l}2015 \text { IECC } \\
\text { Section Title }\end{array}$ & 2015 IECC Requirement \\
\hline & $\begin{array}{l}\text { Heat pump } \\
\text { supplemental } \\
\text { heat lockout }\end{array}$ & 6.4 .3 .5 & $\begin{array}{l}\text { Heat Pump } \\
\text { Auxiliary Heat } \\
\text { Control }\end{array}$ & $\begin{array}{l}\text { Heat pumps equipped with internal electric } \\
\text { resistance heaters shall have controls that } \\
\text { prevent supplemental heater operation when } \\
\text { the heating load can be met by the heat } \\
\text { pump alone during both steady-state } \\
\text { operation and setback recovery. } \\
\text { Supplemental heater operation is permitted } \\
\text { during outdoor coil defrost cycles. Exception: } \\
\text { Heat pumps whose minimum efficiency is } \\
\text { regulated by NAECA and whose ratings meet } \\
\text { the requirements shown in Table } 6.8 .1-2 \text { and } \\
\text { include all usage of internal electric resistance } \\
\text { heating. }\end{array}$ & C403.2.4.1.1 & $\begin{array}{l}\text { Heat pump } \\
\text { supplementary } \\
\text { heat }\end{array}$ & $\begin{array}{l}\text { Heat pumps having supplementary electric } \\
\text { resistance heat shall have controls that, except } \\
\text { during defrost, prevent supplementary heat } \\
\text { operation where the heat pump can provide the } \\
\text { heating load. }\end{array}$ \\
\hline \multirow[b]{2}{*}{18} & $\begin{array}{l}\text { Heat rejection } \\
\text { fan variable- } \\
\text { flow controls }\end{array}$ & 6.5 .5 .2 .1 & [No Title] & $\begin{array}{l}\text { Each fan powered by a motor of } 7.5 \mathrm{hp} \text { or } \\
\text { larger shall have the capability to operate at } \\
\text { two-thirds full speed or less and shall have } \\
\text { controls that automatically change the fan } \\
\text { speed to control the leaving fluid temperature } \\
\text { or condensing temperature/pressure of the } \\
\text { heat rejection device. Exceptions: } 1 \text {. } \\
\text { Condenser fans serving multiple refrigerant } \\
\text { circuits } 2 \text {. Condenser fans serving flooded } \\
\text { condensers } 3 \text {. Installations located in Climate } \\
\text { zones } 1 \text { and } 2 \text {. }\end{array}$ & C403.4.3.2.1 & $\begin{array}{l}\text { Fan motors } \\
\text { not less than } \\
7.5 \mathrm{hp} .\end{array}$ & $\begin{array}{l}\text { Each fan powered by a motor of } 7.5 \mathrm{hp}(5.6 \mathrm{~kW}) \text { or } \\
\text { larger shall have the capability to operate that fan } \\
\text { at two-thirds of full speed or less, and shall have } \\
\text { controls that automatically change the fan speed to } \\
\text { control the leaving fluid temperature or condensing } \\
\text { temperature/pressure of the heat rejection device } \\
\text { Exception: The following fan motors over } 7.5 \mathrm{hp} \\
(5.6 \mathrm{~kW}) \text { are exempt: } 1 \text {. Condenser fans serving } \\
\text { multiple refrigerant circuits. } 2 \text {. Condenser fans } \\
\text { serving flooded condensers. } 3 \text {. Installations located } \\
\text { in Climate zones } 1 \text { and } 2 \text {. }\end{array}$ \\
\hline & $\begin{array}{l}\text { Heat rejection } \\
\text { fan variable- } \\
\text { flow controls }\end{array}$ & 6.5.5.2.2 & [No Title] & $\begin{array}{l}\text { Multicell heat rejection equipment with } \\
\text { variable-speed fan drives shall a. operate the } \\
\text { maximum number of fans allowed that } \\
\text { comply with the manufacturer's requirements } \\
\text { for all system components and b. control all } \\
\text { fans to the same fan speed required for the } \\
\text { instantaneous cooling duty, as opposed to } \\
\text { staged (on/off) operation. Minimum fan } \\
\text { speed shall comply with the minimum } \\
\text { allowable speed of the fan drive system per } \\
\text { the manufacturer's recommendations. }\end{array}$ & C403.4.3.2.2 & $\begin{array}{l}\text { Multiple-cell } \\
\text { heat rejection } \\
\text { equipment. }\end{array}$ & $\begin{array}{l}\text { Multiple-cell heat rejection equipment with variable } \\
\text { speed fan drives shall be controlled in both of the } \\
\text { following manners: } 1 \text {. To operate the maximum } \\
\text { number of fans allowed that comply with the } \\
\text { manufacturer's requirements for all system } \\
\text { components. } 2 \text {. So all fans can operate at the same } \\
\text { fan speed required for the instantaneous cooling } \\
\text { duty, as } \\
\text { opposed to staged (on/off) operation. Minimum fan } \\
\text { speed shall be the minimum allowable } \\
\text { speed of the fan drive system in accordance with } \\
\text { the manufacturer's recommendations. }\end{array}$ \\
\hline 19 & $\begin{array}{l}\text { Humidity } \\
\text { control } \\
\text { limitations }\end{array}$ & $6.3 .2 \mathrm{i}$ & Criteria & $\begin{array}{l}\text { i. The system controls shall not permit reheat } \\
\text { or any other form of simultaneous heating } \\
\text { and cooling for humidity control. }\end{array}$ & NA & NA & NA \\
\hline
\end{tabular}




\begin{tabular}{|c|c|c|c|c|c|c|}
\hline Measure & $\begin{array}{l}\text { Std } \\
90.1- \\
2013 \\
\text { Section } \\
\text { Number }\end{array}$ & $\begin{array}{l}\text { Std 90.1-2013 } \\
\text { Section Title }\end{array}$ & Std 90.1-2013 Requirement & $\begin{array}{l}2015 \text { IECC } \\
\text { Section } \\
\text { Number }\end{array}$ & $\begin{array}{l}2015 \text { IECC } \\
\text { Section Title }\end{array}$ & 2015 IECC Requirement \\
\hline $\begin{array}{l}\text { Humidity } \\
\text { control } \\
\text { limitations }\end{array}$ & 6.5 .2 .3 & Dehumidification & $\begin{array}{l}\text { Where humidity controls are provided, such } \\
\text { controls shall prevent reheating, mixing of hot } \\
\text { and cold airstreams, or other means of } \\
\text { simultaneous heating and cooling of the same } \\
\text { airstream. Exceptions: } 1 \text {. The system is } \\
\text { configured to reduce supply air volume to } \\
50 \% \text { or less of the design airlow rate or the } \\
\text { minimum outdoor air ventilation rate } \\
\text { specified in ASHRAE Standard } 62.1 \text { or other } \\
\text { applicable federal, state, or local code or } \\
\text { recognized standard, whichever is larger, } \\
\text { before simultaneous heating and cooling } \\
\text { takes place. } 2 \text {. The individual fan cooling unit } \\
\text { has a design cooling capacity of } 65,000 \text { Btu/h } \\
\text { or less and is capable of unloading to } 50 \% \\
\text { capacity before simultaneous heating and } \\
\text { cooling takes place. } 3 \text {. The individual } \\
\text { mechanical cooling unit has a design cooling } \\
\text { capacity of } 40,000 \text { Btu/h or less. An individual } \\
\text { mechanical cooling unit is a single system } \\
\text { composed of a fan or fans and a cooling coil } \\
\text { capable of providing mechanical cooling. } 4 . \\
\text { Systems serving spaces where specific } \\
\text { humidity levels are required to satisfy process } \\
\text { needs, such as vivariums, museums, surgical } \\
\text { suites, pharmacies, and buildings with } \\
\text { refrigerating systems, such as supermarkets, } \\
\text { refrigerated warehouses, and ice arenas, and } \\
\text { the building includes site-recovered or site } \\
\text { solar energy source that provide energy equal } \\
\text { to at least } 75 \% \text { of the annual energy for } \\
\text { reheating or for providing warm air in mixing } \\
\text { systems. This exception does not apply to } \\
\text { computer rooms. } 5 \text {. At least } 90 \% \text { of the } \\
\text { annual energy for reheating or for providing } \\
\text { warm air in mixing systems is provided from a } \\
\text { site-recovered (including condenser heat) or } \\
\text { site solar energy source. } 6 \text {. Systems where the } \\
\text { heat added to the airstream is the result of } \\
\text { the use of a desiccant system and } 75 \% \text { of the } \\
\text { heat added by the desiccant system is } \\
\text { removed by a heat exchanger, either before }\end{array}$ & NA & NA & NA \\
\hline
\end{tabular}




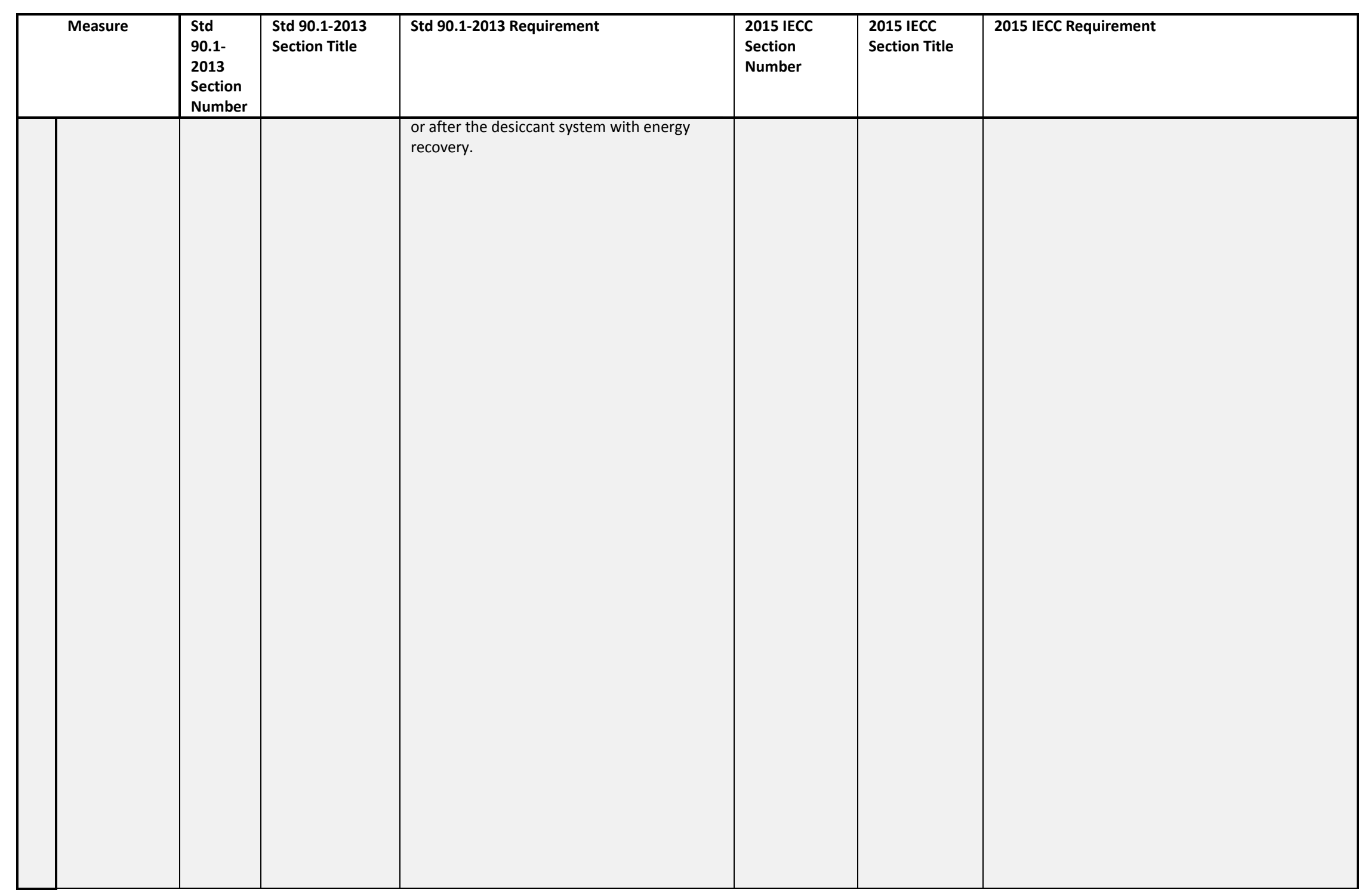




\begin{tabular}{|c|c|c|c|c|c|c|}
\hline Measure & $\begin{array}{l}\text { Std } \\
90.1- \\
2013 \\
\text { Section } \\
\text { Number }\end{array}$ & $\begin{array}{l}\text { Std 90.1-2013 } \\
\text { Section Title }\end{array}$ & Std 90.1-2013 Requirement & $\begin{array}{l}2015 \text { IECC } \\
\text { Section } \\
\text { Number }\end{array}$ & $\begin{array}{l}2015 \text { IECC } \\
\text { Section Title }\end{array}$ & 2015 IECC Requirement \\
\hline $\begin{array}{l}\text { Humidity } \\
\text { control } \\
\text { limitations }\end{array}$ & 6.4 .3 .6 & $\begin{array}{l}\text { Humidification } \\
\text { and } \\
\text { Dehumidification }\end{array}$ & $\begin{array}{l}\text { Humidity control shall prevent the use of } \\
\text { fossil fuel or electricity to produce RH above } \\
30 \% \text { in the warmest zone served by the } \\
\text { humidification system and to reduce RH } \\
\text { below } 60 \% \text { in the coldest zone served by the } \\
\text { dehumidification system. Where a zone is } \\
\text { served by a system or systems with both } \\
\text { humidification and dehumidification } \\
\text { capability, means (such as limit switches, } \\
\text { mechanical stops, or, for DDC systems, } \\
\text { software programming) shall be provided } \\
\text { capable of preventing simultaneous operation } \\
\text { of humidification and dehumidification } \\
\text { equipment. Exceptions: } 1 \text {. Zones served by } \\
\text { desiccant systems, used with direct } \\
\text { evaporative cooling in series } 2 \text {. Systems } \\
\text { serving zones where specific humidity levels } \\
\text { are required, such as museums and hospitals, } \\
\text { and approved by the authority having } \\
\text { jurisdiction or required by accreditation } \\
\text { standards and humidity controls are } \\
\text { configured to maintain a deadband of at least } \\
10 \% \text { RH where no active humidification or } \\
\text { dehumidification takes place } 3 \text {. Systems } \\
\text { serving zones where humidity levels are } \\
\text { required to be maintained with precision of } \\
\text { not more than } \pm 5 \% \text { RH to comply with } \\
\text { applicable codes or accreditation standards or } \\
\text { as approved by the authority having } \\
\text { jurisdiction. }\end{array}$ & C403.2.4.1 & $\begin{array}{l}\text { Thermostatic } \\
\text { controls }\end{array}$ & $\begin{array}{l}\text { The supply of heating and cooling energy to each } \\
\text { zone shall be controlled by individual thermostatic } \\
\text { controls capable of responding to temperature } \\
\text { within the zone. Where humidification or } \\
\text { dehumidification or both is provided, at least one } \\
\text { humidity control device shall be provided for each } \\
\text { humidity control system. }\end{array}$ \\
\hline
\end{tabular}




\begin{tabular}{|c|c|c|c|c|c|c|c|}
\hline & Measure & $\begin{array}{l}\text { Std } \\
90.1- \\
2013 \\
\text { Section } \\
\text { Number }\end{array}$ & $\begin{array}{l}\text { Std 90.1-2013 } \\
\text { Section Title }\end{array}$ & Std 90.1-2013 Requirement & $\begin{array}{l}2015 \text { IECC } \\
\text { Section } \\
\text { Number }\end{array}$ & $\begin{array}{l}2015 \text { IECC } \\
\text { Section Title }\end{array}$ & 2015 IECC Requirement \\
\hline 20 & $\begin{array}{l}\mathrm{HW} \text { and } \mathrm{CW} \\
\text { temperature } \\
\text { reset controls }\end{array}$ & 6.5 .4 .4 & $\begin{array}{l}\text { Chilled - and Hot } \\
\text { Water } \\
\text { Temperature } \\
\text { Reset Controls }\end{array}$ & $\begin{array}{l}\text { Chilled- and hot water systems with a design } \\
\text { capacity exceeding } 300,000 \text { Btu/h supplying } \\
\text { chilled or heated water (or both) to comfort } \\
\text { conditioning systems shall include controls } \\
\text { that automatically reset supply water } \\
\text { temperatures by representative building } \\
\text { loads (including return water temperature) or } \\
\text { by outdoor air temperature. Exceptions: } 1 \text {. } \\
\text { Where the supply temperature reset controls } \\
\text { cannot be implemented without causing } \\
\text { improper operation of heating, cooling, } \\
\text { humidifying, or dehumidifying systems } 2 \text {. } \\
\text { Hydronic systems, such as those required by } \\
\text { Section } 6.5 .4 .1 \text {, that use variable flow to } \\
\text { reduce pumping energy. }\end{array}$ & C403.4.2.4 & $\begin{array}{l}\text { Part-load } \\
\text { controls. }\end{array}$ & $\begin{array}{l}\text { Hydronic systems greater than or equal to } 500,000 \\
\text { Btu/h ( } 146.5 \mathrm{~kW} \text { ) in design output capacity } \\
\text { supplying heated or chilled water to comfort } \\
\text { conditioning systems shall include controls that } \\
\text { have the capability to do all of the following: } 1 \text {. } \\
\text { Automatically reset the supply-water temperatures } \\
\text { in response to varying building heating and cooling } \\
\text { demand using coil valve position, zone return water } \\
\text { temperature, building-return water temperature or } \\
\text { outside air temperature. The temperature shall be } \\
\text { capable of being reset by not less than } 25 \text { percent } \\
\text { of the design supply-to return water temperature } \\
\text { difference. } 2 \text {. Automatically vary fluid flow for } \\
\text { hydronic systems with a combined motor capacity } \\
\text { of } 10 \text { hp (7.5 kW) or larger with three or more } \\
\text { control valves or other devices by reducing the } \\
\text { system design flow rate by not less than } 50 \text { percent } \\
\text { by designed valves that modulate or step open and } \\
\text { close, or pumps that modulate or turn on and off as } \\
\text { a function of load. } 3 \text {. Automatically vary pump flow } \\
\text { on chilled-water systems and heat rejection loops } \\
\text { serving water-cooled unitary air conditioners with a } \\
\text { combined motor capacity of } 10 \text { hp ( } 7.5 \text { kW) or } \\
\text { larger by reducing pump design flow by not less } \\
\text { than } 50 \text { percent, utilizing adjustable speed drives on } \\
\text { pumps, or multiple-staged pumps where not less } \\
\text { than one-half of the total pump horsepower is } \\
\text { capable of being automatically turned off. Pump } \\
\text { flow shall be controlled to maintain one control } \\
\text { valve nearly wide open or to satisfy the minimum } \\
\text { differential pressure. Exceptions: } 1 \text {. Supply-water } \\
\text { temperature reset for chilled-water systems } \\
\text { supplied by off-site district chilled water or chilled } \\
\text { water from ice storage systems. } 2 \text {. Minimum flow } \\
\text { rates other than } 50 \text { percent as required by the } \\
\text { equipment manufacturer for proper operation of } \\
\text { equipment where using flow bypass or end-of-line } \\
3 \text {-way valves. } 3 \text {. Variable pump flow on dedicated } \\
\text { equipment circulation pumps where configured in } \\
\text { primary/secondary design to provide the minimum } \\
\text { flow requirements of the equipment manufacturer } \\
\text { for proper operation of equipment. }\end{array}$ \\
\hline
\end{tabular}




\begin{tabular}{|c|c|c|c|c|c|c|c|}
\hline & Measure & $\begin{array}{l}\text { Std } \\
90.1- \\
2013 \\
\text { Section } \\
\text { Number }\end{array}$ & $\begin{array}{l}\text { Std 90.1-2013 } \\
\text { Section Title }\end{array}$ & Std 90.1-2013 Requirement & $\begin{array}{l}2015 \text { IECC } \\
\text { Section } \\
\text { Number }\end{array}$ & $\begin{array}{l}2015 \text { IECC } \\
\text { Section Title }\end{array}$ & 2015 IECC Requirement \\
\hline 21 & $\begin{array}{c}\text { Kitchen } \\
\text { demand } \\
\text { ventilation } \\
\text { controls }\end{array}$ & 6.5.7.1.4 & [No Title] & $\begin{array}{l}\text { If a kitchen/dining facility has a total kitchen } \\
\text { hood exhaust airflow rate greater than } 5000 \\
\text { ffm then it shall have one of the following: a. } \\
\text { At least } 50 \% \text { of all replacement air is transfer } \\
\text { air that would otherwise be exhausted. b. } \\
\text { Demand ventilation system(s) on at least } 75 \% \\
\text { of the exhaust air. Such systems shall be } \\
\text { capable of at least } 50 \% \text { reduction in exhaust } \\
\text { and replacement air system airflow rates, } \\
\text { including controls necessary to modulate } \\
\text { airflow in response to appliance operation } \\
\text { and to maintain full capture and containment } \\
\text { of smoke, effluent, and combustion products } \\
\text { during cooking and idle. c. Listed energy } \\
\text { recovery devices with a sensible heat } \\
\text { recovery effectiveness of not less than } 40 \% \\
\text { on at least } 50 \% \text { of the total exhaust airflow. }\end{array}$ & C403.2.8 & $\begin{array}{l}\text { Kitchen } \\
\text { exhaust } \\
\text { systems. }\end{array}$ & $\begin{array}{l}\text { Replacement air introduced directly into the } \\
\text { exhaust hood cavity shall not be greater than } 10 \\
\text { percent of the hood exhaust airflow rate. } \\
\text { Conditioned supply air delivered to any space shall } \\
\text { not exceed the greater of the following: } 1 \text {. The } \\
\text { ventilation rate required to meet the space heating } \\
\text { or cooling load. } 2 \text {. The hood exhaust flow minus the } \\
\text { available transfer air from adjacent space where } \\
\text { available transfer air is considered that portion of } \\
\text { outdoor ventilation air not required to satisfy other } \\
\text { exhaust needs, such as restrooms, and not required } \\
\text { to maintain pressurization of adjacent spaces. } \\
\text { Where total kitchen hood exhaust airflow rate is } \\
\text { greater than } 5,000 \text { cfm (2360 L/s), each hood shall } \\
\text { be a factory built commercial exhaust hood listed by } \\
\text { a nationally recognized testing laboratory in } \\
\text { compliance with UL } 710 \text {. Each hood shall have a } \\
\text { maximum exhaust rate as specified in Table } 403.2 .8 \\
\text { and shall comply with one of the following: } 1 \text {. Not } \\
\text { less than } 50 \text { percent of all replacement air shall be } \\
\text { transfer air that would otherwise be exhausted. } 2 \text {. } \\
\text { Demand ventilation systems on not less than } 75 \\
\text { percent of the exhaust air that are capable of not } \\
\text { less than a } 50 \text {-percent reduction in exhaust and } \\
\text { replacement air system airflow rates, including } \\
\text { controls necessary to modulate airllow in response } \\
\text { to appliance operation and to maintain full capture } \\
\text { and containment of smoke, effluent and } \\
\text { combustion products during cooking and idle. } 3 \text {. } \\
\text { Listed energy recovery devices with a sensible heat } \\
\text { recovery effectiveness of not less than } 40 \text { percent } \\
\text { on not less than } 50 \text { percent of the total exhaust } \\
\text { airflow. Where a single hood, or hood section, is } \\
\text { installed over appliances with different duty ratings, } \\
\text { the maximum allowable flow rate for the hood or } \\
\text { hood section shall be based on the requirements for } \\
\text { the highest appliance duty rating under the hood or } \\
\text { hood section. Exception: Where not less than } 75 \\
\text { percent of all the replacement air is transfer air that } \\
\text { would otherwise be exhausted. }\end{array}$ \\
\hline
\end{tabular}




\begin{tabular}{|c|c|c|c|c|c|c|c|}
\hline & Measure & $\begin{array}{l}\text { Std } \\
90.1- \\
2013 \\
\text { Section }\end{array}$ & $\begin{array}{l}\text { Std 90.1-2013 } \\
\text { Section Title }\end{array}$ & Std 90.1-2013 Requirement & $\begin{array}{l}2015 \text { IECC } \\
\text { Section } \\
\text { Number }\end{array}$ & $\begin{array}{l}2015 \text { IECC } \\
\text { Section Title }\end{array}$ & 2015 IECC Requirement \\
\hline 22 & $\begin{array}{l}\text { Laboratory } \\
\text { exhaust hood } \\
\text { flow control }\end{array}$ & 6.5 .7 .2 & $\begin{array}{l}\text { Laboratory } \\
\text { Exhaust Systems }\end{array}$ & $\begin{array}{l}\text { Buildings with laboratory exhaust systems } \\
\text { having a total exhaust rate greater than } 5000 \\
\text { cfm shall include at least one of the following } \\
\text { features: a. VAV laboratory exhaust and room } \\
\text { supply system capable of reducing exhaust } \\
\text { and makeup airflow rates and/or incorporate } \\
\text { a heat recovery system to precondition } \\
\text { makeup air from laboratory exhaust that shall } \\
\text { meet the following: } A+B \times(E / M)^{3} 50 \% \\
\text { where } A=\text { percentage that the exhaust and } \\
\text { makeup airflow rates can be reduced from } \\
\text { design conditions } B=\text { percentage sensible } \\
\text { recovery effectiveness } \mathrm{E}=\text { exhaust airflow } \\
\text { rate through the heat recovery device at } \\
\text { design conditions } \mathrm{M}=\text { makeup airflow rate of } \\
\text { the system at design conditions. b. VAV } \\
\text { laboratory exhaust and room supply systems } \\
\text { that are required to have minimum } \\
\text { circulation rates to comply with code or } \\
\text { accreditation standards shall be capable of } \\
\text { reducing zone exhaust and makeup airflow } \\
\text { rates to the regulated minimum circulation } \\
\text { values or the minimum required to maintain } \\
\text { pressurization relationship requirements. } \\
\text { Nonregulated zones shall be capable of } \\
\text { reducing exhaust and makeup airflow rates to } \\
50 \% \text { of the zone design values or the } \\
\text { minimum required to maintain pressurization } \\
\text { relationship requirements. c. Direct makeup } \\
\text { (auxiliary) air supply equal to at least } 75 \% \text { of } \\
\text { the exhaust airflow rate, heated no warmer } \\
\text { than } 2^{\circ} \mathrm{F} \text { below room setpoint, cooled to no } \\
\text { cooler than } 3^{\circ} \mathrm{F} \text { above room setpoint, no } \\
\text { humidification added, and no simultaneous } \\
\text { heating and cooling used for dehumidification } \\
\text { control. }\end{array}$ & NA & NA & NA \\
\hline
\end{tabular}




\begin{tabular}{|c|c|c|c|c|c|c|c|}
\hline & Measure & $\begin{array}{l}\text { Std } \\
90.1- \\
2013 \\
\text { Section } \\
\text { Number }\end{array}$ & $\begin{array}{l}\text { Std 90.1-2013 } \\
\text { Section Title }\end{array}$ & Std 90.1-2013 Requirement & $\begin{array}{l}2015 \text { IECC } \\
\text { Section } \\
\text { Number }\end{array}$ & $\begin{array}{l}2015 \text { IECC } \\
\text { Section Title }\end{array}$ & 2015 IECC Requirement \\
\hline 23 & $\begin{array}{l}\text { Limits on } \\
\text { simulataneous } \\
\text { heating and } \\
\text { cooling - } \\
\text { airside }\end{array}$ & 6.5 .2 .1 & Zone Controls & $\begin{array}{l}\text { Zone thermostatic controls shall prevent a. } \\
\text { reheating; b. recooling; c. mixing or } \\
\text { simultaneously supplying air that has been } \\
\text { previously mechanically heated and air that } \\
\text { has been previously cooled, either by } \\
\text { mechanical cooling or by economizer } \\
\text { systems; and d. other simultaneous operation } \\
\text { of heating and cooling systems to the same } \\
\text { zone. Exceptions: } 1 \text {. Zones without DDC for } \\
\text { which the volume of air that is reheated, } \\
\text { recooled, or mixed is less than the larger of } \\
\text { the following: a. } 30 \% \text { of the zone design peak } \\
\text { supply rate b. The outdoor airflow rate } \\
\text { required to meet the ventilation } \\
\text { requirements of ASHRAE Standard } 62.1 \text { for } \\
\text { the zone c. Any higher rate that can be } \\
\text { demonstrated, to the satisfaction of the } \\
\text { authority having jurisdiction, to reduce overall } \\
\text { system annual energy usage by offsetting } \\
\text { reheat/recool energy losses through a } \\
\text { reduction in outdoor air intake for the system } \\
\text { d. The airflowrate required to comply with } \\
\text { applicable codes or accreditation standards, } \\
\text { such as pressure relationships or minimum air } \\
\text { change rates } 2 \text {. Zones with DDC that comply } \\
\text { with all of the following: a. The airflow rate in } \\
\text { dead band between heating and cooling does } \\
\text { not exceed the larger of the following: (1) } \\
20 \% \text { of the zone design peak supply rate (2) } \\
\text { The outdoor airflow rate required to meet the } \\
\text { ventilation requirements of ASHRAE Standard } \\
62.1 \text { for the zone (3) Any higher rate that can } \\
\text { be demonstrated, to the satisfaction of the } \\
\text { authority having jurisdiction, to reduce overall } \\
\text { system annual energy usage by offsetting } \\
\text { reheat/recool energy losses through a } \\
\text { reduction in outdoor air intake (4) The airflow } \\
\text { rate required to comply with applicable codes } \\
\text { or accreditation standards, such as pressure } \\
\text { relationships or minimum air change rates b. } \\
\text { The airflow rate that is reheated, recooled, or } \\
\text { mixed shall be less than50\%of the zone }\end{array}$ & C403.4.4 & $\begin{array}{l}\text { Requirements } \\
\text { for complex } \\
\text { mechanical } \\
\text { systems } \\
\text { serving } \\
\text { multiple zones. }\end{array}$ & $\begin{array}{l}\text { Sections C403.4.4.1 through C403.4.6.4 shall apply } \\
\text { to complex mechanical systems serving multiple } \\
\text { zones. Supply air systems serving multiple zones } \\
\text { shall be VAV systems that, during periods of } \\
\text { occupancy, are designed and capable of being } \\
\text { controlled to reduce primary air supply to each } \\
\text { zone to one of the following before reheating, } \\
\text { recooling or mixing takes place: } 1 \text {. Thirty percent of } \\
\text { the maximum supply air to each zone. } 2 \text {. Three } \\
\text { hundred cfm (142 L/s) or less where the maximum } \\
\text { flow rate is less than } 10 \text { percent of the total fan } \\
\text { system supply airflow rate. } 3 \text {. The minimum } \\
\text { ventilation requirements of Chapter } 4 \text { of the } \\
\text { International Mechanical Code. } 4 \text {. Any higher rate } \\
\text { that can be demonstrated to reduce overall system } \\
\text { annual energy use by offsetting reheat/recool } \\
\text { energy losses through a reduction in outdoor air } \\
\text { intake for the system, as approved by the code } \\
\text { official. } 5 \text {. The airflow rate required to comply with } \\
\text { applicable codes or accreditation standards, such as } \\
\text { pressure relationships or minimum air change rates. } \\
\text { Exception: The following individual zones or entire } \\
\text { air distribution systems are exempted from the } \\
\text { requirement for VAV control: } 1 \text {. Zones or supply air } \\
\text { systems where not less than } 75 \text { percent of the } \\
\text { energy for reheating or for providing warm air in } \\
\text { mixing systems is provided from a site-recovered or } \\
\text { site solar energy source. } 2 \text {. Zones where special } \\
\text { humidity levels are required to satisfy process } \\
\text { needs. } 3 . \text { Zones with a peak supply air quantity of } \\
300 \text { cfm ( } 142 \text { L/s) or less and where the flow rate is } \\
\text { less than } 10 \text { percent of the total fan system supply } \\
\text { airflow rate. } 4 \text {. Zones where the volume of air to be } \\
\text { reheated, recooled or mixed is not greater than the } \\
\text { volume of outside air required to provide the } \\
\text { minimum ventilation requirements of Chapter } 4 \text { of } \\
\text { the International Mechanical Code. } 5 \text {. Zones or } \\
\text { supply air systems with thermostatic and } \\
\text { humidistatic controls capable of operating in } \\
\text { sequence the supply of heating and cooling energy } \\
\text { to the zones and which are capable of preventing } \\
\text { reheating, recooling, mixing or simultaneous supply }\end{array}$ \\
\hline
\end{tabular}




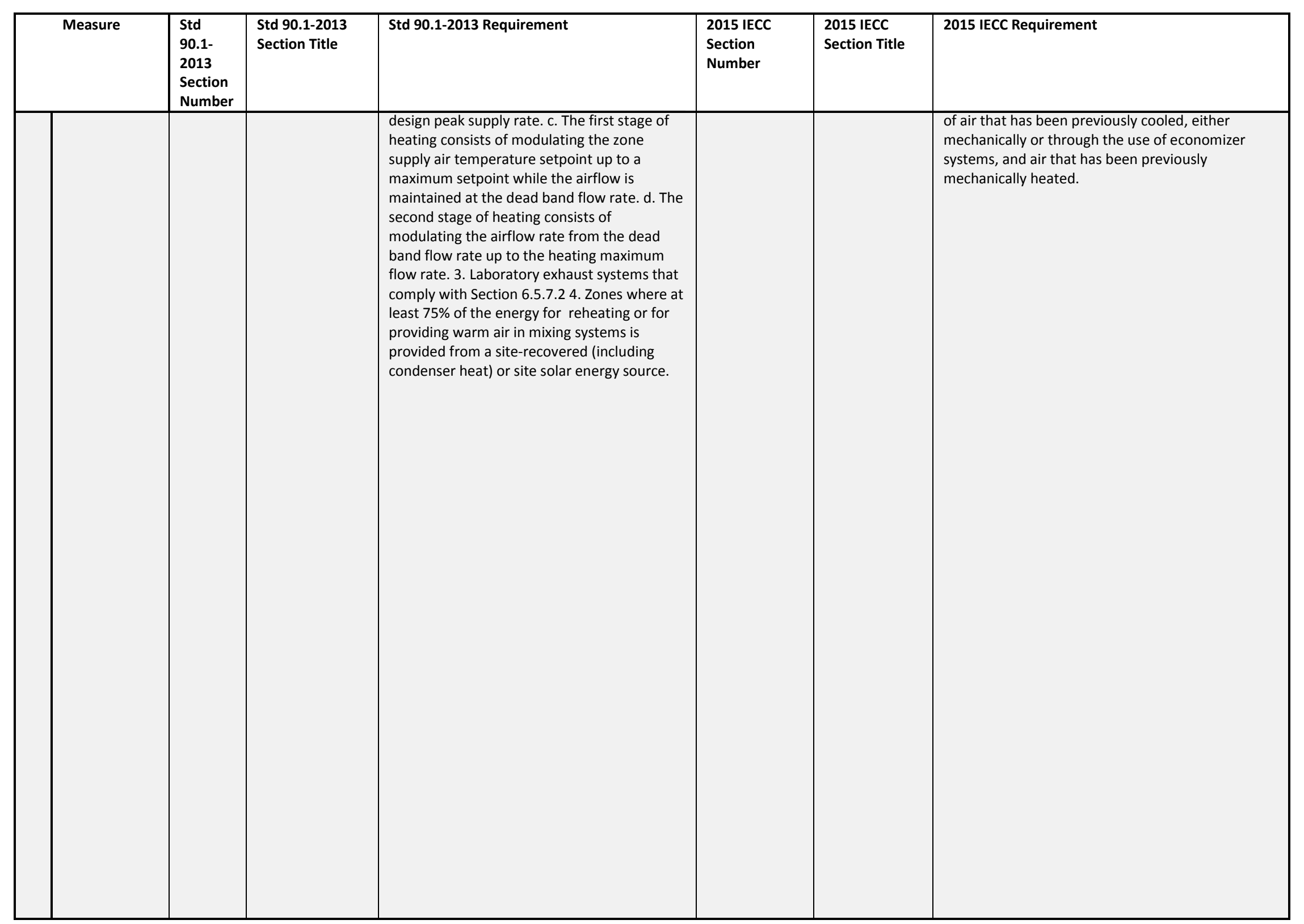




\begin{tabular}{|c|c|c|c|c|c|c|c|}
\hline & Measure & $\begin{array}{l}\text { Std } \\
90.1- \\
2013 \\
\text { Section } \\
\text { Number }\end{array}$ & $\begin{array}{l}\text { Std 90.1-2013 } \\
\text { Section Title }\end{array}$ & Std 90.1-2013 Requirement & $\begin{array}{l}2015 \text { IECC } \\
\text { Section } \\
\text { Number }\end{array}$ & $\begin{array}{l}2015 \text { IECC } \\
\text { Section Title }\end{array}$ & 2015 IECC Requirement \\
\hline \multirow[b]{2}{*}{24} & $\begin{array}{l}\text { Limits on } \\
\text { simulataneous } \\
\text { heating and } \\
\text { cooling - } \\
\text { water-side }\end{array}$ & 6.5 .2 .2 & $\begin{array}{l}\text { Hydronic System } \\
\text { Controls }\end{array}$ & $\begin{array}{l}\text { The heating of fluids in hydronic systems that } \\
\text { have been previously mechanically cooled } \\
\text { and the cooling of fluids that have been } \\
\text { previously mechanically heated shall be } \\
\text { limited in accordance with Sections } 6.5 .2 .2 .1 \\
\text { through 6.5.2.2.3. }\end{array}$ & C403.4.2 & $\begin{array}{l}\text { Hydronic } \\
\text { systems } \\
\text { controls. }\end{array}$ & $\begin{array}{l}\text { The heating of fluids that have been previously } \\
\text { mechanically cooled and the cooling of fluids that } \\
\text { have been previously mechanically heated shall be } \\
\text { limited in accordance with Sections C403.4.2.1 } \\
\text { through C } 403.4 .2 .3 \text {. Hydronic heating systems } \\
\text { comprised of multiple-packaged boilers and } \\
\text { designed to deliver conditioned water or steam into } \\
\text { a common distribution system shall include } \\
\text { automatic controls capable of sequencing operation } \\
\text { of the boilers. Hydronic heating systems comprised } \\
\text { of a single boiler and greater than } 500,000 \text { Btu/h } \\
\text { (146.5 kW) input design capacity shall include either } \\
\text { a multistaged or modulating burner. }\end{array}$ \\
\hline & $\begin{array}{l}\text { Limits on } \\
\text { simulataneous } \\
\text { heating and } \\
\text { cooling - } \\
\text { water-side }\end{array}$ & 6.5 .2 .2 .2 & $\begin{array}{l}\text { Two-Pipe } \\
\text { Changeover } \\
\text { System }\end{array}$ & $\begin{array}{l}\text { Systems that use a common distribution } \\
\text { system to supply both heated and chilled } \\
\text { water are acceptable provided all of the } \\
\text { following are met: a. The system is designed } \\
\text { to allow a dead band between changeover } \\
\text { from one mode to the other of at least } 15^{\circ} \mathrm{F} \\
\text { outdoor air temperature. b. The system is } \\
\text { designed to operate and is provided with } \\
\text { controls that will allow operation in one mode } \\
\text { for at least four hours before changing over to } \\
\text { the other mode. c. Reset controls are } \\
\text { provided that allow heating and cooling } \\
\text { supply temperatures at the changeover point } \\
\text { to be no more than } 30^{\circ} \mathrm{F} \text { apart. }\end{array}$ & C403.4.2.2 & $\begin{array}{l}\text { Two-pipe } \\
\text { changeover } \\
\text { system. }\end{array}$ & $\begin{array}{l}\text { Systems that use a common distribution system to } \\
\text { supply both heated and chilled water shall be } \\
\text { designed to allow a dead band between changeover } \\
\text { from one mode to the other of not less than } 15^{\circ} \mathrm{F} \\
\left(8.3^{\circ} \mathrm{C}\right) \text { outside air temperatures; be designed to } \\
\text { and provided with controls that will allow operation } \\
\text { in one mode for not less than } 4 \text { hours before } \\
\text { changing over to the other mode; and be provided } \\
\text { with controls that allow heating and cooling supply } \\
\text { temperatures at the changeover point to be not } \\
\text { more than } 30^{\circ} \mathrm{F}\left(16.7^{\circ} \mathrm{C}\right) \text { apart. }\end{array}$ \\
\hline \multirow{2}{*}{25} & $\begin{array}{l}\text { Occupant- } \\
\text { based interior } \\
\text { lighting } \\
\text { controls }\end{array}$ & $9.4 .1 .1 \mathrm{~b}$ & $\begin{array}{l}\text { Interior Lighting } \\
\text { Controls }\end{array}$ & $\begin{array}{l}\text { b. Restricted to manual ON: None of the } \\
\text { lighting shall be automatically turned on. } \\
\text { Exception: Manual ON is not required where } \\
\text { manual ON operation of the general lighting } \\
\text { would endanger the safety or security of the } \\
\text { room or building occupants. }\end{array}$ & NA & NA & NA \\
\hline & $\begin{array}{l}\text { Occupant- } \\
\text { based interior } \\
\text { lighting } \\
\text { controls }\end{array}$ & 9.4.1.1c & $\begin{array}{l}\text { Interior Lighting } \\
\text { Controls }\end{array}$ & $\begin{array}{l}\text { c. Restricted to partial automatic ON: No } \\
\text { more than } 50 \% \text { of the lighting power for the } \\
\text { general lighting shall be allowed to be } \\
\text { automatically turned on, and none of the } \\
\text { remaining lighting shall be automatically } \\
\text { turned on. }\end{array}$ & NA & NA & NA \\
\hline
\end{tabular}




\begin{tabular}{|c|c|c|c|c|c|c|}
\hline Measure & $\begin{array}{l}\text { Std } \\
90.1- \\
2013 \\
\text { Section } \\
\text { Number }\end{array}$ & $\begin{array}{l}\text { Std } 90.1-2013 \\
\text { Section Title }\end{array}$ & Std 90.1-2013 Requirement & $\begin{array}{l}2015 \text { IECC } \\
\text { Section } \\
\text { Number }\end{array}$ & $\begin{array}{l}2015 \text { IECC } \\
\text { Section Title }\end{array}$ & 2015 IECC Requirement \\
\hline $\begin{array}{l}\text { Occupant- } \\
\text { based interior } \\
\text { lighting } \\
\text { controls }\end{array}$ & $9.4 .1 .1 \mathrm{~g}$ & $\begin{array}{l}\text { Interior Lighting } \\
\text { Controls }\end{array}$ & $\begin{array}{l}\text { g. Automatic partial OFF (full OFF complies): } \\
\text { The general lighting power in the space shall } \\
\text { be automatically reduced by at least } 50 \% \\
\text { within } 20 \text { minutes of all occupants leaving the } \\
\text { space. Exceptions: This requirement does not } \\
\text { have to be complied with in spaces that meet } \\
\text { all three of the following requirements: } 1 \text {. The } \\
\text { space has an LPD of no more than } 0.80 \mathrm{~W} / \mathrm{ft} 2 \\
2 \text {. The space is lighted by HID } 3 \text {. The general } \\
\text { lighting power in the space is automatically } \\
\text { reduced by at least } 30 \% \text { within } 20 \text { minutes of } \\
\text { all occupants leaving the space. }\end{array}$ & C405.2.1 & $\begin{array}{l}\text { Occupant } \\
\text { sensor controls }\end{array}$ & $\begin{array}{l}\text { Occupant sensor controls shall be installed to } \\
\text { control lights in the following space types: } 1 . \\
\text { Classrooms/lecture/training rooms. } 2 \text {. } \\
\text { Conference/meeting/multipurpose rooms. } 3 \text {. } \\
\text { Copy/print rooms. } 4 \text {. Lounges. } 5 \text {. Employee lunch } \\
\text { and break rooms. } 6 \text {. Private offices. } 7 \text {. Restrooms. } 8 \text {. } \\
\text { Storage rooms. } 9 \text {. Janitorial closets. } 10 \text {. Locker } \\
\text { rooms. } 11 \text {. Other spaces } 300 \text { square feet }\left(28 \mathrm{~m}^{2}\right) \text { or } \\
\text { less that are enclosed by floor-to-ceiling height } \\
\text { partitions. } 12 \text {. Warehouses. }\end{array}$ \\
\hline $\begin{array}{l}\text { Occupant- } \\
\text { based interior } \\
\text { lighting } \\
\text { controls }\end{array}$ & 9.4.1.1h & $\begin{array}{l}\text { Interior Lighting } \\
\text { Controls }\end{array}$ & $\begin{array}{l}\text { h. Automatic full OFF: All lighting shall be } \\
\text { automatically shut off within } 20 \text { minutes of all } \\
\text { occupants leaving the space. A control device } \\
\text { meeting this requirement shall control no } \\
\text { more than } 5000 \mathrm{ft} 2 \text {. Exceptions: The following } \\
\text { lighting is not required to be automatically } \\
\text { shut off: } 1 \text {. General lighting and task lighting } \\
\text { in shop and laboratory classrooms } 2 \text {. General } \\
\text { lighting and task lighting in spaces where } \\
\text { automatic shutoff would endanger the safety } \\
\text { or security of room or building occupants } 3 \text {. } \\
\text { Lighting required for } 24 / 7 \text { operation. }\end{array}$ & C405.2.1.1 & $\begin{array}{l}\text { Occupant } \\
\text { sensor control } \\
\text { function. }\end{array}$ & $\begin{array}{l}\text { Occupant sensor controls in spaces other than } \\
\text { warehouses specified in Section C405.2.1 shall } \\
\text { comply with the following: } 1 \text {. Automatically turn off } \\
\text { lights within } 30 \text { minutes of all occupants leaving the } \\
\text { space. } 2 \text {. Be manual on or controlled to } \\
\text { automatically turn the lighting on to not more than } \\
50 \text { percent power. Exception: Full automatic ON } \\
\text { controls shall be permitted to control lighting in } \\
\text { public corridors, stairways, restrooms, primary } \\
\text { building entrance areas and lobbies, and areas } \\
\text { where manual ON operation would endanger the } \\
\text { safety or security of the room or building } \\
\text { occupants. 3. Shall incorporate a manual control to } \\
\text { allow occupants to turn lights off. }\end{array}$ \\
\hline $\begin{array}{l}\text { Occupant- } \\
\text { based interior } \\
\text { lighting } \\
\text { controls }\end{array}$ & NA & NA & NA & C405.2.1.2 & $\begin{array}{l}\text { Occupant } \\
\text { sensor control } \\
\text { function in } \\
\text { warehouses. }\end{array}$ & $\begin{array}{l}\text { In warehouses, the lighting in aisleways and open } \\
\text { areas shall be controlled with occupant sensors that } \\
\text { automatically reduce lighting power by not less } \\
\text { than } 50 \text { percent when the areas are unoccupied. } \\
\text { The occupant sensors shall control lighting in each } \\
\text { aisleway independently and shall not control } \\
\text { lighting beyond the aisleway being controlled by the } \\
\text { sensor. }\end{array}$ \\
\hline
\end{tabular}




\begin{tabular}{|c|c|c|c|c|c|c|}
\hline Measure & $\begin{array}{l}\text { Std } \\
90.1- \\
2013 \\
\text { Section } \\
\text { Number }\end{array}$ & $\begin{array}{l}\text { Std } 90.1-2013 \\
\text { Section Title }\end{array}$ & Std 90.1-2013 Requirement & $\begin{array}{l}2015 \text { IECC } \\
\text { Section } \\
\text { Number }\end{array}$ & $\begin{array}{l}2015 \text { IECC } \\
\text { Section Title }\end{array}$ & 2015 IECC Requirement \\
\hline $\begin{array}{l}\text { Occupant- } \\
\text { based interior } \\
\text { lighting } \\
\text { controls }\end{array}$ & 9.4 .1 .3 & $\begin{array}{l}\text { Special } \\
\text { Applications }\end{array}$ & $\begin{array}{l}\text { a. The following lighting shall be separately } \\
\text { controlled from the general lighting in all } \\
\text { spaces: } 1 \text {. Display or accent lighting } 2 \text {. Lighting } \\
\text { in display cases } 3 \text {. Nonvisual lighting, such as } \\
\text { for plant growth or food warming } 4 \text {. Lighting } \\
\text { equipment that is for sale or used for } \\
\text { demonstrations in lighting education b. } \\
\text { Guestrooms } 1 \text {. All lighting and all switched } \\
\text { receptacles in guestrooms and suites in } \\
\text { hotels, motels, boarding houses, or similar } \\
\text { buildings shall be automatically controlled } \\
\text { such that the power to the lighting and } \\
\text { switched receptacles in each enclosed space } \\
\text { will be turned off within } 20 \text { minutes after all } \\
\text { occupants leave that space. Exception: } \\
\text { Enclosed spaces where the lighting and } \\
\text { switched receptacles are controlled by } \\
\text { captive key systems and bathrooms are } \\
\text { exempt. } 2 \text {. Bathrooms shall have a separate } \\
\text { control device installed to automatically turn } \\
\text { off the bathroom lighting within } 30 \text { minutes } \\
\text { after all occupants have left the bathroom. } \\
\text { Exception: Night lighting of up to } 5 \mathrm{~W} \text { per } \\
\text { bathroom is exempt. c. All supplemental task } \\
\text { lighting, including permanently installed } \\
\text { undershelf or undercabinet lighting, shall be } \\
\text { controlled from either (1) a control device } \\
\text { integral to the luminaires or (2) by a wall- } \\
\text { mounted control device that is readily } \\
\text { accessible and located so that the occupant } \\
\text { can see the controlled lighting. }\end{array}$ & C405.2.4 & $\begin{array}{l}\text { Specific } \\
\text { application } \\
\text { controls. }\end{array}$ & $\begin{array}{l}\text { Specific application controls shall be provided for } \\
\text { the following: } 1 \text {. Display and accent light shall be } \\
\text { controlled by a dedicated control that is } \\
\text { independent of the controls for other lighting } \\
\text { within the room or space.2. Lighting in cases used } \\
\text { for display case purposes shall be controlled by a } \\
\text { dedicated control that is independent of the } \\
\text { controls for other lighting within the room or space. } \\
\text { 3. Hotel and motel sleeping units and guest suites } \\
\text { shall have a master control device that is capable of } \\
\text { automatically switching off all installed luminaires } \\
\text { and switched receptacles within } 20 \text { minutes after all } \\
\text { occupants leave the room. Exception: Lighting and } \\
\text { switched receptacles controlled by captive key } \\
\text { systems. } 4 \text {. Supplemental task lighting, including } \\
\text { permanently installed undershelf or undercabinet } \\
\text { lighting, shall have a control device integral to the } \\
\text { luminaires or be controlled by a wall-mounted } \\
\text { control device provided that the control device is } \\
\text { readily accessible. } 5 \text {. Lighting for nonvisual } \\
\text { applications, such as plant growth and food } \\
\text { warming, shall be controlled by a dedicated control } \\
\text { that is independent of the controls for other lighting } \\
\text { within the room or space. } 6 \text {. Lighting equipment } \\
\text { that is for sale or for demonstrations in lighting } \\
\text { education shall be controlled by a dedicated control } \\
\text { that is independent of the controls for other lighting } \\
\text { within the room or space. }\end{array}$ \\
\hline
\end{tabular}




\begin{tabular}{|c|c|c|c|c|c|c|c|}
\hline & Measure & $\begin{array}{l}\text { Std } \\
90.1- \\
2013 \\
\text { Section } \\
\text { Number }\end{array}$ & $\begin{array}{l}\text { Std 90.1-2013 } \\
\text { Section Title }\end{array}$ & Std 90.1-2013 Requirement & $\begin{array}{l}2015 \text { IECC } \\
\text { Section } \\
\text { Number }\end{array}$ & $\begin{array}{l}2015 \text { IECC } \\
\text { Section Title }\end{array}$ & 2015 IECC Requirement \\
\hline 26 & $\begin{array}{c}\text { Occupant- } \\
\text { based } \\
\text { receptacle } \\
\text { control }\end{array}$ & 8.4 .2 & $\begin{array}{l}\text { Automatic } \\
\text { Receptacle } \\
\text { Control }\end{array}$ & $\begin{array}{l}\text { The following shall be automatically } \\
\text { controlled: a. At least } 50 \% \text { of all } 125 \text {-volt } 15- \\
\text { and 20-amp receptacles in all private offices, } \\
\text { conference rooms, rooms used primarily for } \\
\text { printing and/or copying functions, break } \\
\text { rooms, classsooms, and individual } \\
\text { workstations b. . la least } 25 \% \text { of branch circuit } \\
\text { feeders installed for modular furniture not } \\
\text { shown on the construction documents. This } \\
\text { control shall function on a. a scheduled basis } \\
\text { using a time-of-day operated control device } \\
\text { that turns receptacles off at specific } \\
\text { programmed times -an independent } \\
\text { program schedule shall be provided for } \\
\text { controlled areas of no more than } 5000 \text { ft2 and } \\
\text { not more than one floor (the occupant shall } \\
\text { be able to manually override the control } \\
\text { device for up to two hours), b. an occupant } \\
\text { sensor that shall turn receptacles off within } \\
20 \text { minutes of all occupants leaving a space, } \\
\text { or c. an automated signal from another } \\
\text { control or alarm system that shall turn } \\
\text { receptacles off within } 20 \text { minutes after } \\
\text { determining that the area is unoccupied. All } \\
\text { controlled receptacles shall be permanently } \\
\text { marked to visually differentiate them from } \\
\text { uncontrolled receptacles and are to be } \\
\text { uniformly distributed throughout the space. } \\
\text { Plug-in devices shall not be used to comply } \\
\text { with Section } 8.4 .2 \text {. Exceptions: Receptacles } \\
\text { for the following shall not require an } \\
\text { automatic control device: } 1 \text {. Receptacles } \\
\text { specifically designated for equipment } \\
\text { requiring continuous operation (24 } \\
\text { hours/day, } 365 \text { days/year) } 2 \text {. Spaces where an } \\
\text { automatic control would endanger the safety } \\
\text { or security of the room or building } \\
\text { occupant(s). }\end{array}$ & NA & NA & NA \\
\hline
\end{tabular}




\begin{tabular}{|c|c|c|c|c|c|c|c|}
\hline \multicolumn{2}{|r|}{ Measure } & $\begin{array}{l}\text { Std } \\
90.1- \\
2013 \\
\text { Section } \\
\text { Number }\end{array}$ & $\begin{array}{l}\text { Std 90.1-2013 } \\
\text { Section Title }\end{array}$ & Std 90.1-2013 Requirement & $\begin{array}{l}2015 \text { IECC } \\
\text { Section } \\
\text { Number }\end{array}$ & $\begin{array}{l}2015 \text { IECC } \\
\text { Section Title }\end{array}$ & 2015 IECC Requirement \\
\hline & $\begin{array}{l}\text { Off-hour } \\
\text { automatic } \\
\text { temperature } \\
\text { setback and } \\
\text { system } \\
\text { shutoff with } \\
\text { manual } \\
\text { override } \\
\end{array}$ & 6.4 .3 .3 & $\begin{array}{l}\text { Off-Hour } \\
\text { Controls }\end{array}$ & $\begin{array}{l}\text { HVAC systems shall have the off-hour controls } \\
\text { required by Sections } 6.4 .3 .3 .1 \text { through } \\
\text { 6.4.3.3.4. Exceptions: } 1 \text {. HVAC systems } \\
\text { intended to operate continuously } 2 \text {. HVAC } \\
\text { systems having a design heating capacity and } \\
\text { cooling capacity less than } 15,000 \text { Btu/h that } \\
\text { are equipped with readily accessible manual } \\
\text { on/off controls. }\end{array}$ & C403.2.4.2 & $\begin{array}{l}\text { Off-hour } \\
\text { controls }\end{array}$ & $\begin{array}{l}\text { Each zone shall be provided with thermostatic } \\
\text { setback controls that are controlled by either an } \\
\text { automatic time clock or programmable control } \\
\text { system. Exceptions: } 1 \text {. Zones that will be operated } \\
\text { continuously.2. Zones with a full HVAC load demand } \\
\text { not exceeding } 6,800 \mathrm{Btu} / \mathrm{h}(2 \mathrm{~kW}) \text { and having a } \\
\text { readily accessible manual shutoff switch. }\end{array}$ \\
\hline 27 & $\begin{array}{l}\text { Off-hour } \\
\text { automatic } \\
\text { temperature } \\
\text { setback and } \\
\text { system } \\
\text { shutoff with } \\
\text { manual } \\
\text { override }\end{array}$ & 6.4.3.3.1 & $\begin{array}{l}\text { Automatic } \\
\text { Shutdown }\end{array}$ & $\begin{array}{l}\text { HVAC systems shall be equipped with at least } \\
\text { one of the following: a. Controls that can start } \\
\text { and stop the system under different time } \\
\text { schedules for seven different day types per } \\
\text { week, are capable of retaining programming } \\
\text { and time setting during loss of power for a } \\
\text { period of at least ten hours, and include an } \\
\text { accessible manual override, or equivalent } \\
\text { function, that allows temporary operation of } \\
\text { the system for up to two hours b. An } \\
\text { occupant sensor that is capable of shutting } \\
\text { the system off when no occupant is sensed } \\
\text { for a period of up to } 30 \text { minutes c. A manually } \\
\text { operated timer capable of being adjusted to } \\
\text { operate the system for up to two hours d. An } \\
\text { interlock to a security system that shuts the } \\
\text { system off when the security system is } \\
\text { activated Exception: Residential occupancies } \\
\text { may use controls that can start and stop the } \\
\text { system under two different time schedules } \\
\text { per week. }\end{array}$ & C403.2.4.2.2 & $\begin{array}{l}\text { Automatic } \\
\text { setback and } \\
\text { shutdown } \\
\text { capabilities. }\end{array}$ & $\begin{array}{l}\text { Automatic time clock or programmable controls } \\
\text { shall be capable of starting and stopping the system } \\
\text { for seven different daily schedules per week and } \\
\text { retaining their programming and time setting during } \\
\text { a loss of power for at least } 10 \text { hours. Additionally, } \\
\text { the controls shall have a manual override that } \\
\text { allows temporary operation of the system for up to } \\
2 \text { hours; a manually operated timer capable of } \\
\text { being adjusted to operate the system for up to } 2 \\
\text { hours; or an occupancy sensor. }\end{array}$ \\
\hline
\end{tabular}




\begin{tabular}{|c|c|c|c|c|c|c|c|}
\hline \multicolumn{2}{|r|}{ Measure } & $\begin{array}{l}\text { Std } \\
90.1- \\
2013 \\
\text { Section } \\
\text { Number }\end{array}$ & $\begin{array}{l}\text { Std 90.1-2013 } \\
\text { Section Title }\end{array}$ & Std 90.1-2013 Requirement & $\begin{array}{l}2015 \text { IECC } \\
\text { Section } \\
\text { Number }\end{array}$ & $\begin{array}{l}2015 \text { IECC } \\
\text { Section Title }\end{array}$ & 2015 IECC Requirement \\
\hline & $\begin{array}{l}\text { Off-hour } \\
\text { automatic } \\
\text { temperature } \\
\text { setback and } \\
\text { system } \\
\text { shutoff with } \\
\text { manual } \\
\text { override }\end{array}$ & 6.4.3.3.2 & Setback Controls & $\begin{array}{l}\text { Heating systems shall be equipped with } \\
\text { controls configured to automatically restart } \\
\text { and temporarily operate the system as } \\
\text { required to maintain zone temperatures } \\
\text { above an adjustable heating setpoint at least } \\
10^{\circ} \mathrm{F} \text { below the occupied heating setpoint. } \\
\text { Cooling systems shall be equipped with } \\
\text { controls configured to automatically restart } \\
\text { and temporarily operate the mechanical } \\
\text { cooling system as required to maintain zone } \\
\text { temperatures below an adjustable cooling } \\
\text { setpoint at least } 5^{\circ} \mathrm{F} \text { above the occupied } \\
\text { cooling setpoint or to prevent high space } \\
\text { humidity levels. Exception: Radiant heating } \\
\text { systems configured with a setback heating } \\
\text { setpoint at least } 4^{\circ} \mathrm{F} \text { below the occupied } \\
\text { heating setpoint. }\end{array}$ & C403.2.4.2.1 & $\begin{array}{l}\text { Thermostatic } \\
\text { setback } \\
\text { capabilities }\end{array}$ & $\begin{array}{l}\text { Thermostatic setback controls shall have the } \\
\text { capability to set back or temporarily operate the } \\
\text { system to maintain zone temperatures down to } \\
55^{\circ} \mathrm{F}\left(13^{\circ} \mathrm{C}\right) \text { or up to } 85^{\circ} \mathrm{F}\left(29^{\circ} \mathrm{C}\right) \text {. }\end{array}$ \\
\hline & $\begin{array}{c}\text { Off-hour } \\
\text { automatic } \\
\text { temperature } \\
\text { setback and } \\
\text { system } \\
\text { shutoff with } \\
\text { manual } \\
\text { override } \\
\end{array}$ & 6.4.3.4.4 & $\begin{array}{l}\text { Ventilation Fan } \\
\text { Controls }\end{array}$ & $\begin{array}{l}\text { Fans with motors greater than } 0.75 \text { hp shall } \\
\text { have automatic controls complying with } \\
\text { Section 6.4.3.3.1 that are capable of shutting } \\
\text { off fans when not required. Exception: HVAC } \\
\text { systems intended to operate continuously. }\end{array}$ & NA & NA & (May be part of IMC.) \\
\hline 28 & $\begin{array}{l}\text { One } \\
\text { thermostat or } \\
\text { other } \\
\text { temperature } \\
\text { controller per } \\
\text { zone }\end{array}$ & 6.4.3.1.1 & General & $\begin{array}{l}\text { The supply of heating and cooling energy to } \\
\text { each zone shall be individually controlled by } \\
\text { thermostatic controls responding to } \\
\text { temperature within the zone. For the } \\
\text { purposes of this section, a dwelling unit shall } \\
\text { be permitted to be considered a single zone. } \\
\text { Exceptions: Independent perimeter systems } \\
\text { that are designed to offset only building } \\
\text { envelope loads shall be permitted to serve } \\
\text { one or more zones also served by an interior } \\
\text { system, provided that 1. the perimeter } \\
\text { system includes at least one thermostatic } \\
\text { control zone for each building exposure } \\
\text { having exterior walls facing only one } \\
\text { orientation for } 50 \text { contiguous feet or more } \\
\text { and 2. the perimeter system heating and } \\
\text { cooling supply is controlled by a thermostatic }\end{array}$ & C403.2.4.1 & $\begin{array}{l}\text { Thermostatic } \\
\text { controls }\end{array}$ & $\begin{array}{l}\text { The supply of heating and cooling energy to each } \\
\text { zone shall be controlled by individual thermostatic } \\
\text { controls capable of responding to temperature } \\
\text { within the zone. Where humidification or } \\
\text { dehumidification or both is provided, at least one } \\
\text { humidity control device shall be provided for each } \\
\text { humidity control system. Exception: Independent } \\
\text { perimeter systems that are designed to offset only } \\
\text { building envelope heat losses, gains or both serving } \\
\text { one or more perimeter zones also served by an } \\
\text { interior system provided: } 1 \text {. The perimeter system } \\
\text { includes at least one thermostatic control zone for } \\
\text { each building exposure having exterior walls facing } \\
\text { only one orientation (within }+/-45 \text { degrees) }(0.8 \text { rad) } \\
\text { for more than } 50 \text { contiguous feet ( } 15240 \mathrm{~mm} \text { ); and } \\
2 \text {. The perimeter system heating and cooling supply }\end{array}$ \\
\hline
\end{tabular}




\begin{tabular}{|c|c|c|c|c|c|c|c|}
\hline \multicolumn{2}{|r|}{ Measure } & $\begin{array}{l}\text { Std } \\
90.1- \\
2013 \\
\text { Section } \\
\text { Number }\end{array}$ & $\begin{array}{l}\text { Std } 90.1-2013 \\
\text { Section Title }\end{array}$ & Std 90.1-2013 Requirement & $\begin{array}{l}2015 \text { IECC } \\
\text { Section } \\
\text { Number }\end{array}$ & $\begin{array}{l}2015 \text { IECC } \\
\text { Section Title }\end{array}$ & 2015 IECC Requirement \\
\hline & & & & $\begin{array}{l}\text { control(s) located within the zones(s) served } \\
\text { by the system. }\end{array}$ & & & $\begin{array}{l}\text { is controlled by thermostats located within the } \\
\text { zones served by the system. }\end{array}$ \\
\hline 29 & $\begin{array}{l}\text { Open door } \\
\text { lockout of } \\
\text { HVAC }\end{array}$ & $6.3 .2 r$ & Criteria & $\begin{array}{l}\text { r. The system complies with the door switch } \\
\text { requirements in Section 6.5.10. }\end{array}$ & NA & NA & NA \\
\hline 30 & $\begin{array}{l}\text { Open door } \\
\text { lockout of } \\
\text { HVAC }\end{array}$ & 6.5 .10 & Door Switches & $\begin{array}{l}\text { Any conditioned space with a door, including } \\
\text { doors with more than one-half glass, opening } \\
\text { to the outdoors shall be provided with } \\
\text { controls that, when any such door is open, a. } \\
\text { disable mechanical heating or reset the } \\
\text { heating setpoint to } 55^{\circ} \mathrm{F} \text { or lower within five } \\
\text { minutes of the door opening and b. disable } \\
\text { mechanical cooling or reset the cooling } \\
\text { setpoint to } 90^{\circ} \mathrm{F} \text { or greater within five } \\
\text { minutes of the door opening. Mechanical } \\
\text { cooling may remain enabled if outdoor air } \\
\text { temperature is below space temperature. } \\
\text { Exceptions: } 1 \text {. Building entries with automatic } \\
\text { closing devices } 2 \text {. Any space without a } \\
\text { thermostat 3. Alterations to existing buildings } \\
\text { 4. Loading docks. }\end{array}$ & NA & NA & NA \\
\hline 31 & $\begin{array}{l}\text { Optimum } \\
\text { start controls }\end{array}$ & $6.3 .2 p$ & Criteria & $\begin{array}{l}\text { p. Systems with a design supply air capacity } \\
\text { greater than } 10,000 \mathrm{cfm} \text { shall have optimum } \\
\text { start controls. }\end{array}$ & NA & NA & NA \\
\hline
\end{tabular}




\begin{tabular}{|c|c|c|c|c|c|c|c|}
\hline & Measure & $\begin{array}{l}\text { Std } \\
90.1- \\
2013 \\
\text { Section } \\
\text { Number }\end{array}$ & $\begin{array}{l}\text { Std } 90.1-2013 \\
\text { Section Title }\end{array}$ & Std 90.1-2013 Requirement & $\begin{array}{l}2015 \text { IECC } \\
\text { Section } \\
\text { Number }\end{array}$ & $\begin{array}{l}2015 \text { IECC } \\
\text { Section Title }\end{array}$ & 2015 IECC Requirement \\
\hline & $\begin{array}{c}\text { Optimum } \\
\text { start controls }\end{array}$ & 6.4.3.3.3 & $\begin{array}{l}\text { Optimum Start } \\
\text { Controls }\end{array}$ & $\begin{array}{l}\text { Individual heating and cooling systems with } \\
\text { setback controls and DDC shall have optimum } \\
\text { start controls. The control algorithm shall, as } \\
\text { a minimum, be a function of the difference } \\
\text { between space temperature and occupied } \\
\text { setpoint, the outdoor temperature, and the } \\
\text { amount of time prior to scheduled occupancy. } \\
\text { Mass radiant floor slab systems shall } \\
\text { incorporate floor temperature into the } \\
\text { optimum start algorithm. }\end{array}$ & C403.2.4.2.3 & $\begin{array}{l}\text { Automatic } \\
\text { start } \\
\text { capabilities. }\end{array}$ & $\begin{array}{l}\text { Automatic start controls shall be provided for each } \\
\text { HVAC system. The controls shall be capable of } \\
\text { automatically adjusting the daily start time of the } \\
\text { HVAC system in order to bring each space to the } \\
\text { desired occupied temperature immediately prior to } \\
\text { scheduled occupancy. }\end{array}$ \\
\hline 32 & $\begin{array}{l}\text { Parking } \\
\text { garage carbon } \\
\text { monoxide } \\
\text { control of } \\
\text { ventilation } \\
\quad \text { fans }\end{array}$ & 6.4.3.4.5 & $\begin{array}{l}\text { Enclosed Parking } \\
\text { Garage } \\
\text { Ventilation }\end{array}$ & $\begin{array}{l}\text { Enclosed parking garage ventilation systems } \\
\text { shall automatically detect contaminant levels } \\
\text { and stage fans or modulate fan airflow rates } \\
\text { to } 50 \% \text { or less of design capacity, provided } \\
\text { acceptable contaminant levels are } \\
\text { maintained. Exceptions: } 1 \text {. Garages less than } \\
30,000 \mathrm{ft} 2 \text { with ventilation systems that do } \\
\text { not utilize mechanical cooling or mechanical } \\
\text { heating } 2 \text {. Garages that have a garage area to } \\
\text { ventilation system motor nameplate hp ratio } \\
\text { that exceeds } 1500 \mathrm{ft} 2 / \mathrm{hp} \text { and do not utilize } \\
\text { mechanical cooling or mechanical heating. } 3 \text {. } \\
\text { Where not permitted by the authority having } \\
\text { jurisdiction. }\end{array}$ & C403.2.6.2 & $\begin{array}{l}\text { Enclosed } \\
\text { parking garage } \\
\text { ventilation } \\
\text { controls }\end{array}$ & $\begin{array}{l}\text { Enclosed parking garages used for storing or } \\
\text { handling automobiles operating under their own } \\
\text { power shall employ contamination sensing devices } \\
\text { and automatic controls configured to stage fans or } \\
\text { modulate fan average airflow rates to } 50 \text { percent or } \\
\text { less of design capacity, or intermittently operate } \\
\text { fans less than } 20 \text { percent of the occupied time or as } \\
\text { required to maintain acceptable contaminant levels } \\
\text { in accordance with International Mechanical Code } \\
\text { provisions. Failure of contamination sensing devices } \\
\text { shall cause the exhaust fans to operate } \\
\text { continuously at design airflow. Exceptions: } 1 \text {. } \\
\text { Garages with a total exhaust capacity less than } \\
22,500 \mathrm{cfm}(10620 \mathrm{~L} / \mathrm{s}) \text { with ventilation systems } \\
\text { that do not utilize heating or mechanical cooling. } 2 \text {. } \\
\text { Garages that have a garage area to ventilation } \\
\text { system motor nameplate power ratio that exceeds } \\
1125 \mathrm{cfm} / \mathrm{hp}(710 \mathrm{~L} / \mathrm{s} / \mathrm{kW}) \text { and do not utilize } \\
\text { heating or mechanical cooling. }\end{array}$ \\
\hline
\end{tabular}




\begin{tabular}{|c|c|c|c|c|c|c|c|}
\hline & Measure & $\begin{array}{l}\text { Std } \\
90.1- \\
2013 \\
\text { Section } \\
\text { Number }\end{array}$ & $\begin{array}{l}\text { Std } 90.1-2013 \\
\text { Section Title }\end{array}$ & Std 90.1-2013 Requirement & $\begin{array}{l}2015 \text { IECC } \\
\text { Section } \\
\text { Number }\end{array}$ & $\begin{array}{l}2015 \text { IECC } \\
\text { Section Title }\end{array}$ & 2015 IECC Requirement \\
\hline 33 & $\begin{array}{l}\text { Parking } \\
\text { garage } \\
\text { lighting } \\
\text { controls }\end{array}$ & 9.4 .1 .2 & $\begin{array}{l}\text { Parking Garage } \\
\text { Lighting Controls }\end{array}$ & $\begin{array}{l}\text { Lighting for parking garages shall comply with } \\
\text { the following requirements: a. Parking garage } \\
\text { lighting shall have automatic lighting shutoff } \\
\text { per Section } 9.4 .1 .1(i) \text {. b. Lighting power of } \\
\text { each luminaire shall be automatically reduced } \\
\text { by a minimum of } 30 \% \text { when there is no } \\
\text { activity detected within a lighting zone for } 20 \\
\text { minutes. Lighting zones for this requirement } \\
\text { shall be no larger than } 3600 \mathrm{ft} 2 \text {. Exceptions: } \\
\text { The following areas are exempt: } 1 \text {. Daylight } \\
\text { transitions zones and ramps without parking } \\
\text { c. Lighting for covered vehicle entrances and } \\
\text { exits from buildings and parking structures } \\
\text { shall be separately controlled by a device that } \\
\text { automatically reduces the lighting by at least } \\
50 \% \text { from sunset to sunrise. } \text {. The power to } \\
\text { luminaires within } 20 \mathrm{ft} \text { of any perimeter wall } \\
\text { structure that has a net opening-to-wall ratio } \\
\text { of at least } 40 \% \text { and no exterior obstructions } \\
\text { within } 20 \mathrm{ft} \text {, shall be automatically reduced in } \\
\text { response to daylight. Exceptions: Lighting in } \\
\text { the following areas is exempt: } 1 \text {. Lighting in } \\
\text { daylight transitions zones and ramps without } \\
\text { parking. }\end{array}$ & NA & NA & NA \\
\hline 34 & $\begin{array}{c}\text { Refrigerated } \\
\text { display case } \\
\text { controls }\end{array}$ & 6.4 .6 & $\begin{array}{l}\text { Refrigerated } \\
\text { Display Cases }\end{array}$ & $\begin{array}{l}\text { b. Lighting in refrigerated display cases and } \\
\text { glass doors installed on walkin coolers and } \\
\text { freezers shall be controlled by one of the } \\
\text { following: } 1 \text {. Automatic time switch controls } \\
\text { to turn off lights during nonbusiness hours. } \\
\text { Timed overrides for display cases or walkin } \\
\text { coolers and freezers may be used to turn the } \\
\text { lights on for up to one hour and shall } \\
\text { automatically time out to turn the lights off. } \\
2 \text {. Motion sensor controls on each display } \\
\text { case or walkin door section that reduce } \\
\text { lighting power by at least } 50 \% \text { within three } \\
\text { minutes after the area within the sensor } \\
\text { range is vacated. c. All low-temperature } \\
\text { display cases shall incorporate temperature- } \\
\text { based defrost termination control with a } \\
\text { timelimit default. The defrost cycle shall } \\
\text { terminate first on an upper temperature limit }\end{array}$ & C403.2.17 & $\begin{array}{l}\text { Refrigerated } \\
\text { display cases. }\end{array}$ & $\begin{array}{l}\text { Site-assembled or site-constructed refrigerated } \\
\text { display cases shall comply with the following: } 1 \text {. } \\
\text { Lighting and glass doors in refrigerated display cases } \\
\text { shall be controlled by one of the following: } 1.1 . \\
\text { Time switch controls to turn off lights during } \\
\text { nonbusiness hours. Timed overrides for display } \\
\text { cases shall turn the lights on for up to } 1 \text { hour and } \\
\text { shall automatically time out to turn the lights off. } \\
\text { 1.2. Motion sensor controls on each display case } \\
\text { section that reduce lighting power by at least } 50 \\
\text { percent within } 3 \text { minutes after the area within the } \\
\text { sensor range is vacated. } 2 \text {. Low-temperature display } \\
\text { cases shall incorporate temperature-based defrost } \\
\text { termination control with a time limit default. The } \\
\text { defrost cycle shall terminate first on an upper } \\
\text { temperature limit breach and second upon a time } \\
\text { limit breach. } 3 \text {. Antisweat heater controls shall } \\
\text { reduce the energy use of the antisweat heater as a }\end{array}$ \\
\hline
\end{tabular}




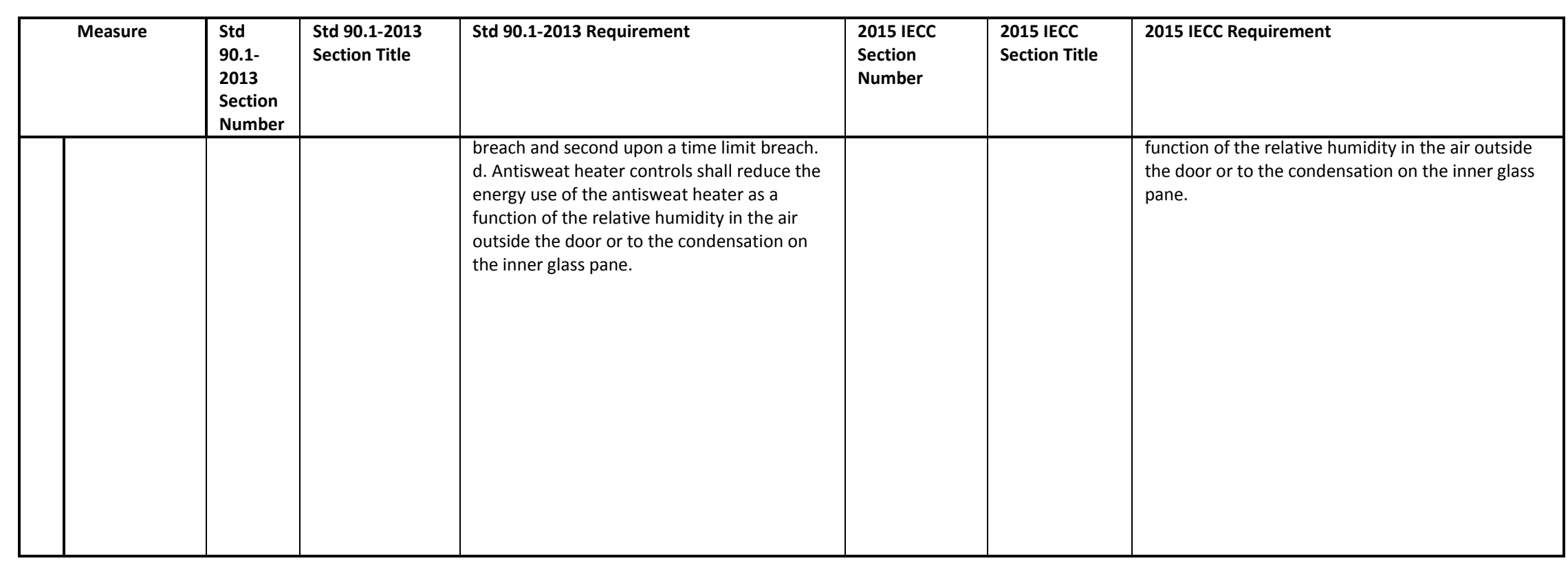




\begin{tabular}{|c|c|c|c|c|c|c|c|}
\hline & Measure & $\begin{array}{l}\text { Std } \\
90.1- \\
2013 \\
\text { Section } \\
\text { Number }\end{array}$ & $\begin{array}{l}\text { Std 90.1-2013 } \\
\text { Section Title }\end{array}$ & Std 90.1-2013 Requirement & $\begin{array}{l}2015 \text { IECC } \\
\text { Section } \\
\text { Number }\end{array}$ & $\begin{array}{l}2015 \text { IECC } \\
\text { Section Title }\end{array}$ & 2015 IECC Requirement \\
\hline 35 & $\begin{array}{l}\text { Refrigeration } \\
\text { system } \\
\text { compressor } \\
\text { controls }\end{array}$ & 6.5 .11 .2 & $\begin{array}{l}\text { Compressor } \\
\text { Systems }\end{array}$ & $\begin{array}{l}\text { Refrigeration compressor systems shall } \\
\text { conform to the following requirements: a. } \\
\text { Compressors and multiple-compressor } \\
\text { systems suction groups shall include control } \\
\text { systems that use floating suction pressure } \\
\text { control logic to reset the target suction } \\
\text { pressure temperature based on the } \\
\text { temperature requirements of the attached } \\
\text { refrigeration display cases or walk-ins. } \\
\text { Exceptions: } 1 \text {. Single-compressor systems that } \\
\text { do not have variable capacity capability } 2 \text {. } \\
\text { Suction groups that have a design saturated } \\
\text { suction temperature equal to or greater than } \\
30^{\circ} \mathrm{F} \text {, suction groups that comprise the high } \\
\text { stage of a two-stage or cascade system, or } \\
\text { suction groups that primarily serve chillers for } \\
\text { secondary cooling fluids. b. Liquid subcooling } \\
\text { shall be provided for all low-temperature } \\
\text { compressor systems with a design cooling } \\
\text { capacity equal to or greater than } 100,000 \\
\text { Btu/h with a design saturated suction } \\
\text { temperature equal to or less than }-10^{\circ} \mathrm{F} \text {. The } \\
\text { subcooled liquid temperature shall be } \\
\text { controlled at a maximum temperature } \\
\text { setpoint of } 50^{\circ} \mathrm{F} \text { at the exit of the subcooler } \\
\text { using either compressor economizer } \\
\text { (interstage) ports or a separate compressor } \\
\text { suction group operating at a saturated suction } \\
\text { temperature equal to or greater than } 18^{\circ} \mathrm{F} \text {. } 1 . \\
\text { Subcooled liquid lines are subject to the } \\
\text { insulation requirements of Table } 6.8 .3-2 \text {. c. All } \\
\text { compressors that incorporate internal or } \\
\text { external crankcase heaters shall provide a } \\
\text { means to cycle the heaters off during } \\
\text { compressor operation. }\end{array}$ & C403.5.2 & $\begin{array}{l}\text { Compressor } \\
\text { systems. }\end{array}$ & $\begin{array}{l}\text { Refrigeration compressor systems shall comply with } \\
\text { the following: } 1 \text {. Compressors and multiple- } \\
\text { compressor system suction groups shall include } \\
\text { control systems that use } \\
\text { floating suction pressure control logic to reset the } \\
\text { target suction pressure temperature based on the } \\
\text { temperature requirements of the attached } \\
\text { refrigeration display cases or walk-ins. Exception: } \\
\text { Controls are not required for the following: } 1 . \\
\text { Single-compressor systems that do not have } \\
\text { variable capacity capability. } 2 \text {. Suction groups that } \\
\text { have a design saturated suction temperature of } \\
30^{\circ} \mathrm{F}\left(-1.1^{\circ} \mathrm{C}\right) \text { or higher, suction groups that } \\
\text { comprise thehigh stage of a two-stage or cascade } \\
\text { system, or suction groups that primarily serve } \\
\text { chillersfor secondary cooling fluids. } 2 \text {. Liquid } \\
\text { subcooling shall be provided for all low- } \\
\text { temperature compressor systems with a design } \\
\text { cooling capacity equal to or greater than } 100,000 \\
\text { Btu/hr }(29.3 \mathrm{~kW}) \text { with a design saturated suction } \\
\text { temperature of }-10^{\circ} \mathrm{F}\left(-23^{\circ} \mathrm{C}\right) \text { orlower. The } \\
\text { subcooled liquid temperature shall be controlled at } \\
\text { a maximum temperature setpoint of } 50^{\circ} \mathrm{F}\left(10^{\circ} \mathrm{C}\right) \text { at } \\
\text { the exit of the subcooler using either compressor } \\
\text { economizer (interstage) ports or a separate } \\
\text { compressor suction group operating at a saturated } \\
\text { suction temperature of } 18^{\circ} \mathrm{F}\left(-7.8^{\circ} \mathrm{C}\right) \text { or higher. } 2.1 . \\
\text { Insulation for liquid lines with a fluid operating } \\
\text { temperature less than } 60^{\circ} \mathrm{F}\left(15.6^{\circ} \mathrm{C}\right) \text { shall comply } \\
\text { with Table C403.2.10. } 3 . \text { Compressors that } \\
\text { incorporate internal or external crankcase heaters } \\
\text { shall provide a means to cycle the heaters off during } \\
\text { compressor operation. }\end{array}$ \\
\hline
\end{tabular}




\begin{tabular}{|c|c|c|c|c|c|c|c|}
\hline & Measure & $\begin{array}{l}\text { Std } \\
90.1- \\
2013 \\
\text { Section } \\
\text { Number }\end{array}$ & $\begin{array}{l}\text { Std 90.1-2013 } \\
\text { Section Title }\end{array}$ & Std 90.1-2013 Requirement & $\begin{array}{l}2015 \text { IECC } \\
\text { Section } \\
\text { Number }\end{array}$ & $\begin{array}{l}2015 \text { IECC } \\
\text { Section Title }\end{array}$ & 2015 IECC Requirement \\
\hline 36 & $\begin{array}{l}\text { Refrigeration } \\
\text { system } \\
\text { condensor } \\
\text { controls }\end{array}$ & 6.5 .11 .1 & $\begin{array}{l}\text { Condensers } \\
\text { Serving } \\
\text { Refrigeration } \\
\text { Equipment }\end{array}$ & $\begin{array}{l}\text { Fan-powered condensers shall conform to the } \\
\text { following requirements: a. Design saturated } \\
\text { condensing temperatures for air-cooled } \\
\text { condensers shall be less than or equal to the } \\
\text { design dry-bulb temperature plus } 10^{\circ} \mathrm{F} \text { for } \\
\text { low-temperature refrigeration systems and } \\
\text { less than or equal to the design dry-bulb } \\
\text { temperature plus } 15^{\circ} \mathrm{F} \text { for medium } \\
\text { temperature refrigeration systems. } 1 . \\
\text { Saturated condensing temperature for blend } \\
\text { refrigerants shall be determined using the } \\
\text { average of liquid and vapor temperatures as } \\
\text { converted from the condenser drain pressure. } \\
\text { b. Condenser fan motors that are less than } 1 \\
\text { hp shall use electronically commutated } \\
\text { motors, permanent split capacitor-type } \\
\text { motors, or three-phase motors. c. All } \\
\text { condenser fans for air-cooled condensers, } \\
\text { evaporatively cooled condensers, and air- or } \\
\text { water-cooled fluid coolers or cooling towers } \\
\text { shall incorporate one of the following } \\
\text { continuous variable-speed fan control } \\
\text { approaches and shall reduce fan motor } \\
\text { demand to no more than } 30 \% \text { of design } \\
\text { wattage at } 50 \% \text { of design air volume: } 1 . \\
\text { Refrigeration system condenser control for } \\
\text { air-cooled condensers shall use variable } \\
\text { setpoint control logic to reset the condensing } \\
\text { temperature setpoint in response to ambient } \\
\text { dry-bulb temperature. } 2 \text {. Refrigeration system } \\
\text { condenser control for evaporatively cooled } \\
\text { condensers shall use variable setpoint control } \\
\text { logic to reset the condensing temperature } \\
\text { setpoint in response to ambient wet-bulb } \\
\text { temperature. d. Multiple fan condensers shall } \\
\text { be controlled in unison. e. The minimum } \\
\text { condensing temperature setpoint shall be no } \\
\text { greater than } 70^{\circ} \mathrm{F} \text {. }\end{array}$ & C403.5.1 & $\begin{array}{l}\text { Condensers } \\
\text { serving } \\
\text { refrigeration } \\
\text { systems. }\end{array}$ & $\begin{array}{l}\text { Fan-powered condensers shall comply with the } \\
\text { following: } 1 \text {. The design saturated condensing } \\
\text { temperatures for air-cooled condensers shall not } \\
\text { exceed the design } \\
\text { dry-bulb temperature plus } 10^{\circ} \mathrm{F}\left(5.6^{\circ} \mathrm{C}\right) \text { for low- } \\
\text { temperature refrigeration systems, and the design } \\
\text { dry-bulb temperature plus } 15^{\circ} \mathrm{F}\left(8^{\circ} \mathrm{C}\right) \text { for medium } \\
\text { temperature refrigeration systems where the } \\
\text { saturated condensing temperature for blend } \\
\text { refrigerants shall be determined using the average } \\
\text { of liquid and vapor temperatures as converted from } \\
\text { the condenser drain } \\
\text { pressure. } 2 . \text { Condenser fan motors that are less } \\
\text { than } 1 \text { hp ( } 0.75 \mathrm{~kW} \text { ) shall use electronically } \\
\text { commutated motors, permanent split-capacitor- } \\
\text { type motors or } 3 \text {-phase motors. } 3 \text {. Condenser fans } \\
\text { for air-cooled condensers, evaporatively cooled } \\
\text { condensers, air- or water-cooled fluid coolers or } \\
\text { cooling towers shall reduce fan motor demand to } \\
\text { not more than } 30 \text { percent of design wattage at } 50 \\
\text { percent of design air volume, and incorporate one } \\
\text { of the following continuous variable speed fan } \\
\text { control approaches: } 3.1 . \text { Refrigeration system } \\
\text { condenser control for air-cooled condensers shall } \\
\text { use variable setpoint control logic to reset the } \\
\text { condensing temperature setpoint in response to } \\
\text { ambient dry-bulb temperature. } \\
3.2 \text {. Refrigeration system condenser control for } \\
\text { evaporatively cooled condensers shall use } \\
\text { variable setpoint control logic to reset the } \\
\text { condensing temperature setpoint in response to } \\
\text { ambient wet-bulb temperature. } 4 \text {. Multiple fan } \\
\text { condensers shall be controlled in unison. } \\
5 . \text { The minimum condensing temperature setpoint } \\
\left.\text { shall be not greater than } 70^{\circ} \mathrm{F} \text { ( } 21^{\circ} \mathrm{C}\right) \text {. }\end{array}$ \\
\hline
\end{tabular}




\begin{tabular}{|c|c|c|c|c|c|c|c|}
\hline & Measure & $\begin{array}{l}\text { Std } \\
90.1- \\
2013 \\
\text { Section } \\
\text { Number }\end{array}$ & $\begin{array}{l}\text { Std 90.1-2013 } \\
\text { Section Title }\end{array}$ & Std 90.1-2013 Requirement & $\begin{array}{l}2015 \text { IECC } \\
\text { Section } \\
\text { Number }\end{array}$ & $\begin{array}{l}2015 \text { IECC } \\
\text { Section Title }\end{array}$ & 2015 IECC Requirement \\
\hline 37 & $\begin{array}{l}\text { Snow melt } \\
\text { system } \\
\text { control }\end{array}$ & 6.4 .3 .7 & $\begin{array}{l}\text { Freeze } \\
\text { Protection and } \\
\text { Snow/Ice- } \\
\text { Melting Systems }\end{array}$ & $\begin{array}{l}\text { Freeze protection systems, such as heat } \\
\text { tracing of outdoor piping and heat } \\
\text { exchangers, including self-regulating heat } \\
\text { tracing, shall include automatic controls } \\
\text { capable of shutting off the systems when } \\
\text { outdoor air temperatures are above } 40^{\circ} \mathrm{F} \text { or } \\
\text { when the conditions of the protected fluid } \\
\text { will prevent freezing. Snow- and ice-melting } \\
\text { systems shall include automatic controls } \\
\text { capable of shutting off the systems when the } \\
\text { pavement temperature is above } 50^{\circ} \mathrm{F} \text { and no } \\
\text { precipitation is falling, and an automatic or } \\
\text { manual control that will allow shutoff when } \\
\text { the outdoor temperature is above } 40^{\circ} \mathrm{F} \text { so } \\
\text { that the potential for snow or ice } \\
\text { accumulation is negligible. }\end{array}$ & $\begin{array}{l}\text { C403.2.4.5 and } \\
\text { C403.2.4.6 }\end{array}$ & $\begin{array}{l}\text { Snow- and ice- } \\
\text { melt system } \\
\text { controls, } \\
\text { Freeze } \\
\text { protection } \\
\text { system } \\
\text { controls. }\end{array}$ & $\begin{array}{l}\text { Snow- and ice-melting systems shall include } \\
\text { automatic controls capable of shutting off the } \\
\text { system when the pavement temperature is above } \\
50^{\circ} \mathrm{F}\left(10^{\circ} \mathrm{C}\right) \text { and no precipitation is falling and an } \\
\text { automatic or manual control that will allow shutoff } \\
\text { when the outdoor temperature is above } 40^{\circ} \mathrm{F}\left(4^{\circ} \mathrm{C}\right) \text {. } \\
\text { Freeze protection systems, such as heat tracing of } \\
\text { outdoor piping and heat exchangers, including self- } \\
\text { regulating heat tracing, shall include automatic } \\
\text { controls configured to shut off the systems when } \\
\text { outdoor air temperatures are above } 40^{\circ} \mathrm{F}\left(4^{\circ} \mathrm{C}\right) \text { or } \\
\text { when the conditions of the protected fluid will } \\
\text { prevent freezing. }\end{array}$ \\
\hline 38 & $\begin{array}{l}\text { Supply air } \\
\text { temperature } \\
\text { reset - reheat } \\
\text { systems }\end{array}$ & 6.5 .3 .4 & $\begin{array}{l}\text { Supply Air } \\
\text { Temperature } \\
\text { Reset Controls }\end{array}$ & $\begin{array}{l}\text { Multiple-zone HVAC systems must include } \\
\text { controls that automatically reset the supply } \\
\text { air temperature in response to representative } \\
\text { building loads, or to outdoor air temperature. } \\
\text { The controls shall reset the supply air } \\
\text { temperature at least } 25 \% \text { of the difference } \\
\text { between the design supply air temperature } \\
\text { and the design room air temperature. } \\
\text { Controls that adjust the reset based on zone } \\
\text { humidity are allowed. Zones that are } \\
\text { expected to experience relatively constant } \\
\text { loads, such as electronic equipment rooms, } \\
\text { shall be designed for the fully reset supply } \\
\text { temperature. Exceptions: } 1 \text {. Climate Zones 1a, } \\
2 a \text { a, and 3a } 2 \text {. Systems that prevent reheating, } \\
\text { recooling, or mixing of heated and cooled } \\
\text { supply air. } 3 \text {. Systems in which at least } 75 \% \text { of } \\
\text { the energy for reheating (on an annual basis) } \\
\text { is from site-recovered or site solar energy } \\
\text { sources. }\end{array}$ & C403.4.4.5 & $\begin{array}{l}\text { Supply-air } \\
\text { temperature } \\
\text { reset controls. }\end{array}$ & $\begin{array}{l}\text { Multiple-zone HVAC systems shall include controls } \\
\text { that automatically reset the supply-air temperature } \\
\text { in response to representative building loads, or to } \\
\text { outdoor air temperature. The controls shall be } \\
\text { capable of resetting the supply air temperature not } \\
\text { less than } 25 \text { percent of the difference between the } \\
\text { design supply-air temperature and the design room } \\
\text { air temperature. Exceptions: } 1 \text {. Systems that } \\
\text { prevent reheating, recooling or mixing of heated } \\
\text { and cooled supply air. } 2 \text {. Seventy-five percent of the } \\
\text { energy for reheating } \\
\text { is from site-recovered or site solar energy sources. } \\
3 . \text { Zones with peak supply air uantities of } 300 \mathrm{cfm} \\
(142 \mathrm{~L} / \mathrm{s}) \text { or less. }\end{array}$ \\
\hline
\end{tabular}




\begin{tabular}{|c|c|c|c|c|c|c|c|}
\hline & Measure & $\begin{array}{l}\text { Std } \\
90.1- \\
2013 \\
\text { Section } \\
\text { Number }\end{array}$ & $\begin{array}{l}\text { Std 90.1-2013 } \\
\text { Section Title }\end{array}$ & Std 90.1-2013 Requirement & $\begin{array}{l}2015 \text { IECC } \\
\text { Section } \\
\text { Number }\end{array}$ & $\begin{array}{l}2015 \text { IECC } \\
\text { Section Title }\end{array}$ & 2015 IECC Requirement \\
\hline \multirow{4}{*}{39} & $\begin{array}{c}\text { SWH } \\
\text { circulation } \\
\text { loop controls }\end{array}$ & 7.4 .4 .2 & $\begin{array}{l}\text { Temperature } \\
\text { Maintenance } \\
\text { Controls }\end{array}$ & $\begin{array}{l}\text { Systems designed to maintain usage } \\
\text { temperatures in hot water pipes, such as } \\
\text { recirculating hot water systems or heat trace, } \\
\text { shall be equipped with automatic time } \\
\text { switches or other controls that can be set to } \\
\text { switch off the usage temperature } \\
\text { maintenance system during extended periods } \\
\text { when hot water is not required. }\end{array}$ & C404.6 & $\begin{array}{l}\text { Heated-water } \\
\text { circulating and } \\
\text { temperature } \\
\text { maintenance } \\
\text { systems. }\end{array}$ & $\begin{array}{l}\text { Heated-water circulation systems shall be in } \\
\text { accordance with Section C404.6.1. Heat trace } \\
\text { temperature maintenance systems shall be in } \\
\text { accordance with Section C404.6.2. Controls for hot } \\
\text { water storage shall be in accordance with Section } \\
\text { C404.6.3. Automatic controls, temperature sensors } \\
\text { and pumps shall be accessible. Manual controls } \\
\text { shall be readily accessible. }\end{array}$ \\
\hline & $\begin{array}{c}\text { SWH } \\
\text { circulation } \\
\text { loop controls }\end{array}$ & NA & NA & NA & C404.6.2 & $\begin{array}{l}\text { Heat trace } \\
\text { systems }\end{array}$ & $\begin{array}{l}\text { Electric heat trace systems shall comply with IEEE } \\
\text { 515.1. Controls for such systems shall be able to } \\
\text { automatically adjust the energy input to the heat } \\
\text { tracing to maintain the desired water temperature } \\
\text { in the piping in accordance with the times when } \\
\text { heated water is used in the occupancy. Heat trace } \\
\text { shall be arranged to be turned off automatically } \\
\text { when there is no hot water demand. }\end{array}$ \\
\hline & $\begin{array}{c}\text { SWH } \\
\text { circulation } \\
\text { loop controls }\end{array}$ & NA & NA & NA & C404.6.1 & $\begin{array}{l}\text { Circulation } \\
\text { systems }\end{array}$ & $\begin{array}{l}\text { Heated-water circulation systems shall be provided } \\
\text { with a circulation pump. The system return pipe } \\
\text { shall be a dedicated return pipe or a cold-water } \\
\text { supply pipe. Gravity and thermo-syphon circulation } \\
\text { systems shall be prohibited. Controls for circulating } \\
\text { hot water system pumps shall start the pump based } \\
\text { on the identification of a demand for hot water } \\
\text { within the occupancy. The controls shall } \\
\text { automatically turn off the pump when the water in } \\
\text { the circulation loop is at the desired temperature } \\
\text { and when there is no demand for hot water. }\end{array}$ \\
\hline & $\begin{array}{c}\text { SWH } \\
\text { circulation } \\
\text { loop controls }\end{array}$ & NA & NA & NA & C404.7 & $\begin{array}{l}\text { Demand } \\
\text { recirculation } \\
\text { controls. }\end{array}$ & $\begin{array}{l}\text { A water distribution system having one or more } \\
\text { recirculation pumps that pump water from a } \\
\text { heated-water supply pipe back to the heated-water } \\
\text { source through a cold-water supply pipe shall be a } \\
\text { demand recirculation water system. Pumps shall } \\
\text { have controls that comply with both of the } \\
\text { following: } 1 \text {. The control shall start the pump upon } \\
\text { receiving a signal from the action of a user of a } \\
\text { fixture or appliance, sensing the presence of a user } \\
\text { of a fixture or sensing the flow of hot or tempered } \\
\text { water to a fixture fitting or appliance. } 2 \text {. The control } \\
\text { shall limit the temperature of the water entering } \\
\text { the cold-water piping to } 104^{\circ} \mathrm{F}\left(40^{\circ} \mathrm{C}\right) \text {. }\end{array}$ \\
\hline
\end{tabular}




\begin{tabular}{|c|c|c|c|c|c|c|c|}
\hline & Measure & $\begin{array}{l}\text { Std } \\
90.1- \\
2013 \\
\text { Section } \\
\text { Number }\end{array}$ & $\begin{array}{l}\text { Std 90.1-2013 } \\
\text { Section Title }\end{array}$ & Std 90.1-2013 Requirement & $\begin{array}{l}2015 \text { IECC } \\
\text { Section } \\
\text { Number }\end{array}$ & $\begin{array}{l}2015 \text { IECC } \\
\text { Section Title }\end{array}$ & 2015 IECC Requirement \\
\hline 40 & $\begin{array}{l}\text { SWH pressure } \\
\text { booster pump } \\
\text { control }\end{array}$ & 10.4 .2 & $\begin{array}{l}\text { Service Water } \\
\text { Pressure Booster } \\
\text { Systems }\end{array}$ & $\begin{array}{l}\text { Service water pressure booster systems shall } \\
\text { be designed such that a. one or more } \\
\text { pressure sensors shall be used to vary pump } \\
\text { speed and/or start and stop pumps. The } \\
\text { sensor(s) shall either be located near the } \\
\text { critical fixture(s) that determine the pressure } \\
\text { required, or logic shall be employed that } \\
\text { adjusts the setpoint to simulate operation of } \\
\text { remote sensor(s). b. no device(s) shall be } \\
\text { installed for the purpose of reducing the } \\
\text { pressure of all of the water supplied by any } \\
\text { booster system pump or booster system, } \\
\text { except for safety devices. c. no booster } \\
\text { system pumps shall operate when there is no } \\
\text { service water flow. }\end{array}$ & NA & NA & NA \\
\hline 41 & $\begin{array}{l}\text { SWH restroom } \\
\text { outlet } \\
\text { maximum } \\
\text { temperature } \\
\text { controls } \\
\end{array}$ & 7.4 .4 .3 & $\begin{array}{l}\text { Outlet } \\
\text { Temperature } \\
\text { Controls }\end{array}$ & $\begin{array}{l}\text { Temperature controlling means shall be } \\
\text { provided to limit the maximum temperature } \\
\text { of water delivered from lavatory faucets in } \\
\text { public facility restrooms to } 110^{\circ} \mathrm{F} \text {. }\end{array}$ & NA & NA & (May be part of IPC.) \\
\hline \multirow[t]{2}{*}{42} & $\begin{array}{l}\text { SWH storage } \\
\text { temperature } \\
\text { controls }\end{array}$ & 7.4.4.1 & $\begin{array}{l}\text { Temperature } \\
\text { Controls }\end{array}$ & $\begin{array}{l}\text { Temperature controls shall be provided that } \\
\text { allow for storage temperature adjustment } \\
\text { from } 120^{\circ} \mathrm{F} \text { or lower to a maximum } \\
\text { temperature compatible with the intended } \\
\text { use. Exception: When the manufacturers' } \\
\text { installation instructions specify a higher } \\
\text { minimum thermostat setting to minimize } \\
\text { condensation and resulting corrosion. }\end{array}$ & NA & NA & NA \\
\hline & $\begin{array}{l}\text { SWH storage } \\
\text { temperature } \\
\text { controls }\end{array}$ & 7.4.4.4 & $\begin{array}{l}\text { Circulating Pump } \\
\text { Controls }\end{array}$ & $\begin{array}{l}\text { When used to maintain storage tank water } \\
\text { temperature, recirculating pumps shall be } \\
\text { equipped with controls limiting operation to a } \\
\text { period from the start of the heating cycle to a } \\
\text { maximum of five minutes after the end of the } \\
\text { heating cycle. }\end{array}$ & C404.6.3 & $\begin{array}{l}\text { Controls for } \\
\text { hot water } \\
\text { storage. }\end{array}$ & $\begin{array}{l}\text { The controls on pumps that circulate water } \\
\text { between a water heater and a heated-water } \\
\text { storage tank shall limit operation of the pump from } \\
\text { heating cycle start-up to not greater than } 5 \text { minutes } \\
\text { after the end of the cycle. }\end{array}$ \\
\hline
\end{tabular}




\begin{tabular}{|c|c|c|c|c|c|c|c|}
\hline & Measure & $\begin{array}{l}\text { Std } \\
90.1- \\
2013 \\
\text { Section } \\
\text { Number }\end{array}$ & $\begin{array}{l}\text { Std 90.1-2013 } \\
\text { Section Title }\end{array}$ & Std 90.1-2013 Requirement & $\begin{array}{l}2015 \text { IECC } \\
\text { Section } \\
\text { Number }\end{array}$ & $\begin{array}{l}2015 \text { IECC } \\
\text { Section Title }\end{array}$ & 2015 IECC Requirement \\
\hline & $\begin{array}{c}\text { SWH storage } \\
\text { temperature } \\
\text { controls }\end{array}$ & 7.4.5.3 & Time Switches & $\begin{array}{l}\text { Time switches shall be installed on swimming } \\
\text { pool heaters and pumps. Exceptions: } 1 . \\
\text { Where public health standards require } 24- \\
\text { hour pump operation } 2 \text {. Where pumps are } \\
\text { required to operate solar and waste-heat- } \\
\text { recovery pool heating systems. }\end{array}$ & C404.9.2 & Time switches. & $\begin{array}{l}\text { Time switches or other control methods that can } \\
\text { automatically turn off and on heaters and pump } \\
\text { motors according to a preset schedule shall be } \\
\text { installed for heaters and pump motors. Heaters and } \\
\text { pump motors that have built-in time switches shall } \\
\text { be in compliance with this section. Exceptions: } 1 \text {. } \\
\text { Where public health standards require } 24 \text {-hour } \\
\text { pump operation. } 2 \text {. Pumps that operate solar- and } \\
\text { waste-heat-recovery pool heating systems. }\end{array}$ \\
\hline 43 & $\begin{array}{c}\text { Timer-based } \\
\text { interior } \\
\text { lighting } \\
\text { controls }\end{array}$ & 9.4.1.1i & $\begin{array}{l}\text { Interior Lighting } \\
\text { Controls }\end{array}$ & $\begin{array}{l}\text { i. Scheduled shutoff: All lighting in the space } \\
\text { not exempted by Exception (1) to Section } \\
9.1 .1 \text { shall be automatically shut off during } \\
\text { periods when the space is scheduled to be } \\
\text { unoccupied using either (1) a time-of-day } \\
\text { operated control device that automatically } \\
\text { turns the lighting off at specific programmed } \\
\text { times or (2) a signal from another automatic } \\
\text { control device or alarm/security system. The } \\
\text { control device or system shall provide } \\
\text { independent control sequences that (1) } \\
\text { control the lighting for an area of no more } \\
\text { than } 25,000 \text { ft2, ( } 2 \text { ) include no more than one } \\
\text { floor, and (3) shall be programmed to account } \\
\text { for weekends and holidays. Any manual } \\
\text { control installed to provide override of the } \\
\text { scheduled shutoff control shall not turn the } \\
\text { lighting on for more than two hours per } \\
\text { activation during scheduled off periods and } \\
\text { shall not control more than } 5000 \mathrm{ft} 2 \text {. } \\
\text { Exceptions: The following lighting is not } \\
\text { required to be on scheduled shutoff: } 1 . \\
\text { Lighting in spaces where lighting is required } \\
\text { for } 24 / 7 \text { continuous operation } 2 \text {. Lighting in } \\
\text { spaces where patient care is rendered } 3 \text {. } \\
\text { Lighting in spaces where automatic shutoff } \\
\text { would endanger the safety or security of the } \\
\text { room or building occupants. }\end{array}$ & C405.2.2 & $\begin{array}{l}\text { Time switch } \\
\text { controls. }\end{array}$ & $\begin{array}{l}\text { Each area of the building that is not provided with } \\
\text { occupant sensor controls complying with Section } \\
\text { C405.2.1.1 shall be provided with time switch } \\
\text { controls complying with Section C405.2.2.1. } \\
\text { Exception: Where a manual control provides light } \\
\text { reduction in accordance with Section C405.2.2.2, } \\
\text { automatic controls shall not be required for the } \\
\text { following: } 1 \text {. Sleeping units. } 2 \text {. Spaces where patient } \\
\text { care is directly provided. } 3 \text {. Spaces where an } \\
\text { automatic shutoff would endanger occupant safety } \\
\text { or security. } 4 \text {. Lighting intended for continuous } \\
\text { operation. } 5 \text {. Shop and laboratory classrooms. }\end{array}$ \\
\hline
\end{tabular}




\begin{tabular}{|c|c|c|c|c|c|c|}
\hline Measure & $\begin{array}{l}\text { Std } \\
90.1- \\
2013 \\
\text { Section } \\
\text { Number }\end{array}$ & $\begin{array}{l}\text { Std 90.1-2013 } \\
\text { Section Title }\end{array}$ & Std 90.1-2013 Requirement & $\begin{array}{l}2015 \text { IECC } \\
\text { Section } \\
\text { Number }\end{array}$ & $\begin{array}{l}2015 \text { IECC } \\
\text { Section Title }\end{array}$ & 2015 IECC Requirement \\
\hline $\begin{array}{c}\text { Timer-based } \\
\text { interior } \\
\text { lighting } \\
\text { controls }\end{array}$ & NA & NA & NA & C405.2.2.1 & $\begin{array}{l}\text { Time switch } \\
\text { control } \\
\text { function. }\end{array}$ & $\begin{array}{l}\text { Each space provided with time switch controls shall } \\
\text { also be provided with a manual control for light } \\
\text { reduction in accordance with Section C405.2.2.2. } \\
\text { Time switch controls shall include an override } \\
\text { switching device that complies with the following: } \\
\text { 1. Have a minimum } 7 \text {-day clock. } 2 \text {. Be capable of } \\
\text { being set for seven different day types per week. } 3 \text {. } \\
\text { Incorporate an automatic holiday "shutoff" feature, } \\
\text { which turns off all controlled lighting loads for at } \\
\text { least } 24 \text { hours and then resumes normally } \\
\text { scheduled operations. } 4 \text {. Have program backup } \\
\text { capabilities, which prevent the loss of program and } \\
\text { time settings for at least } 10 \text { hours, if power is } \\
\text { interrupted. } 5 \text {. Include an override switch that } \\
\text { complies with the following: } 5.1 \text {. The override } \\
\text { switch shall be a manual control. } 5.2 \text {. The override } \\
\text { switch, when initiated, shall permit the controlled } \\
\text { lighting to remain on for not more than } 2 \text { hours. } \\
5.3 \text {. Any individual override switch shall control the } \\
\text { lighting for an area not larger than } 5,000 \text { square } \\
\left.\text { feet (465 } \mathrm{m}^{2}\right) \text {. Exceptions: } 1 \text {. Within malls, arcades, } \\
\text { auditoriums, single-tenant retail spaces, industrial } \\
\text { facilities and arenas: } 1.1 \text {. The time limit shall be } \\
\text { permitted to be greater than } 2 \text { hours, provided that } \\
\text { the override switch is a captive key device. } 1.2 \text {. The } \\
\text { area controlled by the override switch is permitted } \\
\left.\text { to be greater than } 5,000 \text { square feet (465 } \mathrm{m}^{2}\right) \text {, but } \\
\text { shall not be greater than } 20,000 \text { square feet }(1860 \\
\left.m^{2}\right) .2 \text {. Where provided with manual control, the } \\
\text { following areas are not required to have light } \\
\text { reduction control: } 2.1 . \text { Spaces that have only one } \\
\text { luminaire with a rated power of less than } 100 \text { watts. } \\
2.2 . \text { Spaces that use less than } 0.6 \text { watts per square } \\
\left.\text { foot (6.5 } \mathrm{W} / \mathrm{m}^{2}\right) .2 .3 \text {. Corridors, equipment rooms, } \\
\text { public lobbies, electrical or mechanical rooms. }\end{array}$ \\
\hline
\end{tabular}




\begin{tabular}{|c|c|c|c|c|c|c|c|}
\hline & Measure & $\begin{array}{l}\text { Std } \\
90.1- \\
2013 \\
\text { Section } \\
\text { Number }\end{array}$ & $\begin{array}{l}\text { Std 90.1-2013 } \\
\text { Section Title }\end{array}$ & Std 90.1-2013 Requirement & $\begin{array}{l}2015 \text { IECC } \\
\text { Section } \\
\text { Number }\end{array}$ & $\begin{array}{l}2015 \text { IECC } \\
\text { Section Title }\end{array}$ & 2015 IECC Requirement \\
\hline 44 & $\begin{array}{c}\text { Variable-flow } \\
\text { hydronic } \\
\text { system } \\
\text { controls }\end{array}$ & 6.5 .4 .2 & $\begin{array}{l}\text { Hydronic } \\
\text { Variable-Flow } \\
\text { Systems }\end{array}$ & $\begin{array}{l}\text { HVAC pumping systems having a total pump } \\
\text { system power exceeding } 10 \text { hp that include } \\
\text { control valves designed to modulate or step } \\
\text { open and close as a function of load shall be } \\
\text { designed for variable fluid flow and shall be } \\
\text { capable of reducing pump flow rates to } 50 \% \\
\text { or less of the design flow rate. Individual } \\
\text { chilled-water pumps serving variable-flow } \\
\text { systems having motors exceeding } 5 \text { hp shall } \\
\text { have controls and/or devices (such as } \\
\text { variable-speed control) that will result in } \\
\text { pump motor demand of no more than } 30 \% \text { of } \\
\text { design wattage at } 50 \% \text { of design water flow. } \\
\text { The controls or devices shall be controlled as } \\
\text { a function of desired flow or to maintain a } \\
\text { minimum required differential pressure. } \\
\text { Differential pressure shall be measured at or } \\
\text { near the most remote heat exchanger or the } \\
\text { heat exchanger requiring the greatest } \\
\text { differential pressure. The differential pressure } \\
\text { setpoint shall be no more than } 110 \% \text { of that } \\
\text { required to achieve design flow through the } \\
\text { heat exchanger. Where differential pressure } \\
\text { control is used to comply with this section } \\
\text { and DDC systems are used, the setpoint shall } \\
\text { be reset downward based on valve positions } \\
\text { until one valve is nearly wide open. } \\
\text { Exceptions: } 1 . \text { Systems where the minimum } \\
\text { flow is less than the minimum flow required } \\
\text { by the equipment manufacturer for the } \\
\text { proper operation of equipment served by the } \\
\text { system, such as chillers, and where total } \\
\text { pump system power is } 75 \text { hp or less } 2 \text {. } \\
\text { Systems that include no more than three } \\
\text { control valves. }\end{array}$ & C403.4.2.4 & $\begin{array}{l}\text { Part-load } \\
\text { controls. }\end{array}$ & $\begin{array}{l}\text { Hydronic systems greater than or equal to } 500,000 \\
\text { Btu/h (146.5 kW) in design output capacity } \\
\text { supplying heated or chilled water to comfort } \\
\text { conditioning systems shall include controls that } \\
\text { have the capability to do all of the following: } 1 \text {. } \\
\text { Automatically reset the supply-water temperatures } \\
\text { in response to varying building heating and cooling } \\
\text { demand using coil valve position, zone return water } \\
\text { temperature, building-return water temperature or } \\
\text { outside air temperature. The temperature shall be } \\
\text { capable of being reset by not less than } 25 \text { percent } \\
\text { of the design supply-to return water temperature } \\
\text { difference. } 2 \text {. Automatically vary fluid flow for } \\
\text { hydronic systems with a combined motor capacity } \\
\text { of } 10 \text { hp (7.5 kW) or larger with three or more } \\
\text { control valves or other devices by reducing the } \\
\text { system design flow rate by not less than } 50 \text { percent } \\
\text { by designed valves that modulate or step open and } \\
\text { close, or pumps that modulate or turn on and off as } \\
\text { a function of load. } 3 \text {. Automatically vary pump flow } \\
\text { on chilled-water systems and heat rejection loops } \\
\text { serving water-cooled unitary air conditioners with a } \\
\text { combined motor capacity of } 10 \text { hp (7.5 kW) or } \\
\text { larger by reducing pump design flow by not less } \\
\text { than } 50 \text { percent, utilizing adjustable speed drives on } \\
\text { pumps, or multiple-staged pumps where not less } \\
\text { than one-half of the total pump horsepower is } \\
\text { capable of being automatically turned off. Pump } \\
\text { flow shall be controlled to maintain one control } \\
\text { valve nearly wide open or to satisfy the minimum } \\
\text { differential pressure. Exceptions: } 1 \text {. Supply-water } \\
\text { temperature reset for chilled-water systems } \\
\text { supplied by off-site district chilled water or chilled } \\
\text { water from ice storage systems. } 2 \text {. Minimum flow } \\
\text { rates other than } 50 \text { percent as required by the } \\
\text { equipment manufacturer for proper operation of } \\
\text { equipment where using flow bypass or end-of-line } \\
3 \text {-way valves. } 3 \text {. Variable pump flow on dedicated } \\
\text { equipment circulation pumps where configured in } \\
\text { primary/secondary design to provide the minimum } \\
\text { flow requirements of the equipment manufacturer } \\
\text { for proper operation of equipment. }\end{array}$ \\
\hline
\end{tabular}




\begin{tabular}{|c|c|c|c|c|c|c|c|}
\hline & Measure & $\begin{array}{l}\text { Std } \\
90.1- \\
2013 \\
\text { Section } \\
\text { Number } \\
\end{array}$ & $\begin{array}{l}\text { Std 90.1-2013 } \\
\text { Section Title }\end{array}$ & Std 90.1-2013 Requirement & $\begin{array}{l}2015 \text { IECC } \\
\text { Section } \\
\text { Number }\end{array}$ & $\begin{array}{l}2015 \text { IECC } \\
\text { Section Title }\end{array}$ & 2015 IECC Requirement \\
\hline 45 & $\begin{array}{l}\text { VAV dynamic } \\
\text { ventilation } \\
\text { optimization }\end{array}$ & 6.5 .3 .3 & $\begin{array}{l}\text { Multiple-Zone } \\
\text { VAV System } \\
\text { Ventilation } \\
\text { Optimization } \\
\text { Control }\end{array}$ & $\begin{array}{l}\text { Multiple-zone VAV systems with DDC of } \\
\text { individual zone boxes reporting to a central } \\
\text { control panel shall include means to } \\
\text { automatically reduce outdoor air intake flow } \\
\text { below design rates in response to changes in } \\
\text { system ventilation efficiency as defined by } \\
\text { Appendix A of ASHRAE Standard } 62.1 . \\
\text { Exceptions: } 1 . \text { VAV systems with zonal } \\
\text { transfer fans that recirculate air from other } \\
\text { zones without directly mixing it with outdoor } \\
\text { air, dual-duct dual-fan VAV systems, and VAV } \\
\text { systems with fan-powered terminal units } 2 . \\
\text { Systems required to have the exhaust air } \\
\text { energy recovery complying with Section } \\
6.5 .6 .13 \text {. Systems where total design exhaust } \\
\text { airflow is more than } 70 \% \text { of total design } \\
\text { outdoor air intake flow requirements. }\end{array}$ & C403.4.4.6 & $\begin{array}{l}\text { Multiple-zone } \\
\text { VAV system } \\
\text { ventilation } \\
\text { optimization } \\
\text { control. }\end{array}$ & $\begin{array}{l}\text { Multiple-zone VAV systems with DDC of individual } \\
\text { zone boxes reporting to a central control panel shall } \\
\text { have automatic controls configured to reduce } \\
\text { outdoor air intake flow below design rates in } \\
\text { response to changes in system ventilation efficiency } \\
\text { (Ev) as defined by the International Mechanical } \\
\text { Code. Exceptions: } 1 \text {. VAV systems with zonal } \\
\text { transfer fans that recirculate air from other zones } \\
\text { without directly mixing it with outdoor air, dual- } \\
\text { duct dual-fan VAV systems, and VAV systems with } \\
\text { fan-powered terminal units. } 2 \text {. Systems having } \\
\text { exhaust air energy recovery complying with Section } \\
\text { C403.2.7. 3. Systems where total design exhaust } \\
\text { airflow is more than } 70 \text { percent of total design } \\
\text { outdoor air intake flow requirements. }\end{array}$ \\
\hline 46 & $\begin{array}{l}\text { Vestibule } \\
\text { heating } \\
\text { controls }\end{array}$ & 6.4 .3 .9 & $\begin{array}{l}\text { Heating in } \\
\text { Vestibules }\end{array}$ & $\begin{array}{l}\text { Heating for vestibules, in accordance with } \\
\text { Section 5.4.3.4, and air curtains shall include } \\
\text { automatic controls configured to shut off the } \\
\text { heating system when outdoor air } \\
\text { temperatures are above } 45^{\circ} \mathrm{F} \text {. Vestibule } \\
\text { heating systems shall also be controlled by a } \\
\text { thermostat in the vestibule with a setpoint } \\
\text { limited to a maximum of } 60^{\circ} \mathrm{F} \text {. Exception: } \\
\text { Vestibules with no heating system or that are } \\
\text { tempered with transfer air that would } \\
\text { otherwise be exhausted. }\end{array}$ & NA & NA & NA \\
\hline 47 & $\begin{array}{l}\text { Walkin cooler } \\
\text { and freezer } \\
\text { controls }\end{array}$ & 6.4 .5 & $\begin{array}{l}\text { Walkin Coolers } \\
\text { and Freezers }\end{array}$ & $\begin{array}{l}\text { Site-assembled or site-constructed walkin } \\
\text { coolers and freezers shall conform to the } \\
\text { following requirements: j. Antisweat heater } \\
\text { controls shall reduce the energy use of the } \\
\text { antisweat heater as a function of the relative } \\
\text { humidity in the air outside the door or to the } \\
\text { condensation on the inner glass pane. I. All } \\
\text { walkin freezers shall incorporate } \\
\text { temperature-based defrost termination } \\
\text { control with a time limit default. The defrost } \\
\text { cycle shall terminate first on an upper } \\
\text { temperature limit breach and second upon a } \\
\text { time limit breach. Exception: Walkin coolers }\end{array}$ & $\begin{array}{l}\text { C403.2.15 and } \\
\text { C403.2.16 }\end{array}$ & $\begin{array}{l}\text { Walkin coolers, } \\
\text { walkin } \\
\text { freezers, } \\
\text { refrigerated } \\
\text { warehouse } \\
\text { coolers and } \\
\text { refrigerated } \\
\text { warehouse } \\
\text { freezers and } \\
\text { Walkin coolers } \\
\text { and walkin } \\
\text { freezers }\end{array}$ & An entire page of requirements - not copied here. \\
\hline
\end{tabular}




\begin{tabular}{|c|c|c|c|c|c|c|c|}
\hline & Measure & \multirow[t]{2}{*}{$\begin{array}{l}\text { Std } \\
90.1- \\
2013 \\
\text { Section } \\
\text { Number } \\
\end{array}$} & \multirow[t]{2}{*}{$\begin{array}{l}\text { Std 90.1-2013 } \\
\text { Section Title }\end{array}$} & \multirow{2}{*}{$\begin{array}{l}\text { Std 90.1-2013 Requirement } \\
\text { and walkin freezers combined in a single } \\
\text { enclosure greater than } 3000 \mathrm{ft}^{2} \text {. }\end{array}$} & \multirow[t]{2}{*}{$\begin{array}{l}2015 \text { IECC } \\
\text { Section } \\
\text { Number }\end{array}$} & \multirow[t]{2}{*}{$\begin{array}{l}2015 \text { IECC } \\
\text { Section Title }\end{array}$} & \multirow[t]{2}{*}{2015 IECC Requirement } \\
\hline & & & & & & & \\
\hline 48 & $\begin{array}{l}\text { WLHP loop } \\
\text { flow controls }\end{array}$ & 6.5 .4 .5 .2 & [No Title] & $\begin{array}{l}\text { Hydronic heat pumps and water-cooled } \\
\text { unitary air conditioners having a total pump } \\
\text { system power exceeding } 5 \text { hp shall have } \\
\text { controls and/or devices (such as variable- } \\
\text { speed control) that will result in pump motor } \\
\text { demand of no more than } 30 \% \text { of design } \\
\text { wattage at } 50 \% \text { of design water flow. }\end{array}$ & C403.4.2.3.3 & $\begin{array}{l}\text { Two-position } \\
\text { valve. }\end{array}$ & $\begin{array}{l}\text { Each hydronic heat pump on the hydronic system } \\
\text { having a total pump system power exceeding } 10 \mathrm{hp} \\
(7.5 \mathrm{~kW}) \text { shall have a two-position valve. }\end{array}$ \\
\hline
\end{tabular}




\begin{tabular}{|c|c|c|c|c|c|c|c|}
\hline & Measure & $\begin{array}{l}\text { Std } \\
90.1- \\
2013 \\
\text { Section } \\
\text { Number }\end{array}$ & $\begin{array}{l}\text { Std 90.1-2013 } \\
\text { Section Title }\end{array}$ & Std 90.1-2013 Requirement & $\begin{array}{l}2015 \text { IECC } \\
\text { Section } \\
\text { Number }\end{array}$ & $\begin{array}{l}2015 \text { IECC } \\
\text { Section Title }\end{array}$ & 2015 IECC Requirement \\
\hline 49 & $\begin{array}{l}\text { WLHP loop } \\
\text { heat rejection } \\
\text { controls }\end{array}$ & 6.5 .2 .2 .3 & $\begin{array}{l}\text { Hydronic (Water } \\
\text { Loop) Heat } \\
\text { Pump System }\end{array}$ & $\begin{array}{l}\text { Hydronic heat pumps connected to a } \\
\text { common heat pump water loop with central } \\
\text { devices for heat rejection (e.g., cooling tower) } \\
\text { and heat addition (e.g., boiler) shall have the } \\
\text { following: a. Controls that are capable of } \\
\text { providing a heat-pump water supply } \\
\text { temperature dead band of at least } 20^{\circ} \mathrm{F} \\
\text { between initiation of heat rejection and heat } \\
\text { addition by the central devices (e.g., tower } \\
\text { and boiler). b. For Climate zones } 3 \text { through } 8 \text {, } \\
\text { if a closed-circuit tower (fluid cooler) is used, } \\
\text { either an automatic valve shall be installed to } \\
\text { bypass all but a minimal flow of water around } \\
\text { the tower (for freeze protection) or low- } \\
\text { leakage positive closure dampers shall be } \\
\text { provided. If an open-circuit tower is used } \\
\text { directly in the heat-pump loop, an automatic } \\
\text { valve shall be installed to bypass all heat- } \\
\text { pump water flow around the tower. If an } \\
\text { open-circuit tower is used in conjunction with } \\
\text { a separate heat exchanger to isolate the } \\
\text { tower from the heat-pump loop, then heat } \\
\text { loss shall be controlled by shutting down the } \\
\text { circulation pump on the cooling tower loop. } \\
\text { Exception: Where a system loop temperature } \\
\text { optimization controller is used to determine } \\
\text { the most efficient operating temperature } \\
\text { based on real-time conditions of demand and } \\
\text { capacity, dead bands of less than } 20^{\circ} \mathrm{F} \text { shall be } \\
\text { allowed. }\end{array}$ & $\begin{array}{l}\text { C403.4.2.3.2.1, } \\
\text { C403.4.2.3.2.2 }\end{array}$ & $\begin{array}{l}\text { Climate zones } \\
3 \text { and } 4, \\
\text { Climate zones } \\
5 \text { through } 8 .\end{array}$ & $\begin{array}{l}\text { For Climate zones } 3 \text { and } 4: 1 \text {. Where a closed-circuit } \\
\text { cooling tower is used directly in the heat pump } \\
\text { loop, either an automatic valve shall be installed to } \\
\text { bypass all but a minimal flow of water around the } \\
\text { tower, or lower leakage positive closure dampers } \\
\text { shall be provided. } 2 \text {. Where an open-circuit tower is } \\
\text { used directly in the heat pump loop, an automatic } \\
\text { valve shall be installed to bypass all heat pump } \\
\text { water flow around the tower. } 3 \text {. Where an open- or } \\
\text { closed-circuit cooling tower is used in conjunction } \\
\text { with a separate heat exchanger to isolate the } \\
\text { cooling tower from the heat pump loop, then heat } \\
\text { loss shall be controlled by shutting down the } \\
\text { circulation pump on the cooling tower loop. } \\
\text { For Climate zones } 5 \text { through } 8 \text {, where an open- or } \\
\text { closed-circuit cooling tower is used, a separate heat } \\
\text { exchanger shall be provided to isolate the cooling } \\
\text { tower from the heat pump loop, and heat loss shall } \\
\text { be controlled by shutting down the circulation } \\
\text { pump on the cooling tower loop and providing an } \\
\text { automatic valve to stop the flow of fluid. }\end{array}$ \\
\hline
\end{tabular}




\begin{tabular}{|c|c|c|c|c|c|c|c|}
\hline & Measure & $\begin{array}{l}\text { Std } \\
90.1- \\
2013 \\
\text { Section } \\
\text { Number }\end{array}$ & $\begin{array}{l}\text { Std } 90.1-2013 \\
\text { Section Title }\end{array}$ & Std 90.1-2013 Requirement & $\begin{array}{l}2015 \text { IECC } \\
\text { Section } \\
\text { Number }\end{array}$ & $\begin{array}{l}2015 \text { IECC } \\
\text { Section Title }\end{array}$ & 2015 IECC Requirement \\
\hline 50 & $\begin{array}{l}\text { WLHP loop } \\
\text { temperature } \\
\text { deadband } \\
\text { controls }\end{array}$ & $6.5 \cdot 2 \cdot 2.3$ & $\begin{array}{l}\text { Hydronic (Water } \\
\text { Loop) Heat } \\
\text { Pump System }\end{array}$ & $\begin{array}{l}\text { Hydronic heat pumps connected to a } \\
\text { common heat pump water loop with central } \\
\text { devices for heat rejection (e.g., cooling tower) } \\
\text { and heat addition (e.g., boiler) shall have the } \\
\text { following: a. Controls that are capable of } \\
\text { providing a heat-pump water supply } \\
\text { temperature dead band of at least } 20^{\circ} \mathrm{F} \\
\text { between initiation of heat rejection and heat } \\
\text { addition by the central devices (e.g., tower } \\
\text { and boiler). b. For Climate zones } 3 \text { through } 8 \text {, } \\
\text { if a closed-circuit tower (fluid cooler) is used, } \\
\text { either an automatic valve shall be installed to } \\
\text { bypass all but a minimal flow of water around } \\
\text { the tower (for freeze protection) or low- } \\
\text { leakage positive closure dampers shall be } \\
\text { provided. If an open-circuit tower is used } \\
\text { directly in the heat-pump loop, an automatic } \\
\text { valve shall be installed to bypass all heat- } \\
\text { pump water flow around the tower. If an } \\
\text { open-circuit tower is used in conjunction with } \\
\text { a separate heat exchanger to isolate the } \\
\text { tower from the heat-pump loop, then heat } \\
\text { loss shall be controlled by shutting down the } \\
\text { circulation pump on the cooling tower loop. } \\
\text { Exception: Where a system loop temperature } \\
\text { optimization controller is used to determine } \\
\text { the most efficient operating temperature } \\
\text { based on real-time conditions of demand and } \\
\text { capacity, dead bands of less than } 20^{\circ} \mathrm{F} \text { shall be } \\
\text { allowed. }\end{array}$ & C403.4.2.3.1 & $\begin{array}{l}\text { Temperature } \\
\text { dead band. }\end{array}$ & $\begin{array}{l}\text { Hydronic heat pumps connected to a common heat } \\
\text { pump water loop with central devices for heat } \\
\text { rejection and heat addition shall have controls that } \\
\text { are capable of providing a heat pump water supply } \\
\text { temperature dead band of not less than } 20^{\circ} \mathrm{F}\left(11^{\circ} \mathrm{C}\right) \\
\text { between initiation of heat rejection and heat } \\
\text { addition by the central devices. Exception: Where a } \\
\text { system loop temperature optimization controller is } \\
\text { installed and can determine the most efficient } \\
\text { operating temperature based on real-time } \\
\text { conditions of demand and capacity, dead bands of } \\
\text { less than } 20^{\circ} \mathrm{F}\left(11^{\circ} \mathrm{C}\right) \text { shall be permitted. }\end{array}$ \\
\hline
\end{tabular}




\begin{tabular}{|c|c|c|c|c|c|c|c|}
\hline & Measure & $\begin{array}{l}\text { Std } \\
90.1- \\
2013 \\
\text { Section } \\
\text { Number }\end{array}$ & $\begin{array}{l}\text { Std 90.1-2013 } \\
\text { Section Title }\end{array}$ & Std 90.1-2013 Requirement & $\begin{array}{l}2015 \text { IECC } \\
\text { Section } \\
\text { Number }\end{array}$ & $\begin{array}{l}2015 \text { IECC } \\
\text { Section Title }\end{array}$ & 2015 IECC Requirement \\
\hline 51 & $\begin{array}{l}\text { Zone isolation } \\
\text { controls }\end{array}$ & 6.4 .3 .3 .4 & Zone Isolation & $\begin{array}{l}\text { HVAC systems serving zones that are } \\
\text { intended to operate or be occupied } \\
\text { nonsimultaneously shall be divided into } \\
\text { isolation areas. Zones may be grouped into a } \\
\text { single isolation area provided it does not } \\
\text { exceed } 25,000 \mathrm{ft} 2 \text { of conditioned floor area } \\
\text { nor include more than one floor. Each } \\
\text { isolation area shall be equipped with isolation } \\
\text { devices capable of automatically shutting off } \\
\text { the supply of conditioned air and outdoor air } \\
\text { to and exhaust air from the area. Each } \\
\text { isolation area shall be controlled } \\
\text { independently by a device meeting the } \\
\text { requirements of Section } 6.4 .3 .3 .1 \text {. For central } \\
\text { systems and plants, controls and devices shall } \\
\text { be provided to allow stable system and } \\
\text { equipment operation for any length of time } \\
\text { while serving only the smallest isolation area } \\
\text { served by the system or plant. Exceptions: } \\
\text { Isolation devices and controls are not } \\
\text { required for } 1 \text {. exhaust air and outdoor air } \\
\text { connections to isolation zones when the fan } \\
\text { system to which they connect is } 5000 \mathrm{cfm} \text { and } \\
\text { smaller; } 2 \text {. exhaust airflow from a single } \\
\text { isolation zone of less than } 10 \% \text { of the design } \\
\text { airflow of the exhaust system to which it } \\
\text { connects; or } 3 \text {. zones intended to operate } \\
\text { continuously or intended to be inoperative } \\
\text { only when all other zones are inoperative. }\end{array}$ & C403.2.4.4 & Zone isolation. & $\begin{array}{l}\text { HVAC systems serving zones that are over } 25,000 \\
\text { square feet }\left(2323 \mathrm{~m}^{2}\right) \text { in floor area or that span } \\
\text { more than one floor and are designed to operate or } \\
\text { be occupied nonsimultaneously shall be divided into } \\
\text { isolation areas. Each isolation area shall be } \\
\text { equipped with isolation devices and controls } \\
\text { configured to automatically shut off the supply of } \\
\text { conditioned air and outdoor air to and exhaust air } \\
\text { from the isolation area. Each isolation area shall be } \\
\text { controlled independently by a device meeting the } \\
\text { requirements of Section C403.2.4.2.2. Central } \\
\text { systems and plants shall be provided with controls } \\
\text { and devices that will allow system and equipment } \\
\text { operation for any length of time while serving only } \\
\text { the smallest isolation area served by the system or } \\
\text { plant. Exceptions: } 1 \text {. Exhaust air and outdoor air } \\
\text { connections to isolation areas where the fan system } \\
\text { to which they connect is not greater than } 5,000 \text { cfm } \\
\text { ( } 2360 \text { L/s). } 2 \text {. Exhaust airflow from a single isolation } \\
\text { area of less than } 10 \text { percent of the design airflow of } \\
\text { the exhaust system to which it connects. 3. Isolation } \\
\text { areas intended to operate continuously or intended } \\
\text { to be inoperative only when all other isolation areas } \\
\text { in a zone are inoperative. }\end{array}$ \\
\hline
\end{tabular}


Appendix B

Commissioning Agent Interview Responses 


\section{Appendix B}

\section{Commissioning Agent Interview Responses}

\begin{tabular}{|c|c|c|c|c|c|c|c|c|c|c|c|}
\hline Organization Location & Seattle, WA & $\begin{array}{c}\text { Sacramento } \\
\text { CA }\end{array}$ & $\begin{array}{l}\text { Gainesville } \\
\text { FL }\end{array}$ & Mesa AZ & Dallas TX & Seattle WA & Toronto ON & Denver CO & $\begin{array}{l}\text { Lexington } \\
\mathrm{KY}\end{array}$ & Austin TX & Avg \\
\hline $\begin{array}{l}\text { How many buildings as } \\
\text { CXA? }\end{array}$ & 80 & 30 & 90 & $\begin{array}{l}100 \text { or } \\
\text { more }\end{array}$ & 1000 & 200 & 40 & 35 & 525 & 50 & 215 \\
\hline $\begin{array}{l}\text { Is energy code } \\
\text { compliance verification } \\
\text { included in your scope }\end{array}$ & Yes & Yes & No & No & No & Yes & No & No & No & Yes & $40 \%$ \\
\hline $\begin{array}{l}\text { Design review of lighting } \\
\text { and HVAC system for } \\
\text { compliance with energy } \\
\text { codes, }\end{array}$ & Yes & Yes & Yes & No & No & Yes & No & No & No & Yes & $50 \%$ \\
\hline $\begin{array}{l}\text { Design review of lighting } \\
\text { and HVAC controls plans } \\
\text { and specifications for } \\
\text { compliance with energy } \\
\text { codes, }\end{array}$ & Yes & Yes & Yes & No & No & Yes & No & No & No & Yes & $50 \%$ \\
\hline $\begin{array}{l}\text { Lighting and HVAC } \\
\text { controls submittal review, } \\
\text { including sequence of } \\
\text { operation, for compliance } \\
\text { with energy codes, }\end{array}$ & Yes & Yes & Yes & No & No & Yes & No & No & No & Yes & $50 \%$ \\
\hline $\begin{array}{l}\text { Functional testing of } \\
\text { building controls, } \\
\text { including verification of } \\
\text { proper implementation of } \\
\text { energy code-required } \\
\text { controls, }\end{array}$ & Yes & Yes & No & No & No & Yes & No & No & No & No & $30 \%$ \\
\hline $\begin{array}{l}\text { Controls data trend } \\
\text { analysis after occupancy } \\
\text { to verify proper } \\
\text { functioning of energy } \\
\text { code-required controls. }\end{array}$ & Yes & Yes & No & No & No & Yes & No & No & No & No & $30 \%$ \\
\hline
\end{tabular}




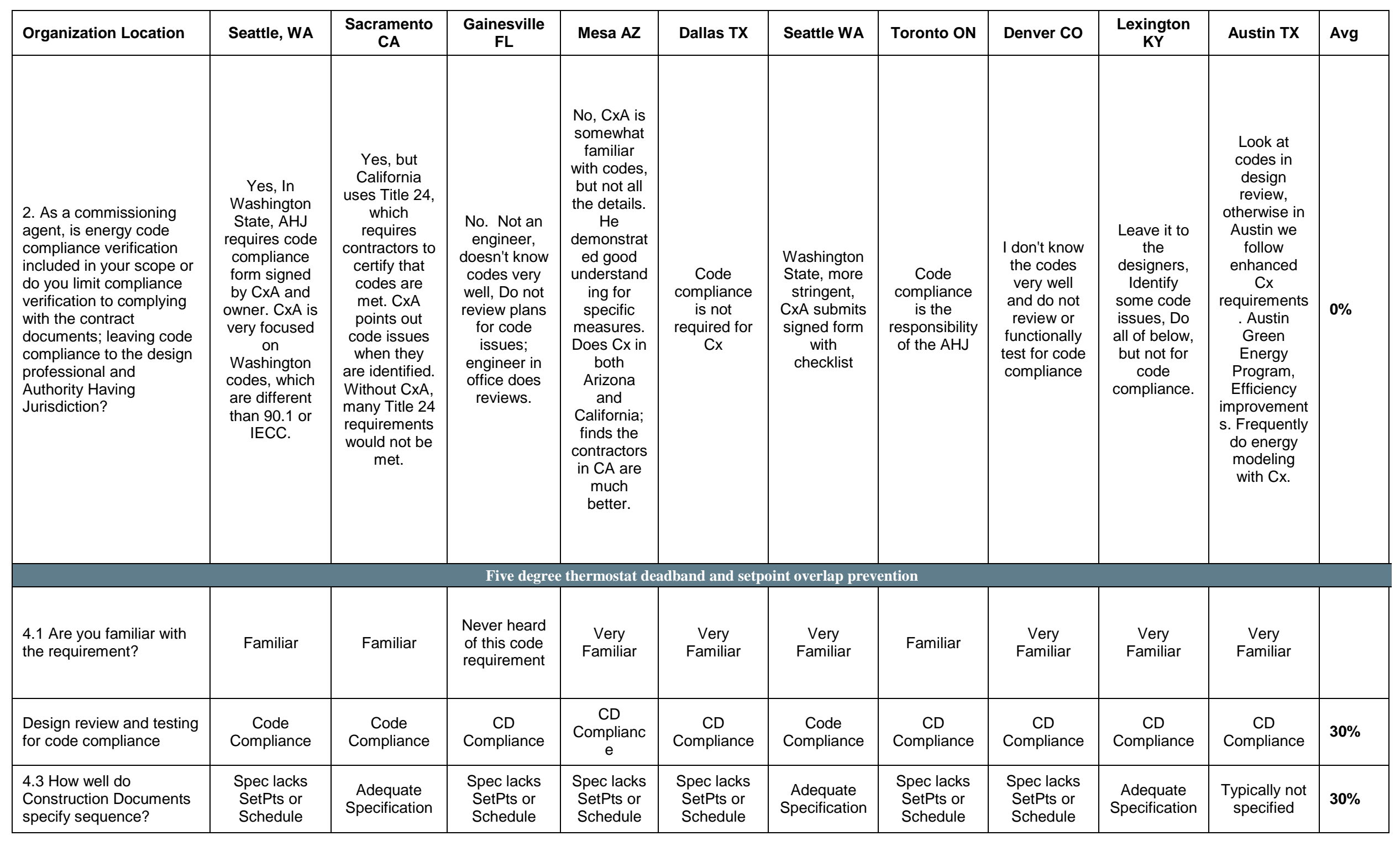




\begin{tabular}{|c|c|c|c|c|c|c|c|c|c|c|c|}
\hline Organization Location & Seattle, WA & $\begin{array}{c}\text { Sacramento } \\
\text { CA }\end{array}$ & $\begin{array}{c}\text { Gainesville } \\
\text { FL }\end{array}$ & Mesa AZ & Dallas TX & Seattle WA & Toronto ON & Denver CO & $\begin{array}{c}\text { Lexington } \\
\mathrm{KY}\end{array}$ & Austin TX & Avg \\
\hline $\begin{array}{l}\text { 4.4 What percent of the } \\
\text { time do you find the } \\
\text { measure meeting code or } \\
\text { requirements on the 1st } \\
\text { pass of functional } \\
\text { testing? }\end{array}$ & 50 & 45 & 90 & 30 & 10 & 75 & 50 & 30 & 30 & 50 & $46 \%$ \\
\hline $\begin{array}{l}4.5 \text { What percent of the } \\
\text { time do you find the } \\
\text { measure meeting code or } \\
\text { requirements at the } \\
\text { completion of Cx? }\end{array}$ & 55 & 50 & 90 & 40 & 30 & 80 & 60 & 40 & 40 & 70 & $56 \%$ \\
\hline $\begin{array}{l}4.8 \text { If the measure is not } \\
\text { operating as required by } \\
\text { code, what percentage of } \\
\text { buildings have necessary } \\
\text { hardware \& software to } \\
\text { meet code? }\end{array}$ & 100 & 100 & 90 & 90 & 75 & 100 & 90 & 100 & $\mathrm{~N} / \mathrm{A}$ & 90 & $93 \%$ \\
\hline $\begin{array}{l}\text { 4.6 What are the common } \\
\text { deficiencies associated } \\
\text { with this measure? }\end{array}$ & Programming & Setpts & $\begin{array}{c}\text { Always a } 6 \mathrm{~F} \\
\text { deadband in } \\
\text { Florida. Labs } \\
\text { with tight } \\
\text { deadbands } \\
\text { don't comply }\end{array}$ & $\begin{array}{l}\text { Not always } \\
\text { 5F, Put in } \\
\text { typical } \\
\text { value, } \\
\text { don't use } \\
\text { spec }\end{array}$ & $\begin{array}{l}\text { Poor } \\
\text { programmin } \\
\text { g, tstats not } \\
\text { connected }\end{array}$ & $\begin{array}{l}\text { Sometimes } \\
4 \mathrm{~F} \text {, Code is } \\
6 \mathrm{~F} \text {, owner } \\
\text { input }\end{array}$ & $\begin{array}{c}\text { Not always } 5 \\
\text { degrees }\end{array}$ & $\begin{array}{c}\text { Not always } 5 \\
\text { degrees }\end{array}$ & $\begin{array}{l}\text { Improper } \\
\text { setup of } \\
\text { controls, } \\
\text { poor } \\
\text { submittal } \\
\text { prep }\end{array}$ & $\begin{array}{c}\text { Temp setpts } \\
\text { not } 5 \mathrm{~F}\end{array}$ & \\
\hline $\begin{array}{l}4.7 \text { What can be done to } \\
\text { help ensure this measure } \\
\text { is correctly implemented? }\end{array}$ & $\begin{array}{l}\text { Get in } \\
\text { sequence }\end{array}$ & $\begin{array}{l}\text { Contractor is } \\
\text { responsible } \\
\text { to meet code }\end{array}$ & & $\begin{array}{l}\text { Clarificatio } \\
\mathrm{n} \text { in } \\
\text { design, } \\
\text { specify } \\
\text { exact } \\
\text { values }\end{array}$ & $\begin{array}{c}\text { Proper } \\
\text { installation \& } \\
\text { Cx, Proper } \\
\text { design }\end{array}$ & $\begin{array}{l}\text { Show owner } \\
\text { savings from } \\
\text { setpts }\end{array}$ & $\begin{array}{l}\text { Tighter spec } \\
\text { from MEP, } \\
\text { Better } \\
\text { education in } \\
\text { industry on } \\
\text { codes }\end{array}$ & $\begin{array}{l}\text { Not always } 5 \\
\text { degrees }\end{array}$ & $\begin{array}{l}\text { Meeting with } \\
\text { controls } \\
\text { contractor }\end{array}$ & $\begin{array}{l}\text { Decision } \\
\text { maker } \\
\text { dominates }\end{array}$ & \\
\hline \multicolumn{12}{|c|}{ Occupant-based interior lighting controls } \\
\hline $\begin{array}{l}5.1 \text { Are you familiar with } \\
\text { the requirement? }\end{array}$ & Familiar & Very Familiar & $\begin{array}{l}\text { Never Heard } \\
\text { of It }\end{array}$ & $\begin{array}{l}\text { Very } \\
\text { Familiar }\end{array}$ & $\begin{array}{c}\text { Very } \\
\text { Familiar }\end{array}$ & $\begin{array}{c}\text { Very } \\
\text { Familiar }\end{array}$ & $\begin{array}{l}\text { Somewhat } \\
\text { Familiar }\end{array}$ & $\begin{array}{l}\text { Very } \\
\text { Familiar }\end{array}$ & $\begin{array}{c}\text { Very } \\
\text { Familiar }\end{array}$ & $\begin{array}{c}\text { Very } \\
\text { Familiar }\end{array}$ & \\
\hline
\end{tabular}




\begin{tabular}{|c|c|c|c|c|c|c|c|c|c|c|c|}
\hline Organization Location & Seattle, WA & $\begin{array}{c}\text { Sacramento } \\
\text { CA }\end{array}$ & $\begin{array}{l}\text { Gainesville } \\
\text { FL }\end{array}$ & Mesa AZ & Dallas TX & Seattle WA & Toronto ON & Denver Co & $\begin{array}{l}\text { Lexington } \\
\mathrm{KY}\end{array}$ & Austin TX & Avg \\
\hline $\begin{array}{l}\text { Design review and testing } \\
\text { for code compliance }\end{array}$ & $\begin{array}{l}\text { Code } \\
\text { Compliance }\end{array}$ & $\begin{array}{l}\text { Code } \\
\text { Compliance }\end{array}$ & $\begin{array}{l}\mathrm{CD} \\
\text { Compliance }\end{array}$ & $\begin{array}{l}\text { CD } \\
\text { Complianc } \\
\text { e }\end{array}$ & $\begin{array}{c}\mathrm{CD} \\
\text { Compliance }\end{array}$ & $\begin{array}{c}\text { Code } \\
\text { Compliance }\end{array}$ & $\begin{array}{c}\mathrm{CD} \\
\text { Compliance }\end{array}$ & $\begin{array}{l}\text { Code } \\
\text { Compliance }\end{array}$ & $\begin{array}{c}\mathrm{CD} \\
\text { Compliance }\end{array}$ & $\begin{array}{c}\mathrm{CD} \\
\text { Compliance }\end{array}$ & $40 \%$ \\
\hline $\begin{array}{l}5.3 \text { How well do } \\
\text { Construction Documents } \\
\text { specify sequence? }\end{array}$ & $\begin{array}{l}\text { Spec Lacks } \\
\text { SetPts or } \\
\text { Schedule }\end{array}$ & $\begin{array}{l}\text { Adequate } \\
\text { Specification }\end{array}$ & $\begin{array}{l}\text { Adequate } \\
\text { Specification }\end{array}$ & $\begin{array}{c}\text { Spec } \\
\text { Lacks } \\
\text { SetPts or } \\
\text { Schedule }\end{array}$ & $\begin{array}{l}\text { Spec Lacks } \\
\text { SetPts or } \\
\text { Schedule }\end{array}$ & $\begin{array}{l}\text { Excellent } \\
\text { Spec With } \\
\text { Diagram }\end{array}$ & $\begin{array}{l}\text { Typically Not } \\
\text { Specified }\end{array}$ & $\begin{array}{l}\text { Spec Lacks } \\
\text { SetPts or } \\
\text { Schedule }\end{array}$ & $\begin{array}{l}\text { Spec Lacks } \\
\text { SetPts or } \\
\text { Schedule }\end{array}$ & $\begin{array}{l}\text { Typically Not } \\
\text { Specified }\end{array}$ & $20 \%$ \\
\hline $\begin{array}{l}5.4 \text { What percent of the } \\
\text { time do you find the } \\
\text { measure meeting code or } \\
\text { requirements on the 1st } \\
\text { pass of functional } \\
\text { testing? }\end{array}$ & 80 & 75 & 70 & 25 & 10 & 80 & NA & 50 & 40 & 10 & $49 \%$ \\
\hline $\begin{array}{l}5.5 \text { What percent of the } \\
\text { time do you find the } \\
\text { measure meeting code or } \\
\text { requirements at the } \\
\text { completion of } C x \text { ? }\end{array}$ & 100 & 90 & 95 & 95 & 80 & 95 & NA & 95 & 98 & 10 & $84 \%$ \\
\hline $\begin{array}{l}5.8 \text { If the measure is not } \\
\text { operating as required by } \\
\text { code, what percentage of } \\
\text { buildings have necessary } \\
\text { hardware \& software to } \\
\text { meet code? }\end{array}$ & 90 & 100 & $\mathrm{~N} / \mathrm{A}$ & 100 & 75 & 100 & N/A & 100 & $\mathrm{~N} / \mathrm{A}$ & 40 & $86 \%$ \\
\hline $\begin{array}{l}5.6 \text { What are the common } \\
\text { deficiencies associated } \\
\text { with this measure? }\end{array}$ & $\begin{array}{l}\text { Not } \\
\text { programmed } \\
\text { correctly, } \\
\text { Occupancy vs } \\
\text { vacancy }\end{array}$ & $\begin{array}{l}\text { Programmers } \\
\text { don't } \\
\text { understand } \\
\text { new code }\end{array}$ & & $\begin{array}{l}\text { Lighting } \\
\text { controls } \\
\text { poorly } \\
\text { specified, } \\
\text { hardly ever } \\
\text { properly } \\
\text { programm } \\
\text { ed }\end{array}$ & $\begin{array}{c}\text { Lack of } \\
\text { proper } \\
\text { installation \& } \\
\text { location }\end{array}$ & $\begin{array}{l}\text { Coverage of } \\
\text { occupancy } \\
\text { sensor, } \\
\text { sensitivity, } \\
\text { programmin } \\
\mathrm{g}\end{array}$ & NA & $\begin{array}{l}\text { Programmin } \\
\text { g setpts, } \\
\text { sensor type, } \\
\text { and location } \\
\text { is poorly } \\
\text { specified. } \\
\text { Different } \\
\text { hardware } \\
\text { often } \\
\text { required to } \\
\text { meet spec }\end{array}$ & $\begin{array}{l}\text { Not shutting } \\
\text { off, } \\
\text { Programmin } \\
\text { g of Occ } \\
\text { sensors, } \\
\text { Improper } \\
\text { specification } \\
\text { of lighting } \\
\text { controls, } \\
\text { Product } \\
\text { integration }\end{array}$ & $\begin{array}{c}\text { Use } \\
\text { occupancy } \\
\text { vs vacancy, }\end{array}$ & \\
\hline
\end{tabular}




\begin{tabular}{|c|c|c|c|c|c|c|c|c|c|c|c|}
\hline Organization Location & Seattle, WA & $\begin{array}{c}\text { Sacramento } \\
\text { CA }\end{array}$ & $\begin{array}{l}\text { Gainesville } \\
\text { FL }\end{array}$ & Mesa AZ & Dallas TX & Seattle WA & Toronto ON & Denver CO & $\begin{array}{l}\text { Lexington } \\
\mathrm{KY}\end{array}$ & Austin TX & Avg \\
\hline $\begin{array}{l}5.7 \text { What can be done to } \\
\text { help ensure this measure } \\
\text { is correctly implemented? }\end{array}$ & $\begin{array}{l}\text { Getting info to } \\
\text { installing } \\
\text { contractor, } \\
\text { Not enough } \\
\text { detail in specs }\end{array}$ & & $\begin{array}{c}\text { Well } \\
\text { specified, } \\
\text { installers lack } \\
\text { understandin } \\
\text { g }\end{array}$ & $\begin{array}{l}\text { Written } \\
\text { sequence, } \\
\text { timeouts, } \\
\text { manual on, } \\
\text { zoning }\end{array}$ & $\begin{array}{l}\text { Design, } \\
\text { installed, } \\
\text { and Cx. }\end{array}$ & $\begin{array}{c}\text { Well } \\
\text { Specified, } \\
\text { plans, } \\
\text { lighting } \\
\text { sequence, } \\
\text { lighting } \\
\text { design, } \\
\text { space matrix }\end{array}$ & Education & $\begin{array}{l}\text { Good control } \\
\text { spec with } \\
\text { setpts and } \\
\text { schedules, } \\
\text { Contractor } \\
\text { need to } \\
\text { respond to } \\
\text { issues }\end{array}$ & $\begin{array}{l}\text { Vendor } \\
\text { coord in } \\
\text { design, pre- } \\
\text { installation } \\
\text { meetings }\end{array}$ & $\begin{array}{l}\text { Education, } \\
\text { Mfg not offer } \\
\text { occ, Better } \\
\text { specification, } \\
\text { No detail in } \\
\text { spec }\end{array}$ & \\
\hline \multicolumn{12}{|c|}{ Integrated Economizer with high limit controls } \\
\hline $\begin{array}{l}6.1 \text { Are you familiar with } \\
\text { the requirement? }\end{array}$ & Very Familiar & Very Familiar & $\begin{array}{l}\text { Somewhat } \\
\text { Familiar }\end{array}$ & $\begin{array}{l}\text { Very } \\
\text { Familiar }\end{array}$ & $\begin{array}{l}\text { Very } \\
\text { Familiar }\end{array}$ & $\begin{array}{l}\text { Very } \\
\text { Familiar }\end{array}$ & Familiar & $\begin{array}{l}\text { Very } \\
\text { Familiar }\end{array}$ & $\begin{array}{c}\text { Very } \\
\text { Familiar }\end{array}$ & $\begin{array}{l}\text { Very } \\
\text { Familiar }\end{array}$ & \\
\hline $\begin{array}{l}\text { Design review and testing } \\
\text { for code compliance }\end{array}$ & $\begin{array}{c}\text { Code } \\
\text { Compliance }\end{array}$ & $\begin{array}{l}\text { Code } \\
\text { Compliance }\end{array}$ & $\begin{array}{c}\mathrm{CD} \\
\text { Compliance }\end{array}$ & $\begin{array}{c}\text { CD } \\
\text { Complianc } \\
\mathrm{e}\end{array}$ & $\begin{array}{c}\mathrm{CD} \\
\text { Compliance }\end{array}$ & $\begin{array}{c}\text { Code } \\
\text { Compliance }\end{array}$ & $\begin{array}{c}\mathrm{CD} \\
\text { Compliance }\end{array}$ & $\begin{array}{c}\mathrm{CD} \\
\text { Compliance }\end{array}$ & $\begin{array}{c}\mathrm{CD} \\
\text { Compliance }\end{array}$ & $\begin{array}{l}\text { Code } \\
\text { Compliance }\end{array}$ & $40 \%$ \\
\hline $\begin{array}{l}6.4 \text { What percent of the } \\
\text { time do you find the } \\
\text { measure meeting code or } \\
\text { requirements on the } 1 \mathrm{st} \\
\text { pass of functional } \\
\text { testing? }\end{array}$ & 60 & 60 & 50 & 50 & 5 & 60 & 55 & 70 & 30 & 20 & $46 \%$ \\
\hline $\begin{array}{l}6.5 \text { What percent of the } \\
\text { time do you find the } \\
\text { measure meeting code or } \\
\text { requirements at the } \\
\text { completion of Cx? }\end{array}$ & 75 & 75 & 75 & 75 & 60 & 80 & 75 & 80 & 80 & 50 & $73 \%$ \\
\hline $\begin{array}{l}6.8 \text { If the measure is not } \\
\text { operating as required by } \\
\text { code, what percentage of } \\
\text { buildings have necessary } \\
\text { hardware \& software to } \\
\text { meet code? }\end{array}$ & 100 & N/A & N/A & 100 & 75 & 100 & 100 & 100 & N/A & 90 & $95 \%$ \\
\hline
\end{tabular}




\begin{tabular}{|c|c|c|c|c|c|c|c|c|c|c|c|}
\hline Organization Location & Seattle, WA & $\begin{array}{c}\text { Sacramento } \\
\text { CA }\end{array}$ & $\begin{array}{c}\text { Gainesville } \\
\text { FL }\end{array}$ & Mesa AZ & Dallas TX & Seattle WA & Toronto ON & Denver Co & $\begin{array}{l}\text { Lexington } \\
\mathrm{KY}\end{array}$ & Austin TX & Avg \\
\hline $\begin{array}{l}\text { 6.6 What are the common } \\
\text { deficiencies associated } \\
\text { with this measure? }\end{array}$ & $\begin{array}{c}\text { Initial } \\
\text { programming } \\
\text { errors, sensor } \\
\text { in wrong spot, } \\
\text { dampers not } \\
\text { right }\end{array}$ & $\begin{array}{l}\text { Getting } \\
\text { system to } \\
\text { perform with } \\
\text { software }\end{array}$ & $\begin{array}{l}\text { Programming } \\
\text { or calibration } \\
\text { of humidity } \\
\text { sensor }\end{array}$ & $\begin{array}{l}\text { Mfg } \\
\text { programmi } \\
\text { ng not } \\
\text { correct, } \\
\text { factory } \\
\text { controls }\end{array}$ & $\begin{array}{c}\text { Sensor } \\
\text { location, } \\
\text { programmin } \\
\text { g, equipment } \\
\text { not } \\
\text { connected, } \\
\text { dampers } \\
\text { jammed }\end{array}$ & $\begin{array}{c}\text { Poor } \\
\text { programmin } \\
\text { g, factory } \\
\text { controls not } \\
\text { set up, } \\
\text { sensors, } \\
\text { sequence }\end{array}$ & $\begin{array}{l}\text { Not properly } \\
\text { set up, } \\
\text { doesn't meet } \\
\text { spec }\end{array}$ & $\begin{array}{l}\text { Econo not } \\
\text { fully open } \\
\text { prior to } \\
\text { mech } \\
\text { cooling }\end{array}$ & $\begin{array}{l}\text { Improper } \\
\text { duct sizing, } \\
\text { incorrect } \\
\text { control } \\
\text { sequences, } \\
\text { factory } \\
\text { controlled }\end{array}$ & $\begin{array}{l}\text { Poor } \\
\text { sensors, } \\
\text { poor } \\
\text { sequence, } \\
\text { poor } \\
\text { dampers }\end{array}$ & \\
\hline $\begin{array}{l}6.7 \text { What can be done to } \\
\text { help ensure this measure } \\
\text { is correctly implemented? }\end{array}$ & $\begin{array}{c}\text { Conversation } \\
\text { with controls } \\
\text { tech, } \\
\text { Schedule } \\
\text { series of } \\
\text { controls } \\
\text { meetings. }\end{array}$ & & & $\begin{array}{c}\text { Functional } \\
\text { test \& work } \\
\text { with mfg, } \\
\text { Require } \\
\text { mfg } \\
\text { sequence } \\
\text { control seq } \\
\text { form mfg }\end{array}$ & $\begin{array}{l}\text { Design, } \\
\text { installation, } \\
\text { programmin } \\
\mathrm{g}, \mathrm{cx}\end{array}$ & $\begin{array}{l}\text { Investigating } \\
, \text { Cx } \\
\text { meetings }\end{array}$ & $\begin{array}{l}\text { Kickoff } \\
\text { meeting, but } \\
\text { not in detail. } \\
\text { Code } \\
\text { education }\end{array}$ & $\begin{array}{l}\text { Good control } \\
\text { sequence }\end{array}$ & $\begin{array}{l}\text { HVAC } \\
\text { design } \\
\text { review, Slect } \\
\text { equipment } \\
\text { that can } \\
\text { meet } \\
\text { requirement, }\end{array}$ & $\begin{array}{l}\text { Education, } \\
\text { MEP don't } \\
\text { know of } \\
\text { requirement. } \\
\text { Austin does } \\
\text { not mention } \\
\text { \& AHJ looks } \\
\text { the other } \\
\text { way. }\end{array}$ & \\
\hline \multicolumn{12}{|c|}{ Off-hour automatic temperature setback and system shutoff with manual override } \\
\hline $\begin{array}{l}7.1 \text { Are you familiar with } \\
\text { the requirement? }\end{array}$ & Very Familiar & Very Familiar & $\begin{array}{c}\text { Somewhat } \\
\text { Familiar }\end{array}$ & $\begin{array}{c}\text { Very } \\
\text { Familiar }\end{array}$ & $\begin{array}{c}\text { Very } \\
\text { Familiar }\end{array}$ & $\begin{array}{c}\text { Very } \\
\text { Familiar }\end{array}$ & $\begin{array}{l}\text { Somewhat } \\
\text { Familiar }\end{array}$ & $\begin{array}{c}\text { Very } \\
\text { Familiar }\end{array}$ & $\begin{array}{c}\text { Very } \\
\text { Familiar }\end{array}$ & $\begin{array}{c}\text { Very } \\
\text { Familiar }\end{array}$ & \\
\hline $\begin{array}{l}\text { Design review and testing } \\
\text { for code compliance }\end{array}$ & $\begin{array}{c}\text { Code } \\
\text { Compliance }\end{array}$ & $\begin{array}{l}\text { Code } \\
\text { Compliance }\end{array}$ & $\begin{array}{c}\mathrm{CD} \\
\text { Compliance }\end{array}$ & $\begin{array}{c}\text { General } \\
\text { Expectatio } \\
\text { ns }\end{array}$ & $\begin{array}{c}\mathrm{CD} \\
\text { Compliance }\end{array}$ & $\begin{array}{c}\text { Code } \\
\text { Compliance }\end{array}$ & $\begin{array}{c}\mathrm{CD} \\
\text { Compliance }\end{array}$ & $\begin{array}{l}\text { Code } \\
\text { Compliance }\end{array}$ & $\begin{array}{c}\mathrm{CD} \\
\text { Compliance }\end{array}$ & $\begin{array}{c}\mathrm{CD} \\
\text { Compliance }\end{array}$ & $40 \%$ \\
\hline $\begin{array}{l}7.3 \text { How well do } \\
\text { Construction Documents } \\
\text { specify sequence? }\end{array}$ & $\begin{array}{l}\text { Adequate } \\
\text { Specification }\end{array}$ & $\begin{array}{l}\text { Adequate } \\
\text { Specification }\end{array}$ & $\begin{array}{l}\text { Adequate } \\
\text { Specification }\end{array}$ & $\begin{array}{l}\text { Adequate } \\
\text { Specificati } \\
\text { on }\end{array}$ & $\begin{array}{l}\text { Spec Lacks } \\
\text { SetPts or } \\
\text { Schedule }\end{array}$ & $\begin{array}{l}\text { Spec Lacks } \\
\text { SetPts or } \\
\text { Schedule }\end{array}$ & $\begin{array}{l}\text { Adequate } \\
\text { Specification }\end{array}$ & $\begin{array}{l}\text { Adequate } \\
\text { Specification }\end{array}$ & $\begin{array}{l}\text { Adequate } \\
\text { Specification }\end{array}$ & $\begin{array}{l}\text { Adequate } \\
\text { Specification }\end{array}$ & $80 \%$ \\
\hline $\begin{array}{l}7.4 \text { What percent of the } \\
\text { time do you find the } \\
\text { measure meeting code or } \\
\text { requirements on the 1st } \\
\text { pass of functional } \\
\text { testing? }\end{array}$ & 75 & 75 & 50 & 80 & 20 & 50 & 75 & 80 & 50 & 65 & $62 \%$ \\
\hline $\begin{array}{l}7.5 \text { What percent of the } \\
\text { time do you find the } \\
\text { measure meeting code or } \\
\text { requirements at the } \\
\text { completion of Cx? }\end{array}$ & 90 & 90 & 95 & 90 & 90 & 98 & 90 & 90 & 90 & 85 & $91 \%$ \\
\hline
\end{tabular}




\begin{tabular}{|c|c|c|c|c|c|c|c|c|c|c|c|}
\hline Organization Location & Seattle, WA & $\begin{array}{c}\text { Sacramento } \\
\text { CA }\end{array}$ & $\begin{array}{l}\text { Gainesville } \\
\text { FL }\end{array}$ & Mesa AZ & Dallas TX & Seattle WA & Toronto ON & Denver CO & $\begin{array}{l}\text { Lexington } \\
\mathrm{KY}\end{array}$ & Austin TX & Avg \\
\hline $\begin{array}{l}7.8 \text { If the measure is not } \\
\text { operating as required by } \\
\text { code, what percentage of } \\
\text { buildings have necessary } \\
\text { hardware \& software to } \\
\text { meet code? }\end{array}$ & 95 & & $\mathrm{~N} / \mathrm{A}$ & 100 & 90 & 100 & 100 & 100 & $\mathrm{~N} / \mathrm{A}$ & 100 & $98 \%$ \\
\hline $\begin{array}{l}7.6 \text { What are the common } \\
\text { deficiencies associated } \\
\text { with this measure? }\end{array}$ & $\begin{array}{l}\text { Unoccupied } \\
\text { schedules and } \\
\text { setpts, Push } \\
\text { buttons not } \\
\text { enabled }\end{array}$ & Programming & $\begin{array}{l}\text { Programming } \\
\text { or system } \\
\text { communicati } \\
\text { on issue }\end{array}$ & $\begin{array}{l}\text { Schedules, } \\
\text { match } \\
\text { occupant } \\
\text { sched }\end{array}$ & $\begin{array}{l}\text { sensor } \\
\text { location or } \\
\text { wrong } \\
\text { sensor, } \\
\text { programmin } \\
\text { g }\end{array}$ & $\begin{array}{c}\text { Lack of } \\
\text { programmin } \\
\mathrm{g}\end{array}$ & $\begin{array}{l}\text { Not } \\
\text { programmed } \\
\text { correctly per } \\
\text { CDs }\end{array}$ & No comment & No comment & $\begin{array}{l}\text { Tstat \& } \\
\text { sensor } \\
\text { calibration, } \\
\text { programmin } \\
\quad \mathrm{g}\end{array}$ & \\
\hline $\begin{array}{l}7.7 \text { What can be done to } \\
\text { help ensure this measure } \\
\text { is correctly implemented? }\end{array}$ & $\begin{array}{c}\text { Clear } \\
\text { communicatio } \\
\text { ns \& setpoints }\end{array}$ & & $\begin{array}{l}\text { Controls } \\
\text { review party }\end{array}$ & $\begin{array}{l}\text { Good } \\
\text { sequence, } \\
\text { meet with } \\
\text { owner }\end{array}$ & same & $\begin{array}{c}\text { Contractor } \\
\text { meets } \\
\text { design intent }\end{array}$ & see above & $\begin{array}{l}\text { Good control } \\
\text { sequences }\end{array}$ & $\begin{array}{l}\text { Functional } \\
\text { testing \& } \\
\text { O\&M testing }\end{array}$ & $\begin{array}{c}\text { Complete } \\
\text { testing, } \\
\text { better specs, }\end{array}$ & \\
\hline \multicolumn{12}{|c|}{ Limits on simultaneous heating and cooling - airside } \\
\hline $\begin{array}{l}\text { Are you familiar with the } \\
\text { requirement? }\end{array}$ & $\begin{array}{l}\text { Somewhat } \\
\text { Familiar }\end{array}$ & Familiar & $\begin{array}{l}\text { Somewhat } \\
\text { Familiar }\end{array}$ & Familiar & $\begin{array}{c}\text { Very } \\
\text { Familiar }\end{array}$ & $\begin{array}{c}\text { Very } \\
\text { Familiar }\end{array}$ & Familiar & $\begin{array}{l}\text { Somewhat } \\
\text { Familiar }\end{array}$ & $\begin{array}{l}\text { Very } \\
\text { Familiar }\end{array}$ & $\begin{array}{l}\text { Very } \\
\text { Familiar }\end{array}$ & \\
\hline $\begin{array}{l}\text { Design review and testing } \\
\text { for code compliance? }\end{array}$ & $\begin{array}{c}\mathrm{CD} \\
\text { Compliance }\end{array}$ & $\begin{array}{c}\text { Code } \\
\text { Compliance }\end{array}$ & $\begin{array}{c}\mathrm{CD} \\
\text { Compliance }\end{array}$ & $\begin{array}{l}\text { CD } \\
\text { Complianc } \\
\mathrm{e}\end{array}$ & $\begin{array}{c}\text { CD } \\
\text { Compliance }\end{array}$ & $\begin{array}{c}\text { Code } \\
\text { Compliance }\end{array}$ & $\begin{array}{c}\mathrm{CD} \\
\text { Compliance }\end{array}$ & $\begin{array}{c}\mathrm{CD} \\
\text { Compliance }\end{array}$ & $\begin{array}{c}\mathrm{CD} \\
\text { Compliance }\end{array}$ & $\begin{array}{c}\text { Code } \\
\text { Compliance }\end{array}$ & $30 \%$ \\
\hline $\begin{array}{l}8.3 \text { How well do } \\
\text { Construction Documents } \\
\text { specify sequence? }\end{array}$ & $\begin{array}{l}\text { Adequate } \\
\text { Specification }\end{array}$ & $\begin{array}{l}\text { Spec Lacks } \\
\text { SetPts or } \\
\text { Schedule }\end{array}$ & $\begin{array}{l}\text { Adequate } \\
\text { Specification }\end{array}$ & $\begin{array}{l}\text { Adequate } \\
\text { Specificati } \\
\text { on }\end{array}$ & $\begin{array}{l}\text { Typically Not } \\
\text { Specified }\end{array}$ & $\begin{array}{l}\text { Adequate } \\
\text { Specification }\end{array}$ & $\begin{array}{l}\text { Adequate } \\
\text { Specification }\end{array}$ & $\begin{array}{l}\text { Spec Lacks } \\
\text { SetPts or } \\
\text { Schedule }\end{array}$ & $\begin{array}{l}\text { Spec Lacks } \\
\text { SetPts or } \\
\text { Schedule }\end{array}$ & $\begin{array}{l}\text { Adequate } \\
\text { Specification }\end{array}$ & $60 \%$ \\
\hline
\end{tabular}




\begin{tabular}{|c|c|c|c|c|c|c|c|c|c|c|c|}
\hline Organization Location & Seattle, WA & $\begin{array}{c}\text { Sacramento } \\
\text { CA }\end{array}$ & $\begin{array}{c}\text { Gainesville } \\
\text { FL }\end{array}$ & Mesa AZ & Dallas TX & Seattle WA & Toronto ON & Denver CO & $\begin{array}{c}\text { Lexington } \\
\mathrm{KY}\end{array}$ & Austin TX & Avg \\
\hline $\begin{array}{l}\text { 8.4 What percent of the } \\
\text { time do you find the } \\
\text { measure meeting code or } \\
\text { requirements on the 1st } \\
\text { pass of functional } \\
\text { testing? }\end{array}$ & 10 & 10 & 10 & 10 & 10 & 10 & 10 & 10 & 10 & 10 & $10 \%$ \\
\hline $\begin{array}{l}8.5 \text { What percent of the } \\
\text { time do you find the } \\
\text { measure meeting code or } \\
\text { requirements at the } \\
\text { completion of } C x \text { ? }\end{array}$ & 10 & 10 & 10 & 10 & 10 & 10 & 10 & 10 & 10 & 10 & $10 \%$ \\
\hline $\begin{array}{l}8.8 \text { If the measure is not } \\
\text { operating as required by } \\
\text { code, what percentage of } \\
\text { buildings have necessary } \\
\text { hardware \& software to } \\
\text { meet code? }\end{array}$ & 100 & 90 & N/A & 100 & 80 & 100 & 100 & 100 & N/A & 100 & $96 \%$ \\
\hline
\end{tabular}




\begin{tabular}{|c|c|c|c|c|c|c|c|c|c|c|c|}
\hline Organization Location & Seattle, WA & $\begin{array}{c}\text { Sacramento } \\
\text { CA }\end{array}$ & $\begin{array}{c}\text { Gainesville } \\
\text { FL }\end{array}$ & Mesa AZ & Dallas TX & Seattle WA & Toronto ON & Denver CO & $\begin{array}{l}\text { Lexington } \\
\mathrm{KY}\end{array}$ & Austin TX & Avg \\
\hline $\begin{array}{l}8.6 \text { What are the common } \\
\text { deficiencies associated } \\
\text { with this measure? }\end{array}$ & $\begin{array}{l}\text { Programming } \\
\text { errors, lack of } \\
\text { understanding }\end{array}$ & $\begin{array}{l}\text { Programmers } \\
\text { don't } \\
\text { understand } \\
\text { the code }\end{array}$ & $\begin{array}{l}\text { Mech of } \\
\text { electrical } \\
\text { failure }\end{array}$ & $\begin{array}{c}\text { Calibration } \\
\text { of VAV } \\
\text { box, } \\
\text { airflow } \\
\text { sensors }\end{array}$ & $\begin{array}{c}\text { Poor } \\
\text { programmin } \\
\text { g, setpts, pt } \\
\text { to pt }\end{array}$ & $\begin{array}{l}\text { Programmin } \\
\text { g, Not a } \\
\text { turn-down } \\
\text { requirement }\end{array}$ & $\begin{array}{l}\text { Contractor } \\
\text { doing his job }\end{array}$ & $\begin{array}{l}\text { Don't look } \\
\text { for } 30 \% \text { VAV } \\
\text { box turn- } \\
\text { down. } 50 \% \\
\text { VAV box } \\
\text { turn-down } \\
\text { typical }\end{array}$ & $\begin{array}{l}\text { Sequences } \\
\text { don't prevent } \\
\text { simultaneou } \\
\text { s heat and } \\
\text { cool, } \\
\text { Leaking } \\
\text { valves, } \\
\text { poorly sized } \\
\text { actuators, } \\
\text { actuator } \\
\text { device } \\
\text { mismatch, } \\
\text { no pilot } \\
\text { positioner }\end{array}$ & $\begin{array}{l}\text { CFM values } \\
\text { not properly } \\
\text { set, TAB, } \\
\text { Flow sensor }\end{array}$ & \\
\hline $\begin{array}{l}8.7 \text { What can be done to } \\
\text { help ensure this measure } \\
\text { is correctly implemented? }\end{array}$ & $\begin{array}{l}\text { Sequence } \\
\text { review, } \\
\text { meetings }\end{array}$ & & $\begin{array}{l}\text { Number of } \\
\text { issues }\end{array}$ & $\begin{array}{l}\text { Adequate } \\
\text { submittal } \\
\text { review }\end{array}$ & same & $?$ & see above & $\begin{array}{l}\text { Good control } \\
\text { sequence }\end{array}$ & $\begin{array}{c}\text { Trend } \\
\text { analysis, } \\
\text { improved } \\
\text { sequences, } \\
\text { FTP, } \\
\text { Temperature } \\
\text { s displayed } \\
\text { on graphics }\end{array}$ & $\begin{array}{l}\text { More training } \\
\text { to engineer, } \\
\text { flow choked } \\
\text { too much }\end{array}$ & \\
\hline \multicolumn{12}{|c|}{ Automatic outdoor air damper controls } \\
\hline $\begin{array}{l}\text { Are you familiar with the } \\
\text { requirement? }\end{array}$ & Very Familiar & Very Familiar & $\begin{array}{l}\text { Never Heard } \\
\text { of It }\end{array}$ & $\begin{array}{c}\text { Very } \\
\text { Familiar }\end{array}$ & $\begin{array}{c}\text { Very } \\
\text { Familiar }\end{array}$ & $\begin{array}{c}\text { Very } \\
\text { Familiar }\end{array}$ & $\begin{array}{l}\text { Somewhat } \\
\text { Familiar }\end{array}$ & $\begin{array}{c}\text { Very } \\
\text { Familiar }\end{array}$ & $\begin{array}{c}\text { Very } \\
\text { Familiar }\end{array}$ & $\begin{array}{l}\text { Somewhat } \\
\text { Familiar }\end{array}$ & \\
\hline $\begin{array}{l}\text { Design review and testing } \\
\text { for code compliance? }\end{array}$ & $\begin{array}{c}\text { Code } \\
\text { Compliance }\end{array}$ & $\begin{array}{l}\text { Code } \\
\text { Compliance }\end{array}$ & $\begin{array}{c}\mathrm{CD} \\
\text { Compliance }\end{array}$ & $\begin{array}{c}\text { CD } \\
\text { Complianc } \\
\mathrm{e}\end{array}$ & $\begin{array}{c}\mathrm{CD} \\
\text { Compliance }\end{array}$ & $\begin{array}{l}\text { Code } \\
\text { Compliance }\end{array}$ & $\begin{array}{c}\mathrm{CD} \\
\text { Compliance }\end{array}$ & $\begin{array}{c}\mathrm{CD} \\
\text { Compliance }\end{array}$ & $\begin{array}{c}\mathrm{CD} \\
\text { Compliance }\end{array}$ & $\begin{array}{c}\mathrm{CD} \\
\text { Compliance }\end{array}$ & $30 \%$ \\
\hline $\begin{array}{l}\text { 9.3 How well do } \\
\text { Construction Documents } \\
\text { specify sequence? }\end{array}$ & $\begin{array}{l}\text { Adequate } \\
\text { Specification }\end{array}$ & $\begin{array}{l}\text { Adequate } \\
\text { Specification }\end{array}$ & $\begin{array}{l}\text { Adequate } \\
\text { Specification }\end{array}$ & $\begin{array}{l}\text { Excellent } \\
\text { Spec With } \\
\text { Diagram }\end{array}$ & $\begin{array}{l}\text { Spec Lacks } \\
\text { SetPts or } \\
\text { Schedule }\end{array}$ & $\begin{array}{l}\text { Excellent } \\
\text { Spec With } \\
\text { Diagram }\end{array}$ & $\begin{array}{l}\text { Spec Lacks } \\
\text { SetPts or } \\
\text { Schedule }\end{array}$ & $\begin{array}{l}\text { Adequate } \\
\text { Specification }\end{array}$ & $\begin{array}{l}\text { Adequate } \\
\text { Specification }\end{array}$ & $\begin{array}{l}\text { Typically Not } \\
\text { Specified }\end{array}$ & $50 \%$ \\
\hline
\end{tabular}




\begin{tabular}{|c|c|c|c|c|c|c|c|c|c|c|c|}
\hline Organization Location & Seattle, WA & $\begin{array}{c}\text { Sacramento } \\
\text { CA }\end{array}$ & $\begin{array}{c}\text { Gainesville } \\
\text { FL }\end{array}$ & Mesa AZ & Dallas TX & Seattle WA & Toronto ON & Denver Co & $\begin{array}{c}\text { Lexington } \\
\mathrm{KY}\end{array}$ & Austin TX & Avg \\
\hline $\begin{array}{l}9.4 \text { What percent of the } \\
\text { time do you find the } \\
\text { measure meeting code or } \\
\text { requirements on the 1st } \\
\text { pass of functional } \\
\text { testing? }\end{array}$ & 90 & 90 & 55 & 90 & 20 & 80 & 80 & 100 & 75 & 0 & $68 \%$ \\
\hline $\begin{array}{l}\text { 9.5 What percent of the } \\
\text { time do you find the } \\
\text { measure meeting code or } \\
\text { requirements at the } \\
\text { completion of } C x \text { ? }\end{array}$ & 100 & 100 & same & 100 & 80 & 100 & 100 & 100 & 100 & 0 & $87 \%$ \\
\hline $\begin{array}{l}9.8 \text { If the measure is not } \\
\text { operating as required by } \\
\text { code, what percentage of } \\
\text { buildings have necessary } \\
\text { hardware \& software to } \\
\text { meet code? }\end{array}$ & 100 & & N/A & 100 & 80 & 100 & 100 & 90 & $\mathrm{~N} / \mathrm{A}$ & 0 & $81 \%$ \\
\hline $\begin{array}{l}\text { 9.6 What are the common } \\
\text { deficiencies associated } \\
\text { with this measure? }\end{array}$ & $\begin{array}{l}\text { Dampers } \\
\text { separate and } \\
\text { must be } \\
\text { interlocked }\end{array}$ & $\begin{array}{l}\text { Could be a lot } \\
\text { and missed }\end{array}$ & $\begin{array}{c}\text { Never seen } \\
\text { damper on } \\
\text { exhaust }\end{array}$ & $\begin{array}{c}\text { Bad } \\
\text { actuator }\end{array}$ & $\begin{array}{c}20 \% \text { no } \\
\text { dampers, } \\
\text { broken } \\
\text { operators, } \\
\text { not } \\
\text { connected to } \\
\text { controls }\end{array}$ & $\begin{array}{l}\text { Improper } \\
\text { installation, } \\
\text { programmin } \\
\text { g }\end{array}$ & $\begin{array}{c}\text { Wiring, } \\
\text { conflict } \\
\text { between CC } \\
\text { and EC, } \\
\text { mech } \\
\text { dampers not } \\
\text { operable }\end{array}$ & $\begin{array}{l}\text { OA dampers } \\
\text { open with } \\
\text { night } \\
\text { heating, } \\
\text { Improper } \\
\text { sequence, } \\
\text { Mech } \\
\text { damper } \\
\text { failure, } \\
\text { Reversed } \\
\text { control } \\
\text { signal }\end{array}$ & $\begin{array}{c}\text { Cheap } \\
\text { dampers, } \\
\text { improper } \\
\text { adjustment } \\
\text { of linkages, } \\
\text { poor } \\
\text { installation }\end{array}$ & Not in design & \\
\hline $\begin{array}{l}9.7 \text { What can be done to } \\
\text { help ensure this measure } \\
\text { is correctly implemented? }\end{array}$ & $\begin{array}{c}\text { Review \& } \\
\text { coordination }\end{array}$ & & $\mathrm{N} / \mathrm{A}$ & $\begin{array}{l}\text { Plan } \\
\text { review, pt } \\
\text { to pt on } \\
\text { dampers }\end{array}$ & same & & & $\begin{array}{c}\text { Proper } \\
\text { specification }\end{array}$ & $\begin{array}{l}\text { Submtl } \\
\text { review, } \\
\text { quality } \\
\text { dampers, } \\
\text { QC by } \\
\text { general } \\
\text { contractor }\end{array}$ & $\begin{array}{l}\text { Code } \\
\text { reviewer } \\
\text { should flag }\end{array}$ & \\
\hline
\end{tabular}




\begin{tabular}{|c|c|c|c|c|c|c|c|c|c|c|c|}
\hline Organization Location & Seattle, WA & $\begin{array}{c}\text { Sacramento } \\
\text { CA }\end{array}$ & $\begin{array}{l}\text { Gainesville } \\
\text { FL }\end{array}$ & Mesa AZ & Dallas TX & Seattle WA & Toronto ON & Denver CO & $\begin{array}{l}\text { Lexington } \\
\mathrm{KY}\end{array}$ & Austin TX & Avg \\
\hline $\begin{array}{l}\text { Are you familiar with the } \\
\text { requirement? }\end{array}$ & Very Familiar & Very Familiar & $\begin{array}{l}\text { Somewhat } \\
\text { Familiar }\end{array}$ & $\begin{array}{l}\text { Very } \\
\text { Familiar }\end{array}$ & $\begin{array}{c}\text { Very } \\
\text { Familiar }\end{array}$ & $\begin{array}{l}\text { Very } \\
\text { Familiar }\end{array}$ & $\begin{array}{l}\text { Never Heard } \\
\text { of It }\end{array}$ & $\begin{array}{l}\text { Very } \\
\text { Familiar }\end{array}$ & $\begin{array}{l}\text { Very } \\
\text { Familiar }\end{array}$ & $\begin{array}{l}\text { Very } \\
\text { Familiar }\end{array}$ & \\
\hline $\begin{array}{l}\text { Design review and testing } \\
\text { for code compliance? }\end{array}$ & $\begin{array}{l}\text { Code } \\
\text { Compliance }\end{array}$ & $\begin{array}{l}\text { Code } \\
\text { Compliance }\end{array}$ & $\begin{array}{c}\mathrm{CD} \\
\text { Compliance }\end{array}$ & $\begin{array}{c}\text { CD } \\
\text { Complianc } \\
\text { e }\end{array}$ & $\begin{array}{c}\mathrm{CD} \\
\text { Compliance }\end{array}$ & $\begin{array}{c}\text { Code } \\
\text { Compliance }\end{array}$ & $\begin{array}{c}\mathrm{CD} \\
\text { Compliance }\end{array}$ & $\begin{array}{c}\mathrm{CD} \\
\text { Compliance }\end{array}$ & $\begin{array}{c}\mathrm{CD} \\
\text { Compliance }\end{array}$ & $\begin{array}{l}\text { Code } \\
\text { Compliance }\end{array}$ & $40 \%$ \\
\hline $\begin{array}{l}\text { 10.3 How well do } \\
\text { Construction Documents } \\
\text { specify sequence? }\end{array}$ & $\begin{array}{l}\text { Spec Lacks } \\
\text { SetPts or } \\
\text { Schedule }\end{array}$ & $\begin{array}{l}\text { Spec Lacks } \\
\text { SetPts or } \\
\text { Schedule }\end{array}$ & $\begin{array}{l}\text { Spec Lacks } \\
\text { SetPts or } \\
\text { Schedule }\end{array}$ & $\begin{array}{c}\text { Spec } \\
\text { Lacks } \\
\text { SetPts or } \\
\text { Schedule } \\
\end{array}$ & $\begin{array}{l}\text { Spec Lacks } \\
\text { SetPts or } \\
\text { Schedule }\end{array}$ & $\begin{array}{l}\text { Adequate } \\
\text { Specification }\end{array}$ & $\begin{array}{l}\text { Typically Not } \\
\text { Specified }\end{array}$ & $\begin{array}{l}\text { Adequate } \\
\text { Specification }\end{array}$ & $\begin{array}{l}\text { Spec Lacks } \\
\text { SetPts or } \\
\text { Schedule }\end{array}$ & $\begin{array}{l}\text { Typically Not } \\
\text { Specified }\end{array}$ & $20 \%$ \\
\hline $\begin{array}{l}10.4 \text { What percent of the } \\
\text { time do you find the } \\
\text { measure meeting code or } \\
\text { requirements on the 1st } \\
\text { pass of functional } \\
\text { testing? }\end{array}$ & 75 & 50 & 40 & 70 & 5 & 70 & 50 & 90 & 25 & 20 & $50 \%$ \\
\hline $\begin{array}{l}10.5 \text { What percent of the } \\
\text { time do you find the } \\
\text { measure meeting code or } \\
\text { requirements at the } \\
\text { completion of Cx? }\end{array}$ & 95 & 90 & 95 & 100 & 80 & 98 & 75 & 100 & 100 & 90 & $92 \%$ \\
\hline $\begin{array}{l}10.8 \text { If the measure is not } \\
\text { operating as required by } \\
\text { code, what percentage of } \\
\text { buildings have necessary } \\
\text { hardware \& software to } \\
\text { meet code? }\end{array}$ & 90 & & N/A & 100 & 50 & 100 & 100 & 100 & N/A & 95 & $91 \%$ \\
\hline $\begin{array}{l}10.6 \text { What are the } \\
\text { common deficiencies } \\
\text { associated with this } \\
\text { measure? }\end{array}$ & $\begin{array}{l}\text { Programming } \\
\text { not looking at } \\
\text { sequence. } \\
\text { Fan energy is } \\
\text { cheaper than } \\
\text { cooling } \\
\text { energy. DAT } \\
\text { based on } \\
\text { space } \\
\text { demand. }\end{array}$ & $\begin{array}{l}\text { Programming } \\
\text {, lack of } \\
\text { understandin } \\
\mathrm{g}\end{array}$ & $\begin{array}{l}\text { Lack of } \\
\text { detailed } \\
\text { sequence }\end{array}$ & $\begin{array}{l}\text { Need to } \\
\text { dial in, } \\
\text { Rate of } \\
\text { response } \\
\text { needs to } \\
\text { dialed in, }\end{array}$ & $\begin{array}{l}\text { Broken } \\
\text { equipment, } \\
\text { programmin } \\
\text { g }\end{array}$ & $\begin{array}{l}\text { Contractor } \\
\text { understandin } \\
\text { g, how to } \\
\text { program }\end{array}$ & $\begin{array}{l}\text { Not doing it } \\
\text { in Ontario, } \\
\text { Use energy } \\
\text { modeling } \\
\text { path, }\end{array}$ & $\begin{array}{l}\text { Different } \\
\text { strategies for } \\
\text { reset }\end{array}$ & $\begin{array}{l}\text { Incorrect } \\
\text { programmin } \\
\text { g, wrong } \\
\text { sequence }\end{array}$ & $\begin{array}{l}\text { Programmin } \\
g\end{array}$ & \\
\hline
\end{tabular}




\begin{tabular}{|c|c|c|c|c|c|c|c|c|c|c|c|}
\hline Organization Location & Seattle, WA & $\begin{array}{c}\text { Sacramento } \\
\text { CA }\end{array}$ & $\begin{array}{c}\text { Gainesville } \\
\text { FL }\end{array}$ & Mesa AZ & Dallas TX & Seattle WA & Toronto ON & Denver CO & $\begin{array}{c}\text { Lexington } \\
\mathrm{KY}\end{array}$ & Austin TX & Avg \\
\hline $\begin{array}{l}10.7 \text { What can be done to } \\
\text { help ensure this measure } \\
\text { is correctly implemented? }\end{array}$ & $\begin{array}{l}\text { Communicatio } \\
\text { n. Field tech } \\
\text { coord with } \\
\text { boss. }\end{array}$ & & $\begin{array}{l}\text { Lack of } \\
\text { detailed } \\
\text { sequence }\end{array}$ & $\begin{array}{l}\text { Sequence } \\
\text { specify } \\
\text { rate or } \\
\text { response }\end{array}$ & same & $\begin{array}{c}\text { Design } \\
\text { intent } \\
\text { meetings }\end{array}$ & N/A & $\begin{array}{l}\text { Good control } \\
\text { sequence }\end{array}$ & $\begin{array}{l}\text { Vendor and } \\
\text { pre-install } \\
\text { meetings }\end{array}$ & $\begin{array}{l}\text { Training for } \\
\text { MEPs }\end{array}$ & \\
\hline \multicolumn{12}{|c|}{ Daylighting controls implemented correctly when required } \\
\hline $\begin{array}{l}\text { Are you familiar with the } \\
\text { requirement? }\end{array}$ & Familiar & Very Familiar & $\begin{array}{l}\text { Somewhat } \\
\text { Familiar }\end{array}$ & $\begin{array}{l}\text { Somewhat } \\
\text { Familiar }\end{array}$ & Familiar & $\begin{array}{c}\text { Very } \\
\text { Familiar }\end{array}$ & $\begin{array}{c}\text { Somewhat } \\
\text { Familiar }\end{array}$ & $\begin{array}{l}\text { Somewhat } \\
\text { Familiar }\end{array}$ & $\begin{array}{c}\text { Very } \\
\text { Familiar } \\
\end{array}$ & $\begin{array}{l}\text { Somewhat } \\
\text { Familiar }\end{array}$ & \\
\hline $\begin{array}{l}\text { Design review and testing } \\
\text { for code compliance? }\end{array}$ & $\begin{array}{l}\text { Code } \\
\text { Compliance }\end{array}$ & $\begin{array}{c}\text { Code } \\
\text { Compliance }\end{array}$ & $\begin{array}{c}\mathrm{CD} \\
\text { Compliance }\end{array}$ & $\begin{array}{l}\text { CD } \\
\text { Complianc } \\
\mathrm{e}\end{array}$ & $\begin{array}{c}\mathrm{CD} \\
\text { Compliance }\end{array}$ & $\begin{array}{c}\text { Code } \\
\text { Compliance }\end{array}$ & $\begin{array}{c}\mathrm{CD} \\
\text { Compliance }\end{array}$ & $\begin{array}{c}\text { Code } \\
\text { Compliance }\end{array}$ & $\begin{array}{c}\mathrm{CD} \\
\text { Compliance }\end{array}$ & $\begin{array}{c}\mathrm{CD} \\
\text { Compliance }\end{array}$ & $40 \%$ \\
\hline $\begin{array}{l}11.3 \text { How well do } \\
\text { Construction Documents } \\
\text { specify sequence? }\end{array}$ & $\begin{array}{l}\text { Spec Lacks } \\
\text { SetPts or } \\
\text { Schedule }\end{array}$ & $\begin{array}{l}\text { Spec Lacks } \\
\text { SetPts or } \\
\text { Schedule }\end{array}$ & $\begin{array}{l}\text { Spec Lacks } \\
\text { SetPts or } \\
\text { Schedule }\end{array}$ & $\begin{array}{c}\text { Spec } \\
\text { Lacks } \\
\text { SetPts or } \\
\text { Schedule } \\
\end{array}$ & $\begin{array}{l}\text { Spec Lacks } \\
\text { SetPts or } \\
\text { Schedule }\end{array}$ & $\begin{array}{c}\text { Adequate } \\
\text { Specification }\end{array}$ & $\begin{array}{l}\text { Spec Lacks } \\
\text { SetPts or } \\
\text { Schedule }\end{array}$ & $\begin{array}{l}\text { Spec Lacks } \\
\text { SetPts or } \\
\text { Schedule }\end{array}$ & $\begin{array}{l}\text { Spec Lacks } \\
\text { SetPts or } \\
\text { Schedule }\end{array}$ & $\begin{array}{l}\text { Typically Not } \\
\text { Specified }\end{array}$ & $10 \%$ \\
\hline $\begin{array}{l}11.4 \text { What percent of the } \\
\text { time do you find the } \\
\text { measure meeting code or } \\
\text { requirements on the 1st } \\
\text { pass of functional } \\
\text { testing? }\end{array}$ & 70 & 60 & 50 & 25 & 5 & 80 & 50 & 80 & 20 & 10 & $45 \%$ \\
\hline $\begin{array}{l}11.5 \text { What percent of the } \\
\text { time do you find the } \\
\text { measure meeting code or } \\
\text { requirements at the } \\
\text { completion of Cx? }\end{array}$ & 95 & 80 & 95 & 85 & 75 & 98 & 95 & 95 & 100 & 15 & $83 \%$ \\
\hline $\begin{array}{l}11.8 \text { If the measure is not } \\
\text { operating as required by } \\
\text { code, what percentage of } \\
\text { buildings have necessary } \\
\text { hardware \& software to } \\
\text { meet code? }\end{array}$ & 100 & & $\mathrm{~N} / \mathrm{A}$ & 100 & 75 & 98 & 80 & 90 & $\mathrm{~N} / \mathrm{A}$ & 15 & $80 \%$ \\
\hline
\end{tabular}




\begin{tabular}{|c|c|c|c|c|c|c|c|c|c|c|c|}
\hline Organization Location & Seattle, WA & $\begin{array}{c}\text { Sacramento } \\
\text { CA }\end{array}$ & $\begin{array}{c}\text { Gainesville } \\
\text { FL }\end{array}$ & Mesa AZ & Dallas TX & Seattle WA & Toronto ON & Denver CO & $\begin{array}{l}\text { Lexington } \\
\mathrm{KY}\end{array}$ & Austin TX & Avg \\
\hline $\begin{array}{l}11.6 \text { What are the } \\
\text { common deficiencies } \\
\text { associated with this } \\
\text { measure? }\end{array}$ & $\begin{array}{l}\text { Sensor } \\
\text { location and } \\
\text { setup }\end{array}$ & $\begin{array}{c}\text { Lack of } \\
\text { sequencing \& } \\
\text { programming }\end{array}$ & $\begin{array}{c}\text { Sensor } \\
\text { location, } \\
\text { programming }\end{array}$ & $\begin{array}{l}\text { Sensor } \\
\text { location, } \\
\text { zoning, }\end{array}$ & $\begin{array}{l}\text { sensor } \\
\text { location } \\
\text { sensitivity } \\
\text { operational }\end{array}$ & $\begin{array}{l}\text { Wiring, } \\
\text { hardware, } \\
\text { sensor } \\
\text { placement }\end{array}$ & $\begin{array}{l}\text { Programmin } \\
\text { g by CC, } \\
\text { specs not } \\
\text { followed }\end{array}$ & $\begin{array}{l}\text { Setpts not } \\
\text { provided, } \\
\text { lighting } \\
\text { fixtures not } \\
\text { identified, } \\
\text { some } \\
\text { daylight } \\
\text { sensors } \\
\text { functional }\end{array}$ & $\begin{array}{c}\text { Sensor } \\
\text { location, } \\
\text { programmin } \\
\mathrm{g} \text {, integration } \\
\text { with } \\
\text { proprietary } \\
\text { components } \\
\text { and controls }\end{array}$ & $\begin{array}{l}\text { Few actually } \\
\text { design for } \\
\text { daylighting, } \\
\text { Calibration, } \\
\text { wiring }\end{array}$ & \\
\hline $\begin{array}{l}11.7 \text { What can be done to } \\
\text { help ensure this measure } \\
\text { is correctly implemented? }\end{array}$ & $\begin{array}{l}\text { Better coord } \\
\text { with installer }\end{array}$ & $\begin{array}{l}\text { Better info } \\
\text { from engineer }\end{array}$ & $\begin{array}{c}\text { Planned } \\
\text { location not } \\
\text { appropriate, } \\
\text { sensor on } \\
\text { wrong circuit } \\
\text { or backwards } \\
\text { wiring }\end{array}$ & $\begin{array}{l}\text { Need to } \\
\text { specify on } \\
\text { plans, } \\
\text { Education } \\
\text { for } \\
\text { installers, } \\
\text { Must know } \\
\text { how to } \\
\text { adjust, mfg } \\
\text { rap often } \\
\text { required }\end{array}$ & same & $\begin{array}{c}\text { Need } \\
\text { lighting tech, } \\
\text { spend more } \\
\text { time, need } \\
\text { good spec }\end{array}$ & $\begin{array}{l}\text { Education, } \\
\text { and better } \\
\text { spec }\end{array}$ & $\begin{array}{c}\text { Design } \\
\text { reviews } \\
\text { critical, \& } \\
\text { submtl } \\
\text { reviews, } \\
\text { Design } \\
\text { criteria, } \\
\text { hardware, \& } \\
\text { programmin } \\
\text { g must be } \\
\text { correct }\end{array}$ & $\begin{array}{l}\text { Coord } \\
\text { designer \& } \\
\text { vendors, } \\
\text { pre-install } \\
\text { mtgs }\end{array}$ & $\begin{array}{l}\text { Education, } \\
\text { AHJ plan } \\
\text { review }\end{array}$ & \\
\hline \multicolumn{12}{|c|}{ Zone isolation controls } \\
\hline $\begin{array}{l}\text { Are you familiar with the } \\
\text { requirement? }\end{array}$ & Familiar & Very Familiar & $\begin{array}{l}\text { Never Heard } \\
\text { of It }\end{array}$ & $\begin{array}{l}\text { Somewhat } \\
\text { Familiar }\end{array}$ & $\begin{array}{c}\text { Very } \\
\text { Familiar }\end{array}$ & $\begin{array}{l}\text { Somewhat } \\
\text { Familiar }\end{array}$ & $\begin{array}{l}\text { Somewhat } \\
\text { Familiar }\end{array}$ & Familiar & Familiar & Familiar & \\
\hline $\begin{array}{l}\text { Design review and testing } \\
\text { for code compliance? }\end{array}$ & $\begin{array}{l}\text { Code } \\
\text { Compliance }\end{array}$ & $\begin{array}{l}\text { Code } \\
\text { Compliance }\end{array}$ & $\begin{array}{c}\mathrm{CD} \\
\text { Compliance }\end{array}$ & $\begin{array}{l}\text { CD } \\
\text { Complianc } \\
\mathrm{e}\end{array}$ & $\begin{array}{c}\mathrm{CD} \\
\text { Compliance }\end{array}$ & $\begin{array}{l}\text { Code } \\
\text { Compliance }\end{array}$ & $\begin{array}{c}\mathrm{CD} \\
\text { Compliance }\end{array}$ & $\begin{array}{c}\mathrm{CD} \\
\text { Compliance }\end{array}$ & $\begin{array}{c}\mathrm{CD} \\
\text { Compliance }\end{array}$ & $\begin{array}{c}\text { General } \\
\text { Expectations }\end{array}$ & $30 \%$ \\
\hline $\begin{array}{l}12.3 \text { How well do } \\
\text { Construction Documents } \\
\text { specify sequence? }\end{array}$ & $\begin{array}{l}\text { Adequate } \\
\text { Specification }\end{array}$ & $\begin{array}{l}\text { Adequate } \\
\text { Specification }\end{array}$ & $\begin{array}{l}\text { Adequate } \\
\text { Specification }\end{array}$ & $\begin{array}{l}\text { Adequate } \\
\text { Specificati } \\
\text { on }\end{array}$ & $\begin{array}{l}\text { Typically Not } \\
\text { Specified }\end{array}$ & & $\begin{array}{l}\text { Adequate } \\
\text { Specification }\end{array}$ & $\begin{array}{l}\text { Adequate } \\
\text { Specification }\end{array}$ & $\begin{array}{l}\text { Spec Lacks } \\
\text { SetPts or } \\
\text { Schedule }\end{array}$ & $\begin{array}{l}\text { Adequate } \\
\text { Specification }\end{array}$ & $70 \%$ \\
\hline $\begin{array}{l}12.4 \text { What percent of the } \\
\text { time do you find the } \\
\text { measure meeting code or } \\
\text { requirements on the 1st } \\
\text { pass of functional } \\
\text { testing? }\end{array}$ & 90 & 90 & 100 & 80 & 5 & & 90 & & 60 & 95 & $76 \%$ \\
\hline
\end{tabular}




\begin{tabular}{|c|c|c|c|c|c|c|c|c|c|c|c|}
\hline Organization Location & Seattle, WA & $\begin{array}{c}\text { Sacramento } \\
\text { CA }\end{array}$ & $\begin{array}{l}\text { Gainesville } \\
\text { FL }\end{array}$ & Mesa AZ & Dallas TX & Seattle WA & Toronto ON & Denver CO & $\begin{array}{l}\text { Lexington } \\
\mathrm{KY}\end{array}$ & Austin TX & Avg \\
\hline $\begin{array}{l}12.5 \text { What percent of the } \\
\text { time do you find the } \\
\text { measure meeting code or } \\
\text { requirements at the } \\
\text { completion of Cx? }\end{array}$ & 90 & 100 & 100 & 100 & 80 & & 100 & & 100 & 95 & $96 \%$ \\
\hline $\begin{array}{l}12.8 \text { If the measure is not } \\
\text { operating as required by } \\
\text { code, what percentage of } \\
\text { buildings have necessary } \\
\text { hardware \& software to } \\
\text { meet code? }\end{array}$ & 90 & & N/A & 100 & 50 & & 100 & & N/A & 25 & $73 \%$ \\
\hline $\begin{array}{l}12.6 \text { What are the } \\
\text { common deficiencies } \\
\text { associated with this } \\
\text { measure? }\end{array}$ & $\begin{array}{l}\text { Design } \\
\text { oversight }\end{array}$ & $\begin{array}{c}\text { Missed } \\
\text { dampers, not } \\
\text { installed }\end{array}$ & No issues & $\begin{array}{l}\text { Verify } \\
\text { dampers } \\
\text { are in } \\
\text { place, pt to } \\
\text { pt testing }\end{array}$ & $\begin{array}{l}\text { Programmin } \\
\text { g, lack of } \\
\text { dampers, } \\
\text { design not } \\
\text { correct, DX } \\
\text { problems }\end{array}$ & $\begin{array}{l}\text { Zones are } \\
\text { never this } \\
\text { large }\end{array}$ & $\begin{array}{l}\mathrm{TAB} \text { and } \mathrm{CC} \\
\text { need to talk }\end{array}$ & & $\begin{array}{l}\text { Calibration } \\
\text { of Setback } \\
\text { control, poor } \\
\text { programmin } \\
\text { g, poor } \\
\text { sequence }\end{array}$ & $\begin{array}{l}\text { Have not } \\
\text { seen } \\
\text { problems }\end{array}$ & \\
\hline $\begin{array}{l}12.7 \text { What can be done to } \\
\text { help ensure this measure } \\
\text { is correctly implemented? }\end{array}$ & Desing review & & N/A & $\begin{array}{l}\text { Design } \\
\text { review }\end{array}$ & Same & & $\begin{array}{l}\text { Education of } \\
\text { contractor }\end{array}$ & & $\begin{array}{l}\text { Design } \\
\text { review, } \\
\text { Functional } \\
\text { Testing }\end{array}$ & & \\
\hline \multicolumn{12}{|c|}{ Demand controlled ventilation } \\
\hline $\begin{array}{l}\text { Are you familiar with the } \\
\text { requirement? }\end{array}$ & Very Familiar & Very Familiar & $\begin{array}{l}\text { Somewhat } \\
\text { Familiar }\end{array}$ & $\begin{array}{l}\text { Very } \\
\text { Familiar }\end{array}$ & $\begin{array}{c}\text { Very } \\
\text { Familiar }\end{array}$ & $\begin{array}{c}\text { Very } \\
\text { Familiar }\end{array}$ & Familiar & $\begin{array}{l}\text { Somewhat } \\
\text { Familiar }\end{array}$ & $\begin{array}{c}\text { Very } \\
\text { Familiar }\end{array}$ & $\begin{array}{c}\text { Very } \\
\text { Familiar }\end{array}$ & \\
\hline $\begin{array}{l}\text { Design review and testing } \\
\text { for code compliance? }\end{array}$ & $\begin{array}{c}\text { Code } \\
\text { Compliance }\end{array}$ & $\begin{array}{c}\text { Code } \\
\text { Compliance }\end{array}$ & $\begin{array}{c}\mathrm{CD} \\
\text { Compliance }\end{array}$ & $\begin{array}{l}\text { CD } \\
\text { Complianc } \\
\mathrm{e}\end{array}$ & $\begin{array}{c}\mathrm{CD} \\
\text { Compliance }\end{array}$ & $\begin{array}{c}\text { Code } \\
\text { Compliance }\end{array}$ & $\begin{array}{c}\mathrm{CD} \\
\text { Compliance }\end{array}$ & $\begin{array}{c}\mathrm{CD} \\
\text { Compliance }\end{array}$ & $\begin{array}{c}\mathrm{CD} \\
\text { Compliance }\end{array}$ & $\begin{array}{c}\mathrm{CD} \\
\text { Compliance }\end{array}$ & $30 \%$ \\
\hline $\begin{array}{l}\text { 13.3 How well do } \\
\text { Construction Documents } \\
\text { specify sequence? }\end{array}$ & $\begin{array}{l}\text { Adequate } \\
\text { Specification }\end{array}$ & $\begin{array}{l}\text { Adequate } \\
\text { Specification }\end{array}$ & $\begin{array}{l}\text { Spec Lacks } \\
\text { SetPts or } \\
\text { Schedule }\end{array}$ & $\begin{array}{c}\text { Spec } \\
\text { Lacks } \\
\text { SetPts or } \\
\text { Schedule } \\
\end{array}$ & $\begin{array}{l}\text { Spec Lacks } \\
\text { SetPts or } \\
\text { Schedule }\end{array}$ & $\begin{array}{l}\text { Adequate } \\
\text { Specification }\end{array}$ & $\begin{array}{l}\text { Spec Lacks } \\
\text { SetPts or } \\
\text { Schedule }\end{array}$ & $\begin{array}{l}\text { Adequate } \\
\text { Specification }\end{array}$ & $\begin{array}{l}\text { Spec Lacks } \\
\text { SetPts or } \\
\text { Schedule }\end{array}$ & $\begin{array}{l}\text { Typically Not } \\
\text { Specified }\end{array}$ & $40 \%$ \\
\hline $\begin{array}{l}\text { 13.4 What percent of the } \\
\text { time do you find the } \\
\text { measure meeting code or } \\
\text { requirements on the 1st } \\
\text { pass of functional } \\
\text { testing? }\end{array}$ & 85 & 90 & 50 & 25 & 20 & 80 & 75 & 60 & 50 & 20 & $56 \%$ \\
\hline
\end{tabular}




\begin{tabular}{|c|c|c|c|c|c|c|c|c|c|c|c|}
\hline Organization Location & Seattle, WA & $\begin{array}{c}\text { Sacramento } \\
\text { CA }\end{array}$ & $\begin{array}{l}\text { Gainesville } \\
\text { FL }\end{array}$ & Mesa AZ & Dallas TX & Seattle WA & Toronto ON & Denver CO & $\begin{array}{l}\text { Lexington } \\
\mathrm{KY}\end{array}$ & Austin TX & Avg \\
\hline $\begin{array}{l}13.5 \text { What percent of the } \\
\text { time do you find the } \\
\text { measure meeting code or } \\
\text { requirements at the } \\
\text { completion of Cx? }\end{array}$ & 95 & 100 & 95 & 90 & 80 & 98 & 100 & 90 & 100 & 60 & $91 \%$ \\
\hline $\begin{array}{l}13.8 \text { If the measure is not } \\
\text { operating as required by } \\
\text { code, what percentage of } \\
\text { buildings have necessary } \\
\text { hardware \& software to } \\
\text { meet code? }\end{array}$ & 100 & & $\mathrm{~N} / \mathrm{A}$ & 100 & 75 & 90 & 50 & 100 & $\mathrm{~N} / \mathrm{A}$ & 40 & $79 \%$ \\
\hline $\begin{array}{l}\text { 13.6 What are the } \\
\text { common deficiencies } \\
\text { associated with this } \\
\text { measure? }\end{array}$ & $\begin{array}{l}\text { Sensor } \\
\text { calibration }\end{array}$ & $\begin{array}{l}\text { Programming } \\
\text { doesn't meet } \\
\text { sequence }\end{array}$ & $\begin{array}{l}\text { Calibration of } \\
\text { CO@ and } \\
\text { outside air } \\
\text { flow }\end{array}$ & $\begin{array}{l}\text { Design not } \\
\text { correct, } \\
\text { does not } \\
\text { drop below } \\
\text { min } \\
\text { ventilation, }\end{array}$ & $\begin{array}{l}\text { Lack of } \\
\text { sensor or } \\
\text { location, }\end{array}$ & $\begin{array}{l}\text { Programmin } \\
\text { g, } \mathrm{CO}_{2} \\
\text { sensors } \\
\text { failed }\end{array}$ & Setpts, & $\begin{array}{l}\text { OA damper } \\
\text { opening fully }\end{array}$ & $\begin{array}{l}\text { Incorrect } \\
\text { setpt, poor } \\
\text { sequence, } \\
\text { failure to } \\
\text { provide } \mathrm{CO}_{2}\end{array}$ & $\begin{array}{c}\text { Not } \\
\text { designed, } \\
\text { software and } \\
\text { hardware not } \\
\text { in place, } \\
\text { calibration of } \\
\text { sensors and } \\
\text { dampers, } \\
\text { Not } \\
\text { accounting } \\
\text { for variable } \\
\text { speed of } \\
\text { fans. }\end{array}$ & \\
\hline $\begin{array}{l}13.7 \text { What can be done to } \\
\text { help ensure this measure } \\
\text { is correctly implemented? }\end{array}$ & $\begin{array}{l}\text { Coord } \\
\text { meeting }\end{array}$ & & $\begin{array}{l}\text { Meeting on } \\
\text { AFMS } \\
\text { location and } \\
\text { installation }\end{array}$ & $\begin{array}{c}\mathrm{CO}_{2} \text { limits } \\
\text { and } \mathrm{OA} \\
\mathrm{CO}_{2} \\
\text { reference, } \\
\text { Proper } \\
\text { specificatio } \\
\mathrm{n}\end{array}$ & Same & $\begin{array}{l}\mathrm{CO}_{2} \text { in single } \\
\text { zones, }\end{array}$ & $\begin{array}{l}\text { Better spec, } \\
\text { Better } \\
\text { sequence on } \\
\text { inlet and } \\
\text { exhaust fans }\end{array}$ & $\begin{array}{l}\text { Detailed } \\
\text { control } \\
\text { sequence }\end{array}$ & & $\begin{array}{l}\text { AHJ not } \\
\text { enforcing, } \\
\text { MEP know } \\
\text { it's not } \\
\text { enforced. }\end{array}$ & \\
\hline \multicolumn{12}{|c|}{ Exterior lighting controls } \\
\hline $\begin{array}{l}\text { Are you familiar with the } \\
\text { requirement? }\end{array}$ & Very Familiar & Very Familiar & $\begin{array}{l}\text { Never Heard } \\
\text { of It }\end{array}$ & Familiar & $\begin{array}{l}\text { Very } \\
\text { Familiar }\end{array}$ & $\begin{array}{c}\text { Very } \\
\text { Familiar }\end{array}$ & $\begin{array}{l}\text { Somewhat } \\
\text { Familiar }\end{array}$ & Familiar & $\begin{array}{c}\text { Very } \\
\text { Familiar }\end{array}$ & Familiar & \\
\hline
\end{tabular}




\begin{tabular}{|c|c|c|c|c|c|c|c|c|c|c|c|}
\hline Organization Location & Seattle, WA & $\begin{array}{c}\text { Sacramento } \\
\text { CA }\end{array}$ & $\begin{array}{l}\text { Gainesville } \\
\text { FL }\end{array}$ & Mesa AZ & Dallas TX & Seattle WA & Toronto ON & Denver CO & $\begin{array}{l}\text { Lexington } \\
\mathrm{KY}\end{array}$ & Austin TX & Avg \\
\hline $\begin{array}{l}\text { Design review and testing } \\
\text { for code compliance? }\end{array}$ & $\begin{array}{l}\text { Code } \\
\text { Compliance }\end{array}$ & $\begin{array}{l}\text { Code } \\
\text { Compliance }\end{array}$ & $\begin{array}{c}\mathrm{CD} \\
\text { Compliance }\end{array}$ & $\begin{array}{l}\text { CD } \\
\text { Complianc } \\
\mathrm{e}\end{array}$ & $\begin{array}{c}\mathrm{CD} \\
\text { Compliance }\end{array}$ & $\begin{array}{l}\text { Code } \\
\text { Compliance }\end{array}$ & $\begin{array}{c}\mathrm{CD} \\
\text { Compliance }\end{array}$ & $\begin{array}{l}\text { Code } \\
\text { Compliance }\end{array}$ & $\begin{array}{c}\mathrm{CD} \\
\text { Compliance }\end{array}$ & $\begin{array}{l}\text { Code } \\
\text { Compliance }\end{array}$ & $50 \%$ \\
\hline $\begin{array}{l}\text { 14.3 How well do } \\
\text { Construction Documents } \\
\text { specify sequence? }\end{array}$ & $\begin{array}{l}\text { Adequate } \\
\text { Specification }\end{array}$ & $\begin{array}{l}\text { Adequate } \\
\text { Specification }\end{array}$ & $\begin{array}{l}\text { Adequate } \\
\text { Specification }\end{array}$ & $\begin{array}{l}\text { Typically } \\
\text { Not } \\
\text { Specified }\end{array}$ & $\begin{array}{l}\text { Typically Not } \\
\text { Specified }\end{array}$ & $\begin{array}{l}\text { Spec Lacks } \\
\text { SetPts or } \\
\text { Schedule }\end{array}$ & $\begin{array}{l}\text { Typically Not } \\
\text { Specified }\end{array}$ & $\begin{array}{l}\text { Adequate } \\
\text { Specification }\end{array}$ & $\begin{array}{l}\text { Spec Lacks } \\
\text { SetPts or } \\
\text { Schedule }\end{array}$ & $\begin{array}{l}\text { Typically Not } \\
\text { Specified }\end{array}$ & $40 \%$ \\
\hline $\begin{array}{l}14.4 \text { What percent of the } \\
\text { time do you find the } \\
\text { measure meeting code or } \\
\text { requirements on the 1st } \\
\text { pass of functional } \\
\text { testing? }\end{array}$ & 90 & 100 & 50 & 10 & 10 & 50 & 50 & 95 & 60 & 30 & $55 \%$ \\
\hline $\begin{array}{l}14.5 \text { What percent of the } \\
\text { time do you find the } \\
\text { measure meeting code or } \\
\text { requirements at the } \\
\text { completion of Cx? }\end{array}$ & 95 & 100 & 95 & 50 & 80 & 95 & 90 & 100 & 100 & 60 & $87 \%$ \\
\hline $\begin{array}{l}14.8 \text { If the measure is not } \\
\text { operating as required by } \\
\text { code, what percentage of } \\
\text { buildings have necessary } \\
\text { hardware \& software to } \\
\text { meet code? }\end{array}$ & 100 & & N/A & 90 & 75 & 100 & 75 & 100 & N/A & 60 & $86 \%$ \\
\hline $\begin{array}{l}14.6 \text { What are the } \\
\text { common deficiencies } \\
\text { associated with this } \\
\text { measure? }\end{array}$ & $\begin{array}{c}\text { Sensor } \\
\text { location \& } \\
\text { calibration \& } \\
\text { programming }\end{array}$ & $\begin{array}{l}\text { Hard wired } \\
\text { system }\end{array}$ & $\begin{array}{l}\text { Wiring } \\
\text { problems }\end{array}$ & $\begin{array}{l}\text { Poor } \\
\text { specificatio } \\
\text { n, Never } \\
\text { seen } \\
\text { sequence } \\
\text { meeting } \\
\text { code, }\end{array}$ & $\begin{array}{l}\text { No sensor or } \\
\text { bad location, } \\
\text { missing } \\
\text { controls, can } \\
\text { get } \\
\text { complicated, } \\
\text { motion } \\
\text { sensors }\end{array}$ & $\begin{array}{l}\text { Programmin } \\
\mathrm{g}\end{array}$ & $\begin{array}{l}\text { Timing of } \\
\text { construction, } \\
\text { controls not } \\
\text { installed or } \\
\text { programmed } \\
\text { to the last } \\
\text { minute. }\end{array}$ & $\begin{array}{l}\text { Timeclock } \\
\text { not } \\
\text { programmed }\end{array}$ & $\begin{array}{l}\text { Conflict } \\
\text { between } \\
\text { photosensor } \\
\& \text { program, } \\
\text { poor specs }\end{array}$ & $\begin{array}{l}\text { Not } \\
\text { designed or } \\
\text { installed, In } \\
\text { but not } \\
\text { operating to } \\
\text { sequence }\end{array}$ & \\
\hline
\end{tabular}




\begin{tabular}{|c|c|c|c|c|c|c|c|c|c|c|c|}
\hline Organization Location & Seattle, WA & $\begin{array}{c}\text { Sacramento } \\
\text { CA }\end{array}$ & $\begin{array}{l}\text { Gainesville } \\
\text { FL }\end{array}$ & Mesa AZ & Dallas TX & Seattle WA & Toronto ON & Denver CO & $\begin{array}{l}\text { Lexington } \\
\mathrm{KY}\end{array}$ & Austin TX & Avg \\
\hline $\begin{array}{l}14.7 \text { What can be done to } \\
\text { help ensure this measure } \\
\text { is correctly implemented? }\end{array}$ & $\begin{array}{l}\text { Coord etc, } \\
\text { different } \\
\text { contractor }\end{array}$ & & $\begin{array}{c}\text { Better } \\
\text { sequences }\end{array}$ & $\begin{array}{c}\text { Good } \\
\text { specificatio } \\
\text { ns }\end{array}$ & Same & Coordination & $\begin{array}{l}\text { Better } \\
\text { contractor } \\
\text { project } \\
\text { managemen } \\
\text { t, Better } \\
\text { spec }\end{array}$ & $\begin{array}{l}\text { Testing, } \\
\text { owner O\&M } \\
\text { testing, } \\
\text { Getting the } \\
\text { contractor } \\
\text { back onsite }\end{array}$ & $\begin{array}{l}\text { Pre install } \\
\text { mtg \& } \\
\text { Functional } \\
\text { Testing }\end{array}$ & $\begin{array}{c}\text { AHJ } \\
\text { enforcement, } \\
\text { technology } \\
\text { LED with } \\
\text { built-in } \\
\text { systems, } \\
\text { Training }\end{array}$ & \\
\hline & & & & & & & & & & & \\
\hline \multicolumn{12}{|c|}{ Fan static pressure reset controls } \\
\hline $\begin{array}{l}\text { Are you familiar with the } \\
\text { requirement? }\end{array}$ & Very Familiar & $\begin{array}{c}\text { Very } \\
\text { Familiar }\end{array}$ & $\begin{array}{l}\text { Somewhat } \\
\text { Familiar }\end{array}$ & $\begin{array}{l}\text { Very } \\
\text { Familiar }\end{array}$ & $\begin{array}{c}\text { Very } \\
\text { Familiar }\end{array}$ & $\begin{array}{c}\text { Very } \\
\text { Familiar }\end{array}$ & $\begin{array}{l}\text { Somewhat } \\
\text { Familiar }\end{array}$ & $\begin{array}{c}\text { Very } \\
\text { Familiar }\end{array}$ & $\begin{array}{c}\text { Very } \\
\text { Familiar }\end{array}$ & $\begin{array}{l}\text { Somewhat } \\
\text { Familiar }\end{array}$ & \\
\hline $\begin{array}{l}\text { Design review and testing } \\
\text { for code compliance? }\end{array}$ & $\begin{array}{l}\text { Code } \\
\text { Compliance }\end{array}$ & $\begin{array}{l}\text { Code } \\
\text { Compliance }\end{array}$ & $\begin{array}{c}\mathrm{CD} \\
\text { Compliance }\end{array}$ & $\begin{array}{c}\mathrm{CD} \\
\text { Complianc } \\
\mathrm{e}\end{array}$ & $\begin{array}{c}\mathrm{CD} \\
\text { Compliance }\end{array}$ & $\begin{array}{c}\text { Code } \\
\text { Compliance }\end{array}$ & $\begin{array}{c}\mathrm{CD} \\
\text { Compliance }\end{array}$ & $\begin{array}{c}\mathrm{CD} \\
\text { Compliance }\end{array}$ & $\begin{array}{c}\mathrm{CD} \\
\text { Compliance }\end{array}$ & $\begin{array}{c}\mathrm{CD} \\
\text { Compliance }\end{array}$ & $30 \%$ \\
\hline $\begin{array}{l}15.3 \text { How well do } \\
\text { Construction Documents } \\
\text { specify sequence? }\end{array}$ & $\begin{array}{l}\text { Adequate } \\
\text { Specification }\end{array}$ & $\begin{array}{l}\text { Spec Lacks } \\
\text { SetPts or } \\
\text { Schedule }\end{array}$ & $\begin{array}{c}\text { Spec Lacks } \\
\text { SetPts or } \\
\text { Schedule }\end{array}$ & $\begin{array}{c}\text { Spec } \\
\text { Lacks } \\
\text { SetPts or } \\
\text { Schedule }\end{array}$ & $\begin{array}{l}\text { Spec Lacks } \\
\text { SetPts or } \\
\text { Schedule }\end{array}$ & $\begin{array}{l}\text { Adequate } \\
\text { Specification }\end{array}$ & $\begin{array}{l}\text { Typically Not } \\
\text { Specified }\end{array}$ & $\begin{array}{l}\text { Adequate } \\
\text { Specification }\end{array}$ & $\begin{array}{c}\text { Spec Lacks } \\
\text { SetPts or } \\
\text { Schedule }\end{array}$ & $\begin{array}{l}\text { Typically Not } \\
\text { Specified }\end{array}$ & $30 \%$ \\
\hline $\begin{array}{l}15.4 \text { What percent of the } \\
\text { time do you find the } \\
\text { measure meeting code or } \\
\text { requirements on the 1st } \\
\text { pass of functional } \\
\text { testing? }\end{array}$ & 90 & 50 & 50 & 75 & 5 & 75 & 80 & 75 & 20 & 25 & $55 \%$ \\
\hline $\begin{array}{l}15.5 \text { What percent of the } \\
\text { time do you find the } \\
\text { measure meeting code or } \\
\text { requirements at the } \\
\text { completion of Cx? }\end{array}$ & 95 & 90 & 95 & 95 & 75 & 98 & 100 & 95 & 100 & 80 & $92 \%$ \\
\hline $\begin{array}{l}15.8 \text { If the measure is not } \\
\text { operating as required by } \\
\text { code, what percentage of } \\
\text { buildings have necessary } \\
\text { hardware \& software to } \\
\text { meet code? }\end{array}$ & 100 & & $\mathrm{~N} / \mathrm{a}$ & 100 & 80 & 100 & 100 & 100 & N/A & 80 & $94 \%$ \\
\hline
\end{tabular}




\begin{tabular}{|c|c|c|c|c|c|c|c|c|c|c|c|}
\hline Organization Location & Seattle, WA & $\begin{array}{c}\text { Sacramento } \\
\text { CA }\end{array}$ & $\begin{array}{l}\text { Gainesville } \\
\text { FL }\end{array}$ & Mesa AZ & Dallas TX & Seattle WA & Toronto ON & Denver Co & $\begin{array}{l}\text { Lexington } \\
\mathrm{KY}\end{array}$ & Austin TX & Avg \\
\hline $\begin{array}{l}15.6 \text { What are the } \\
\text { common deficiencies } \\
\text { associated with this } \\
\text { measure? }\end{array}$ & $\begin{array}{l}\text { Programming, } \\
\text { sensor location }\end{array}$ & $\begin{array}{c}\text { Poor } \\
\text { sequence }\end{array}$ & $\begin{array}{c}\text { Poor } \\
\text { sequence } \\
\text { leads to poor } \\
\text { programming }\end{array}$ & $\begin{array}{l}\text { Monitoring } \\
\text { \& alarming } \\
\text { spec, high } \\
\text { \& low } \\
\text { limits, rate } \\
\text { of } \\
\text { response }\end{array}$ & $\begin{array}{c}\text { Sensor } \\
\text { placement, } \\
\text { type, How is } \\
\text { setback } \\
\text { programmed } \\
?\end{array}$ & $\begin{array}{l}\text { Programmin } \\
\mathrm{g} \text {, hardware }\end{array}$ & $\begin{array}{l}\text { Programmin } \\
\mathrm{g}\end{array}$ & $\begin{array}{l}\text { Duct static } \\
\text { above max, } \\
\text { Reset } \\
\text { amount is } \\
\text { too much of } \\
\text { too little }\end{array}$ & $\begin{array}{l}\text { DP sensor } \\
\text { location, } \\
\text { TAB } \\
\text { deficiencies, } \\
\text { wrong } \\
\text { sequence }\end{array}$ & $\begin{array}{l}\text { Not specified } \\
\text { or } \\
\text { programmed } \\
\text {, calibration } \\
\text { of sensors }\end{array}$ & \\
\hline $\begin{array}{l}15.7 \text { What can be done to } \\
\text { help ensure this measure } \\
\text { is correctly implemented? }\end{array}$ & Coordination & & $\begin{array}{l}\text { Good } \\
\text { sequences }\end{array}$ & $\begin{array}{l}\text { Design } \\
\text { review, } \\
\text { setpt } \\
\text { present, } \\
\text { functional } \\
\text { testing }\end{array}$ & Same & $\begin{array}{l}\text { Understand } \\
\text { design intent }\end{array}$ & & $\begin{array}{l}\text { Good control } \\
\text { sequence }\end{array}$ & $\begin{array}{l}\text { Good control } \\
\text { sequence, } \\
\text { Functional } \\
\text { testing }\end{array}$ & $\begin{array}{c}\text { Resistance } \\
\text { from O\&M } \\
\text { personnel, } \\
\text { need more } \\
\text { education to } \\
\text { end users, } \\
\text { they think it's } \\
\text { too } \\
\text { complicated. }\end{array}$ & \\
\hline & & & & & & & & & & & \\
\hline \multicolumn{12}{|c|}{ Timer-based interior lighting controls } \\
\hline $\begin{array}{l}\text { Are you familiar with the } \\
\text { requirement? }\end{array}$ & $\begin{array}{l}\text { Somewhat } \\
\text { Familiar }\end{array}$ & Very Familiar & $\begin{array}{l}\text { Never Heard } \\
\text { of It }\end{array}$ & $\begin{array}{l}\text { Somewhat } \\
\text { Familiar }\end{array}$ & $\begin{array}{c}\text { Very } \\
\text { Familiar }\end{array}$ & $\begin{array}{c}\text { Very } \\
\text { Familiar }\end{array}$ & $\begin{array}{l}\text { Never Heard } \\
\text { of It }\end{array}$ & $\begin{array}{c}\text { Very } \\
\text { Familiar }\end{array}$ & $\begin{array}{c}\text { Very } \\
\text { Familiar }\end{array}$ & Familiar & \\
\hline $\begin{array}{l}\text { Design review and testing } \\
\text { for code compliance? }\end{array}$ & $\begin{array}{c}\text { Code } \\
\text { Compliance }\end{array}$ & $\begin{array}{l}\text { Code } \\
\text { Compliance }\end{array}$ & $\begin{array}{c}\mathrm{CD} \\
\text { Compliance }\end{array}$ & $\begin{array}{l}\text { CD } \\
\text { Complianc } \\
\mathrm{e}\end{array}$ & $\begin{array}{c}\mathrm{CD} \\
\text { Compliance }\end{array}$ & $\begin{array}{c}\mathrm{CD} \\
\text { Compliance }\end{array}$ & $\begin{array}{c}\mathrm{CD} \\
\text { Compliance }\end{array}$ & $\begin{array}{l}\text { Code } \\
\text { Compliance }\end{array}$ & $\begin{array}{c}\mathrm{CD} \\
\text { Compliance }\end{array}$ & $\begin{array}{c}\mathrm{CD} \\
\text { Compliance }\end{array}$ & $30 \%$ \\
\hline $\begin{array}{l}16.3 \text { How well do } \\
\text { Construction Documents } \\
\text { specify sequence? }\end{array}$ & $\begin{array}{l}\text { Adequate } \\
\text { Specification }\end{array}$ & $\begin{array}{l}\text { Adequate } \\
\text { Specification }\end{array}$ & $\begin{array}{l}\text { Typically Not } \\
\text { Specified }\end{array}$ & $\begin{array}{c}\text { Spec } \\
\text { Lacks } \\
\text { SetPts or } \\
\text { Schedule } \\
\end{array}$ & $\begin{array}{l}\text { Spec Lacks } \\
\text { SetPts or } \\
\text { Schedule }\end{array}$ & $\begin{array}{l}\text { Adequate } \\
\text { Specification }\end{array}$ & $\begin{array}{l}\text { Typically Not } \\
\text { Specified }\end{array}$ & $\begin{array}{l}\text { Adequate } \\
\text { Specification }\end{array}$ & $\begin{array}{l}\text { Spec Lacks } \\
\text { SetPts or } \\
\text { Schedule }\end{array}$ & $\begin{array}{l}\text { Typically Not } \\
\text { Specified }\end{array}$ & $40 \%$ \\
\hline $\begin{array}{l}16.4 \text { What percent of the } \\
\text { time do you find the } \\
\text { measure meeting code or } \\
\text { requirements on the 1st } \\
\text { pass of functional } \\
\text { testing? }\end{array}$ & 90 & 85 & 50 & 75 & 10 & 75 & 50 & 99 & 20 & 25 & $58 \%$ \\
\hline $\begin{array}{l}16.5 \text { What percent of the } \\
\text { time do you find the } \\
\text { measure meeting code or } \\
\text { requirements at the } \\
\text { completion of } C x \text { ? }\end{array}$ & 100 & 100 & 95 & 100 & 80 & 98 & 90 & 100 & 100 & 40 & $90 \%$ \\
\hline
\end{tabular}




\begin{tabular}{|c|c|c|c|c|c|c|c|c|c|c|c|}
\hline Organization Location & Seattle, WA & $\begin{array}{c}\text { Sacramento } \\
\text { CA }\end{array}$ & $\begin{array}{l}\text { Gainesville } \\
\text { FL }\end{array}$ & Mesa AZ & Dallas TX & Seattle WA & Toronto ON & Denver CO & $\begin{array}{l}\text { Lexington } \\
\mathrm{KY}\end{array}$ & Austin TX & Avg \\
\hline $\begin{array}{l}16.8 \text { If the measure is not } \\
\text { operating as required by } \\
\text { code, what percentage of } \\
\text { buildings have necessary } \\
\text { hardware \& software to } \\
\text { meet code? }\end{array}$ & 100 & & $\mathrm{~N} / \mathrm{A}$ & 100 & 75 & 98 & 75 & 100 & N/A & 40 & $84 \%$ \\
\hline $\begin{array}{l}16.6 \text { What are the } \\
\text { common deficiencies } \\
\text { associated with this } \\
\text { measure? }\end{array}$ & Zone & $\begin{array}{l}\text { Unaware of } \\
\text { scheduled }\end{array}$ & $\begin{array}{l}\text { Wiring, } \\
\text { incorrect } \\
\text { zones, BAS } \\
\text { and lighting } \\
\text { controls not } \\
\text { compatible }\end{array}$ & $\begin{array}{l}\text { Scheduling } \\
\text { does not } \\
\text { match } \\
\text { occupancy } \\
\text {, }\end{array}$ & $\begin{array}{l}\text { Wrong } \\
\text { sensor or } \\
\text { location, } \\
\text { programmin } \\
\text { g, setpts, } \\
\text { schedules, } \\
\text { time clock }\end{array}$ & $\begin{array}{l}\text { Programmin } \\
\text { g, circuiting }\end{array}$ & $\begin{array}{l}\text { Programmin } \\
\mathrm{g},\end{array}$ & $\begin{array}{l}\text { Schedule } \\
\text { selection }\end{array}$ & $\begin{array}{c}\text { Timeclock } \\
\text { not correctly } \\
\text { programmed } \\
\text {, Occupants } \\
\text { do not } \\
\text { provide } \\
\text { schedule }\end{array}$ & $\begin{array}{l}\text { Not } \\
\text { designed or } \\
\text { installed, } \\
\text { programmin } \\
\text { g or } \\
\text { scheduling }\end{array}$ & \\
\hline $\begin{array}{l}16.7 \text { What can be done to } \\
\text { help ensure this measure } \\
\text { is correctly implemented? }\end{array}$ & Coord & & $\begin{array}{l}\text { Integration } \\
\text { type meeting }\end{array}$ & $\begin{array}{l}\text { Occupancy } \\
\text { sched from } \\
\text { MEP or } \\
\text { owner }\end{array}$ & Same & $\begin{array}{l}\text { More time } \\
\text { from lighting } \\
\text { tech }\end{array}$ & $\begin{array}{l}\text { cord on } \\
\text { zoning in } \\
\text { design }\end{array}$ & & $\begin{array}{l}\text { Better } \\
\text { coordination } \\
\text { with owner, } \\
\text { submittal } \\
\text { review of } \\
\text { timeclock }\end{array}$ & $\begin{array}{l}\text { Education to } \\
\text { bldg end } \\
\text { users }\end{array}$ & \\
\hline & & & & & & & & & & & \\
\hline \multicolumn{12}{|c|}{ Optimum start controls } \\
\hline $\begin{array}{l}\text { Are you familiar with the } \\
\text { requirement? }\end{array}$ & Very Familiar & $\begin{array}{l}\text { Somewhat } \\
\text { Familiar }\end{array}$ & $\begin{array}{l}\text { Somewhat } \\
\text { Familiar }\end{array}$ & $\begin{array}{c}\text { Very } \\
\text { Familiar }\end{array}$ & $\begin{array}{c}\text { Very } \\
\text { Familiar }\end{array}$ & $\begin{array}{l}\text { Very } \\
\text { Familiar }\end{array}$ & $\begin{array}{l}\text { Somewhat } \\
\text { Familiar }\end{array}$ & $\begin{array}{l}\text { Very } \\
\text { Familiar }\end{array}$ & $\begin{array}{c}\text { Very } \\
\text { Familiar }\end{array}$ & Familiar & \\
\hline $\begin{array}{l}\text { Design review and testing } \\
\text { for code compliance? }\end{array}$ & $\begin{array}{l}\text { Code } \\
\text { Compliance }\end{array}$ & $\begin{array}{l}\text { Code } \\
\text { Compliance }\end{array}$ & $\begin{array}{c}\mathrm{CD} \\
\text { Compliance }\end{array}$ & $\begin{array}{l}\text { CD } \\
\text { Complianc } \\
\mathrm{e}\end{array}$ & $\begin{array}{c}\mathrm{CD} \\
\text { Compliance }\end{array}$ & $\begin{array}{c}\text { Code } \\
\text { Compliance }\end{array}$ & $\begin{array}{c}\mathrm{CD} \\
\text { Compliance }\end{array}$ & $\begin{array}{c}\mathrm{CD} \\
\text { Compliance }\end{array}$ & $\begin{array}{c}\mathrm{CD} \\
\text { Compliance }\end{array}$ & $\begin{array}{c}\text { Code } \\
\text { Compliance }\end{array}$ & $40 \%$ \\
\hline $\begin{array}{l}17.3 \text { How well do } \\
\text { Construction Documents } \\
\text { specify sequence? }\end{array}$ & $\begin{array}{l}\text { Spec Lacks } \\
\text { SetPts or } \\
\text { Schedule }\end{array}$ & $\begin{array}{l}\text { Typically Not } \\
\text { Specified }\end{array}$ & $\begin{array}{l}\text { Typically Not } \\
\text { Specified }\end{array}$ & $\begin{array}{l}\text { Adequate } \\
\text { Specificati } \\
\text { on }\end{array}$ & $\begin{array}{l}\text { Spec Lacks } \\
\text { SetPts or } \\
\text { Schedule }\end{array}$ & $\begin{array}{l}\text { Adequate } \\
\text { Specification }\end{array}$ & $\begin{array}{l}\text { Spec Lacks } \\
\text { SetPts or } \\
\text { Schedule }\end{array}$ & $\begin{array}{l}\text { Adequate } \\
\text { Specification }\end{array}$ & $\begin{array}{l}\text { Adequate } \\
\text { Specification }\end{array}$ & $\begin{array}{l}\text { Typically Not } \\
\text { Specified }\end{array}$ & $40 \%$ \\
\hline $\begin{array}{l}17.4 \text { What percent of the } \\
\text { time do you find the } \\
\text { measure meeting code or } \\
\text { requirements on the 1st } \\
\text { pass of functional } \\
\text { testing? }\end{array}$ & 90 & 10 & & 50 & 20 & 30 & 50 & 50 & 10 & 10 & $36 \%$ \\
\hline
\end{tabular}




\begin{tabular}{|c|c|c|c|c|c|c|c|c|c|c|c|}
\hline Organization Location & Seattle, WA & $\begin{array}{c}\text { Sacramento } \\
\text { CA }\end{array}$ & $\begin{array}{c}\text { Gainesville } \\
\text { FL }\end{array}$ & Mesa AZ & Dallas TX & Seattle WA & Toronto ON & Denver CO & $\begin{array}{l}\text { Lexington } \\
\mathrm{KY}\end{array}$ & Austin TX & Avg \\
\hline $\begin{array}{l}17.5 \text { What percent of the } \\
\text { time do you find the } \\
\text { measure meeting code or } \\
\text { requirements at the } \\
\text { completion of Cx? }\end{array}$ & 90 & 25 & N/A & 75 & 80 & 90 & 75 & 75 & 100 & 90 & $78 \%$ \\
\hline $\begin{array}{l}17.8 \text { If the measure is not } \\
\text { operating as required by } \\
\text { code, what percentage of } \\
\text { buildings have necessary } \\
\text { hardware \& software to } \\
\text { meet code? }\end{array}$ & 100 & & N/A & 100 & 80 & 98 & $\begin{array}{l}100 \% \text { if } \\
\text { software is } \\
\text { there }\end{array}$ & 85 & 80 & 90 & $90 \%$ \\
\hline $\begin{array}{l}17.6 \text { What are the } \\
\text { common deficiencies } \\
\text { associated with this } \\
\text { measure? }\end{array}$ & $\begin{array}{l}\text { System hasn't } \\
\text { learned when } \\
\text { to start yet }\end{array}$ & $\begin{array}{l}\text { Not a Title } 24 \\
\text { requirement? }\end{array}$ & N/A & $\begin{array}{l}\text { Lack of } \\
\text { implement } \\
\text { ation, not } \\
\text { turned on }\end{array}$ & $\begin{array}{l}\text { Sensors, } \\
\text { locations, } \\
\text { weather link }\end{array}$ & $\begin{array}{l}\text { Programmin } \\
\mathrm{g}\end{array}$ & Fine tuning & $\begin{array}{l}\text { Difficult to } \\
\text { test, Must } \\
\text { trend with } \\
\text { occupancy. } \\
\text { Doesn't start } \\
\text { at proper } \\
\text { time }\end{array}$ & $\begin{array}{c}\text { Poor } \\
\text { sequnce or } \\
\text { programmin } \\
\text { g, adaptive } \\
\text { program } \\
\text { ineffective } \\
\text { initially }\end{array}$ & $\begin{array}{c}\text { Not } \\
\text { designed or } \\
\text { programmed }\end{array}$ & \\
\hline $\begin{array}{l}17.7 \text { What can be done to } \\
\text { help ensure this measure } \\
\text { is correctly implemented? }\end{array}$ & $\begin{array}{l}\text { Better control } \\
\text { sequence }\end{array}$ & $\begin{array}{l}\text { MEP does } \\
\text { not specify } \\
\text { sequence }\end{array}$ & & $\begin{array}{l}\text { Follow-up } \\
\text { with } \\
\text { trending }\end{array}$ & Same & & Better spec & $\begin{array}{l}\text { Good control } \\
\text { sequence }\end{array}$ & $\begin{array}{l}\text { Trend } \\
\text { occupied } \\
\text { mode }\end{array}$ & $\begin{array}{c}\text { MEP } \\
\text { education }\end{array}$ & \\
\hline
\end{tabular}




\begin{tabular}{|c|c|c|c|c|c|c|c|c|c|c|c|}
\hline Organization Location & Seattle, WA & $\begin{array}{c}\text { Sacramento } \\
\text { CA }\end{array}$ & $\begin{array}{c}\text { Gainesville } \\
\text { FL }\end{array}$ & Mesa AZ & Dallas TX & Seattle WA & Toronto ON & Denver CO & $\begin{array}{l}\text { Lexington } \\
\mathrm{KY}\end{array}$ & Austin TX & Avg \\
\hline $\begin{array}{l}\text { 18. In your opinion, do } \\
\text { construction documents } \\
\text { typically provide sufficient } \\
\text { information for successful } \\
\text { implementation of } \\
\text { controls for HVAC and } \\
\text { lighting systems? }\end{array}$ & No & No & $\begin{array}{c}\text { Pretty } \\
\text { decent, some } \\
\text { room for } \\
\text { improvement }\end{array}$ & $\begin{array}{c}\text { Yes for } \\
\text { general } \\
\text { intent, but } \\
\text { no for } \\
\text { certain } \\
\text { measures. } \\
\text { The more } \\
\text { detail on } \\
\text { sequences } \\
\text {, the } \\
\text { better. } \\
\text { MEP } \\
\text { doesn't } \\
\text { know how } \\
\text { to write } \\
\text { sequence, } \\
\text { and thus } \\
\text { sequences } \\
\text { are vague. }\end{array}$ & $\begin{array}{c}\text { No. Lack of } \\
\text { detail, poor } \\
\text { sequence, } \\
\text { no logic, }\end{array}$ & $\begin{array}{l}\text { Always need } \\
\text { to work with } \\
\text { MEP, } 24 \text { hrs } \\
\text { per project }\end{array}$ & $\begin{array}{l}\text { Varies, } \\
\text { depend on } \\
\text { designers, } \\
\text { from very } \\
\text { good to } \\
\text { none }\end{array}$ & $\begin{array}{l}\text { Specs Lacks } \\
\text { SetPts or } \\
\text { Schedules, } \\
\text { Factory } \\
\text { control } \\
\text { sequence is } \\
\text { not included } \\
\text { in submittals }\end{array}$ & $\begin{array}{l}\text { Specs Lacks } \\
\text { SetPts or } \\
\text { Schedules }\end{array}$ & $\begin{array}{l}\text { No, lack of } \\
\text { education }\end{array}$ & \\
\hline $\begin{array}{l}\text { 19. In your opinion, do } \\
\text { control contractors } \\
\text { generally meet all control } \\
\text { sequence requirements } \\
\text { specified in the } \\
\text { construction documents? }\end{array}$ & Yes & Yes & $\begin{array}{l}\text { In general } \\
\text { they do, but } \\
\text { only work } \\
\text { half the time } \\
\text { for some } \\
\text { things }\end{array}$ & $\begin{array}{l}\text { Yes, they'll } \\
\text { try to meet } \\
\text { sequence } \\
\text { intent, but } \\
\text { often need } \\
\text { help. }\end{array}$ & $\begin{array}{c}\text { Absolutely } \\
\text { not }\end{array}$ & $\begin{array}{l}\text { No, but } \\
\text { eventually } \\
\text { get it right }\end{array}$ & $\begin{array}{l}\text { Yes, } \\
\text { provided } \\
\text { they are } \\
\text { verified by } \\
\text { CxA or } \\
\text { others }\end{array}$ & $\begin{array}{l}\text { Depends on } \\
\text { the controls } \\
\text { tech, great } \\
\text { variety in } \\
\text { ability }\end{array}$ & No & $\begin{array}{c}\text { No, When } \\
\text { called to task } \\
\text { they make it } \\
\text { work }\end{array}$ & \\
\hline $\begin{array}{l}\text { 20. Approximately what } \\
\text { percent of the time do } \\
\text { you find control } \\
\text { contractors include these } \\
\text { measures in their } \\
\text { installation if not required } \\
\text { by the construction } \\
\text { documents? }\end{array}$ & $\begin{array}{l}\text { Maybe } 10 \% \text { of } \\
\text { the time }\end{array}$ & $\begin{array}{l}\text { 90, that's why } \\
\text { we have Cx }\end{array}$ & $\begin{array}{c}\text { Maybe } 10 \% \text {, } \\
\text { if they know } \\
\text { owner }\end{array}$ & $50 \%$ & $\begin{array}{l}90 \text { needed } \\
\text { to make } \\
\text { systems } \\
\text { work }\end{array}$ & $60 \%$ & Zero & $\begin{array}{l}65 \%, \text { MEP } \\
\text { don't } \\
\text { understand } \\
\text { required } \\
\text { elements for } \\
\text { control } \\
\text { sequences }\end{array}$ & Zero & Zero & \\
\hline
\end{tabular}




\begin{tabular}{|c|c|c|c|c|c|c|c|c|c|c|c|}
\hline Organization Location & Seattle, WA & $\begin{array}{l}\text { Sacramento } \\
\text { CA }\end{array}$ & $\begin{array}{c}\text { Gainesville } \\
\text { FL }\end{array}$ & Mesa AZ & Dallas TX & Seattle WA & Toronto ON & Denver CO & $\begin{array}{l}\text { Lexington } \\
\mathrm{KY}\end{array}$ & Austin TX & Avg \\
\hline $\begin{array}{l}21 . \text { In your opinion, what } \\
\text { is the greatest } \\
\text { impediment or necessary } \\
\text { addition, for successful } \\
\text { implementation of code- } \\
\text { required controls? }\end{array}$ & $\begin{array}{l}\text { Better training } \\
\text { of MEPs and } \\
\text { contractors }\end{array}$ & $\begin{array}{l}\text { Not } \\
\text { understandin } \\
\text { g code }\end{array}$ & $\begin{array}{l}\text { Get the word } \\
\text { out, more } \\
\text { training }\end{array}$ & $\begin{array}{c}\text { More } \\
\text { clarification } \\
\text { in design } \\
\text { sequences } \\
\text {. With Title } \\
24 \text {, is it } \\
\text { better or } \\
\text { worse? } \\
\text { Requires } \\
\text { design } \\
\text { team } \\
\text { meeting, } \\
\text { not done in } \\
\text { Arizona. } \\
\text { CA } \\
\text { installers } \\
\text { must } \\
\text { certify } \\
\text { testing and } \\
\text { be } \\
\text { certified. } \\
\text { Better } \\
\text { trained } \\
\text { contractors } \\
\text { in CA and } \\
\text { better } \\
\text { efficiency. }\end{array}$ & $\begin{array}{l}\text { Training, } \\
\text { Stop } \\
\text { changing the } \\
\text { requirement } \\
\text { s so often, }\end{array}$ & $\begin{array}{l}\text { Inspectors } \\
\text { Ask for } \\
\text { documentati } \\
\text { on, } \\
\text { contractors } \\
\text { comply }\end{array}$ & $\begin{array}{c}\text { Education of } \\
\text { design } \\
\text { community, } \\
\text { Round table } \\
\text { explanation } \\
\text { of design } \\
\text { intent, Good } \\
\text { Cx. }\end{array}$ & $\begin{array}{l}\text { Lack of } \\
\text { well-defined } \\
\text { sequences. } \\
\text { Simplifying } \\
\text { codes, } \\
\text { energy } \\
\text { intensity } \\
\text { approach } \\
\text { (do LED } \\
\text { systems } \\
\text { need } \\
\text { daylight } \\
\text { controls?), } \\
\text { Requirement } \\
\text { s by room } \\
\text { types is } \\
\text { difficult } \\
\text { because } \\
\text { designers } \\
\text { don't use } \\
\text { standard } \\
\text { room } \\
\text { names. } \\
\text { Need } \\
\text { sequence for } \\
\text { each space. }\end{array}$ & $\begin{array}{c}\text { Delineation } \\
\text { of lines of } \\
\text { responsibility } \\
\text {, MEP is } \\
\text { responsible } \\
\text { for proper } \\
\text { design for } \\
\text { code } \\
\text { compliance, } \\
\text { CXA should } \\
\text { focus on CD } \\
\text { requirement } \\
\text { S, Improper } \\
\text { training of } \\
\text { AHJs, 3rd } \\
\text { party CXA } \\
\text { should not } \\
\text { referee } \\
\text { between } \\
\text { MEPs and } \\
\text { AHJs. }\end{array}$ & $\begin{array}{l}\text { Important } \\
\text { issue is to } \\
\text { educate the } \\
\text { owner as to } \\
\text { why it's } \\
\text { important, } \\
\text { people want } \\
\text { simplicity, } \\
\text { people } \\
\text { should have } \\
\text { an individual } \\
\text { HVAC unit, }\end{array}$ & \\
\hline
\end{tabular}


Appendix C

Statistical Analysis Details 


\section{Appendix C}

\section{Statistical Analysis Details}

\section{C.1 Statistical Validation of Compliance Results}

This appendix explains in more detail the statistical analyses of the field results summarized in Sections 5.1 and 5.2. So this appendix may stand alone as a document, some tables that were included in the main report are repeated here.

Several statistical analyses were conducted to determine whether the pilot results could be reliably used as the basis for program actions. The field survey collected score data for 14 measures in 24 buildings. Many of the measures only applied in some of the buildings; consequently, measure by measure data sometimes resulted in relatively small samples; therefore, it is important to know which results are likely to be repeated in a larger sample and which are inconclusive. Statistical analysis can account for the combination of sample size and the average differences in results for different measures or groups of measures. Where statistical analysis shows a high level of significance based on the data collected, it is reasonable to assume that the current results and conclusions are representative of what would be seen in a larger population of buildings. When the level of significance is moderate or marginal, the results should not be assumed to apply more broadly. For example, thermostat setback is shown to have low configured compliance with a high level of significance. This indicates that that it would be reasonable to use the current results as a basis for actions targeted at improving compliance. On the other hand, while exterior lighting controls clearly could be improved, the statistical results were not even marginally significant, meaning they should not be used to guide program efforts.

Because the samples in general are skewed to the high and low score and do not have a normal distribution, a robust non-parametric paired Mann-Whitney U test (aka Wilcoxon rank sum test) was used rather than a simple parametric t-test (Mann and Whitney 1947). The test calculates an estimate of the pvalue or probability of the null hypothesis. The p-value indicates the level of significance, as shown in Table C.1. Some may choose a standard p-value as a constant limit for significance; however, given the relative small sample size, differentiating the levels of significance and certainty relative to the tested hypothesis can be helpful to understanding the relative impact of results. Again, highly significant findings can be acted on immediately, while marginally significant findings may warrant further research. 
Table C.1. Meaning of p-value and Levels of Significance and Certainty

\begin{tabular}{llllcc}
\hline \multicolumn{1}{c}{ p-value } & Indicator & Tag & Significance & $\begin{array}{c}\text { Probability } \\
\text { of error }\end{array}$ & $\begin{array}{c}\text { Certainty of } \\
\text { conclusion }\end{array}$ \\
\hline $\mathrm{p}<0.001$ & Bold & $* * *$ & Highly significant difference & $0.1 \%$ & $99.9 \%$ \\
$0.001 \leq \mathrm{p}<0.01$ & Bold & $* *$ & & $1 \%$ & $99 \%$ \\
$0.01 \leq \mathrm{p}<0.05$ & Bold Ital & $*$ & Significant difference & $5 \%$ & $95 \%$ \\
$0.05 \leq \mathrm{p}<0.1$ & Normal & $\cdot$ & Moderately Significant difference & $10 \%$ & $90 \%$ \\
$0.1 \leq \mathrm{p}<0.2$ & Norm Ital & $\sim$ & Marginally significant difference & $20 \%$ & $80 \%$ \\
$0.2 \leq \mathrm{p}$ & Grey & & No significant difference & $>20 \%$ & Not \\
\hline
\end{tabular}

When comparing scores based on more than two factors, a multiple comparison test after KruskalWallis was conducted (Siegel and Castellan 1988). Rather than giving a p-value directly, this test simply shows true or false (meaningful difference or no meaningful difference) at an input p-value. Incremental runs are conducted to locate a relative significance level. The Kruskal-Wallis test is non-parametric and suitable for skewed (non-normal distribution) data like the score results in this control field study. To validate that the measure scores overall are indeed different from a fully compliant application, each measure was compared to the DCV measure that had 17 observations, all of which were fully compliant with the energy code. Most of the control measures investigated are shown to be significantly lower than the perfect scoring DCV measure (***, $\mathrm{p}<0.001$; $\left.{ }^{* *}, \mathrm{p}<0.01 ; *, \mathrm{p}<0.05\right)$. Static pressure reset is moderately significant $(\mathrm{p}<0.1)$. The exceptions found not significantly different from full compliance were exterior lighting control, zone isolation (only single site), and supply air temperature reset. For the more significant measure results, this suggests that similar levels of compliance will occur in a larger population of buildings. If individual measure results are desired for the non-significant or marginally significant measures, a future study should be designed with a larger measure sample to better determine measure compliance rates.

\section{C.1.1 Code Compliance of Control Measures}

Understanding which control measures are not in full compliance with code helps focus the development of code user's manuals, designer or code official training materials, and contractor or industry education programs. Table C.2 shows the scores by measure for the final configuration perspective. The minimum, average and maximum scores are shown, along with the number of field observations and score standard deviations. High standard deviations of the score indicate a large variability from site to site and the highest four standard deviations are bolded, as the variability may indicate a need to focus on these measures in future training or compliance activities.

To validate that the measure scores overall are indeed different from a fully compliant application, each measure was compared to the DCV measure that had 17 observations, all of which were fully compliant with the energy code. Most of the control measures investigated are shown to be significantly lower than the perfect scoring DCV measure (***, $\mathrm{p}<0.001 ; * *, \mathrm{p}<0.01 ; *, \mathrm{p}<0.05)$. Static pressure reset is moderately significant $(\mathrm{p}<0.1)$. The exceptions found not significantly different from full compliance were exterior lighting control, zone isolation (only a single site), and supply air temperature reset. For the more significant measure results, this suggests that similar levels of compliance will occur in a larger population of buildings. If individual measure results are desired for the non-significant or marginally 
significant measures, a future study should be designed with a larger measure sample to better determine measure compliance rates.

Table C.2. Measure Compliance Scores and Statistical Significance ${ }^{\dagger}$

\begin{tabular}{|c|c|c|c|c|c|c|c|}
\hline & \multicolumn{4}{|c|}{ Scores at Configuration Perspective } & \multirow[b]{2}{*}{$\begin{array}{l}\text { Observa- } \\
\text { tions }\end{array}$} & \multirow[b]{2}{*}{$\begin{array}{c}\text { P-value vs. DCV } \\
\text { (perfect compliance) }\end{array}$} & \multirow[b]{2}{*}{$\begin{array}{l}\text { Signif- } \\
\text { icance }\end{array}$} \\
\hline & Minimum & Average & Maximum & $\begin{array}{c}\text { Standard } \\
\text { Deviation }\end{array}$ & & & \\
\hline \multicolumn{8}{|c|}{ HVAC Measures: } \\
\hline TstatDdBnd & 4.00 & 8.09 & 10.00 & 2.0 & 24 & 0.0019 & ** \\
\hline EconoInt & 0.00 & 7.46 & 10.00 & 2.9 & 24 & 0.0019 & $* *$ \\
\hline TstatSetbk & 0.00 & 6.02 & 10.00 & 3.6 & 24 & 0.0005 & $* * *$ \\
\hline SimultHtCl & 1.50 & 7.91 & 10.00 & 2.8 & 10 & 0.0178 & $*$ \\
\hline AutoDamp & 0.00 & 4.00 & 10.00 & 4.4 & 10 & 0.0131 & * \\
\hline SAT-Reset & 1.00 & 9.10 & 10.00 & 2.7 & 10 & 0.50000 & \\
\hline ZoneIso & 3.30 & 3.30 & 3.30 & 0.0 & 1 & N/A & \\
\hline DCV & 10.00 & 10.00 & 10.00 & 0.0 & 17 & N/A & \\
\hline SP-Reset & 0.00 & 7.90 & 10.00 & 3.2 & 10 & 0.0502 & . \\
\hline OptStart & 0.00 & 3.75 & 10.00 & 4.8 & 24 & 0.0003 & $* * *$ \\
\hline \multicolumn{8}{|c|}{ Lighting Measures: } \\
\hline OccSenLtg & 4.33 & 9.00 & 10.00 & 1.5 & 24 & 0.0108 & $*$ \\
\hline DayLtgCtl & 0.00 & 6.59 & 10.00 & 4.2 & 22 & 0.0018 & $* *$ \\
\hline ExtLtgCtl & 9.05 & 9.94 & 10.00 & 0.2 & 24 & 0.5000 & \\
\hline IntLtgCtl & 0.00 & 8.77 & 10.00 & 2.8 & 23 & 0.0131 & $*$ \\
\hline
\end{tabular}

$\dagger$ Formatting and tags to indicate significance level are shown in Table C.1.

\section{C.2 Relationships of Perspectives and Time Lag}

Comparing the design, capability, and configuration scores offers insights that cannot be found by looking at each score in isolation. In some cases, there is also an impact of the time lag from when the building is occupied to when field audit is conducted.

- If design and configuration scores are the same, then it may be possible to determine energy code compliance just by reviewing the plan submittal without visiting the building.

- If capability scores are significantly higher than design scores, it may indicate that product manufacturers or contractors are aware of code provisions, and provide equipment that is capable of meeting code, even if not specifically called out in design documents.

- If capability scores are significantly lower than design scores it may indicate a need for better training of controls contractors, enhanced commissioning, or both. A review of the detailed site results found that only occupancy sensor control in Retail A had a lower capability score than design.

- If configured scores are significantly lower than capability scores, it may indicate that there is not a concerted effort either in the design, installation or commissioning work to specifically call out setpoints, schedules or other subtle code requirements. There may also be cases where, due to a 
time lag from installation/occupancy and the field audit, building occupants or managers have changed the setpoints. Some may even argue that the code only requires capability of controls rather than proper configuration. Recent code change efforts (90.1-2016 and 2018 IECC) have added the words "configured to" where control provisions call for certain setpoints; however these updated codes were not in effect for the buildings in this field study.

- If there is a strong impact of time lag between occupancy and the field audit, then future studies may want to more strictly manage this time lag.

\section{C.2.1 Overall Relationship between Perspectives}

The overall relationship between the perspectives (design, capability, and configuration) measured is shown in Table 9 on a group basis. The group average score is shown for each perspective and the differences between perspective average scores is shown. A multiple comparison test after Kruskal-Wallis is conducted with incremental thresholds of $\mathrm{p}<0.2$ and $\mathrm{p}<0.1$ to find the significance of the differences in perspective group average scores.

As can be seen in Table C.3, the overall scores at the design and configuration perspective are not significantly different for HVAC and measures as a whole. The lighting measures are different from design to configuration. The capability scores are significantly different from scores for both the design and configuration perspectives, except for lighting. This may indicate that:

- Configured compliance might be inferred on average overall or for HVAC measures based on review of design documents. A deeper analysis will review this idea when individual measures are reviewed in Section 1.1.1.

- Manufacturers and contractors are aware of code provisions not specifically called out in design documents and provide most equipment with the capability of meeting code, as the capability group scores are all higher than the design scores.

- Building controls are not configured to meet code requirements in many cases, or have been reconfigured during building occupancy after project completion. Since controls are generally capable of achieving a higher compliance score than is actually achieved, more specific design detail around setpoint requirements or contractor and building manager training may result in higher configured scores.

- Building controls can benefit from post-occupancy building tuning or recommissioning efforts aimed at improving energy efficiency of the building, since the configured scores are lower than the capability. 
Table C.3. Difference in Perspective Average Compliance Scores

\begin{tabular}{lcccccc}
\hline & \multicolumn{2}{c}{ Group Compliance Average Scores } & \multicolumn{3}{c}{ Perspective Differences in Scores } \\
Group & Design & Capability & Configuration & Design to & $\begin{array}{c}\text { Design to } \\
\text { Configuration }\end{array}$ & $\begin{array}{c}\text { Capability to } \\
\text { Configuration }\end{array}$ \\
\hline All Measures & 7.22 & 9.46 & 7.58 & +0.36 & $\mathbf{+ 2 . 2 4}$ & $\mathbf{- 1 . 8 8}$ \\
HVAC & 6.80 & 9.64 & 6.95 & +0.15 & $\mathbf{+ 2 . 8 3}$ & $\mathbf{- 2 . 6 9}$ \\
Lighting & 7.91 & 9.16 & 8.61 & $\mathbf{+ 0 . 7 1}$ & $\mathbf{+ 1 . 2 6}$ & -0.55 \\
\hline
\end{tabular}

$\dagger$ Boldface indicates that the difference between perspectives is at least moderately significant at $\mathrm{p}<0.1$, while a grey score difference is not significantly different, $\mathrm{p}>0.2$.

\section{C.2.2 Control Measures Compliance Variation by Perspective}

Overall, the preceding analyses showed that configuration is generally better than design compliance and that configuration is lower than capability. However, individual measures may show differences from the overall trend. Understanding the perspective differences of individual measures will allow remediation activities to be better targeted. The data in Table C. 4 can provide observations about how different measures are implemented relative to code requirements. The average scores by measure are shown for each perspective, then the difference between perspective scores is shown. The p-values to indicate the significance of those differences is shown, based on a robust a non-parametric paired MannWhitney U test (Mann and Whitney 1947). 
Table C.4. Difference in Perspective - Measure-by-Measure Compliance Scores

\begin{tabular}{|c|c|c|c|c|c|c|c|c|c|}
\hline \multirow[b]{2}{*}{ Measure } & \multicolumn{3}{|c|}{$\begin{array}{l}\text { Measure Average } \\
\text { Compliance Scores }\end{array}$} & \multicolumn{3}{|c|}{$\begin{array}{c}\text { Perspective Differences in } \\
\text { Scores }\end{array}$} & \multicolumn{3}{|c|}{$\begin{array}{l}\text { Probability of Non-difference (p-value) } \\
\text { Bold = significant; } p \text {-value }<0.05^{\dagger}\end{array}$} \\
\hline & Design & Cap & Config, & $\begin{array}{c}\text { Design } \\
\text { to } \\
\text { Config, }\end{array}$ & $\begin{array}{l}\text { Design to } \\
\text { Cap }\end{array}$ & $\begin{array}{l}\text { Capability } \\
\text { to Config, }\end{array}$ & $\begin{array}{l}\text { Design to } \\
\text { Config, }\end{array}$ & $\begin{array}{l}\text { Design to } \\
\text { Cap }\end{array}$ & $\begin{array}{l}\text { Cap to } \\
\text { Config, }\end{array}$ \\
\hline \multicolumn{10}{|c|}{ HVAC Measures: } \\
\hline TstatDdBnd & 5.6 & 10.0 & 8.1 & +2.48 & +4.39 & -1.91 & $0.0117 *$ & $0.0003 * * *$ & $0.0002 * *$ \\
\hline EconoInt & 7.1 & 8.5 & 7.5 & +0.37 & +1.37 & -1.00 & $0.0227 *$ & $0.0003 * * *$ & $0.0012 * *$ \\
\hline TstatSetbk & 6.0 & 9.8 & 6.0 & +0.04 & +3.85 & -3.81 & 0.4360 & $0.0002 * * *$ & $0.0001 * * *$ \\
\hline SimultHtCl & 8.7 & 10.0 & 7.9 & -0.82 & +1.28 & -2.09 & 0.2948 & $0.0110 *$ & $0.0111 *$ \\
\hline AutoDamp & 5.5 & 9.5 & 4.0 & -1.50 & +4.00 & -5.50 & 0.2439 & $0.0267 *$ & $0.0096 * *$ \\
\hline SAT_Reset & 9.0 & 10.0 & 9.1 & +0.10 & +1.00 & -0.90 & 0.5000 & 0.5000 & 0.5000 \\
\hline ZoneIso & 0.0 & 10.0 & 3.3 & +3.30 & +10.00 & -6.70 & $\mathrm{n} / \mathrm{a}^{\dagger \dagger}$ & $\mathrm{n} / \mathrm{a}^{\dagger \dagger}$ & $\mathrm{n} / \mathrm{a}^{\dagger+}$ \\
\hline DCV & 10.0 & 10.0 & 10.0 & 0.00 & 0.00 & 0.00 & $\mathrm{n} / \mathrm{a}^{\dagger \dagger}$ & $\mathrm{n} / \mathrm{a}^{\dagger \dagger}$ & $\mathrm{n} / \mathrm{a}^{\dagger \dagger}$ \\
\hline SP_Reset & 7.7 & 10.0 & 7.9 & +0.20 & +2.30 & -2.10 & 0.4661 & $0.0267 *$ & 0.0502 \\
\hline OptStart & 5.0 & 9.6 & 3.8 & -1.25 & +4.58 & -5.83 & $0.1753 \sim$ & $0.0005 * *$ & $0.0001 * * *$ \\
\hline \multicolumn{10}{|c|}{ Lighting Measures: } \\
\hline OccSenLtg & 8.4 & 9.3 & 9.0 & +0.59 & +0.85 & -0.26 & 0.0043 & $0.0015 * *$ & $0.0089 * *$ \\
\hline DayLtgCtl & 7.2 & 8.5 & 6.6 & -0.63 & +1.25 & -1.88 & 0.5000 & $0.0057 * *$ & $0.0029 * *$ \\
\hline ExtLtgCtl & 7.5 & 10.0 & 9.9 & +2.42 & +2.50 & -0.08 & $0.0187 *$ & $0.0098 * *$ & 0.0868 \\
\hline IntLtgCtl & 8.5 & 8.9 & 8.8 & +0.30 & +0.39 & -0.08 & $0.1348 \sim$ & 0.0672 & 0.5000 \\
\hline
\end{tabular}

$\dagger \quad$ Formatting and tags to indicate significance level is described in Table C.1.

$\dagger^{\dagger}$ The significance of the difference in perspective scores could not be calculated; DCV received a perfect score at all sites for all perspectives, so there was no difference; zone isolation only had one case.

Reviewing the data in Table C4, we have the following observations in areas of interest.

- For the HVAC measures that had a significant difference from the design to configured score, the two with a clearly significant difference (thermostat deadband and economizer control) both had better scores at configuration. Optimum start had a lower average score for configuration vs. design, but the difference is only marginally significant.

- With the exception of daylighting, the configured lighting controls were more likely to meet code described sequences than the design, indicating that lighting contractors have a good understanding of the basic lighting control requirements.

- The fact that for daylighting, both the design and configured score were significantly worse than the capability perspective, indicates that improving the daylighting impact will take effort both with designers and contractors.

- For most measures (excluding supply air temperature reset, zone isolation, and demand controlled ventilation) the difference between design and capability was positive and significant. In no case was the measure capability average score below the average design score. This indicates that suppliers, contractors, and/or commissioning agents are implementing control capability when required by code, even when not explicitly included in the design. 
- The drop in score from capable to configured was significant or marginally significant in all cases except supply air temperature reset, DCV, and interior lighting time control (Zone isolation is excluded with only one observation). Actual configuration would likely benefit from more specific setpoint or sequence guidance in design documents or commissioning agents having a clearer mandate to configure controls to match the setpoints called for in code. It could also indicate building operators are disabling code-specified sequences after occupancy indicating either a design flaw (comfort issues) or lack of understanding of the control sequence energy benefit on the part of building operators. Both of these possibilities could be addressed through training of the appropriate party.

- Building controls can benefit from building tuning or recommissioning efforts that are specifically aimed at improving energy efficiency of the building.

\section{C.2.2.1 Using Design Compliance as a Proxy for Configured Compliance}

One of the open questions related to reducing the costs of compliance studies is whether overall compliance can be determined based on a review of design documents without field verification? This would obviously reduce the cost of commercial compliance studies. The review of results so far has been targeted at discovering the significance of differences between measures and groups of measures and different perspectives. For smaller sample sizes like those in this study, determining that the difference in sample averages is not significant does not prove that the sample averages are equivalent. However, equivalence analysis can be used to see if two results are equivalent within desired parameters, just as one might evaluate a generic drug's equivalence to a brand name prescription. Evaluating the compliance scores from the design and configuration perspective with a robust two one sided test (rtost) can determine if they are significantly equivalent, which is not the same as being "not significantly different" (Robinson 2016).

The overall score results from the entire study for all measures was evaluated for equivalence. The purpose is to see if design compliance is a good indicator of overall building configuration compliance. The term equivalent is not used here in the strict sense, but rather to mean that the compliance scores of the two perspectives are close enough so that one cannot be considered superior or inferior to the other. This concept is formalized in the definition of a constant called the equivalence margin. The equivalence margin defines a range of values for which the scores are "close enough" to be considered equivalent. In practical terms, the margin is the maximum acceptable difference that one is willing to accept in return for the lower costs of the evaluation. Based on an equivalence margin of \pm 1.0 points in compliance score, the overall design vs. configured results were found to be significantly the same at the $\mathrm{p}<0.05$ level ( $\mathrm{p}=0.016$ and confidence level $=0.968$ ). So if the only interest in a compliance study were to find if control measures were in compliance within a score range of $\pm 10 \%$, then it is possible to determine a compliance rating for the building overall—not individual measures—just from design document review. However, if a tighter score range ( \pm 0.5 or $\pm 5 \%$ ) was desired, the overall scores would not be considered significantly equivalent.

To further review the possibility of projecting configured compliance from an evaluation of design, measure level results, such as those show in Table C.4can be reviewed. To give a better picture of the distribution of actual results, the individual differences between design and configured compliance scores are plotted in . The results are grouped by measure, with a small offset for each building so the overall distribution can be viewed. All the points for each measure are between the gridlines. A zero difference in 
Figure C.1 indicates the same compliance score for both design and configured perspectives; a positive difference indicates design is higher and a negative difference indicates the configured condition is scored better than design. One interesting example is thermostat setback (measure 9), which has an average score in Table C.4 of 6.0 for both design and configured with the least difference of all the measures except DCV at +0.04 . Reviewing the measure (9) in Figure C.1 we can see that even though the score has almost identical averages for both perspectives, individual building score differences vary widely.

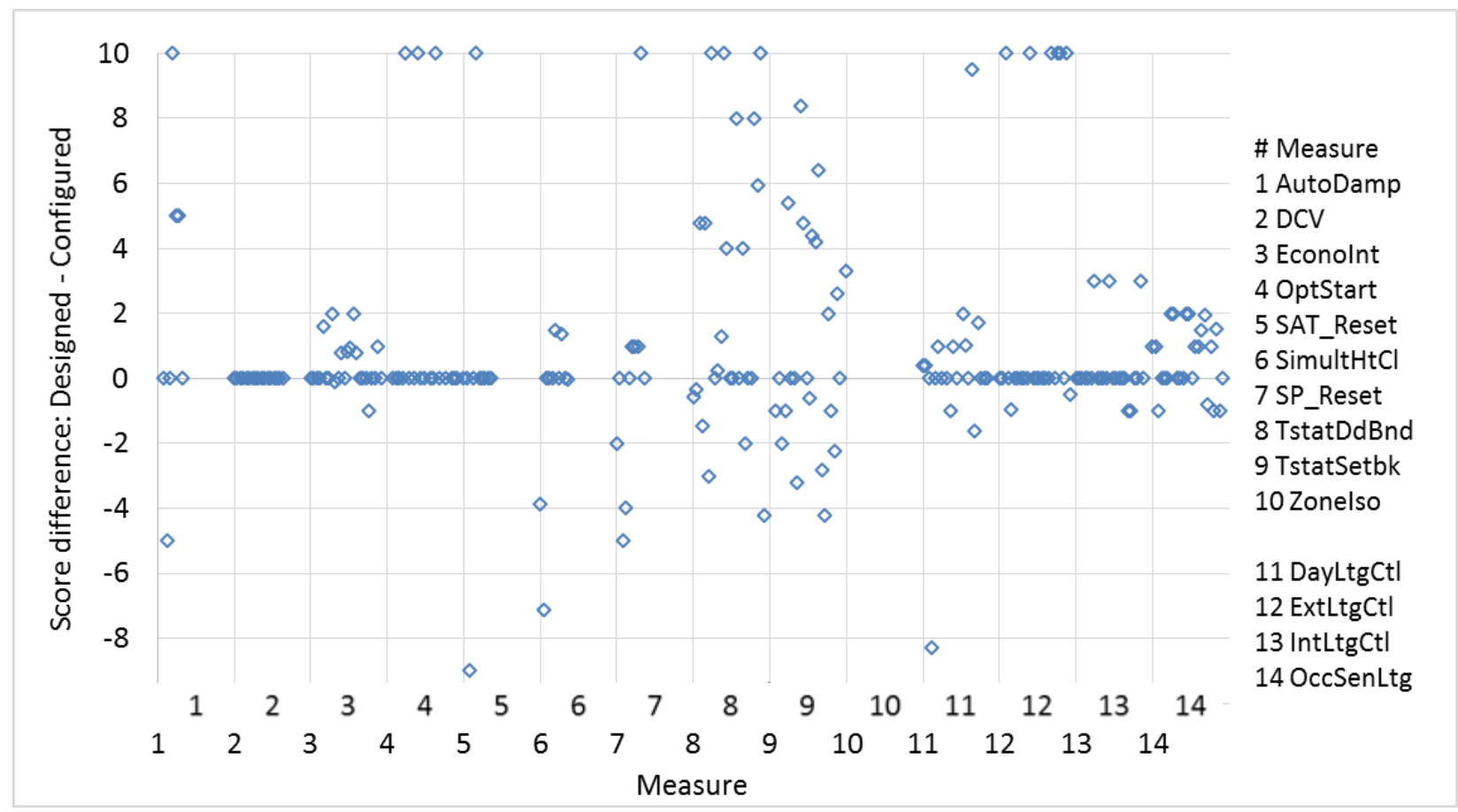

Figure C.1. Measure Score Difference between Design and Configured Perspective

To understand the score relationship between design and configured perspectives, we can apply an equivalency analysis like we did to the full sample of all observations. Measures were reviewed for equivalence using the same robust statistical equivalence test. When each of the measures are evaluated for equivalence with a specification of significance level at $\mathrm{p}<0.05$ and the magnitude of the similarity region at \pm 1.0 points ( $\pm 10 \%$ ), only DCV, economizer and interior lighting control were found to be significantly similar. Figure C.1, shows a lack of extreme differences for these measures (\# 2, 3, \& 13).

Based on the analysis of this limited sample, it can be concluded that final configuration compliance cannot be inferred on a measure specific basis from the design perspective compliance, at least not for most control measures. It may be possible to infer overall building control compliance based on design score, but it would take a much larger sample to verify that approach for a particular mix of measures. Seeing the difference in perspective compliance can help direct training or enforcement activities where they will have the most benefit. Overall, conclusions related to using design scores as a proxy for final compliance are:

- It appears that design can be used as a proxy for configuration scores overall given a $\pm 10 \%$ equivalence band in scores. 
- Generally, there are significant, if small, increases between design and configuration scores on most measures. In no cases are reductions in score from design to configuration found to be significant, as shown in Table C.4.

\section{C.2.3 The Impact of Time Lag on Configured Results}

Configured conditions could be affected by changes made between the time the building was occupied and the audit completed. As discussed in Section 1.1.1 the energy code compliance process typically ends once a jurisdiction issues a certificate of occupancy. Therefore if judgements of compliance are to be made it needs to be determined if site assessments conducted up to two years after occupancy are a good indicator of measure condition at the time the building was first occupied. The audit lag in this study ranged from -1 month (inspected just before occupancy) to 27 months after occupancy, with a median of 4 months and an average of 7 months.

An analysis was made by dividing the buildings into groups based on lag time from occupancy to audit. Short, Medium, and Long lag groups were established based on the time in months from occupancy to field audit as shown in Table C.5, Half the sample was in the short group with a quarter each in the medium and long groups. A multiple comparison test after Kruskal-Wallis was conducted with iterative thresholds to verify significance. The test showed that there was an increase in differential score with increasing lag, with a marginally significant difference in average score from the short lag group to the long lag group of 0.94 points. The average score changes are shown by measure group in Figure C.2.

Table C.5. Impact of Audit Lag on Capable to Configured Scores ${ }^{\dagger}$

\begin{tabular}{|c|c|c|c|c|c|}
\hline $\begin{array}{l}\text { Lag } \\
\text { Group }\end{array}$ & $\begin{array}{c}\text { Months } \\
\text { Lag }\end{array}$ & $\begin{array}{l}\text { Average } \\
\text { Building } \\
\text { Mo. Lag } \\
\end{array}$ & $\begin{array}{c}\mathrm{n}, \\
\text { Buildings }\end{array}$ & $\begin{array}{c}n, \\
\text { measure } x \\
\text { site }\end{array}$ & $\begin{array}{r}\text { Average Score } \\
\text { Change, Capable to } \\
\text { Configured }\end{array}$ \\
\hline Short & $<4$ & 1.4 & 12 & 117 & -1.57 \\
\hline Medium & 4 to 10 & 7.6 & 6 & 59 & -1.75 \\
\hline Long & $>10$ & 16.1 & 6 & 71 & -2.50 \\
\hline All & & 6.6 & 24 & 247 & -1.88 \\
\hline \multicolumn{2}{|c|}{ Compare Lag Groups } & \multicolumn{4}{|c|}{ Difference in Score Change } \\
\hline \multicolumn{2}{|c|}{ Short to Medium } & \multicolumn{3}{|c|}{ No significant difference $p<0.2$} & -0.18 \\
\hline \multicolumn{2}{|c|}{ Short to Long } & \multicolumn{3}{|c|}{ Marginally Sig. difference $p<0.2$} & -0.94 \\
\hline \multicolumn{2}{|c|}{ Medium to Long } & No sig & ificant diff & ence $p<0.2$ & -0.75 \\
\hline
\end{tabular}




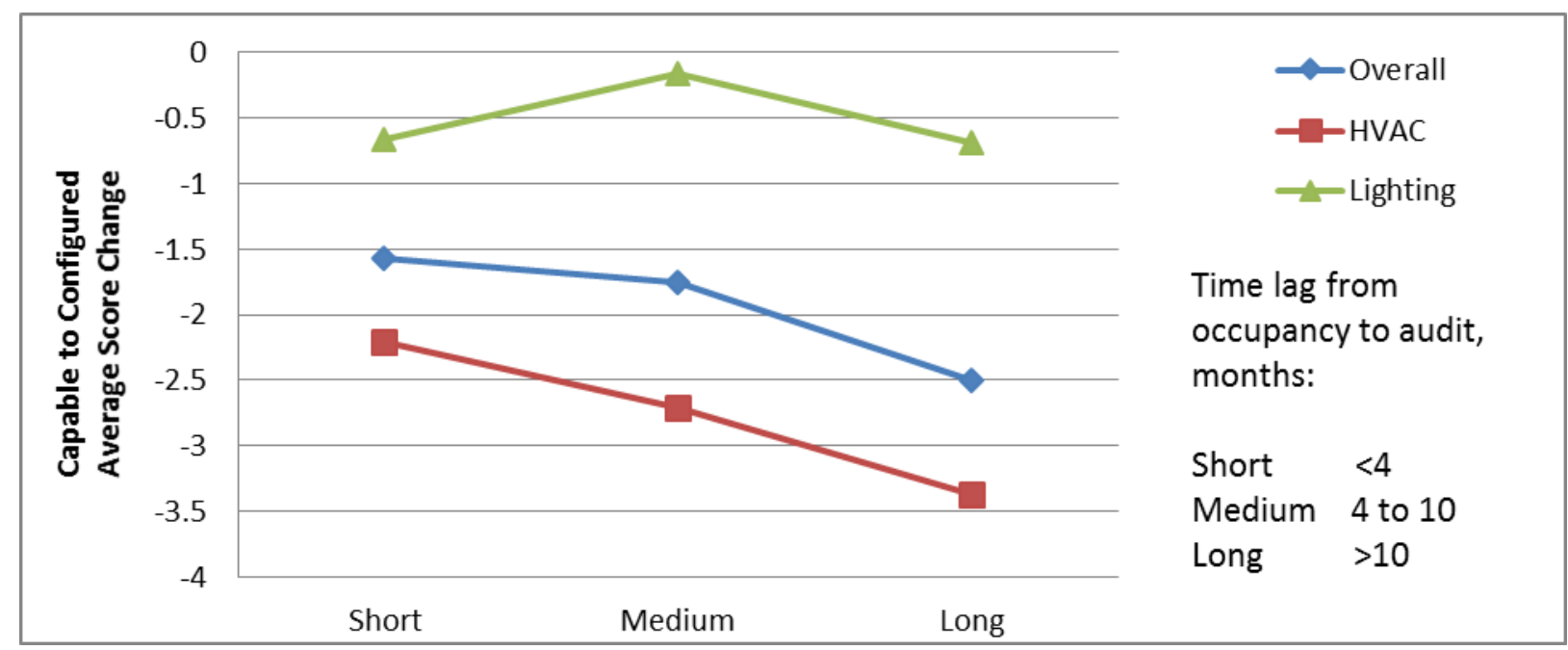

Figure C.2. Impact of Time Lag on Average Measure Score Difference

Since no significant difference was found overall from the short to medium group, this indicates that keeping the field audits within 10 months of occupancy is desirable. Since half of the long lag group here had a lag much longer than a year, extending that threshold out to 12 months is probably reasonable.

\section{C.3 Impact of Commissioning}

The impact of commissioning on compliance has been investigated for lighting and HVAC controls as groups and for individual measures.

\section{C.3.1 Overall Impact of Lighting and HVAC Commissioning}

For all the buildings, evidence of commissioning for lighting and HVAC was collected and the building flagged for commissioning by system. The impact of commissioning on configured perspective measure scores can only be evaluated for those measures that were present in both commissioned and non-commissioned buildings. Some HVAC measures were always commissioned and therefore were not included in this evaluation. There were no lighting measures that were always commissioned. The number of measures and their average configured scores are shown by group in Table C.6. The results were tested and the impact of HVAC commissioning on the measures was found to be marginally significant, while the impact of lighting commissioning was not found significant.

Table C.6. Overall Commissioning Impact, Kruskal-Wallis Multiple Comparison Test ${ }^{\dagger}$

\begin{tabular}{lccccccl}
\hline & \multicolumn{2}{c}{ Sample size, $\mathbf{n}$} & \multicolumn{2}{c}{$\begin{array}{c}\text { Average of Configured } \\
\text { Measure Scores }\end{array}$} & \multicolumn{2}{c}{ Pass Test } \\
Area & No Cx & Cx & No $\mathbf{C x}$ & $\mathbf{C x}$ & Delta & $(\mathrm{p}<0.2)$ & Conclusion \\
\hline HVAC & 24 & 99 & 5.74 & 6.87 & +1.13 & TRUE & Marginally significant at $p<0.2$ \\
Lighting & 26 & 67 & 8.30 & 8.73 & +0.43 & FALSE & Difference not significant \\
\hline
\end{tabular}

$\dagger$ Formatting to indicate significance level is shown in Table C.1. 


\section{C.3.2 Measure Level Impact of Commissioning}

A further analysis of commissioning impact was conducted at the measure level. The results are shown in Table C.7. Again, only HVAC measures which included non-commissioned buildings were included. Due to the sample size at the measure level, only two measures (automatic outside air dampers and occupancy sensor lighting) are found significant, while two measures (thermostat setback and optimum start) are found marginally significant. The impact of commissioning on DCV could not be verified, since DCV received a perfect score at all applicable sites. So, while HVAC commissioning was found to have a significant impact overall, it was not impactful on every measure. It may be that improved design specifications around setpoints required by code will increase the attention of commissioning agents to these measures. This is supported by the previously discussed feedback received from commissioning agents that code-required measures were not commissioned unless included in the design.

Table C.7. Commissioning Impact on Measures, Wilcoxon Rank Sum Test ${ }^{\dagger}$

\begin{tabular}{|c|c|c|c|c|c|c|c|}
\hline \multirow[b]{2}{*}{ Measure } & \multicolumn{3}{|c|}{ Average Configured Score } & \multirow[b]{2}{*}{$\begin{array}{l}\text { Sample n, } \\
\text { No Cx / Cx }\end{array}$} & \multirow[b]{2}{*}{$\% \mathbf{C x}$} & \multirow[b]{2}{*}{ P-value } & \multirow[b]{2}{*}{$\begin{array}{r}\text { Signifi- } \\
\text { cance }\end{array}$} \\
\hline & No $\mathrm{Cx}$ & $\begin{array}{l}\text { Commis- } \\
\text { sioned }\end{array}$ & Delta & & & & \\
\hline \multicolumn{8}{|l|}{ HVAC Measures: } \\
\hline TstatDdBnd & 8.16 & 8.07 & -0.09 & $5 / 19$ & $79 \%$ & 0.4565 & \\
\hline EconoInt & 8.76 & 7.12 & -1.64 & $5 / 19$ & $79 \%$ & 0.2048 & \\
\hline TstatSetbk & 4.64 & 6.39 & +1.75 & $5 / 19$ & $79 \%$ & 0.1839 & $\sim$ \\
\hline AutoDamp & 0.00 & 5.00 & +5.00 & $2 / 8$ & $80 \%$ & 0.1010 & $\sim$ \\
\hline DCV & 10.00 & 10.00 & +0.00 & $2 / 15$ & $88 \%$ & $\mathrm{n} / \mathrm{a}$ & \\
\hline OptStart & 2.00 & 4.21 & +2.21 & $5 / 19$ & $79 \%$ & 0.1985 & $\sim$ \\
\hline Cx HVAC Overall & 5.74 & 6.87 & +1.13 & $24 / 99$ & $80 \%$ & 0.1270 & $\sim$ \\
\hline \multicolumn{8}{|l|}{ Lighting Measures: } \\
\hline OccSenLtg & 8.17 & 9.33 & +1.16 & $7 / 17$ & $71 \%$ & 0.0281 & * \\
\hline DayLtgCtl & 6.62 & 6.58 & -0.04 & $6 / 16$ & $73 \%$ & 0.5152 & \\
\hline ExtLtgCtl & 10.00 & 9.91 & -0.09 & $7 / 17$ & $71 \%$ & $\mathrm{n} / \mathrm{a}^{\ddagger}$ & \\
\hline IntLtgCtl & 8.17 & 8.99 & +0.82 & $6 / 17$ & $74 \%$ & 0.5949 & \\
\hline Lighting Overall & 8.30 & 8.73 & +0.43 & $26 / 67$ & $72 \%$ & 0.2333 & \\
\hline
\end{tabular}

${ }^{\dagger}$ Formatting and tags to indicate significance level are shown in Table C.1.

‡Since measure was not shown in Table C.2 to be different from fully compliant, the impact of commissioning could not be determined.

\section{C.3.3 The Value of Commissioning}

There is a question of whether there is value to commissioning control measures in new buildings. Prior studies have shown such benefits (Mills et al. 2004); however a specific analysis of code-required controls has not been undertaken. While the caveats previously discussed do apply, and the results cannot be considered a definitive or exact projection of avoided lost savings due to commissioning, it is thought beneficial to look at the difference between commissioned and non-commissioned buildings. 
During the field study, investigators looked for evidence of commissioning and rated each building overall as commissioned or not separately for HVAC and lighting measures. To estimate energy cost savings benefits from commissioning, the lost savings by building was summed for measures that were found to be significantly impacted by commissioning. The four measures showing a significant difference are shown in Table C.7 and include thermostat setback, automatic damper, optimum start, and occupancy senor lighting control. These measures appear in all buildings in the field study. The results for the commissioned and not commissioned buildings were averaged on a per thousand square feet per year basis as shown in Table C.8. On an average lost energy cost basis, the results indicate that commissioning provides an energy savings benefit overall of $\$ 103$ per thousand square feet per year or $\$ 1,301$ on a lifecycle cost basis over 15 years. It should be noted that these savings are only for the four measures found to have a significant score difference in this study. A larger sample with more uncommissioned buildings may find larger potential savings per square foot for commissioning than was found here.

Table C.8. Average Impact of Commissioning on Lost Energy Savings

\begin{tabular}{lrrrr}
\hline Lost $\$$ /thousand $\mathbf{f t}^{2}$-yr & Lighting & HVAC & Total Annual & 15 Year PV \\
\hline Average with Commissioning & $\$ 5.26$ & $\$ 87$ & $\$ 93$ & $\$ 1,169$ \\
Average without Commissioning & $\$ 13.63$ & $\$ 182$ & $\$ 196$ & $\$ 2,469$ \\
Commissioning Benefit & $\$ 8.36$ & $\$ 95$ & $\$ 103$ & $\$ 1,301$ \\
\hline
\end{tabular}

\section{C.4 References}

Mann, H. B. and D.R. Whitney. 1947. On a Test of Whether one of Two Random Variables is Stochastically Larger than the Other. Ann. Math. Statist. 18 (1947), no. 1, 50-60. doi:10.1214/aoms/1177730491. http://projecteuclid.org/euclid.aoms/1177730491.

Mills E, H Friedman, T Powell, N Bourassa, D Claridge, T Haasl, and MA Piette. 2004. The CostEffectiveness of Commercial-Buildings Commissioning: A Meta-Analysis of Energy and Non-Energy Impacts in Existing Buildings and New Construction in the United States. Report 56637, Lawrence Berkeley National Laboratory, Berkeley, CA. http://evanmills.lbl.gov/pubs/pdf/cx-costs-benefits.pdf

Robinson, Andrew. 2016. “R Package 'equivalence'.” Accessed October 31, 2016 at: https://cran.r-project.org/web/packages/equivalence/equivalence.pdf

Siegel, S. and N. J. Castellan. 1988. Non Parametric Statistics for the Behavioural Sciences. MacGraw Hill International., New York. pp 213-214. 


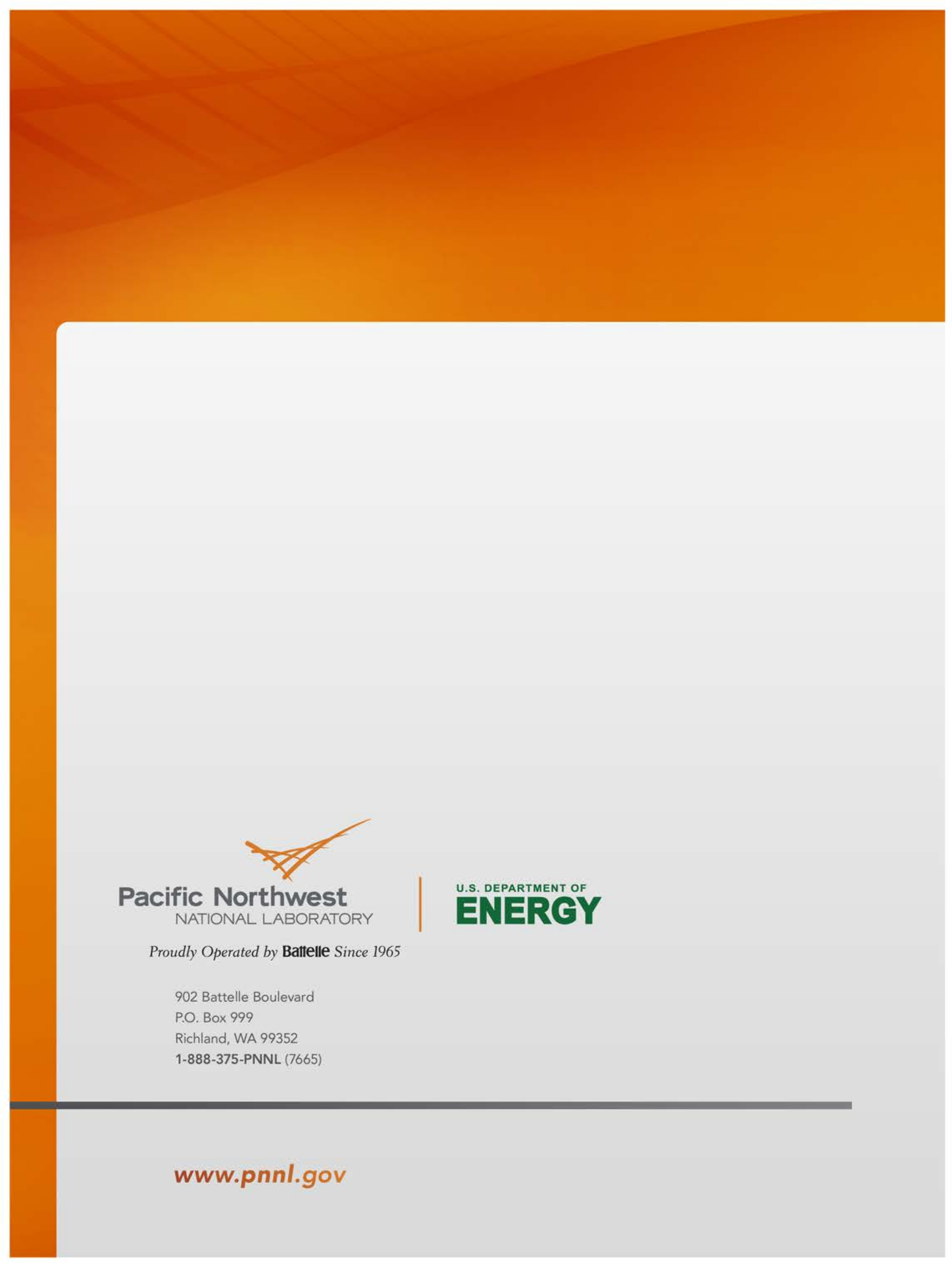

